\title{
AGREGAÇÃO DE SERVIĢOS: O SISTEMA PRODUTO-SERVIÇO EM UMA ABORDAGEM DINÂMICA
}

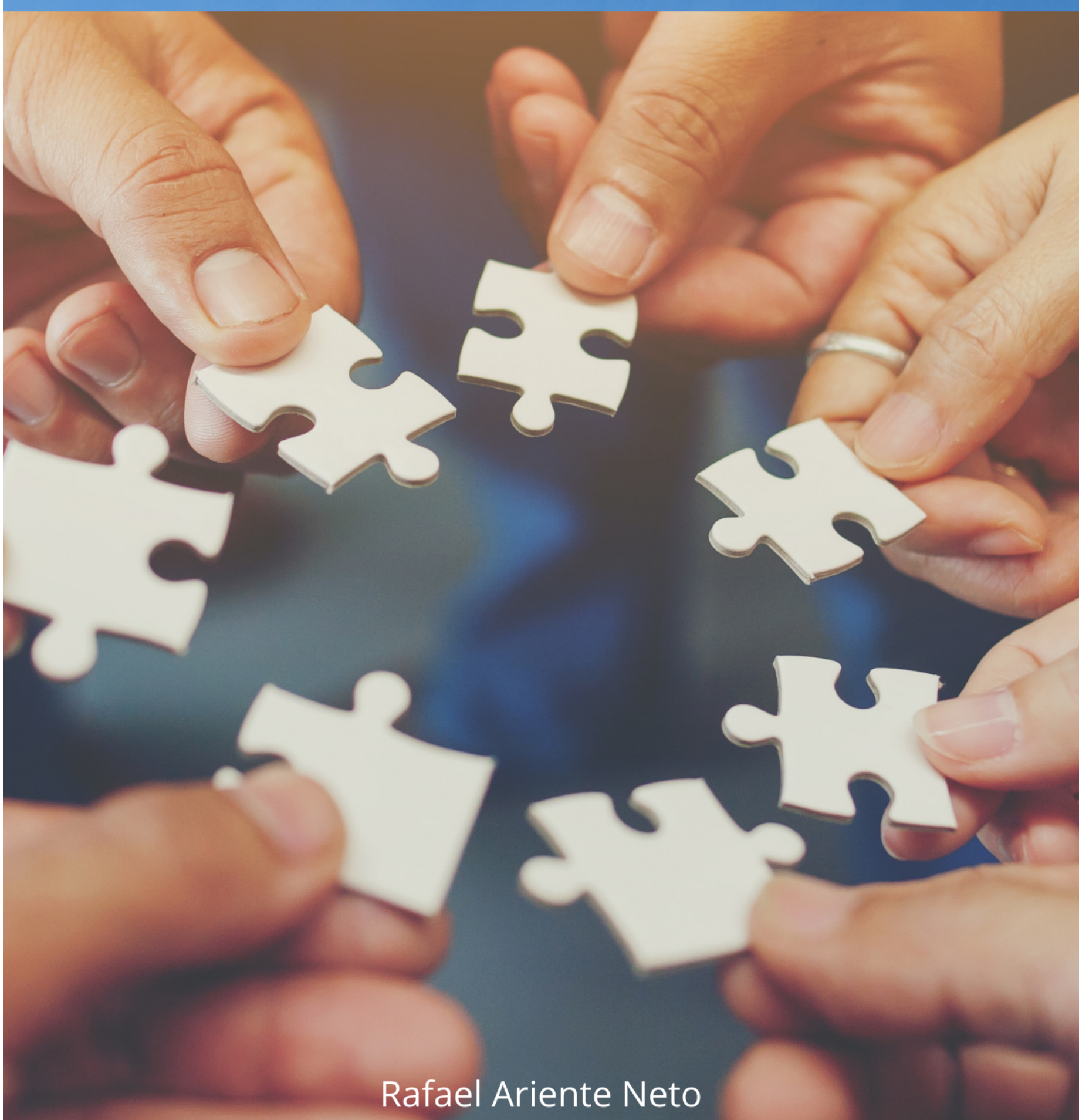


Rafael Ariente Neto

AGREGAÇÃO DE SERVIÇOS: O SISTEMA PRODUTO-SERVIÇO EM UMA ABORDAGEM DINÂMICA

$1^{\text {a }}$ ed.

Piracanjuba-GO

Editora Conhecimento Livre

Piracanjuba-GO 
$1^{\mathrm{a}} \mathrm{ed}$

\section{Dados Internacionais de Catalogação na Publicação (CIP)}

Ariente Neto, Rafael

A689A AGREGAÇÃO DE SERVIÇOS: O SISTEMA PRODUTO-SERVIÇO EM UMA

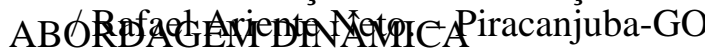

Editora Conhecimento Livre, 2022

136 f.: il

DOI: $10.37423 / 2022 . e d c 1431$

ISBN: 978-65-5367-046-4

Modo de acesso: World Wide Web

Incluir Bibliografia

1. sistema-produto-serviço 2. dinâmica-de-sistemas 3. diretrizes-de-desenvolvimento I. Ariente

Neto, Rafael II. Título

CDU: 620

https://doi.org/10.37423/2022.edc1431

O conteúdo dos artigos e sua correção ortográfica são de responsabilidade exclusiva dos seus respectivos autores. 


\title{
EDITORA CONHECIMENTO LIVRE
}

\section{Corpo Editorial}

\author{
Dr. João Luís Ribeiro Ulhôa \\ Dra. Eyde Cristianne Saraiva-Bonatto \\ MSc. Frederico Celestino Barbosa \\ MSc. Carlos Eduardo de Oliveira Gontijo \\ MSc. Plínio Ferreira Pires
}


AGREGAÇÃO DE SERVIÇOS: O SISTEMA PRODUTO-SERVIÇO EM UMA ABORDAGEM DINÂMICA

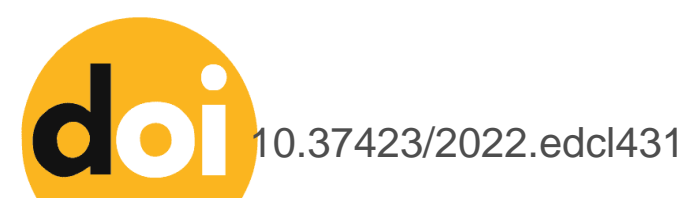

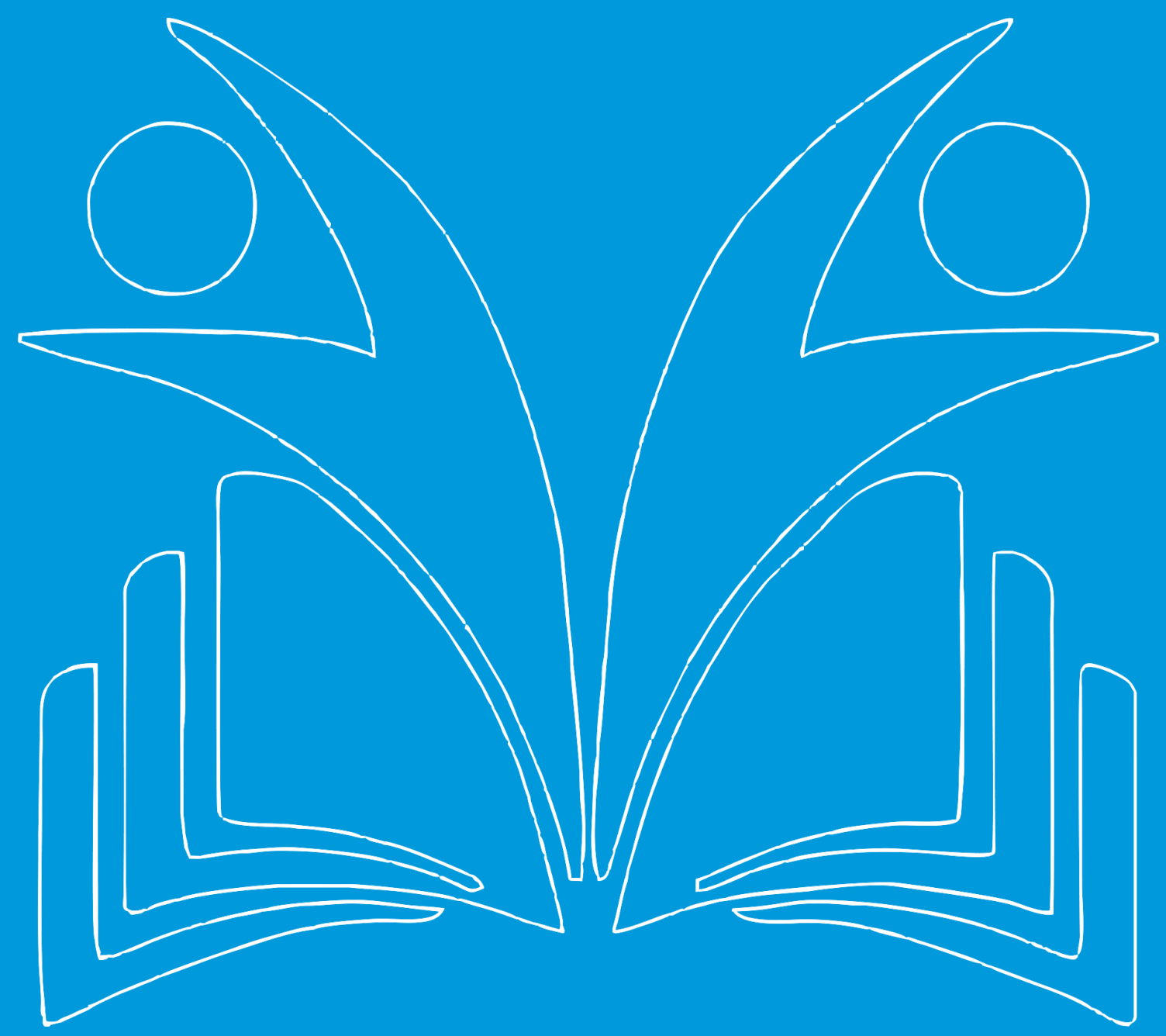




\section{AGRADECIMENTOS}

Creio que minha própria condição como ser humano limite a capacidade de transcrever meus sentimentos, entre eles o de gratidão. Essas palavras permitem, ao máximo, oferecer um sinal de tal sentimento a essas pessoas que convivi neste período.

Antes e acima de tudo agradeço a Deus.

Agradeço imensamente ao professor orientador de minha pesquisa de mestrado Sr. Dr. Fernando Antônio Forcellini, pelo conhecimento repassado e, sobretudo, pelos valiosos conselhos e imensa compreensão e paciência.

Esse sentimento também se estende a todos os professores, tanto do programa PosMEC como também do programa PPGEP com os quais tive a honra e privilégio de aprender.

Sou imensamente grato aos meus colegas e companheiros de jornada, em especial aos integrantes da equipe GEPP.

Agradeço também aos amigos e familiares que de forma direta ou indireta contribuíram com essa etapa da jornada.

Agradeço ao amigo Fabrício pelas valiosas conversas acerca do pensamento sistêmico.

Sou grato também aos meus professores da UNOESC que me concederam sua confiança e indicação para viabilizar meu ingresso no programa de pós-graduação.

Agradeço em especial ao professor que considero um grande amigo e tenho enorme respeito e admiração Sr. Sergio Marquezi. Meras palavras jamais conseguiriam expressar tamanha gratidão.

Agradeço também à $\mathrm{CNPq}$ pelo apoio financeiro ao Programa de Pós-graduação em Engenharia Mecânica da Universidade Federal de Santa Catarina e, consequentemente, à realização da pesquisa.

Também agradeço de antemão às pessoas que dedicarem o seu tempo para apreciar este trabalho. Que Ihes seja útil!

O meu "muito obrigado" a todos! 


\section{PREFÁCIO}

No início do período em que realizei o mestrado, quando tudo me era novo, fui apresentado a conteúdos. O primeiro consiste nos serviços. Para quem estava habituado a tratar apenas os bens tangíveis como seu objeto de atuação, a consideração dos serviços ampliou imensamente meu horizonte de possibilidades. A grande área de serviços é um universo que considero extremamente válido de ser abordado por todo o engenheiro.

O segundo foi o método da Dinâmica de Sistemas. Essa abordagem me permitiu olhar para as situações de modo totalmente diferente. Depois de conhecer a Dinâmica de Sistemas passei a aplicá-la em todas as pesquisas que realizei. Mais que isso, passei a ver as diversas situações do dia-a-dia, tanto em termos profissionais quanto na minha vida corriqueira, pela ótica que ela oferece. Simplesmente mudou minha forma de ver o mundo.

Esse livro abrange os dois conteúdos. Aqui falo sobre como os serviços podem estar mais próximos dos engenheiros de produtos do que eles mesmos imaginam. $E$, faço isso estabelecendo uma análise toda pautada pela ótica, ferramentas e técnicas da Dinâmica de Sistemas; na qual tenho a oportunidade de apresentá-la e discorrer a respeito.

Espero, sinceramente, que este livro instigue quem o consultar. Desejo uma ótima leitura. 


\section{LISTA DE FIGURAS}

Figura 1 - Panoramas: cenário convencional e cenário com o PSS................................... 14

Figura 2 - Processo decisório (a) sem aprendizagem e (b) apoiado pela DS...................... 21

Figura 3 - Paradigma da Dinâmica dos Sistemas....................................................... 22

Figura 4- Estruturação da análise pela Dinâmica de Sistemas............................................24

Figura 5- Representação gráfica do "ciclo de realimentação positivo" ................................. 28

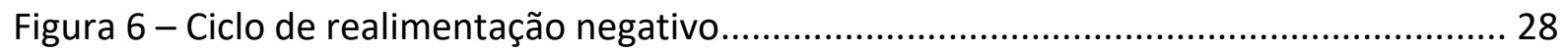

Figura 7 - Linguagem de Fluxo e Estoques para a modelagem estrutural............................. 30

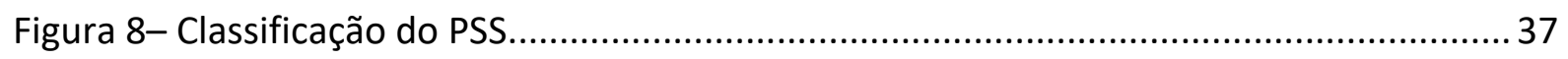

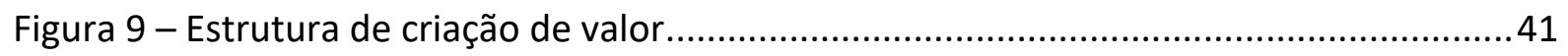

Figura 10 - Desdobramento do ciclo de vida do produto conforme o ponto de vista dos

Stakeholders.

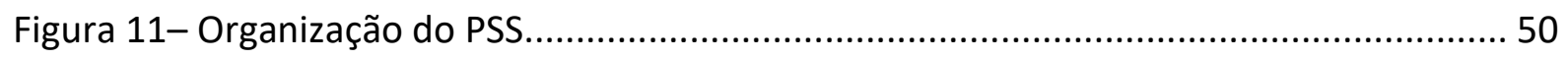

Figura 12 - Influência do conteúdo e dos canais de serviço na satisfação do receptor......... 52

Figura 13 - Processo de transformação da informação no desenvolvimento do PSS............. 53

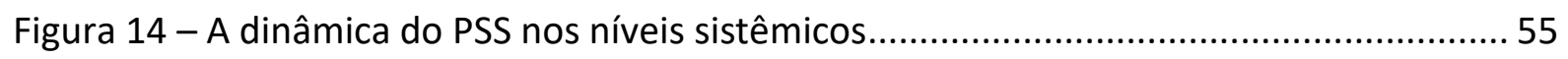

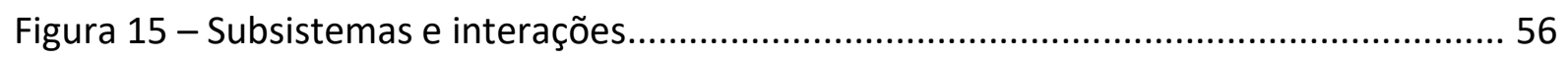

Figura 16 - Estrutura de referência para a condução da modelagem.................................. 62

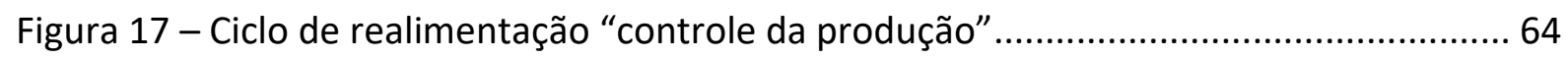

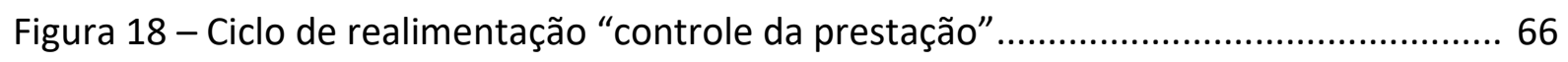

Figura 19 - Diagrama de causalidade (descrição do contexto)..........................................69

Figura 20 - Diagrama de fluxo e estoque do subsistema de produção................................. 73

Figura 21 - Diagrama de fluxo e estoque do subsistema de prestação................................ 75

Figura 22 - Diagrama de fluxo e estoque referente à qualidade percebida (bem tangível)... 76

Figura 23 - Diagrama de fluxo e estoque referente à qualidade percebida (serviços).......... 77 
Figura 24 - Ilustração pictórica do caso de referência. 80

Figura 25- Representação genérica de um sistem. .82

Figura 26 - Esboço do desempenho dinâmico da entrega de valor .85

Figura 27 - Condição favorável: "trabalho em processo". 87

Figura 28 - Condição favorável: "artefatos disponíveis" 87

Figura 29 - Condição favorável: taxas (subsistema de produção). 88

Figura 30 - Condição favorável: "consumidores em processo" 89

Figura 31 - Condição favorável: "consumidores processados". 90

Figura 32 - Condição desfavorável (bem tangível): “expectativa e percepção da qualidade” 91

Figura 33 - Condição desfavorável (bem tangível): "trabalho em processo". 92

Figura 34 - Condição desfavorável (bem tangível): "artefatos disponíveis" 93

Figura 35 - Condição desfavorável (bem tangível): "consumidores em processo" .94

Figura 36 - Condição desfavorável (bem tangível): "consumidores processados" .95

Figura 37 - Condição desfavorável (bem tangível): "trabalho em processo" para TeC=2sem. .96

Figura 38 - Condição desfavorável (bem tangível): "trabalho em processo" para TeC=1sem.

Figura 39 - Condição desfavorável (serviço): "expectativa e percepção da qualidade" .... 98

Figura 40 - Condição desfavorável (serviço): "artefatos disponíveis". 99

Figura 41 - Condição desfavorável: "consumidores em espera". .100

Figura 42 - Condição desfavorável (serviço): “consumidores em processo" 100

Figura 43 - Condição desfavorável (serviço): "consumidores processados". 101

Figura 44 - Condição desfavorável (serviço): ação das "perdas por espera"..... 102

Figura 45 - Condição desfavorável (serviço): "consumidores processados" com e sem perdas. 102 
Figura 46 - Condição desfavorável (serviço): "consumidores processados" com e sem

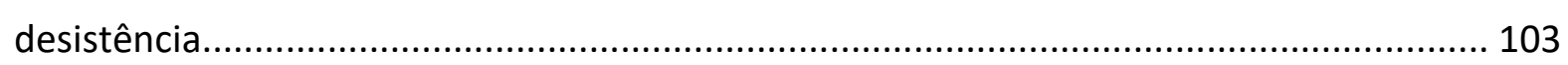

Figura 47 - Condição desfavorável (serviço): Intervenção TP............................................105 


\section{LISTA DE QUADROS}

Quadro 1 - Relação de técnicas e ferramentas utilizadas na modelagem PSS...................... 17

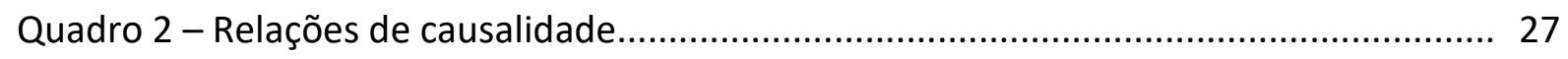

Quadro 3 - Definições do conceito de Sistema Produto-Serviço..................................... 33

Quadro 4 - Classificação de iniciativas PSS na indústria automotiva.................................. 38

Quadro 5 - Portfólio bibliográfico de base para a análise............................................. 43

Quadro 6 - Principais influências na interação entre os subsistemas.................................. 59

Quadro 7 - Classificação dos principais fatores do modelo............................................... 83 


\section{Sumário}

1 INTRODUÇÃO.

2 A MODELAGEM E A DINÂMICA DE SISTEMA

2.1 CONTRIBUIÇõES DOS MODELOS DE DINÂMICA DE SISTEMAS..

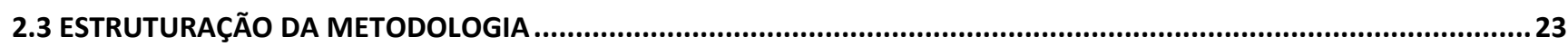

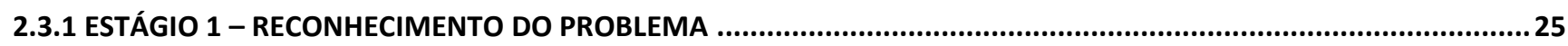

2.3.2 ESTÁGIO 2 - COMPREENSÃO DO PROBLEMA E DESCRIÇÃO DO SISTEMA (MODELAGEM QUALITATIVA).................25

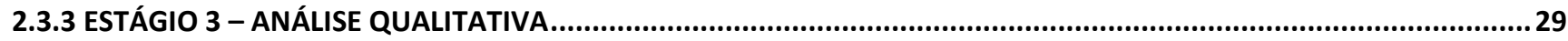

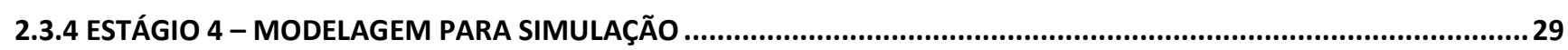

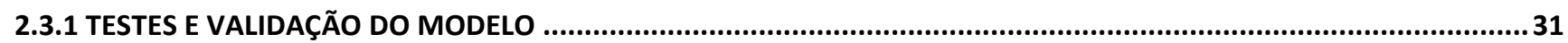

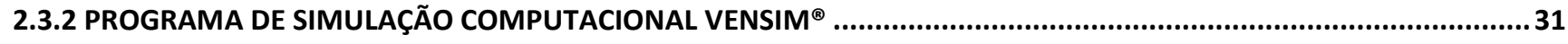

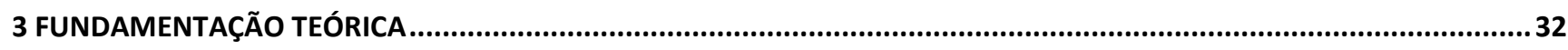

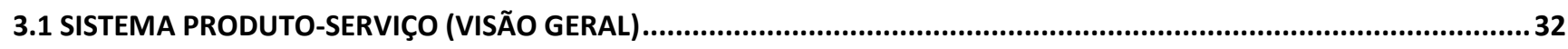

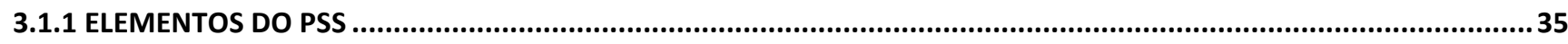

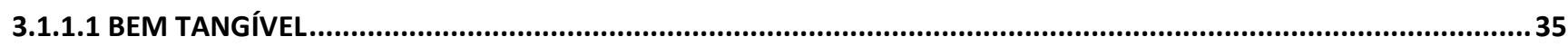

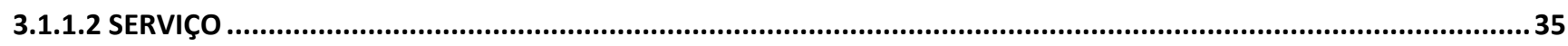

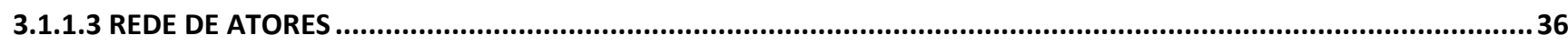

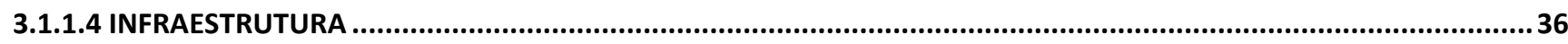

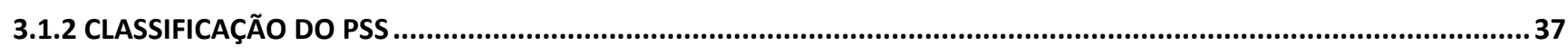

3.1.3 VALOR NO PSS

3.2 CARACTERIZAÇÃO DO PSS PARA A ANÁLISE (FUNDAMENTAÇÃo TEÓRICA ESPECÍFICA) ..........................................42

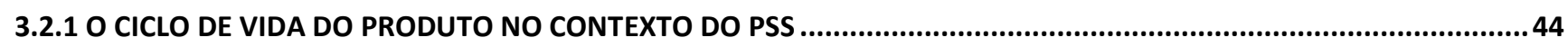

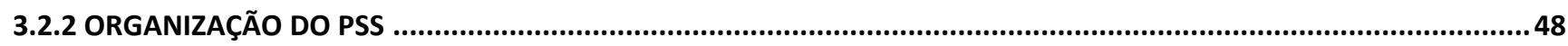

3.2.3 ASSOCIAÇÃO ENTRE OS ELEMENTOS DE BEM TANGÍVEL E SERVIÇO ..................................................................51

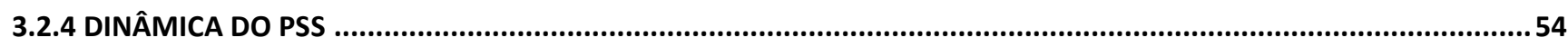

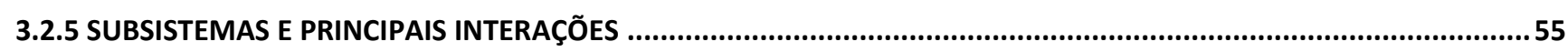

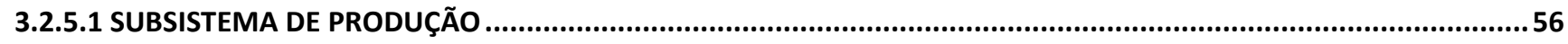

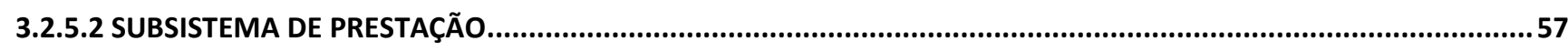




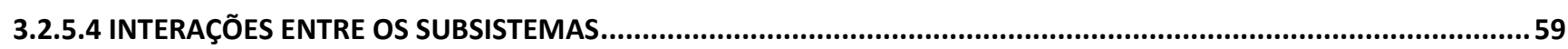

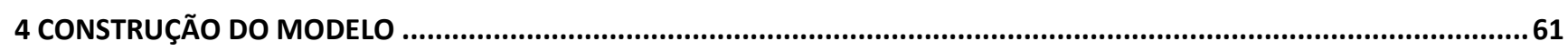

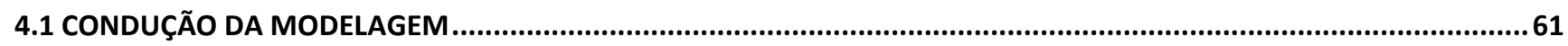

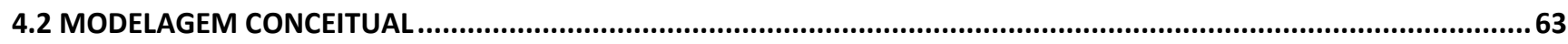

4.2.1 CICLO DE REALIMENTAÇÃO “CONTROLE DA PRODUÇÃO” ............................................................................63

4.2.2 CICLO dE REALIMENTAÇÃO “CONTROLE DA PRESTAÇÃO” ............................................................................65

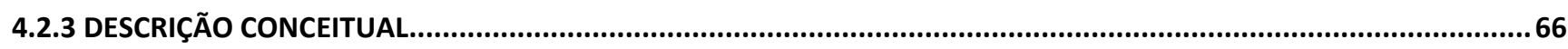

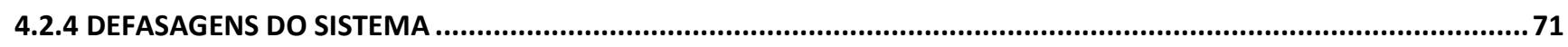

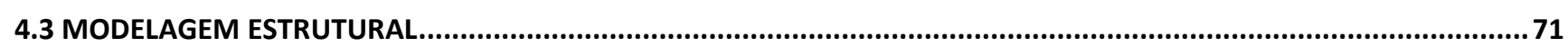

4.3.1 FLUXOS E ESTOQUES NO SUBSISTEMA DE PRODUÇÃO..............................................................................72

4.3.2 FLUXOS E ESTOQUES NO SUBSISTEMA DE PRESTAÇÃO .............................................................................74

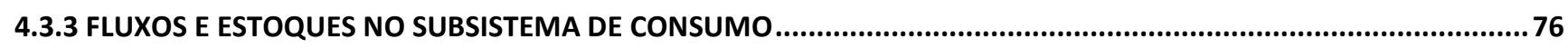

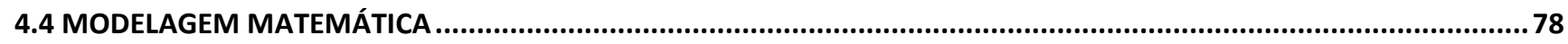

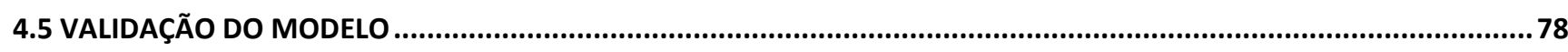

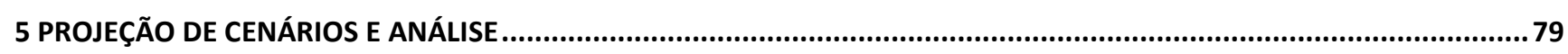

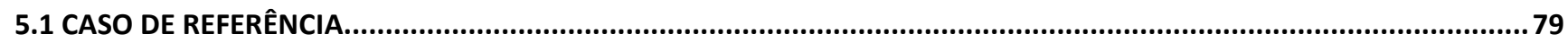

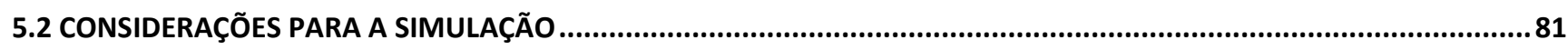

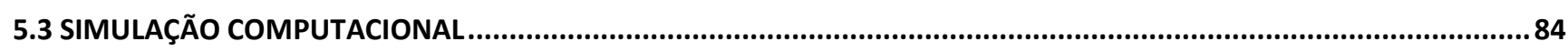

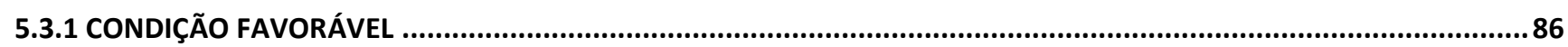

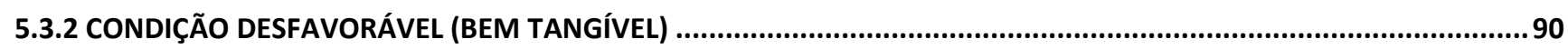

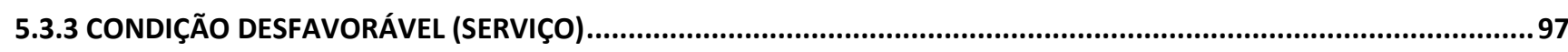

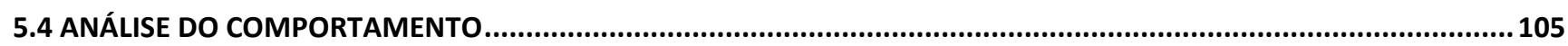

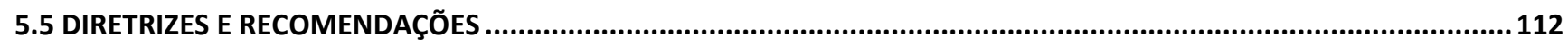

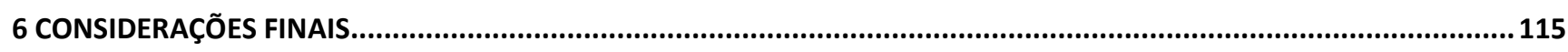

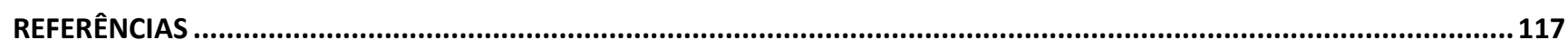

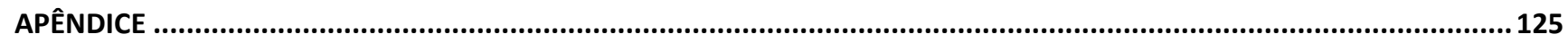

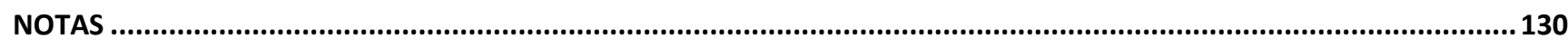




\section{INTRODUÇÃO}

O mercado brasileiro, entre 2011 e 2012, teve a participação da indústria de transformação no PIB nacional reduzida de $23,5 \%$ para $22,3 \%^{1}$. São vários os aspectos apontados como fatores contribuintes para esta redução. Dentre estes está a produção em massa (grandes quantidades em um tempo reduzido) que propicia, por um lado, a redução dos custos de produção devido às economias de escala, entre outros atrativos. No entanto, por outro lado a produção em massa conduz ao estabelecimento de uma concorrência baseada em preços, impondo tal condição aos demais fabricantes, algumas vezes incapazes de acompanhá-la. Essa concorrência ainda é intensificada frente ao custo consideravelmente menor da mão-de-obra em determinados países, além do fenômeno da "comoditização dos bens"2.

Frente a esta perspectiva são apontados como alguns dos desafios a serem enfrentadas no mercado interno brasileiro pelas indústrias de transformação: a intensificação da sua progressão tecnológica, o enfrentamento da acirrada concorrência internacional nos mercados domésticos e externos, o combate aos efeitos da "guerra cambial" e das incertezas do cenário internacional (BRASIL MAIOR, [2011]). Mas ainda, como reflexo das demandas sustentáveis é cada vez mais emergente da sociedade civil a cobrança às empresas por contribuições significativas no tratamento de questões sustentáveis (KIMITA; SHIMOMURA; ARAI, 2009). Isto pode, inclusive, ser determinante para a aceitação da

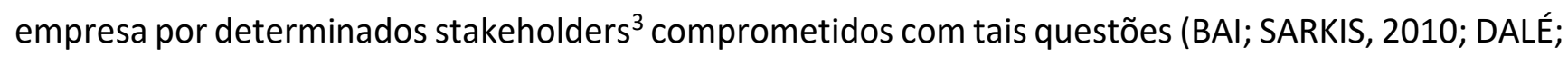
ROLDAN; HANSEN, 2011). Juntamente, regulamentações como a Política Nacional de Resíduos Sólidos (ainda referente ao cenário brasileiro) tornam muitas demandas sustentáveis como um requisito obrigatório e, como tal, determinante para a atuação das organizações no mercado.

Nesse sentido e conforme a abordagem sistêmica ${ }^{4}$ a unidade de negócio é influenciada pelos seus ambientes mediatos e imediatos (SENGE; STERMAN, 1992; BUI; BARUCH, 2010) e necessita adaptarse a estes ambientes para garantir sua "sobrevivência". As organizações constituem, nesta ótica, sistemas abertos $^{5}$ apresentando as características de adaptabilidade, controle ou regulação, e aprendizagem. A adaptabilidade atribui ao sistema a propriedade de ajustar-se a evolução do meio. Tal propriedade é viabilizada justamente em função do sistema aberto ser sensível ao seu ambiente, identificando sua evolução e respondendo a esta por meio de sua própria evolução, a adaptação. 0 controle ou regulação representam os meios pelos quais os organismos viabilizam sua adaptabilidade. O controle é responsável pela identificação da amplitude das mudanças do meio e coordenar a amplitude das mudanças necessárias para prover a adaptabilidade; é a forma de definir o quanto 
mudar. Por fim, a aprendizagem é a capacidade de cumular os efeitos passados da adaptação. É possível observar adaptação sem aprendizagem, porém, esta se apresenta de forma mais lenta comprometendo a sobrevivência do organismo. Ou seja, os sistemas abertos são caracterizados pelo dinamismo e complexidade inerente ao seu comportamento.

Contudo, as inovações atribuídas aos $\operatorname{produtos}^{6}$ das empresas manufatureiras buscando a continuidade da sua atuação e, juntamente, contribuindo ao desenvolvimento sustentável podem ser classificadas no sentido de uma melhoria tecnológica incremental (VEZZOLI, 2007). Assim, nessa classificação tem-se: o melhoramento ou reprojeto do produto ou do processo, a inovação funcional e a inovação no sistema (VEZZOLI, 2007). Quanto ao melhoramento ou reprojeto do produto a área de desenvolvimento, no que se refere aos métodos e ferramentas, tem-se buscado agregar práticas de desenvolvimento que atendam as exigências ambientais do desenvolvimento sustentável. Um exemplo consiste no emprego de ferramentas de projeto como o DFE (Design For Environment). Também se prestam a tal objetivo o Design For Upgrade que visa "fechar" o ciclo de vida dos produtos, aproveitando- os ao final de sua vida útil, e o Modular Design no qual o produto é concebido sendo constituído por componentes menores, podendo alguns destes, ou todos, serem empregados em diferentes sistemas na obtenção de múltiplas funcionalidades. Referente aos processos, as abordagens de avaliação ou análise do ciclo de vida auxiliam a identificar as possibilidades de intervenção ao longo do ciclo de vida e as opções de melhora neste. Buscam-se processos produtivos mais limpos, melhores tecnologias de processamentos de resíduos e a própria evolução da tecnologia empregada como maneira de reduzir a energia consumida. Já a inovação funcional envolve a exploração de formas novas e inovadoras para fornecer a funcionalidade requerida. Nesta exploração busca-se a realização da função desejada com uma configuração ou uma tecnologia menos exigente em termos de consumo de materiais, energia para funcionamento, entre outros.

Estas formas de inovação, no entanto, objetivam atingir padrões sustentáveis melhorando o desempenho ambiental por unidade de artefatos físicos, não assegurando, porém, a redução do impacto ambiental no caso de um crescente consumo global ou de padrões de uso mais intensos (WILLIAMS, 2007). Para tal, a inovação no sistema, considerando o sistema amplamente pode implicar em mudanças significativas na dinâmica do mercado. Dessa forma, pela inovação no sistema os padrões socioculturais que se refletem nos sistemas de produção e consumo atuais podem ser conduzidos a uma dinâmica coerente ao desenvolvimento sustentável e que, juntamente, sustente a 
economia. Um dos meios para viabilizar a inovação no sistema está no Sistema Produto-Serviço (Product-Service System ou PSS).

O PSS consiste em um conjunto comercial de produtos (como bens tangíveis) e serviços, rede de atores e infraestrutura de apoio objetivando a competitividade, a satisfação das necessidades dos clientes e um menor impacto ambiental (GOEDKOOP et al., 1999; MONT, 2001). Diferentemente, por exemplo, da venda convencional de bens em que a entrega de valor ${ }^{7}$ se concentra na sua venda/compra, o PSS sob a forma de um sistema ${ }^{8}$ estende essa entrega de valor ao longo do ciclo de vida por meio da agregação de serviços. A Figura 1 ilustra essas duas perspectivas em um ciclo de vida representado segundo o ponto de vista do fabricante. No cenário convencional após a aquisição do bem, quando ocorre o contato do consumidor com o fabricante, o consumidor assume a posse de tal. Assim, tornase responsável por este nas etapas subsequente como o "uso", a "manutenção", e até o seu "descarte". Já em um cenário com PSS o bem tangível surge agregado a serviços (parte intangível do valor entregue). Esses serviços são orientados ao ciclo de vida de forma a complementar determinadas etapas. A viabilização do PSS, dessa forma, engloba a atuação de stakeholders específicos responsáveis pela prestação dos serviços. Além destes, como também é representado na Figura 1, o consumidor final possui um papel extremamente relevante para o sucesso da implementação de um PSS. Como a prestação dos serviços, muitas vezes, ocorre em contato com o consumidor, muitas questões gerenciais a serem observadas surgem deste contato. Além de que, muitas vezes, a mudança de um cenário baseada na venda de bens isoladamente para uma nova dinâmica somente é possível se acompanhada da mudança dos hábitos de consumo (WONG, 2004). 
Figura 1 - Panoramas: cenário convencional e cenário com o PSS

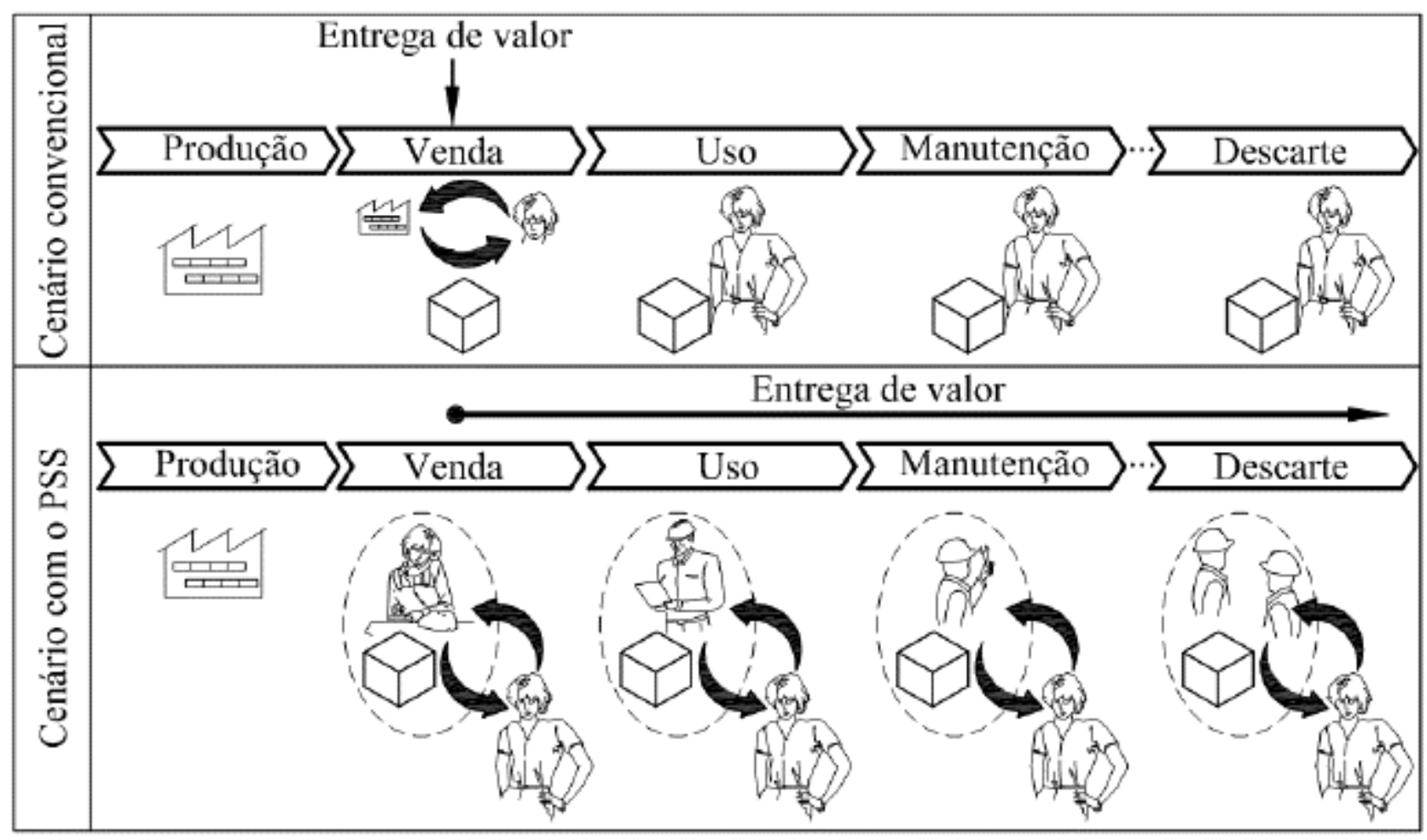

Fonte: o autor.

O Sistema Produto-Serviço é visto com potencial para prover tanto à competitividade almejada pelos fabricantes ao estender o valor entregue em relação à estratégia convencional, sobretudo em momentos de crise, quanto às questões sustentáveis demandadas a estes (TUKKER, 2004; BIANCHI et al., 2009; KIMITA; SHIMOMURA; ARAI, 2009). A

constituição e a dinâmica do PSS proporcionam a diversificação do seu valor oferecido, podendo assim atender a necessidades específicas dos consumidores. Ademais, o diferencia da estratégia convencional evitando a constante redução do custo de produção e dos problemas que acarretam desta redução. Também, a associação entre bens tangíveis e serviços com suporte dos demais elementos possibilita ao PSS o atendimento das necessidades dos consumidores oferecendo-Ihes a funcionalidade sem, necessariamente, atribuir-lhes a posse de tais bens (GOEDKOOP et al., 1999; EHRENFELD, 2001; MONT, 2001; MANZINI;

VEZOLLI, 2003). Essa característica (a desmaterialização) confere ao PSS a possibilidade de desconexão entre as atividades econômicas e os impactos ambientais (fundamentada na mudança de hábitos de consumo). 
Apesar dos benefícios atribuídos ao Sistema Produto-Serviço com o ingresso em um empreendimento PSS a responsabilidade do fabricante estende-se para além da venda do produto, abrangendo todo o ciclo de vida (PHUMBUA; TJAHJONO, 2011). Isto devido à influência dos demais elementos que compõem o sistema, inclusive dos stakeholders nos quais também se enquadram os consumidores finais e sua percepção do valor entregue pelo PSS, tal como, das condições do mercado em que se insere. Consequentemente os fabricantes assumem um elevado grau de risco ao integrar um empreendimento PSS, visto que o risco do investimento e da capacidade no PSS é superior ao dos negócios tradicionais (MANZINI; VEZOLLI, 2002; TUKKER; TISCHNER, 2006). Isto ainda se acentua pelo PSS se caracterizar como um sistema dinâmico ${ }^{9}$ no qual atuam estruturas de realimentação de informações, defasagens e não linearidades. A configuração de um sistema dinâmico sem o entendimento do seu comportamento está sujeita ao desencadeamento de eventos desfavoráveis em partes remotas do sistema (STERMAN, 2000).

Dessa maneira os processos de desenvolvimento do produto, sendo este integrante de um PSS (um elemento deste sistema), precisam considerar as influências das características e dinâmicas do ciclo de vida em que se insere e dos serviços associados a este produto (AURICH et al., 2009). No âmbito do projeto do bem tangível (ainda em suas fases iniciais) as metodologias, métodos e ferramentas com as quais os fabricantes contam podem intervir em aspectos específicos do ciclo de vida; podendo, dessa forma, induzir o sistema para um comportamento desejável. Nesta perspectiva se enquadram, por exemplo, as abordagens DFX (Design For X10). Essas abordagens levam a decisões que se refletem na funcionalidade, geometria e propriedades do artefato influenciando, assim, no seu desempenho (ROZENFELD et al., 2006). No entanto, visto o exposto acerca das características de complexidade e dinamismo do PSS, uma condição fundamental para o desenvolvimento de um produto adequado ao sistema que integra consiste na compreensão do comportamento ao longo do tempo do sistema. Ou seja, essa compreensão é fundamental para a indução de um comportamento desejável ao sistema pela intervenção no projeto do produto.

A determinação de uma solução para um problema técnico engloba o atendimento aos objetivos e às condicionantes restritivas (PAHL et al., 2005). Nesse sentido, propriamente o atendimento à função técnica é um dos objetivos da solução, porém ainda acompanhado de objetivos de natureza financeira, estética, ambiental, de segurança, entre outras possíveis considerações. Esses outros objetivos podem ter origem em questões estratégicas, éticas, ou mesmo por imposição de normas, como no caso de normas de segurança. 
Contudo, além da função, funcionalidade, configuração e de suas inter-relações a solução técnica ainda tem que satisfazer as condicionantes (PAHL et al., 2005). Essas condicionantes consistem nas diversas imposições associadas à obtenção dos objetivos da solução e, dessa maneira, referente a esses objetivos. De uma maneira geral, as condicionantes são consideradas ao longo do processo de projeto, em coerência com o grau de materialização exigido em cada etapa desse processo (PAHL et al., 2005). Isto se estende desde as condições que influenciam o gerenciamento do projeto até o estabelecimento de grandezas construtivas. Podem, portanto, ter diferentes origens como as limitações do processo de desenvolvimento ou produtivo, a disponibilidade para distribuição e demais questões logísticas, dentre outras. Nesse livro em específico são abordadas as principais condicionantes referentes ao comportamento dinâmico da agregação de um módulo de serviço ao bem tangível em um contexto definido.

Dentro dos princípios metódicos de projeto e realização de tarefas as "diretrizes" auxiliam a dar ênfase às respectivas condicionantes e, principalmente, alicerçam as regras básicas (PAHL et al., 2005). Nesse contexto as diretrizes ajudam na aplicação dos conhecimentos técnicos, podendo originar requisitos voltados tanto para o controle quanto para a melhora ou estabelecimento de características particulares de um produto. Portanto, tais condicionantes serão abordadas de modo que, ao término da análise, sejam estabelecidas diretrizes para a orientação dos esforços de desenvolvimento do produto pela avaliação do comportamento da agregação de um módulo de serviço ao bem tangível no contexto do PSS.

Para o processo de avaliação do comportamento de tal agregação é construído um modelo que representa o contexto do PSS e utilizada a simulação para a prospecção de cenários. Esses cenários representam o comportamento de determinados indicadores do sistema ao longo de um horizonte temporal. Portanto, a avaliação tem base na análise e comparação dos cenários. O processo de modelagem é conduzido com as ferramentas e técnicas da abordagem da Dinâmica de Sistemas (DS).

\section{A MODELAGEM E A DINÂMICA DE SISTEMA}

Como as perspectivas de análise do Sistema Produto-Serviço são vastas, muitos poderiam ser os enfoques à criação de modelos e a seleção de métodos e ferramentas para este fim (MONT, 2002). Nesse sentido a investigação conduzida por Phumbua e Tjahjono (2011) relaciona 22 trabalhos que utilizam técnicas de modelagem e ferramentas nos diferentes aspectos relacionados ao PSS. Esses dados são dispostos no Quadro 1. 


\section{Quadro 1 - Relação de técnicas e ferramentas utilizadas na modelagem PSS}

\begin{tabular}{|c|c|c|}
\hline Referência & Técnica & Ferramenta \\
\hline $\begin{array}{l}\text { Fujimoto } \text { et al. } \\
\qquad(2003)\end{array}$ & Simulação de eventos discretos & Simulador de ciclo de vida \\
\hline Komoto et al. (2005) & $\begin{array}{l}\text { Simulação de eventos discretos / algoritmo } \\
\text { genético }\end{array}$ & Simulador de ciclo de vida \\
\hline $\begin{array}{c}\text { Aurich, Fuchs e } \\
\text { Wagenknecht (2006) }\end{array}$ & $\begin{array}{l}\text { Método orientado ao ciclo de vida; } \\
\text { Modularização de processo }\end{array}$ & $\begin{array}{l}\text { UML } 2.0 \\
\text { Modelo de processo produtivo } \\
\text { integrado (IPMM) }\end{array}$ \\
\hline Morelli (2006) & $\begin{array}{l}\text { Análise de caso e cenários; } \\
\text { Service blueprinting; } \\
\text { IDEF0 }\end{array}$ & \\
\hline $\begin{array}{c}\text { Buxton, Farr e } \\
\text { Mccarthy (2006) }\end{array}$ & Simulação baseada em agentes & AnyLogic \\
\hline $\begin{array}{l}\text { Sakao e Shimomura } \\
\qquad(2005)\end{array}$ & $\begin{array}{l}\text { Desdobramento da função qualidade (QFD); } \\
\text { Processo de hierarquia analítica }\end{array}$ & $\begin{array}{l}\text { Service Explorer; } \\
\text { JAVA2 SDK, Std edition 1.4.1; } \\
\text { XML } 1.0\end{array}$ \\
\hline $\begin{array}{l}\text { Maussang et al. } \\
\text { (2007) }\end{array}$ & $\begin{array}{l}\text { Análise funcional; } \\
\text { Projeto de valor por agentes }\end{array}$ & \\
\hline $\begin{array}{c}\text { Komoto e Tomiyama } \\
\text { (2008) }\end{array}$ & Modelagem de serviços & CAD e simulador de ciclo de vida \\
\hline $\begin{array}{l}\text { Abramovici et al. } \\
\text { (2009) }\end{array}$ & UML & \\
\hline Kim et al. (2009) & $\begin{array}{l}\text { Ontological representation; } \\
\text { Ciclo de modelagem de atividade - UML / OML }\end{array}$ & Protégé, com conversão para Jess \\
\hline Hara et al. (2009) & Service blueprinting & $\begin{array}{l}\text { Business Process Management } \\
\text { Notation }\end{array}$ \\
\hline Bianchi et al. (2009) & Dinâmica de Sistemas & \\
\hline Alonso-Rasgado, & Modelagem molecular; & Linguagem de programação geral \\
\hline $\begin{array}{c}\text { Thompson e } \\
\text { Elfström (2004) }\end{array}$ & $\begin{array}{l}\text { Service blueprinting; } \\
\text { Simulação de eventos discretos }\end{array}$ & \\
\hline $\begin{array}{c}\text { Hara, Arai e } \\
\text { Shimomura (2006) }\end{array}$ & $\begin{array}{l}\text { Petri net simulation; } \\
\text { QFD; } \\
\text { Processo de hierarquia analítica (DEMATEL); }\end{array}$ & $\begin{array}{l}\text { Service Explorer } \\
\text { CPN Tools }\end{array}$ \\
\hline Low et al. (2000) & TRIZ & \\
\hline $\begin{array}{l}\text { Muller e Blessing } \\
\qquad(2007)\end{array}$ & $\begin{array}{l}\text { Entidades de processamento; } \\
V \text {-model }\end{array}$ & \\
\hline $\begin{array}{c}\text { Schuh, Boos e } \\
\text { Kozielski (2009) }\end{array}$ & $\begin{array}{l}\text { Modelo orientado ao custo do ciclo de vida; } \\
\text { Custeio baseado em atividades }\end{array}$ & \\
\hline
\end{tabular}




\begin{tabular}{|c|l|l|}
\hline Morelli (2003) & $\begin{array}{l}\text { Análises de caso e funcional } \\
\text { Blueprint }\end{array}$ & \\
\hline Weber et al. (2004) & $\begin{array}{l}\text { Projeto/desenvolvimento voltado às propriedades } \\
\text { (PDD) }\end{array}$ & \\
\hline $\begin{array}{c}\text { Evans, Partidário e } \\
\text { Lambert (2007) }\end{array}$ & $\begin{array}{l}\text { Mapeamento de soluções; } \\
\text { Custeio do ciclo de vida }\end{array}$ & \\
\hline Jin e Liya (2008) & QFD com abordagem Fuzzy; & $\begin{array}{l}\text { Service blueprinting; } \\
\text { Advance sequential incidente; } \\
\text { Schuh e Gudergan de interdependências; } \\
\text { (2009) }\end{array}$ \\
\hline $\begin{array}{l}\text { Comparação por pares; } \\
\text { Abstração progressiva }\end{array}$ & \\
\hline
\end{tabular}

Fonte: adaptado de Phumbua e Tjahjono (2011), tradução do autor.

A partir desta relação, a modelagem em PSS pode ser segmentada em três categorias relativas ao objeto foco da modelagem: a categoria de modelagem voltada ao usuário, voltada ao produto-serviço e a categoria voltada ao sistema (PHUMBUA; TJAHJONO, 2011). Cada categoria requer, em função de suas particularidades, uma correspondência à estruturação e ao formalismo das técnicas de modelagem.

Assim, na primeira categoria, voltada ao usuário, são focadas não somente as necessidades dos mesmos, como aspectos referentes à interação do consumidor com o produto-serviço, a interação dos prestadores com o consumidor ou a própria interação entre usuários do sistema. Nesta categoria podem ser situadas as abordagens referentes ao modelamento de negócio e os diversos mapeamentos dirigidos à configuração da rede de envolvidos no sistema. Utilizaram-se comumente o método de modelagem "service blueprinting", "modelagem de cenários", as ferramentas implícitas na "engenharia de serviços" (flow model, scope model, view model), técnicas gráficas como a IDEF (Integration Definition Language) e mapeamentos (de fluxo de valor, atividades, entre outros).

A segunda categoria, que foca no próprio produto-serviço, está relacionada aos paradigmas de projeto. Aplicaram-se nas modelagens referentes a esta categoria as técnicas "teoria da solução inventiva de problemas (TRIZ)", "V-model", "desdobramento da função qualidade (QFD)" e "projeto/desenvolvimento voltado às propriedades (PDD)".

A terceira categoria é voltada ao sistema focando o auxílio aos projetistas e gerentes na compreensão dos impactos de suas atividades visando à melhoria do desempenho do sistema. Aborda questões de 
ordem tanto estratégicas quanto operacionais. Nesta categoria são empregadas três técnicas de modelagem: "eventos discretos", "dinâmica de sistemas" e "baseada em agentes".

Referente a esta terceira categoria a modelagem por "eventos discretos" considera os estados das variáveis do problema como variando em um conjunto discreto de valores no tempo. É utilizada na análise de sistemas de manufatura e análise de muitos aspectos relacionados ao ciclo de vida de produtos. Entretanto também vem sendo explorada na análise de funcionalidade em serviços (ALONSO-RASGADO; THOMPSON; ELFSTRÖM, 2004). Sua aplicação no PSS permite avaliar seu desempenho em função de ocorrência de eventos.

Já a simulação da interação entre agentes, ao invés de fluxos de processos, consiste em uma abordagem sensível a característica proposital de sistemas complexos. Pode ser empregado para analisar o comportamento dinâmico do mercado (considerando os agentes como as organizações) e avaliar o desempenho de agentes em contextos específicos (considerando, por exemplo, a avaliação do agente "engenheiro" no contexto de suas atribuições).

Por fim, a Dinâmica de Sistemas assim como a simulação baseada em agentes também encontra aplicações na análise de sistemas de manufatura e de aspectos do ciclo de vida de produtos. Contudo, pode ser empregada a qualquer tipo de sistemas quando o interesse é seu comportamento no tempo (COYLE, 1996). Assim, é utilizada para fundamentar decisões baseadas em longos horizontes de planejamento em contextos com alto nível de abstração. Seu principal diferencial e contribuição para a análise de sistemas complexos, como os sistemas organizacionais, está em uma versátil linguagem utilizada para simulação e projeção de cenários representativos dos efeitos dos ciclos de realimentação identificados no sistema. A Dinâmica de Sistemas aborda o comportamento do sistema como função de sua estrutura. Dessa forma, o foco recai nas relações temporais e não nos valores absolutos dos elementos. Essa é a característica que lhe permite analisar sistemas sócios técnicos em geral.

Dessa maneira, como o objetivo desta análise está relacionado à compreensão do comportamento de aspectos do PSS buscando sua visualização de forma temporal e como a DS é concordante com a abordagem sistêmica necessária, optou-se pela utilização da DS como instrumento de intervenção. Assim os modelos construídos no desenvolvimento desta análise vinculam-se a linguagem utilizada por esta metodologia. 


\subsection{CONTRIBUIÇÕES DOS MODELOS DE DINÂMICA DE SISTEMAS}

Quando os modelos mentais11 do gestor (ou equipe) que fornecem a interpretação da situação real (mundo real) não observam a estrutura de realimentação de informações, as estratégias, estruturas e regras de gestão que fundamentam as decisões impactam no objeto de gerenciamento de forma linear. O efeito acumulativo da realimentação de informação sempre presente em situações reais distancia o objetivo desejado pela decisão tomada dos efeitos provocados na situação real objeto da gestão. A Figura 2a mostra esta condição de gestão na qual pode ser visualizado que os modelos mentais não são atualizados por ciclos de realimentação.

A proposição de um modelo de Dinâmica de Sistema estabelece um processo de aprendizagem uma vez que identifica e estrutura os ciclos de realimentação atuantes. Como é mostrado na Figura $2 b$ os modelos mentais consideram estes ciclos pela interação com o modelo. Dessa forma, o modelo de Dinâmica de Sistemas estabelece um "mundo virtual” no qual as decisões podem ser testadas antes de serem aplicadas à situação real (mundo real). A constante atualização dos modelos mentais também pode, e deve gerar atualizações no próprio modelo da Dinâmica de Sistemas conforme a acentuação do entendimento do contexto.

Assim, a aplicação da Dinâmica de Sistemas (DS) no contexto desta análise contribui com o melhor entendimento da estrutura de ciclos de realimentação de informações que se fazem presentes e determinam o comportamento do PSS nos aspectos abordados. A proposição do modelo conceitual contribui com a identificação, sintetização, e organização das informações disponíveis na literatura vigente, e pela disponibilização do ponto de vista específico em que a análise foi desenvolvida. Dessa forma é disponibilizada aos gestores a referência qualitativa ao entendimento de como os subsistemas do PSS, em suas relações dinâmicas, interagem na criação e entrega de valor. Por fim, essa análise também contribui com a construção do modelo estrutural e matemático que disponibiliza aos gestores um "laboratório de aprendizagem" no qual as decisões referentes à intervenção nos fatores e relações do contexto abordado para o PSS possam ser testadas antes de aplicadas à situação real. 
Figura 2 - Processo decisório (a) sem aprendizagem e (b) apoiado pela DS

(a)

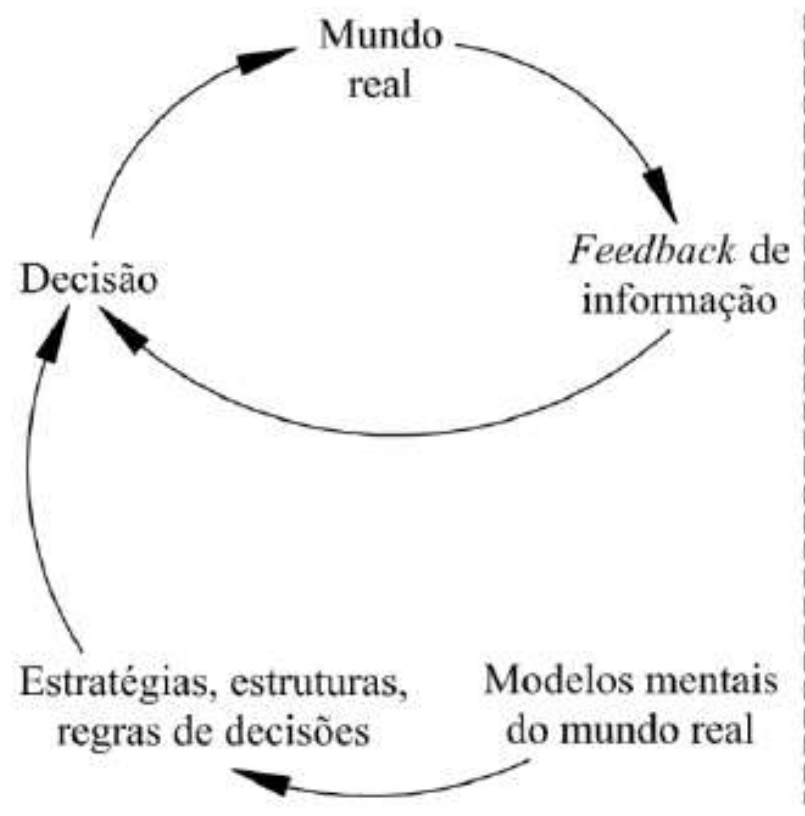

(b)

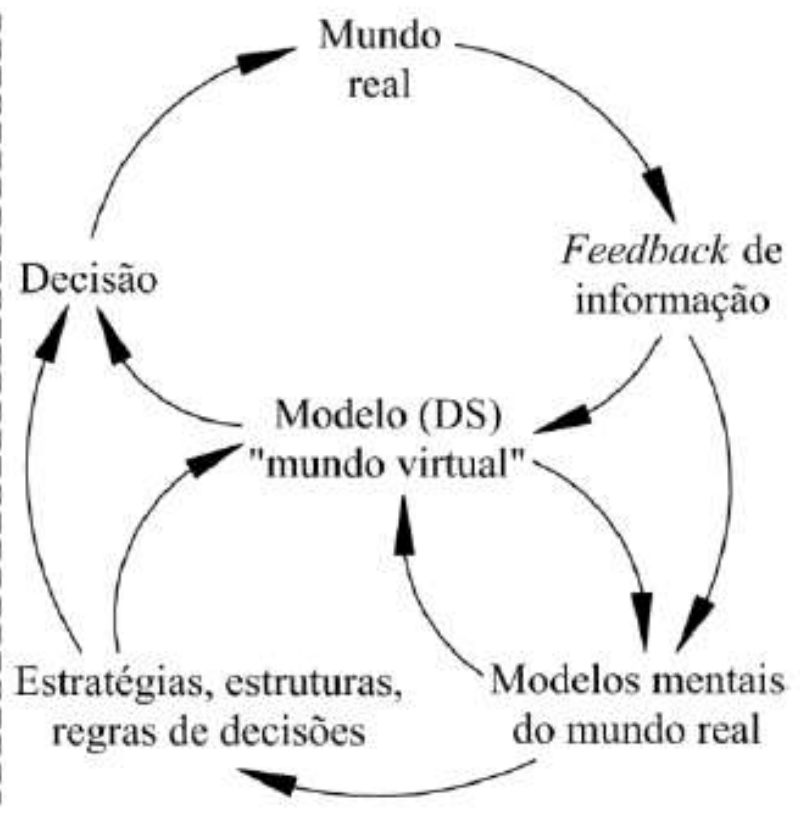

Fonte: Sterman (2000), tradução do autor.

Juntamente, esta análise apresenta contribuições para a academia ao descrever o emprego da dinâmica de sistemas em um tema em particular. Essa aplicação explora a flexibilidade do instrumento, esclarecendo sobre as possibilidades de aplicação e possibilitando a comparação dos resultados obtidos aos resultados de análises acerca do mesmo fenômeno que eventualmente sejam realizadas utilizando-se de outros instrumentos de intervenção.

\subsection{ORIGEM E DEFINIÇÃO}

A evolução da Dinâmica de Sistemas (System Dynamics) deu-se fundamentalmente a partir de trabalhos em sistemas de controle de servomecanismos e de sistemas eletrônicos de amplificação (FORRESTER, 1992). As características desses trabalhos conduziram à estruturação da metodologia com ferramentas específicas que abordam a relação entre os elementos do sistema conferindo suas características complexas de não linearidade. Os conceitos utilizados pela Dinâmica de Sistemas para o controle dos sistemas de engenharia, observando-os como sistemas abertos, adotam uma linguagem de integração alinhada aos fundamentos da teoria dos sistemas. Esses fundamentos, a partir da década de 1950, expandiram suas aplicações a todos os processos de mudança biológica, natural, ambiental e social (FORRESTER, 1992). 
A metodologia da Dinâmica de Sistemas tem o ciclo de realimentação ${ }^{12}$ como o elemento estrutural básico dos sistemas (FORRESTER, 2005). Por estes ciclos são representadas as estruturas sistêmicas relacionando os elementos e definindo o comportamento. Assim, a metodologia Dinâmica de Sistemas trabalha com o comportamento dos sistemas em dependência do tempo e emprega modelos qualitativos e quantitativos objetivando a descrição dos sistemas e o entendimento sobre qual ciclo de realimentação de informação governa seu comportamento (COYLE, 1996).

O paradigma da DS está no ciclo informação/ação/consequência. Considera que o "estado do sistema" produz uma "informação" por meio de fatores percebidos que caracterizam o estado. Essa informação leva o "conhecimento" do estado atual do sistema que, frente ao estado desejado, acarreta "ações" na tentativa de minimização da discrepância entre esses dois estados. Da "escolha" tomada na readaptação do sistema um novo estado é gerado. A Figura 3 representa esse paradigma, sendo essa sequência que atribui o comportamento dinâmico dos sistemas.

Figura 3 - Paradigma da Dinâmica dos Sistemas

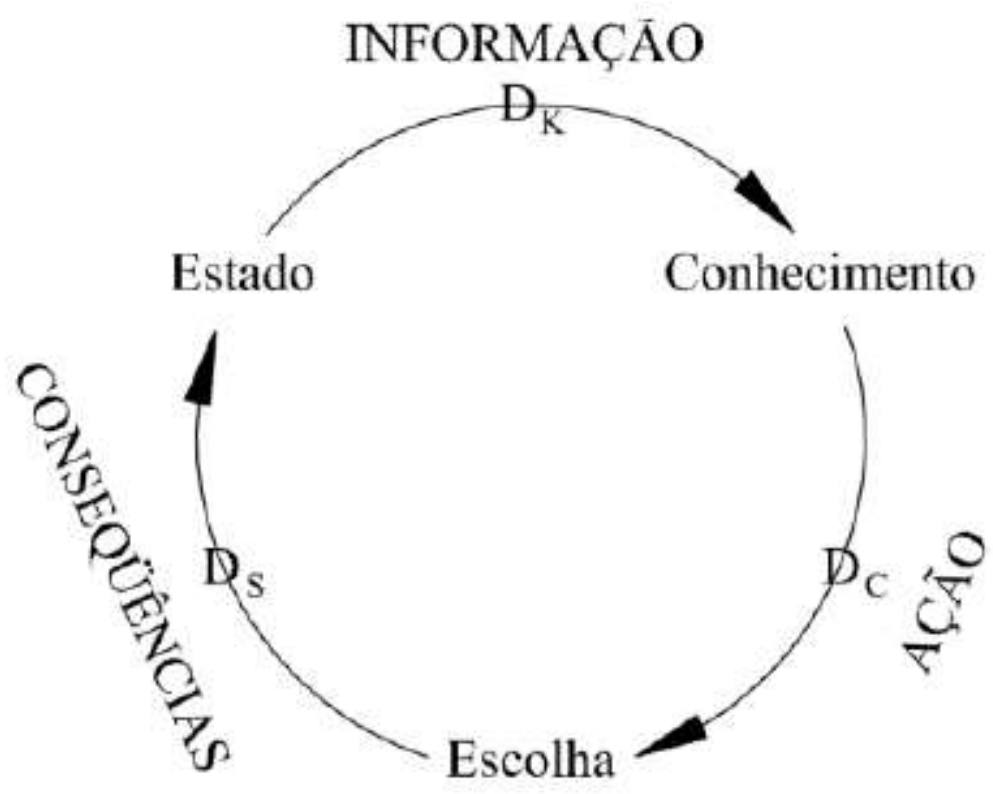

Fonte: Coyle (1996).

No entanto, como também está denotado na Figura 3, defasagens de tempo podem estar atuando na sequência dos componentes de informação/ação/consequência (DK, DC e DS, respectivamente). Dessa maneira, o padrão de comportamento ${ }^{13}$ da mudança do estado ao longo do tempo de um sistema particular depende do quão bem a informação e as ações estão ajustadas, considerando as defasagens existentes, e ao modo como as consequências surgem nesse sistema (COYLE, 1996). 


\subsection{ESTRUTURAÇÃO DA METODOLOGIA}

A estruturação da Dinâmica de Sistemas segundo Coyle (1996) é apresentada na Figura 4. O primeiro estágio consiste no reconhecimento do problema, reconhecimento de para quem (qual ou quais stakeholders) este problema é significativo e por que. Posteriormente, no estágio 2, o sistema é descrito qualitativamente por meio dos diagramas de influência (ou diagramas de enlace causais, ou ainda, diagramas de causalidades). Estes diagramas são modelos conceituais ou interpretativos que auxiliam o entendimento, não somente do problema, mas também das diferentes visões sobre este, advindas das diferentes funções dos atores no sistema. O estágio 3 analisa qualitativamente a descrição conceitual, estabelecendo novas ideias sobre o fenômeno, estimulando o questionamento e, consequentemente, refinando-o. Neste estágio, conforme (COYLE, 1996), se o problema for compreendido de forma a estabelecer condições de sua resolução, atingindo o objetivo da Dinâmica de Sistemas, não é necessário proceder no processo. Isto é representado na Figura 4 pelo uso da linha tracejada entre os estágios 3 e 4. Caso contrário, evolui-se ao estágio 4 que corresponde à conversão do modelo qualitativo em modelo quantitativo em uma linguagem de fluxos e estoques para prover a (ligação entre os estágios 2 e 4 na Figura 4). Corresponde em expressar a relação entre os fatores considerados em termos matemáticos. A linguagem de fluxos e estoques também será abordada novamente na sequência. O estágio 5 emerge do início da análise qualitativa. Inicialmente são analisadas as ideias e teorias postas sobre o sistema (ligação entre o estágio 3 e o estágio 5 representada na Figura 4). Os estágios 5A e 5B representam as alterações e implementações idealizadas para resolver os problemas. Corresponde a testes realizados no ambiente de simulação anteriormente a implementação no fenômeno real. 
Figura 4- Estruturação da análise pela Dinâmica de Sistemas

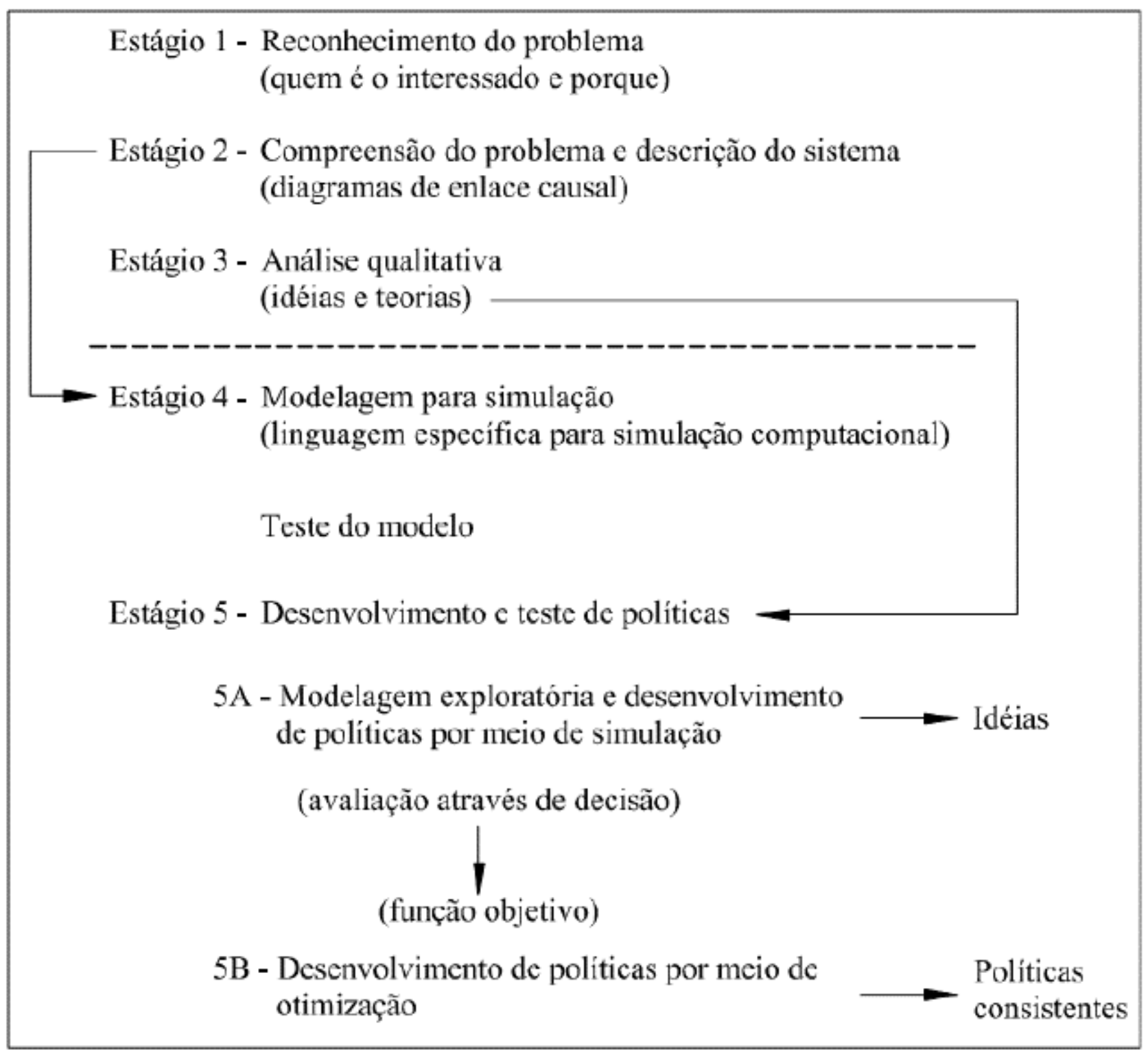

Fonte: Coyle (1996).

Na sequência são detalhados os estágios desta estruturação da Dinâmica de Sistemas utilizados neste trabalho (estágios 1, 2, 3 e 4) por serem necessários e suficientes para a realização desta análise. Dessa forma, são apresentados os termos da abordagem e apresentadas às representações (adotadas neste trabalho) referentes às ferramentas empregadas pela Dinâmica de Sistemas na descrição de sistemas. Essas representações guardam algumas diferenças entre o exposto por diferentes autores que trabalham a Dinâmica de Sistemas, mas que não são significativas, de forma que a linguagem da Dinâmica de Sistemas pode ser compreendida com pequenas variações. 


\subsubsection{ESTÁGIO 1 - RECONHECIMENTO DO PROBLEMA}

A descrição do problema deve ser completa, de forma a especificar o sistema a ser abordado, porém não demasiadamente extensa (SENGE et al., 1999). Deve possuir caráter dinâmico de forma a expressar uma preocupação relacionada ao comportamento do sistema (por exemplo: oscilação da demanda, imprevisão da demanda, queda no faturamento, crescimento sem controle das reclamações). Juntamente deve expressar a relação temporal do problema. Assim, o problema é abordado e interpretado de forma alinhada ao paradigma da Dinâmica de Sistemas viabilizando e facilitando a construção do conhecimento sobre tal e, permitindo o reprojeto do sistema e sua adequação ao comportamento esperado.

A indagação do propósito do problema, a atribuição da relevância do problema a alguém ou algum grupo define também o ponto de vista pelo qual o problema será analisado. Frente aos diferentes stakeholders envolvidos no sistema o problema abordado pode assumir diferentes aspectos. Diretamente associados a estes aspectos estão os limites do sistema e todos os fatores considerados necessários e suficientes na explicitação da estrutura do sistema e relacionamentos entre esses fatores formando a estrutura.

No entanto, Coyle (1996) salienta que muito raramente estas questões são respondidas completa ou adequadamente neste primeiro estágio. Neste sentido, a metodologia da Dinâmica de Sistemas favorece o aprendizado ao longo do processo ajudando no entendimento do problema de forma que, com reanálises é possível "lapidar" as respostas iniciais. Isto porque o trabalho na Dinâmica de Sistemas não segue as etapas do processo linearmente, mas sim interativamente, como será mostrado na sequência.

\subsubsection{ESTÁGIO 2 - COMPREENSÃO DO PROBLEMA E DESCRIÇÃO DO SISTEMA (MODELAGEM QUALITATIVA)}

A compreensão é gerada pela descrição da lógica do problema abordado, exploração de ideias e discussões construtivas. Na pesquisa e desenvolvimento isto pode ser viabilizado com a modelagem qualitativa (ou interpretativa, ou conceitual). Este estágio, então, objetiva a descrição da estrutura do sistema, não só como produto do estágio, mas também como auxílio para uma compreensão do sistema abordado.

Na descrição do sistema o "diagrama de causalidade" é a ferramenta utilizada pela Dinâmica de Sistemas. Consiste em uma lista de fatores de um problema, sendo que setas e sinais mostram o 
relacionamento entre estes fatores (COYLE, 1996). Este diagrama descreve o sistema abordado, associando os ciclos de realimentação e formalizando a sua estrutura do sistema. A representação da estrutura do sistema pelo diagrama de influencia constitui o modelo conceitual da abordagem Dinâmica de Sistemas explicitando como o processo sistemático de informação/ação/consequência se sucede no sistema abordado. Os termos e representações necessárias ao entendimento dos diagramas de influência que serão construídos neste trabalho são:

Fatores ou variáveis: Os fatores ou variáveis são a representação verbal e escrita da interpretação humana dos componentes que compõem e formam as estruturas dos sistemas e, dessa forma, promovem o comportamento dinâmico dos componentes de informação/ação/consequência. 0 termo fator ou variável possuem conotações referentes ao sistema analisado. Esses termos são contextualizados pela abordagem desenvolvida. Dessa maneira, se abordado um sistema puramente técnico os fatores envolvidos poderiam corresponder a: temperatura inicial, diferença de temperaturas, taxa de resfriamento, etc. Já se a abordagem ocorre em um contexto sócio técnico, então os fatores envolvidos neste, dependendo do foco da abordagem, poderiam corresponder a: motivação, capacidade de desenvolver uma atividade, capacidade de comunicação, entre outros. Também, chamam-se fatores exógenos aos relativos ao ambiente, não podendo ser manipulados pela gestão do sistema; e fatores endógenos os integrantes internos dos sistemas.

Relações de causalidade: As "relações causais" (ou relações de causa e efeito) constituem a representação da relação entre duas variáveis, a causa e seu efeito. São representadas graficamente por uma seta e um sinal. Há dois tipos de relações de causalidade: as relações positivas e as negativas. A relação causal positiva é identificada por uma seta e um sinal positivo. Esta indica que "se ocorrer um aumento na causa o efeito também aumentará acima do que aumentaria caso tal aumento não ocorresse e vice-versa" (STERMAN, 2000). A relação causal negativa é identificada pro uma seta e um sinal negativo. Por sua vez, indica que "se ocorrer um aumento na causa o efeito diminuirá abaixo do que diminuiria caso tal aumento não ocorresse e vice-versa" (STERMAN, 2000). O Quadro 2 ilustra as possíveis relações causais entre dois fatores. As relações causais são os elementos básicos dos ciclos de realimentação. 
Quadro 2 - Relações de causalidade

\begin{tabular}{|c|c|}
\hline Relação causal & Interpretação \\
\hline Relação causal positiva & $\begin{array}{l}\text { Representa proporcionalidade direta. Logo, se o "número de tarefas" } \\
\text { aumentar, o "trabalho a realizar" também aumentará. Caso o "número de } \\
\text { tarefas" diminuir, o mesmo ocorrerá com o "trabalho a realizar". }\end{array}$ \\
\hline Relação causal negativa & $\begin{array}{l}\text { Representa proporcionalidade inversa. Assim, se os "recursos } \\
\text { disponíveis" para a execução de uma tarefa aumentar, o "tempo para }\end{array}$ \\
\hline $\begin{array}{l}\text { Tempo para } \\
\text { conclusão }\end{array}$ & $\begin{array}{l}\text { conclusão" da mesma diminuirá. Porém, se os "recursos disponíveis" } \\
\text { tornarem-se escassos, o "tempo para conclusão" da tarefa irá aumentar. }\end{array}$ \\
\hline
\end{tabular}

Fonte: o autor.

Ciclo de realimentação: São os elementos básicos dos diagramas de causalidade. As estruturas dos sistemas apresentam, no entanto, apenas dois tipos de ciclos de realimentação atuando para gerar os diversos padrões de comportamento observados. Esses são: o ciclo de realimentação positivo e o ciclo de realimentação negativo. O ciclo de realimentação positivo é caracterizado pelo fato que quando um fator qualquer deste ciclo tem uma variação (de aumento, por exemplo) as relações causais envolvidas no ciclo fazem com que esta mesma variável seja realimentada com uma variação no mesmo sentido (neste exemplo, uma variação de aumento novamente). Ou seja, este ciclo representa a estrutura sistêmica responsável pelo crescimento exponencial, no qual o "estado atual" de um sistema é amplificado com uma "taxa de mudança" determinada por "parâmetros de mudança". A constituição básica desse tipo do ciclo é mostrada na Figura 5. Já o ciclo de realimentação negativo representa ações que levam à estabilização de um sistema, conhecido como o padrão de comportamento "busca pela meta". Neste ciclo, quando um fator qualquer tem uma variação, as relações causais envolvidas no ciclo fazem com que essa mesma variável seja realimentada com uma variação no mesmo sentido oposto. Para tal, como mostra a constituição básica do ciclo de realimentação negativo mostrado na Figura 6, o sistema compara o "estado atual", sujeito a "implicações externas", ao "estado desejado" e aplica "ações" para diminuir a "diferença entre estes estados". 
Figura 5- Representação gráfica do "ciclo de realimentação positivo"

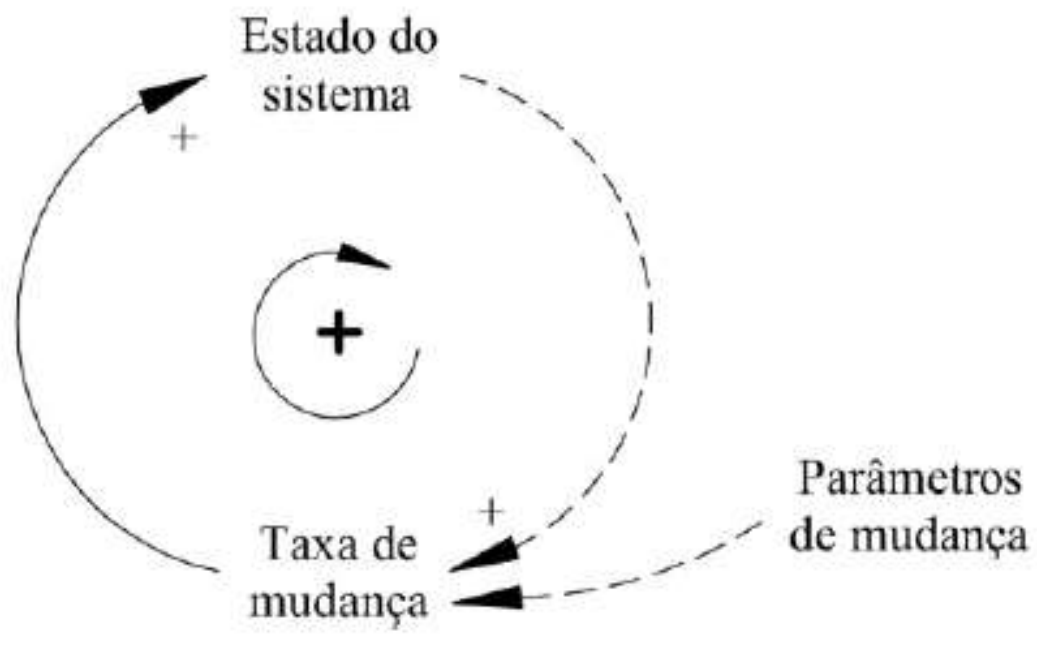

Fonte: Adaptado de Coyle (1996).

Figura 6 - Ciclo de realimentação negativo

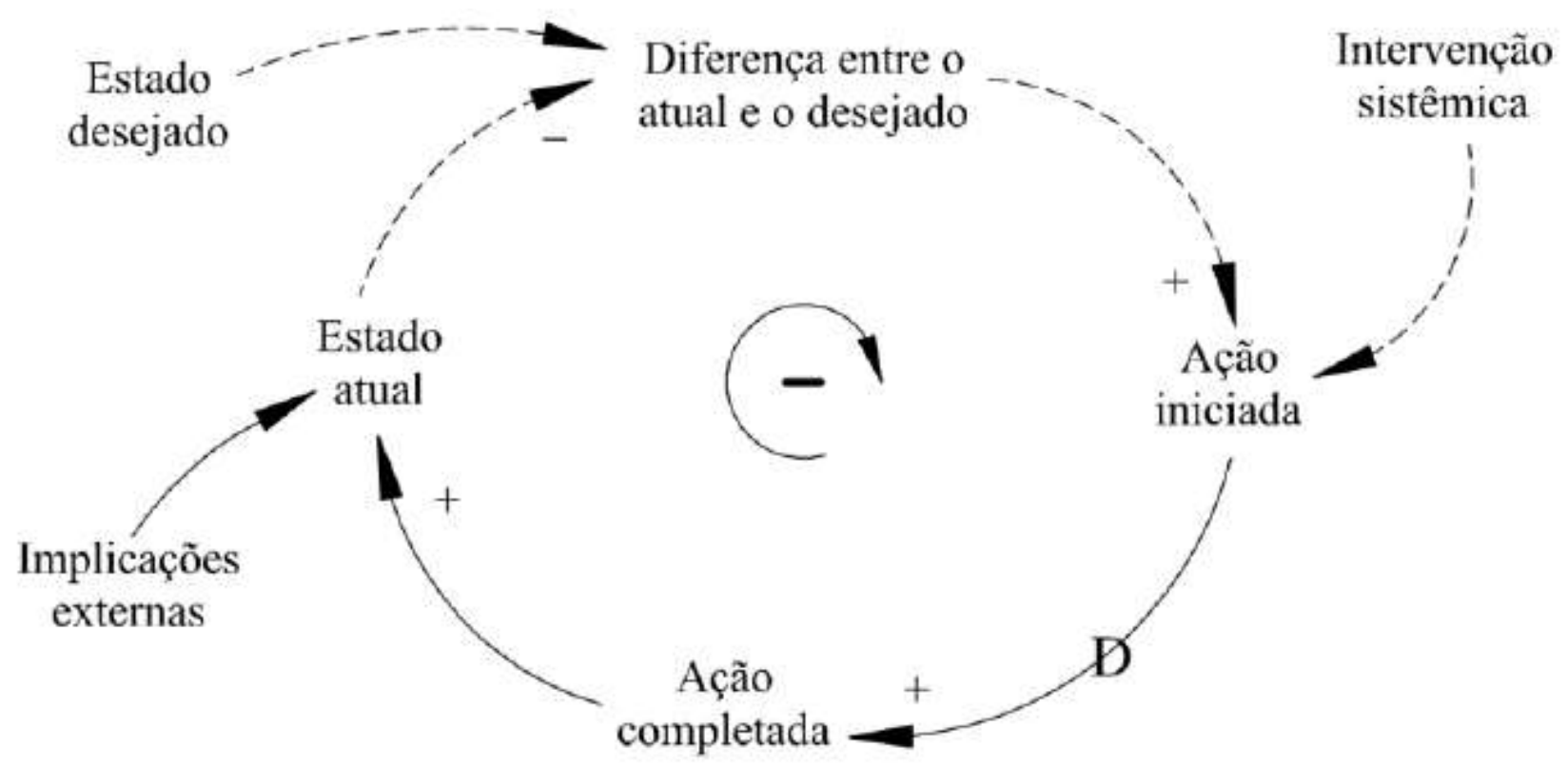

Fonte: Adaptado de Coyle (1996).

$\mathrm{Na}$ representação da Figura 5 e da Figura 6 o elemento de "consequência" do paradigma informação/ação/consequência, ou seja, o que flui no sistema é representado com a ligação entre os fatores deste elemento feita por linha contínua. Os fatores relativos aos elementos de "informação" e "ação" que geram e são geradas pelas mudanças de estado do sistema são interligados por linha tracejada. Em um diagrama de influência o fluxo do sistema é o aspecto de mudança e nele são ligados os vários ciclos de realimentação formados pelas variáveis associadas (os principais fatores considerados pertinentes ao sistema dentro dos limites estabelecidos). O ciclo de realimentação 
positivo em um diagrama de influência é identificado com um semicírculo contendo o sinal "+" que é explicitado interno ao ciclo. O ciclo de realimentação negativo, por sua vez, é identificado com um semicírculo contendo o sinal "-". Ainda as variáveis exógenas (cujas influências são externas aos limites do sistema) são representadas em uma caixa para diferenciá-las das demais.

\subsubsection{ESTÁGIO 3 - ANÁLISE QUALITATIVA}

A análise qualitativa do modelo primeiramente auxilia na construção do conhecimento sobre o sistema analisado. Juntamente estabelece confiança de que o modelo é útil para o propósito da análise. Engloba a análise dos ciclos de realimentação e análise das teorias sobre o sistema.

Ao analisar os ciclos de realimentação busca-se identificar, caso tratem-se de ciclos negativos, se estes deixam claros os estados desejados para o sistema, se representam realmente o objetivo desejado para o ciclo (se os fatores que refletem os esforços do ciclo estão em, por exemplo, manter um determinado nível de estoque de suprimentos caso o sistema se proponha a tal) (COYLE, 1996). Caso contrário, seria muito improvável um ciclo de realimentação negativo tem sucesso em eliminar as discrepâncias e poderia mostrar evidências de que estaria fora de controle (como se o nível de estoque de suprimento, citado como exemplo anterior, não pudesse nunca ser obtido). Da mesma maneira, caso haja ciclos de realimentação positivos, esses são analisados de modo a identificar pelo mesmo raciocínio lógico se estes produzem o comportamento esperado (o crescimento ou redução exponencial). Ainda, o conjunto de ciclos de realimentação quando possui ciclos positivos deve sempre apresentar junto a estes os ciclos negativos que limitam o crescimento exponencial (o que é observado no comportamento real dos sistemas). Por fim, em um nível mais avançado um conjunto de ciclos de realimentação identificados para o sistema em análise pode ser comparado a conjunto de ciclos de outros sistemas que guardam particularidades, de forma que novas idéias possam ser geradas e o modelo complementado.

\subsubsection{ESTÁGIO 4 - MODELAGEM PARA SIMULAÇÃO}

Os modelos quantitativos (ou matemáticos) são utilizados para a análise minuciosa na qual a capacidade de compreensão humana se torna insuficiente. Estes viabilizam a simulação computacional que utiliza o cálculo numérico implementado em computador para imitar o comportamento de um sistema. Assim, uma vez que o modelo estiver construído e as condições iniciais especificadas, podem ser simuladas comportamentos com diferentes valores de variáveis ao longo do tempo (MARTIN, 1997). O diagrama de fluxos e estoque é a ferramenta da Dinâmica de 
Sistemas que permite a simulação computacional. Utiliza uma linguagem específica e comum para os softwares que operacionalizam modelos na abordagem da Dinâmica de Sistemas.

A representação básica de um diagrama de fluxos e estoque é mostrada na Figura 7. Nesta, as "variáveis", que também estão no diagrama de influência já abordado, representam da mesma forma os fatores de influência, direta ou indireta, nos estoques e nos fluxos. As variáveis representam os componentes de "informação" e "ação" do paradigma da Dinâmica de Sistemas atuantes no sistema. Em uma analogia com um circuito formado por tubos interligados a um tanque de forma que água possa fluir pelos tubos enchendo o tanque, como também escoando e fazendo o tanque esvaziar (analogia muito utilizada pelos autores), o "estoque" representa a quantidade de água acumulada no tanque. Já os "fluxos" consistem na taxa de alteração do estoque. Logo, em qualquer ponto no tempo a quantidade de água no tanque reflete o acúmulo do fluxo de entrada, menos o que está fluindo para fora do tanque. Os estoques e os fluxos representam as "consequências" no paradigma informação/ação/consequência. Apresentam-se quando, por exemplo, dinheiro é transferido, bens são manufaturados, pessoas são recrutadas, sendo que, mesmo em casos psicológicos, sentimentos crescem e decrescem em um sistema particular. Assim, a Dinâmica de Sistemas pode ser empregada tanto em sistemas em que o fluxo identificado é concreto e facilmente mensurável, até sistemas em que o fluxo é abstrato (COYLE, 1996). Os conectores consistem em segmentos de curvas terminados em setas que transmitem informações entre variáveis e variáveis, variáveis e estoques, variáveis e fluxos, e estoques e fluxos. As entradas e saídas são representadas por "nuvens" e determinam os limites do modelo. Considera-se que a origem, assim como o destino do fluxo, não é relevante para o entendimento do sistema.

Figura 7 - Linguagem de Fluxo e Estoques para a modelagem estrutural

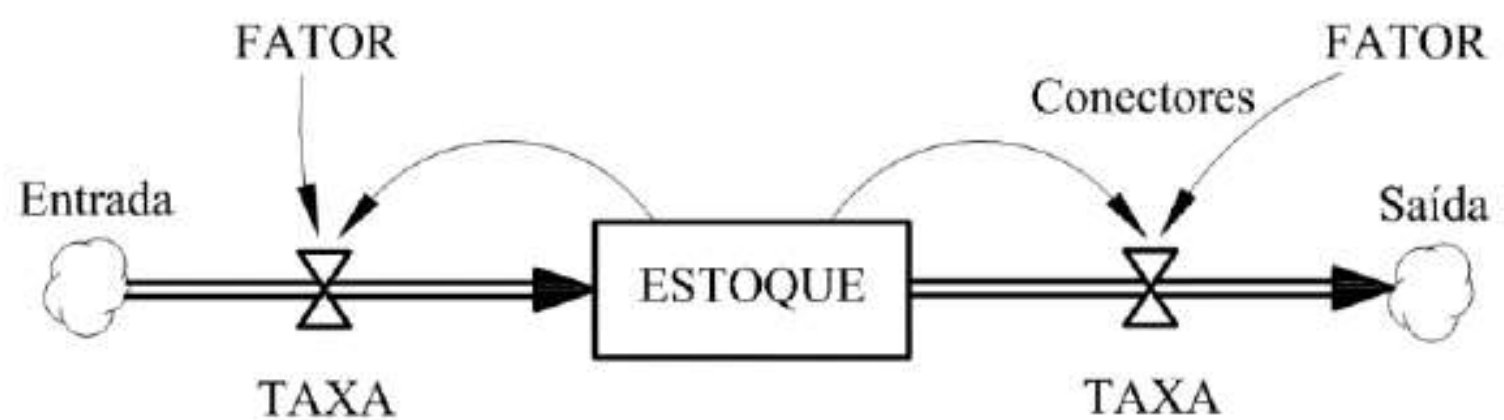

Fonte: Sterman (2000). 
Assim, os estoques acarretam em níveis, assim como os fluxos estão relacionados às taxas. Estes, níveis e taxas, são fundamentais para a subestrutura de ciclo e são os componentes primários da estrutura do sistema (FORRESTER, 1993). Os níveis e taxas não são distinguíveis pelas suas unidades de mensuração, visto que, por exemplo, a "velocidade" em um determinado sistema pode ser exposta como uma taxa que aumenta a "distância" (sendo então à distância o nível do sistema) ou a velocidade, em outro sistema, pode ser exposta como o acúmulo (nesse caso um nível) da aceleração (neste caso a taxa) (FORRESTER, 1993). Portanto, um componente particular do sistema analisado não tem sua função (níveis ou taxas) no modelo definido pela sua unidade de mensuração. Isto atribui a Dinâmica de Sistemas flexibilidade na abordagem dos problemas frente às possíveis interpretações e pontos de vista para análise do problema.

\subsubsection{TESTES E VALIDAÇÃO DO MODELO}

Os testes realizados aos modelos na DS têm a validação do modelo como um processo cujo objetivo consiste em estabelecer confiança tanto na solidez quanto na utilidade deste modelo (FORRESTER; SENGE, 1980). A validação do modelo não é realizada com um único teste visto que a confiança no modelo aumenta gradualmente à medida que o modelo é submetido a diferentes testes e, também, aprimorado por estes testes (FORRESTER; SENGE, 1980). Neste sentido, são aplicados testes qualitativos e quantitativos, ambos importantes para esta validação. Dessa forma, a validação do modelo é um processo que depende do contexto sociocultural em que o modelo foi construído (STERMAN, 1984).

\subsubsection{PROGRAMA DE SIMULAÇÃO COMPUTACIONAL VENSIM ${ }^{\circledR}$}

O VenSim ${ }^{\circledR}$ (marca registrada de Ventana Systems Inc.) é um conjunto de ferramentas para modelagem e simulação computacional ${ }^{14}$. Permite criar, documentar, simular, analisar e otimizar modelos de simulação na linguagem da Dinâmica de Sistemas fornecendo uma forma simples e flexível de construir modelos de simulação por diagramas de influência ou diagramas de fluxo e estoque.

No pacote de softwares disponibilizado pela Ventana Systems estão: Vensim PLE, Vensim PLE Plus, Vensim Professional, Vensim DSS, Model Reader e Molecules. O Vensim PLE (Personal Learning Edition) é uma versão do software de uso exclusivo educacional disponibilizado para download gratuito pelo site http://vensim.com/free-download/. O Vensim PLE Plus é constituído de todas as funcionalidades do Vensim PLE incluindo ainda: conectividade de dados, múltiplas visualizações, simulação de 
sensibilidade "Monte Carlo", simulações de jogos, e interface diferenciada (VENTANA SYSTEM, 2012). Já o Vensim Professional é direcionado para modelos grandes e complexos contendo funcionalidades específicas de análise estrutural e de comportamento do modelo, enquanto a versão DSS ainda permite funções externas e macros para a compilação (VENTANA SYSTEM, 2012). O Model Reader consiste também em uma ferramenta de distribuição gratuita que possibilita a visualização de modelos. O software Molecules, por fim, é utilizado para a construção de modelos a partir de "blocos" ou "moléculas" de estruturas da Dinâmica de Sistemas.

Para a realização desta análise foi utilizado o software Vensim PLE (versão 6.1). Mesmo limitadas nesta versão as funcionalidades do software se mostraram suficientes para a realização desta análise.

\section{FUNDAMENTAÇÃO TEÓRICA}

A fundamentação teórica aborda os conceitos necessários ao entendimento do trabalho. Para tanto a fundamentação teórica desta abordagem é dividida em três partes: a fundamentação da gestão conforme a perspectiva sistêmica, a fundamentação teórica geral e fundamentação teórica específica (estado atual do conhecimento). A fundamentação teórica geral trata do tema abordado (o Sistema Produto-Serviço) de forma abrangente. Esse é apresentado salientando a evolução da definição do conceito, são descritos os elementos que o constituem e a forma de classificação. Já a fundamentação específica trata do ciclo de vida do produto no contexto do PSS, da organização do sistema e da sua dinâmica e fatores de influência.

\subsection{SISTEMA PRODUTO-SERVIÇO (VISÃO GERAL)}

O PSS é apontado como uma estratégia obtida sob a evolução em dois extremos: a "servitização" e a "produtização" (BAINES et al., 2007). A servitização de produtos corresponde ao movimento de agregação de serviços aos mercados que exploravam essencialmente bens tangíveis, enquanto que a produtização corresponde à agregação de bens tangíveis aos mercados de serviço puro.

Ao que se referente às definições atribuídas ao PSS pelos autores, o Quadro 3 apresenta uma relação situada no período do ano de 1999 ao ano de 2010. Desta relação pode- se apontar o PSS como uma estratégia de negócio que se apresenta sob a forma de um sistema e, como tal, conta com seus elementos e suas interações para a viabilização desta estratégia. Esses elementos consistem no bem tangível e no serviço, cuja associação determina o valor entregue pelo PSS, contando também com a infraestrutura necessária a sua realização e uma rede de atores, sendo todos os influenciados ou influenciadores, que conforme suas devidas atribuições são responsáveis pela viabilização do PSS. Com 
isso o PSS pode ser projetado de forma que a agregação de diferentes componentes de serviços aos bens tangíveis satisfaça as necessidades específicas dos consumidores, sendo assim, uma oportunidade de diferenciação aos fabricantes em relação aos que adotam a estratégia convencional. A combinação dos componentes de serviços aos bens pode conduzir a venda da funcionalidade, e não do artefato físico, conferindo os benefícios ambientais apontados ao PSS. Esses aspectos ressaltados orientam as considerações realizadas sobre o PSS nesta análise.

Quadro 3 - Definições do conceito de Sistema Produto-Serviço

\begin{tabular}{|c|c|}
\hline Autor(es) & Definição de PSS \\
\hline $\begin{array}{c}\text { Goedkoop et al. } \\
\text { (1999) }\end{array}$ & $\begin{array}{l}\text { "Um PSS é um sistema que abrange produtos, serviços e redes de } \\
\text { atores, que são apoiados por uma infraestrutura que busca a } \\
\text { competitividade contínua, satisfazendo as necessidades dos } \\
\text { consumidores com menores impactos ambientais que as estratégias } \\
\text { de negócios tradicionais". }\end{array}$ \\
\hline $\begin{array}{l}\text { Centre For } \\
\text { Sustainable Design } \\
\text { (2002) }\end{array}$ & $\begin{array}{l}\text { "Um PSS envolve produtos e serviços que são apoiados por uma } \\
\text { infraestrutura e redes de atores necessárias para atender as } \\
\text { necessidades do mercado, com menor impacto ambiental que } \\
\text { produtos e serviços separados". }\end{array}$ \\
\hline Mont (2001) & $\begin{array}{l}\text { "Um sistema de produtos e serviços, apoiados pela rede de atores e } \\
\text { infraestrutura que são projetada para que o negócio seja competitivo, } \\
\text { satisfaça as necessidades dos consumidores e tenha menores } \\
\text { impactos ambientais que tradicionais modelos de negócio". }\end{array}$ \\
\hline $\begin{array}{l}\text { Manzini e Vezolli } \\
\qquad(2003)\end{array}$ & $\begin{array}{l}\text { "Uma estratégia de inovação, deslocando o foco do negócio somente } \\
\text { da concepção (e venda) de produtos físicos, para a concepção (e } \\
\text { venda) de um sistema de produtos e serviços que juntos são capazes } \\
\text { de cumprir as demandas específicas dos consumidores". }\end{array}$ \\
\hline $\begin{array}{c}\text { Brandstotter } e t \\
\text { al.(2003) }\end{array}$ & $\begin{array}{l}\text { "Um PSS consiste em produtos tangíveis e serviços intangíveis, } \\
\text { projetados e combinados de modo que sejam capazes de cumprir } \\
\text { específicas necessidades dos consumidores. Além disso, o PSS tenta } \\
\text { alcançar os objetivos do desenvolvimento sustentável". }\end{array}$ \\
\hline Wong (2004) & $\begin{array}{l}\text { "Um PSS pode ser definido como uma solução oferecida para a } \\
\text { venda que envolve tanto um produto como um elemento de serviço, } \\
\text { para entregar a requerida funcionalidade". }\end{array}$ \\
\hline
\end{tabular}




\begin{tabular}{|c|l|}
\hline $\begin{array}{c}\text { Tukker e Tischer } \\
(2006)\end{array}$ & $\begin{array}{l}\text { "Um PSS é o conjunto de produtos e serviços projetados para atender } \\
\text { às necessidades do consumidor". }\end{array}$ \\
\hline $\begin{array}{c}\text { Wimmer } \text { et al. } \\
(2007)\end{array}$ & $\begin{array}{l}\text { "Um PSS fornece aos consumidores valores funcionais e não } \\
\text { funcionais que aumentam a satisfação e reduzem o consumo de } \\
\text { materiais e energia". }\end{array}$ \\
\hline Kimita, & "Um PSS é uma oportunidade de diferenciação para os fabricantes, \\
\hline $\begin{array}{c}\text { Shimomura e Arai } \\
(2009)\end{array}$ & $\begin{array}{l}\text { os quais satisfazem seus clientes de forma individualizada e } \\
\text { sustentável". }\end{array}$ \\
\hline Kuo et al. (2010) & $\begin{array}{l}\text { "Um PSS melhora a eficiência por meio do serviço e da redução do } \\
\text { consumo de recursos e de resíduos com a remanufatura e o reuso de }\end{array}$ \\
\hline
\end{tabular}

Fonte: Baines et al. (2007) (1999 a 2005) ampliada por Beuren, Ferreira e Miguel (2011) (2006 a 2010).

Na estratégia convencional de concepção, produção e venda de bens tangíveis puros o valor entregue concentra-se essencialmente na venda. Contudo, a agregação de componentes de serviços a esses bens caracteriza a estratégia do PSS pela extensão da entrega de valor ao longo do ciclo de vida (PHUMBUA; TJAHJONO, 2011).

As práticas e estudos relatados na literatura acerca dos Sistemas Produto-Serviço apontam duas principais aplicações deste, sendo estas referentes as relações Business to Customer, ou então, Business to Business. Nas aplicações em Business to Customer ou B2C as relações comerciais são realizadas diretamente entre os produtores e prestadores e o consumidor final, característica destas relações. Neste caso alguns dos segmentos comerciais explorados compreendem a: indústria de mobilidade (WILLIAMS, 2007; MAUSSANG; ZWOLINSKI; BRISSAUD, 2008; KIMITA; SHIMOMURA; ARAI, 2009; WANG et al.,

2011), alimentícia (EVANS; PARTIDÁRIO; LAMBERT, 2007), micro energia (MÜLLER et al., 2009), entre outros. Já nas aplicações em que as relações comerciais ocorrem entre fabricantes e fabricantes em cadeias de suprimentos que caracteriza as relações comerciais Business to Business ou B2B o PSS também é referenciado como Sistema Produto-Serviço Industrial (Industrial Product-Service System ou IPS2) (RESE; KARGER; STROTMANN, 2009). Em relação ao B2B algumas aplicações do PSS exploram os segmentos de logística (LELAH; MATHIEUX; BRISSAUD, 2011), usinagem (ABRAMOVICl; BELLALOUNA;GÖBEL, 2010), construção de máquinas (AURICH; FUCHS; WAGENKNECHT, 2006), entre outros. 


\subsubsection{ELEMENTOS DO PSS}

A dinâmica do PSS é resultante da interação entre os elementos que o constituem. Sendo assim, o bem tangível, o serviço, a infraestrutura e a rede de atores (MONT, 2004; ALONSO, 2007) podem ser configurados de forma a atender os objetivos do PSS.

\subsubsection{BEM TANGÍVEL}

No tratamento do PSS por esta análise o bem tangível se refere ao objeto ou artefato físico, artigo ou material central (MONT, 2004; ALONSO, 2007; LELAH; MATHIEUX; BRISSAUD, 2011) ao qual é agregado o valor intangível dos serviços. Portanto, consiste na parte tangível do "pacote de valor" do sistema. Essa parte tangível também é referenciada de maneira simplificada por alguns autores com o uso do termo "produto". No entanto, como já salientado, o termo "produto" tem sentido amplo podendo ser empregado como referência a um bem tangível ou intangível (NICKELS; WOOD, 1999). Portanto, essa abordagem busca estabelecer uma diferenciação entre esses termos.

Em termos econômicos mesmo uma empresa especificamente manufatureira apresenta serviços internos de suporte ao sistema de manufatura. São serviços necessários às operações de manufatura que, nessa abordagem, estão englobados no sistema de produção e não afetam diretamente a percepção do consumidor.

\subsubsection{SERVIÇO}

O entendimento do termo "serviço" nesta abordagem está vinculado às definições relativas à gestão das organizações e se refere às operações específicas dos prestadores. Nesse sentido os serviços referem-se às atividades ou satisfação que são ofertadas mediante a compra de um serviço ou vinculadas com a venda de algum bem tangível (LAS CASAS, 1991). É oferecido de uma parte à outra sendo essencialmente intangível e não resultando em propriedade (KOTLER, 1998). Portanto, em contraste com os bens tangíveis, os serviços englobam ações, esforços ou desempenho (HOFFMAN; BATESON, 2002).

Os serviços possuem características específicas. Uma destas, como ressaltado anteriormente, consiste na sua (i) intangibilidade. Ao contrário dos bens manufaturados os serviços não podendo ser possuído pelos consumidores. Também, como destacam Aurich; Fuchs e Wagenknecht (2006), (ii) os serviços não podem ser estocados, sendo consumidos à medida que são entregues. Com a produção ocorrendo ao mesmo tempo em que ocorre o consumo eventuais erros na realização dos serviços podem ser 
imediatamente percebidos pelos consumidores. Ainda, (iii) os serviços podem ocorrem com interações entre o consumidor do serviço e os atores responsáveis pela prestação. Nesse sentido o consumidor participa do processo passiva ou ativamente estabelecendo, de toda forma, um maior grau de contato entre a empresa e o cliente comparado a produção de bens.

Então, na abordagem ao PSS nesta análise, e sendo o PSS também composto pelo bem tangível (artefato), os serviços correspondem então à parcela intangível do "pacote entregue". Essa parcela intangível varia em proporção à parcela tangível. Pode se constituir em atividades que acompanham o bem tangível até atividades utilizam-se desse bem para entregar uma função ou produzir um resultado.

\subsubsection{REDE DE ATORES}

A rede de atores no PSS é compreendida basicamente pela rede de serviços e pela rede de produção. A rede de serviços (ou rede de prestação como será referenciada nesta abordagem) compreende os ramos e localização dos serviços, bem como sua distribuição podendo ou não envolver parcerias. Esta rede é responsável pela entrega regulamentar dos serviços no ciclo de vida do produto. Compreende desde o fabricante visto que este, além da produção dos componentes físicos do PSS, realiza o planejamento das ofertas de serviços complementares. Os "parceiros de serviços" são, então, os responsáveis pela distribuição dos bens tangíveis e prestação dos serviços. Também se enquadram nesta rede os vendedores e agências dos quais o fabricante pode depender em determinados mercados, e, inclusive, podendo envolver concessionários e filiais. $E$, enfim, os clientes que desempenham um papel importante durante a prestação dos serviços podendo interferir diretamente nestes. Já a rede de produção, por sua vez, compreende o fabricante e os fornecedores de peças, componentes, módulos ou subsistemas. É responsável pela produção do bem tangível principal do PSS a um número limitado de locais de produção.

\subsubsection{INFRAESTRUTURA}

A infraestrutura consiste nos recursos (energia, materiais, espaço, processos, práticas institucionais, entre outros) necessários à implementação do PSS. Um PSS pode utilizar somente a infraestrutura já disponível pelas organizações, mas pode, porém, exigir uma alteração no próprio arranjo institucional (WILLIAMS, 2007). Pode também utilizar uma infraestrutura compartilhada ou, ainda, a infraestrutura pública (como redes de comunicação) (LELAH; MATHIEUX; BRISSAUD, 2011). 


\subsubsection{CLASSIFICAÇÃO DO PSS}

De forma geral os possíveis PSS podem ser classificados considerando uma faixa transitória entre dois cenários opostos, um baseado puramente em bens tangíveis enquanto o outro um cenário cuja economia se baseia puramente em serviços (TUKKER, 2004). Essa progressão do bem tangível puro para os serviços puros representa a redução de unidades de material, viabilizada pela agregação de unidades de serviço na composição da entrega final do PSS. A Figura 8 representa a classificação dos PSS entre esses cenários opostos.

Figura 8- Classificação do PSS

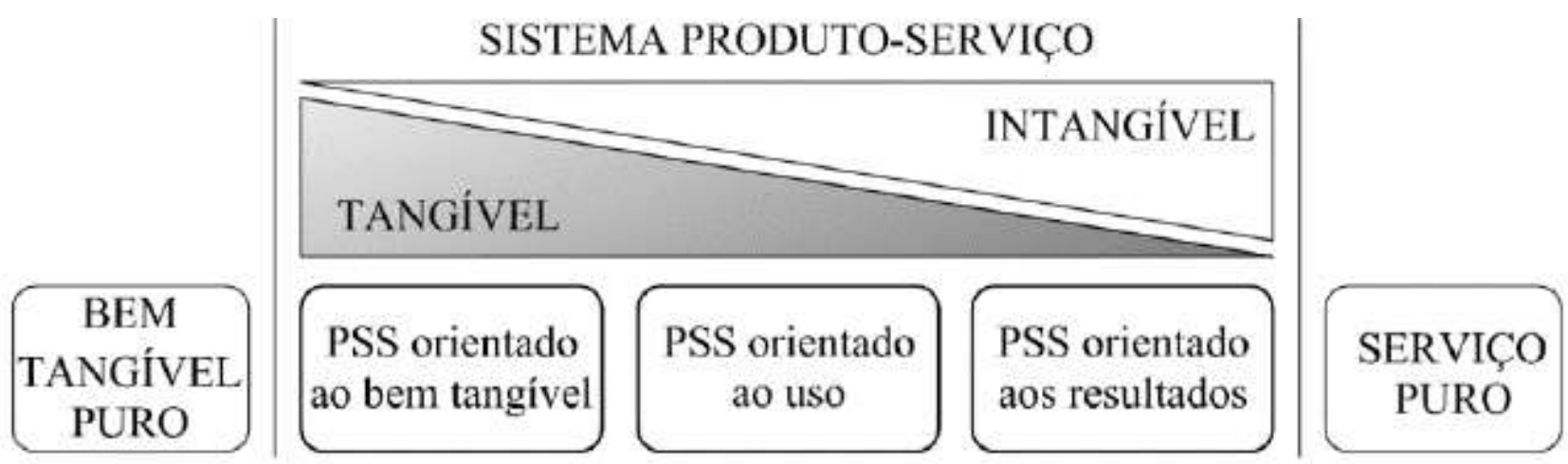

Fonte: Tukker (2004), tradução do autor.

Em termos práticos essa classificação do PSS categoriza as iniciativas quanto à proporção de representatividade do bem tangível e do serviço no pacote final. A seguir cada categoria do PSS é comentada.

- PSS orientado ao bem tangível: nesta categoria se enquadram as iniciativas PSS cujos serviços oferecidos complementam o bem tangível com a transferência de materiais ou informações entre provedor e consumidor, mas relacionados à utilização do bem. Em muitos casos estes serviços somente viabilizam ou facilitam a própria aquisição do produto. Mas, também nesta categoria encontram-se os PSS cujos serviços ao longo do ciclo de vida se direcionem ao funcionamento do bem tangível na fase de uso ou serviços da fase de fim de vida. Dessa forma no PSS orientado ao bem tangível objetiva-se a venda desse e de serviços que the agregam valor, sendo que a posse do bem tangível e consequentemente a responsabilidade pelo seu descarte continua sendo do consumidor.

- PSS orientado ao uso: nesta categoria os serviços estão direcionados a disponibilidade ou condições de uso do bem tangível como o aluguel, compartilhamento ou conjugação. O PSS orientado ao uso objetiva a venda da utilização do bem tangível junto de serviços que agregam valor a este. Nesta categoria a posse do bem físico pode ser diferenciada.

- PSS orientado ao resultado: as iniciativas PSS enquadradas nesta categoria oferecem um resultado acordado ou "parcelas" deste, sendo que somente o resultado funcional é negociado e o pagamento efetuado por unidades de uso, ou seja, o relativo ao uso do produto. O resultado 
ainda é obtido pela interação do bem tangível com os serviços, porém o produto necessário para a entrega da funcionalidade é definido conforme o planejamento do empreendimento. Nesta categoria encontram-se as iniciativas com um maior impacto no sistema. Também há um grande impacto na estrutura de posse do bem e nas responsabilidades demandadas por esta. Assim, o bem tangível continua pertencendo ao provedor do PSS que também detêm a responsabilidade de descarte do artefato em seu término de vida.

Para exemplificar como podem ser desenvolvidas iniciativas PSS enquadradas nas diferentes classificações citadas o Quadro 4 apresenta alguns exemplos. Todos esses exemplos correspondem à indústria automotiva, ou seja, o mesmo bem tangível (o automóvel) pode estar envolvido em diferentes configurações e abrangências de serviços.

Quadro 4 - Classificação de iniciativas PSS na indústria automotiva

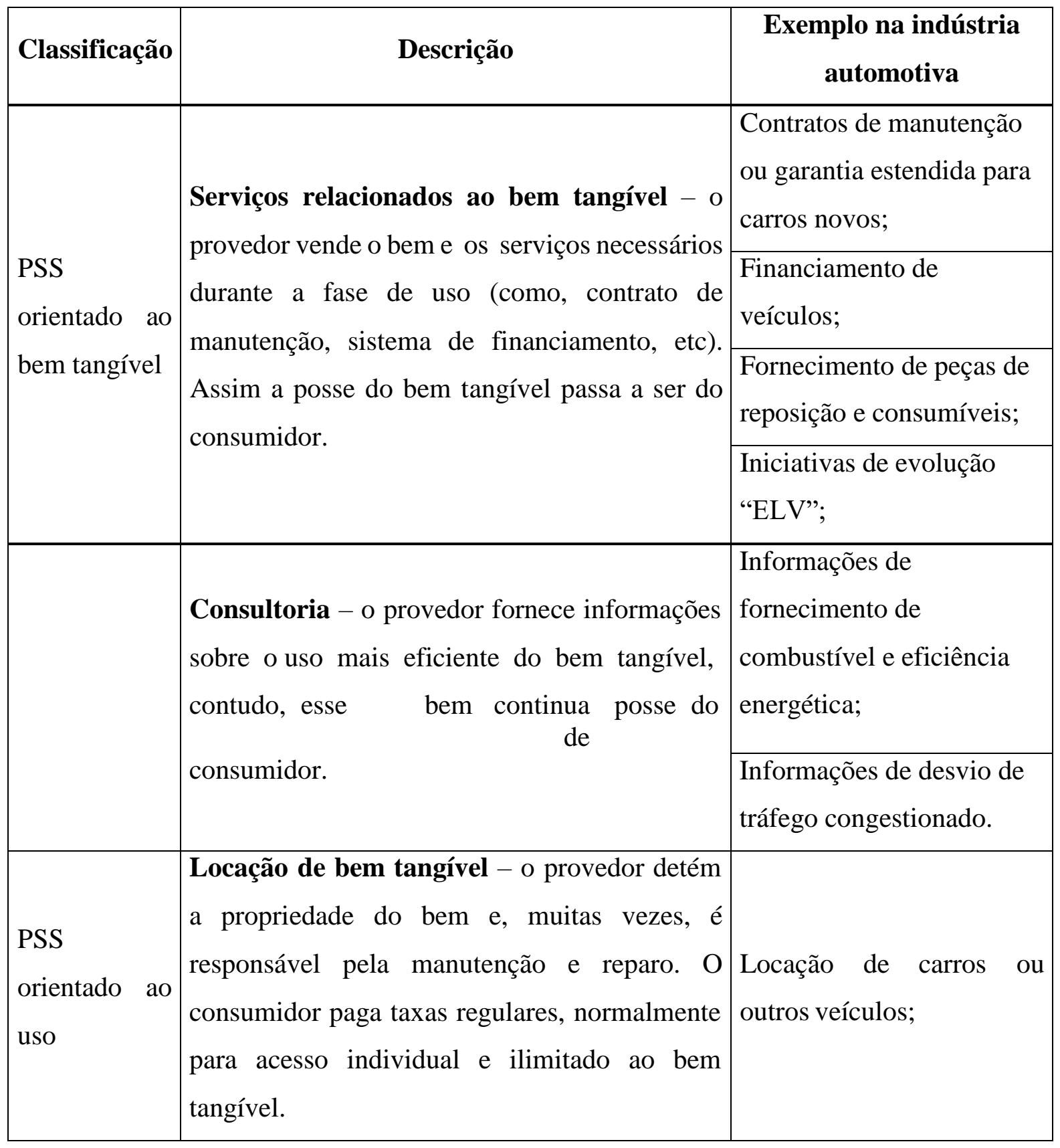




\begin{tabular}{|c|c|c|}
\hline \multirow{2}{*}{$\begin{array}{l}\text { PSS } \\
\text { orientado ao } \\
\text { uso }\end{array}$} & $\begin{array}{l}\text { Partilha do bem tangível - o provedor retém a } \\
\text { propriedade do bem e, muitas vezes, é } \\
\text { responsável pela manutenção e reparo. O } \\
\text { consumidor paga taxas regulares, mas não } \\
\text { recebe acesso ilimitado e individual. Assim, o } \\
\text { mesmo bem é utilizado sequencialmente pelos } \\
\text { consumidores. }\end{array}$ & $\begin{array}{l}\text { Partilha de carros ou } \\
\text { outros veículos; }\end{array}$ \\
\hline & $\begin{array}{l}\text { Conjugação de bem tangível }- \text { o provedor } \\
\text { retém a propriedade do bem e, muitas vezes, é } \\
\text { responsável pela manutenção e reparo. O } \\
\text { consumidor paga taxas regulares, mas não } \\
\text { recebe acesso ilimitado e individual. Assim, o } \\
\text { mesmo produto é utilizado simultaneamente } \\
\text { pelos consumidores. }\end{array}$ & $\begin{array}{l}\text { Carros ou outros veículos } \\
\text { em uso conjugado; }\end{array}$ \\
\hline \multirow[t]{3}{*}{$\begin{array}{l}\text { PSS } \\
\text { orientado ao } \\
\text { resultado }\end{array}$} & $\begin{array}{l}\text { Pagamento por unidade de serviço - o bem } \\
\text { tangível ainda constitui a base do PSS, } \\
\text { contudo, o consumidor compra somente a } \\
\text { "saída" do produto de acordo com nível de } \\
\text { utilização. }\end{array}$ & $\begin{array}{l}\text { Carros ou outros veículos } \\
\text { alugados por "pagamento } \\
\text { por quilômetro". }\end{array}$ \\
\hline & $\begin{array}{l}\text { Resultado funcional }-\mathrm{o} \text { provedor } \mathrm{e} \text { o } \\
\text { consumidor acordam um resultado final, não }\end{array}$ & $\begin{array}{l}\text { Esquemas integrados de } \\
\text { mobilidade e serviços. }\end{array}$ \\
\hline & $\begin{array}{l}\text { sendo especificado como este será entregue. Os } \\
\text { bens utilizados para produzir o resultado } \\
\text { acordado são de posse e responsabilidade do } \\
\text { provedor. }\end{array}$ & \\
\hline
\end{tabular}

Fonte: Williams (2007), tradução do autor.

Williams (2007) aborda o ramo metal mecânico com o segmento automotivo, contudo, a bibliografia traz diversos exemplos que contribuem e ampliam o entendimento de como essa nova estratégia pode ser configurada. No entanto, as características do PSS utilizados nesta análise estão agrupadas na revisão bibliográfica específica. 


\subsubsection{VALOR NO PSS}

Toda oferta ao mercado possui um determinado valor agregado orientado a um grupo de consumidores. Nesse sentido os consumidores vêem o bem tangível e o serviço como um conjunto de atributos (WOODRUFF, 1997). O valor atribuído por esses consumidores resulta então de sua percepção com a avaliação geral dos atributos presentes no bem e no serviço (KOTLER, 1998), das consequências proporcionadas na utilização do bem (valor em uso) (WOODRUFF, 1997) ou das propriedades funcionais que determinam a utilidade de um serviço.Então, o "valor percebido" é dado pela percepção do consumidor do conjunto de benefícios (técnicos, econômicos e/ou sociais) referentes ao bem tangível e aos serviços frente a seus objetivos e necessidades em relação aos custos totais (em termos de valores monetários) demandados pela aquisição (compra do produto e/ou contratação dos serviços). O valor percebido é influenciado pelos desejos iniciais que o consumidor possui sobre tais atributos e consequências de uso para o atendimento de suas necessidades (a expectativa de valor) construído com base em seus valores e preferências pessoais frente à comparação com as ofertas similares ou concorrentes no mercado.

O conceito de valor também pode sofrer uma declinação referente à perspectiva de análise. No ponto de vista do stakeholder responsável pela produção ou prestação a relação com o consumidor resulta no valor entregue (ou fornecido). Nesse caso o valor é dado pela relação do conjunto de benefícios oferecidos por um bem tangível ou por uma função de serviço (constituída pelo conjunto de atividades) em função dos custos totais demandados para a produção do bem e para o desempenho das ações responsáveis pela função de serviço.

Portanto, nesta abordagem o valor no PSS do ponto de vista do consumidor final se refere ao conjunto de benefícios (técnicos, econômicos e/ou sociais) decorrentes dos atributos do bem tangível e do serviço. Os serviços podem então ser empregados para garantir uma disponibilidade de valor quando, por exemplo, o contrato de prestação do PSS inclui condições de manutenção. Podem também ser empregados para atender certas condições dessa disponibilidade, nos casos em que o consumidor paga pelo direito de uso do valor referente a um produto. Os serviços ainda podem ser empregados para viabilizar a logística da disponibilidade do valor com controles de uso, rastreamento e informação. Sob outra perspectiva o valor entregue pelo PSS também pode se apresentar sob a forma de um resultado no qual o artefato complementa a solução oferecida, dando condições à realização do resultado esperado pelo emprego do serviço. Portanto, se em um PSS o valor total é resultante do valor referente a um bem tangível $(X)$ adicionado do valor referente a um serviço $(Y)$, esse valor pode 
ser descrito como: a existência de $X$, quantidade de $X$, acesso à $X$, condição de $X$, direitos de uso de $X$, sendo $X=$ automóveis (como exemplo) (KIM et al., 2009). Esse valor também pode ser descrito como: deslocamento (sendo este o resultado acordado); mas estando, ainda, condicionado aos aspectos de $X$ (utilizando o exemplo de $X$ = automóveis). Por isso o conjunto de atributos disponibilizados pelo bem tangível, pelo serviço e/ou pela sua interação responsáveis pelos benefícios entregues é referido, nessa abordagem, como o pacote de valor.

Considerando ainda o valor sob uma perspectiva holística e observando a dinâmica do ciclo de vida o valor pode ser representado em uma estrutura sistemática. Essa estrutura não limita o valor a uma utilidade em função de um custo, mas incorpora a condição dinâmica de atuação podendo estabelecer um ciclo que busca o ajuste a um objetivo. A estrutura de criação de valor, representada na Figura 9, estabelece concordância com a perspectiva da organização por níveis sistêmicos, uma vez que cada um destes níveis pode apresentar tal dinâmica.

Figura 9 - Estrutura de criação de valor

Encontrar valor para as partes interessadas
Desenvolver e ter o acordo de todos os envolvidos em relação a abordagem

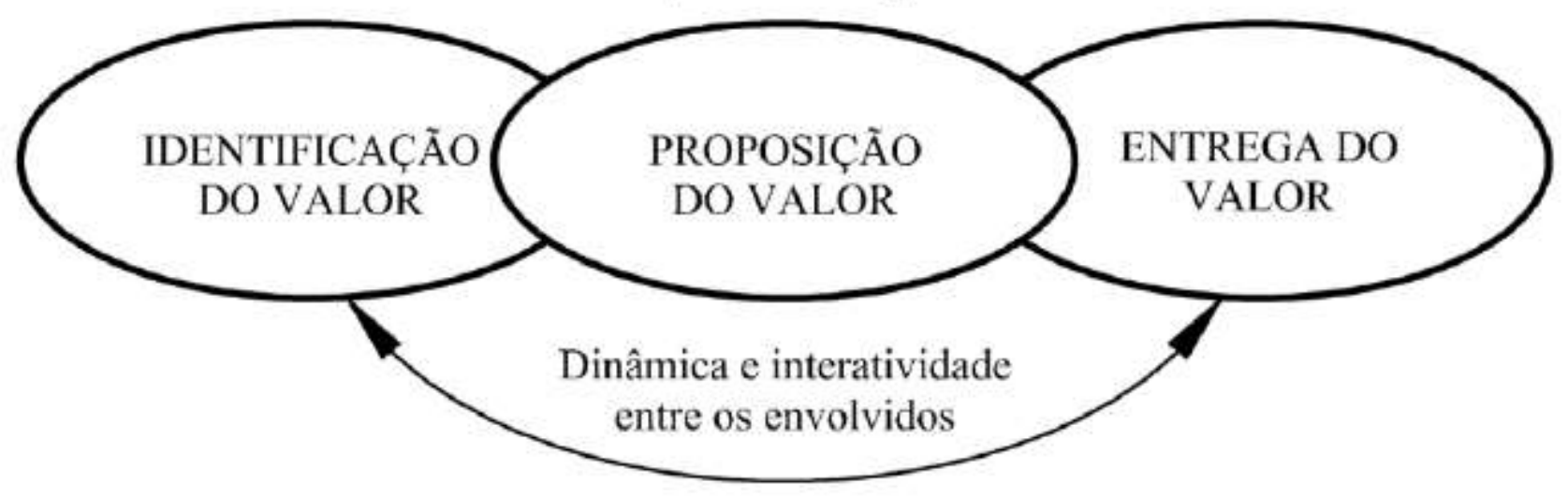

Fonte: Stanke e Murman (2002), tradução do autor.

Na estrutura de criação de valor a etapa de "identificação do valor" que corresponde à definição do valor de interesse que, em um nível de empreendimento, é referente aos stakeholders envolvidos (sendo que o consumidor final enquadra-se também neste nível). Para tal podem ser úteis: técnicas de pesquisa de mercado, reuniões entre os atores de interesse, análise de cadeia de valor, dentre outros. Já em um nível de operação, na realização do PSS, a identificação de valor pode se dar com a identificação da necessidade de uma determinada atividade não planejada e que complementaria a expectativa de valor do consumidor. A identificação acarreta a "proposição de valor" que engloba o 
desenvolvimento mútuo dos meios que viabilizem a entrega do valor identificado conforme as característica e dimensões do nível sistêmico. Pode corresponder à organização do PSS para atender aos diferentes grupos de consumidores, ou mesmo, a um grupo de trabalho, suas ferramentas e procedimento, destinado à execução de uma atividade de serviço. A proposição do valor está condicionada às possibilidades e interesses dos envolvidos, como também às legislações. $E$, a "entrega do valor" corresponde efetivamente à operacionalização do planejado. Pode corresponder, de acordo com o nível sistêmico em questão, à entrega do pacote de valor do PSS, ou operacionalmente, à entrega do valor em uso com a aplicação das atividades de serviço junto ao bem tangível.

Portanto, vista a abrangência de possibilidades de "benefícios" que um PSS pode proporcionar devido aos novos arranjos que podem ser desenvolvidos entre o bem tangível e o serviço, o emprego do conceito de valor auxilia o tratamento deste aspecto do PSS. Na fase de desenvolvimento a abordagem de valor pode ser utilizada para viabilizar a consideração dos benefícios adicionais dos serviços (MAUSSANG et al., 2007). Nesse sentido, em uma visão que dispõe o "valor" como o objetivo sistemático de uma dinâmica de identificação,proposição e entrega, a estrutura de "criação de valor" pode viabilizar ou facilitar esse tipo de abordagem ao PSS.

\subsection{CARACTERIZAÇÃO DO PSS PARA A ANÁLISE (FUNDAMENTAÇÃO TEÓRICA ESPECÍFICA)}

A fundamentação teórica específica reflete o estado atual do conhecimento acerca do tema e é utilizada para a composição da estrutura conceitual para o processo de modelagem. A caracterização do PSS tem base na literatura especializada vigente. Os artigos considerados necessários para caracterizar o PSS foram selecionados seguindo um processo estruturado de busca bibliográfica sistematizada. Os artigos identificados pelo processo e considerados no portfólio de artigos de referência contribuem para responder questões de pesquisa específicas para a composição da estrutura conceitual. Todos os detalhes da aplicação do processo estruturado e a busca bibliográfica sistematizada e uma bibliometria de tal portfólio podem ser vistos com Ariente Neto (2013). Contudo, o portfólio bibliográfico resultante é apresentado por completo no Quadro 5 . Neste também se salienta a principal contribuição de cada artigo para a análise. 
Quadro 5 - Portfólio bibliográfico de base para a análise

\begin{tabular}{|c|c|}
\hline Referência & Contribuições à análise \\
\hline $\begin{array}{c}\text { Aurich, Fuchs e } \\
\text { Wagenknecht (2006) }\end{array}$ & $\begin{array}{l}\text { Contribui com a representação do ciclo de vida no PSS e } \\
\text { evidencia fatores atuantes nesse. }\end{array}$ \\
\hline $\begin{array}{l}\text { Maxwell, Sheate e Van } \\
\text { Der Vorst (2006) }\end{array}$ & Auxilia na compreensão da configuração do ciclo de vida no PSS \\
\hline Morelli (2006) & $\begin{array}{l}\text { Auxilia na compreensão dos stakeholders envolvidos para o } \\
\text { sucesso da implantação do PSS. }\end{array}$ \\
\hline $\begin{array}{l}\text { Aurich, Schweitzer e } \\
\text { Fuchs (2007) }\end{array}$ & $\begin{array}{l}\text { Contribui com a representação do ciclo de vida no PSS e } \\
\text { evidencia fatores atuantes no sistema. }\end{array}$ \\
\hline $\begin{array}{l}\text { Evans, Partidário e } \\
\text { Lambert (2007) }\end{array}$ & $\begin{array}{l}\text { Fornecendo evidências empíricas dos fatores envolvidos no } \\
\text { sistema e da configuração da rede de atores. }\end{array}$ \\
\hline Aurich et al. (2009) & Contribui com a compreensão da estrutura exigida a um PSS. \\
\hline \multirow[t]{2}{*}{ Bianchi et al. (2009) } & $\begin{array}{l}\text { Avalia a dinâmica de implantação do PSS como estratégia de } \\
\text { mercado e a transição deste. São disponibilizados fatores (do }\end{array}$ \\
\hline & meio inserido) que influenciam o sistema. \\
\hline $\begin{array}{l}\text { Kimita, Shimomura e } \\
\text { Arai (2009) }\end{array}$ & $\begin{array}{l}\text { Fornece uma visão referente ao consumidor sobre os aspectos do } \\
\text { PSS que influenciam a satisfação com o valor entregue. }\end{array}$ \\
\hline $\begin{array}{c}\text { Rese, Karger e } \\
\text { Strotmann (2009) }\end{array}$ & $\begin{array}{l}\text { Contribui com a estruturação do PSS e com a consideração do } \\
\text { valor. }\end{array}$ \\
\hline $\begin{array}{l}\text { Abramovici, Bellalouna } \\
\text { e Göbel (2010) }\end{array}$ & $\begin{array}{l}\text { Fornece fatores responsáveis pelo desencadeamento do } \\
\text { comportamento dinâmico do PSS a nível operacional. }\end{array}$ \\
\hline $\begin{array}{l}\text { Ceschin e Vezzoli } \\
\qquad(2010)\end{array}$ & Contribui com a compreensão dos fatores de sucesso do PSS. \\
\hline $\begin{array}{l}\text { Richter, Sadek e Steven } \\
\qquad(2010)\end{array}$ & $\begin{array}{l}\text { Contribui com uma visão das consequências da extensão da rede } \\
\text { de criação de valor }\end{array}$ \\
\hline Geng et al. (2011) & $\begin{array}{l}\text { Auxilia no entendimento de como o PSS pode atuar na satisfação } \\
\text { do consumidor }\end{array}$ \\
\hline $\begin{array}{l}\text { Lelah, Mathieux e } \\
\text { Brissaud (2011) }\end{array}$ & Fornecendo dados empíricos da configuração da rede de atores. \\
\hline $\begin{array}{l}\text { Phumbua e Tjahjono } \\
\qquad(2011)\end{array}$ & $\begin{array}{l}\text { Contribui com uma síntese dos fatores que desencadeiam o } \\
\text { comportamento dinâmico do PSS. }\end{array}$ \\
\hline
\end{tabular}




\begin{tabular}{|c|l|}
\hline Wang et al. (2011) & $\begin{array}{l}\text { Propõe uma perspectiva de desenvolvimento modular do PSS } \\
\text { contribuindo como as considerações sobre a interação entre o } \\
\text { bem tangível e o serviço (e entre os stakeholders). }\end{array}$ \\
\hline $\begin{array}{c}\text { Yoon, Kim e Rhee } \\
(2012)\end{array}$ & $\begin{array}{l}\text { Contribui com o ponto de vista do consumidor na avaliação do } \\
\text { PSS. }\end{array}$ \\
\hline
\end{tabular}

Fonte: o autor.

Com isto está formada a base para a fundamentação específica conduzida na sequência.

\subsubsection{O CICLO DE VIDA DO PRODUTO NO CONTEXTO DO PSS}

A análise do ciclo de vida do produto no PSS se faz necessária, primeiramente para um posicionamento quanto à interação entre os stakeholders e, posterior e consequentemente para identificação dos principais fatores que influenciam o sistema. Esta análise é condicionada ao ponto de vista de análise uma vez que as etapas do ciclo de vida são nomeadas conforme o posicionamento da análise. Contudo, como o PSS engloba múltiplos

stakeholders, a análise do ciclo de vida pode ser conduzida em diferentes pontos de vista.

De forma mais abrangente certas contribuições do PSS (como o caso dos benefícios ambientais atribuídos a este sistema) somente seriam atingidas se o desenvolvimento do sistema atribuir relevância destas contribuições aos fabricantes, visto que na estratégia de atuação convencional no mercado (de simples venda de produtos) os benefícios financeiros são os motivadores fundamentais. Mesmo que o desenvolvimento do PSS considere a atuação em níveis do sistema que o conduzam a uma nova dinâmica a atuação dos fabricantes e prestadores ainda pode não ser suficiente. Frente a isto políticas públicas são vistas como necessárias para viabilizar empreendimentos desenvolvidos segundo a ótica do Sistema Produto-Serviço (MORELLI, 2006; BIANCHI et al., 2009; CESCHIN; VEZZOLI, 2010).

Políticas (econômicas) que estimulem a criação de condições encorajando os fabricantes a atuarem em um contexto de PSS, sensibilizem os consumidores dos benefícios de um consumo sem posse, e que promovam a disseminação de informações e conhecimento de suporte para as empresas (CESCHIN; VEZZOLI, 2010). Nestas considerações a condução da abordagem do ciclo de vida pode auxiliar a compreensão destes stakeholders (incluindo então o governo além dos fabricantes e prestadores) acerca da dinâmica do mercado com a "introdução" de empreendimentos baseados no Sistema Produto-Serviço. Isto devido à relevância da compreensão da necessidade de superação da 
inércia da introdução destes empreendimentos até a obtenção do equilíbrio do mercado, refletindo assim nas decisões acerca dos investimentos demandados a estes stakeholders (BIANCHI et al., 2009). Já para o contexto interno do fabricante as possíveis configurações do ciclo de vida do produto abordam as etapas necessárias para a realização do bem físico. Estas etapas iniciam com o desenvolvimento que mesmo exigindo a participação conjunta dos stakeholders em um processo de desenvolvimento integrado do bem tangível e dos serviços (AURICH; FUCHS; WAGENKNECHT, 2006; EVANS; PARTIDÁRIO; LAMBERT, 2007) permanece no

domínio das atribuições do fabricante devido a sua maior influência no projeto do produto (AURICH; FUCHS; WAGENKNECHT, 2006; EVANS; PARTIDÁRIO; LAMBERT, 2007;

AURICH et al., 2009). Nesta etapa estão concentradas as decisões estratégicas relacionadas a toda constituição e dinâmica do PSS, sendo que, somente quando concluída e estando todos os envolvidos de total conhecimento e acordo com suas atribuições o PSS seguirá propriamente para sua "realização". Na realização do PSS o fabricante então é responsável propriamente pela fabricação do artefato físico, ou seja, pelos processos, competências, recursos e demais demandas necessárias às etapas envolvidas nesta fabricação. Aqui se situamos estágios de desenvolvimento de fornecedores, aquisição de matéria-prima, fabricação dos componentes, controle de qualidade, montagem, teste, remanufatura, entre outras específicas ao PSS desenvolvido.

Ainda em relação à realização do PSS, contudo considerando o prestador dos serviços, a perspectiva do ciclo de vida volta-se então as etapas necessárias para a execução dos serviços projetados no desenvolvimento do PSS. Como tal, esses serviços e sua interação com o artefato físico se destinam à entrega da funcionalidade requerida. Dessa maneira o ciclo de vida abordado pode ser constituído das etapas de preparação e execução dos serviços, coleta de dados para melhoria dos processos, interação com o fabricante, entre outras. No caso de serviços técnicos podem ser citados como associados aos produtos a manutenção, atualização, adaptação, recondicionamento, treinamento do usuário e a melhoria de processos (AURICH; FUCHS; WAGENKNECHT, 2006). Porém, cada caso de PSS pode demandar serviços específicos como, por exemplo, os serviços de venda ou logística.

A etapa de execução dos serviços é de grande importância para o sucesso do PSS, visto que é nesta execução que ocorre a interação com o consumidor. Como consequência a atribuição de valor do consumidor (e sua aprovação) interfere diretamente na aceitação dos módulos de serviço e na condução do PSS como um todo (KIMITA; SHIMOMURA; ARAI, 2009). Devido a isto o consumidor final 
também é visto como um importante stakeholders envolvidos no PSS (BIANCHI et al., 2009; KIMITA; SHIMOMURA; ARAI, 2009),

inclusive ainda na etapa de desenvolvimento uma vez que o contexto social e cultural no qual o PSS se insere influencia na dinâmica deste sistema (MORELLI, 2006). Portanto, sua perspectiva quanto ao ciclo de vida do produto também precisa ser considerada, sendo que esta é constituída fundamentalmente pelas etapas referentes à aquisição (incluindo a própria decisão de aquisição), utilização (podendo ser desmembrada em etapas específicas conforme o desenvolvimento do PSS e sua consideração das necessidades específicas do consumidor) e descarte (AURICH et al., 2009). Contudo, como particularidade do PSS devido à adição dos serviços aos bens tangíveis e da flexibilidade de fornecimento destes serviços o Sistema Produto-Serviço possibilita o atendimento a necessidades específicas de grupos de consumidores (AURICH; FUCHS; WAGENKNECHT, 2006; EVANS; PARTIDÁRIO;

LAMBERT, 2007; AURICH et al., 2009). Ou seja, é a perspectiva das necessidades específicas de cada grupo de consumidor que determina os ciclos de vida correspondentes a estes; ou os objetivos e limites do sistema de prestação (KIMITA; SHIMOMURA; ARAI, 2009). Assim, as diferentes composições dos ciclos de vida atendendo a necessidades específicas atribuem ao PSS sua característica de personalização do atendimento das necessidades.

A Figura 10 representa uma possível caracterização dos ciclos de vida conforme os pontos de vista relacionados aos stakeholders citados. Entretanto, essa ilustração não busca prescrever a constituição destes ciclos de vida uma vez que cada uma das etapas citadas pode ser subdividida em sobcapas constituindo, em si só, uma análise em um nível sistêmico abaixo. Mas, estabelece uma visão abrangente das possíveis considerações do ciclo de vida em função dos diferentes níveis sistêmicos que o PSS é composto. 
Figura 10 - Desdobramento do ciclo de vida do produto conforme o ponto de vista dos stakeholders

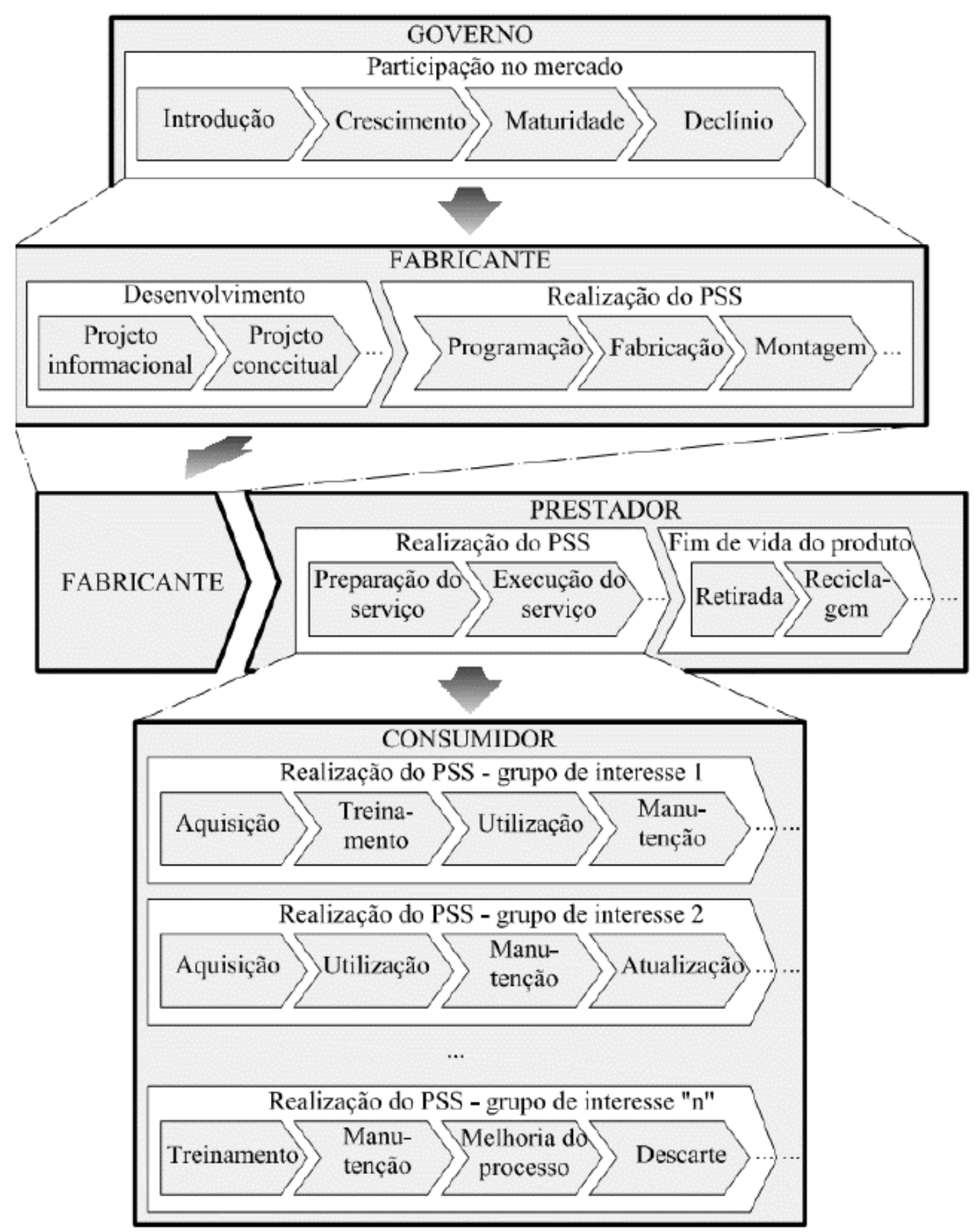

Fonte: o autor.

Fundamentalmente, para esta análise, o desdobramento apresentado na Figura 10 representa as perspectivas dos ciclos de vida do produto direcionadas à entrega do valor para os grupos de interesse que consistem nos consumidores finais. Nesse sentido a configuração específica do ciclo de vida 
direcionado a um determinado grupo de interesse engloba módulos de serviços específicos influenciando na organização do PSS.

\subsubsection{ORGANIZAÇÃO DO PSS}

Uma vez exploradas as possíveis configurações do ciclo de vida do produto no Sistema Produto-Serviço uma definição sobre a organização entre os envolvidos neste sistema da sequência à condução do abordagem. A organização refere-se ao arranjo necessário para a produção dos bens e prestação dos serviços, como tal, depende de como os bens tangíveis e serviços podem ser configurados e associados.

Na configuração do bem tangível, visando sua associação aos serviços, a estratégia de plataformas representa um importante facilitador. A estratégia de plataforma consiste no desenvolvimento de um artefato (ou partes do artefato) cuja arquitetura permita variações (EVANS; PARTIDÁRIO; LAMBERT, 2007; WANG et al., 2011). Traçando um paralelo com a estratégia de mercado convencional baseada na simples venda de produtos um segmento que explora a concepção de produtos conforme a estratégia de plataforma é o segmento automotivo. Neste segmento o projeto do produto é realizado de forma que alguns componentes principais sejam comuns a mais de um modelo de automóvel como é, por exemplo, o componente "chassi". Ou seja, muitos modelos de automóveis compartilham o mesmo componente em suas configurações de montagem sendo, no entanto, produtos direcionados a segmentos de mercado distintos ou que atendem necessidades diferenciadas dos consumidores. Mas nestes casos de fabricantes convencionais a estratégia de plataforma é utilizada como recurso para implementação de estratégias organizacionais não necessariamente envolvendo outras organizações (EVANS; PARTIDÁRIO; LAMBERT, 2007). No PSS essa estratégia é utilizada com o objetivo de agregar aos bens tangíveis componentes (ou módulos) de serviços (o conjunto de serviços que resultam no ciclo de vida direcionado ao grupo de interesse).

Nesse sentido, as configurações dos serviços sendo realizadas de forma a se estabelecer a interação com o bem tangível tornam o PSS capaz de fornecer uma ampla gama de soluções. Dessa forma a consideração acerca dos serviços nesta abordagem considera (como observado anteriormente) um elemento do sistema potencialmente entregue por diferentes atores e integrados pela arquitetura de plataforma. A estratégia de plataforma estando associada aos módulos de serviços possibilita estabelecer um arranjo integrando múltiplos atores na rede de prestação destes serviços aumentando, assim, "extensão da cadeia de valor". Com isso, diferentemente dos produtos que são 
fabricados em um determinado momento (como um evento do sistema), os serviços são entregues sucessivamente ao longo do ciclo de vida (AURICH; FUCHS; WAGENKNECHT, 2006). Então a atuação ou não atuação de um dos atores deste arranjo (ou seja, a entrega ou não de um serviço) que corresponde a uma etapa do ciclo de vida do PSS diferencia os ciclos de vida. Isto determina, por sua vez, quais e quantos grupos de interesse específicos serão atendidos pelos ciclos de vida individuais.

A Figura 11 representa a organização de um PSS genérico conforme as considerações explicitadas. Os diferentes ciclos de vida mostrados suprem as necessidades específicas dos grupos de consumidores, representados pelo "PSS1" e "PSS2. O fluxo de bens tangíveis tem origem com o fabricante, sendo distribuídos aos diferentes grupos. Neste fluxo de bens incidem os serviços em suas sequências determinando os ciclos de vida, cujas etapas nesta representação correspondem aos módulos de serviços. Assim, os diferentes ciclos de vida diferem entre si pelos módulos de serviço agregados a estes. Esses módulos de serviços resultam dos fluxos de serviços representados com origem na rede de prestação, sendo que, nesta figura o prestador é representado de forma individual (um provedor para cada módulo de serviço), contudo é possível que diferentes serviços sejam entregues pelo mesmo prestador (na mesma unidade ou por diferentes unidades operacionais). Ainda, outra característica evidenciada na Figura 11 consiste em que a realização (ou entrega) dos serviços ocorre, muitas vezes, com a interação e participação do consumidor. Proporcionada por esta interação também é representado um fluxo de informação de feedback com a rede de prestação e de interação com o fabricante. Este fluxo de informação é estabelecido pela infraestrutura do sistema (LELAH; MATHIEUX; BRISSAUD, 2011) e possibilita a adequação desse sistema. 
Figura 11- Organização do PSS

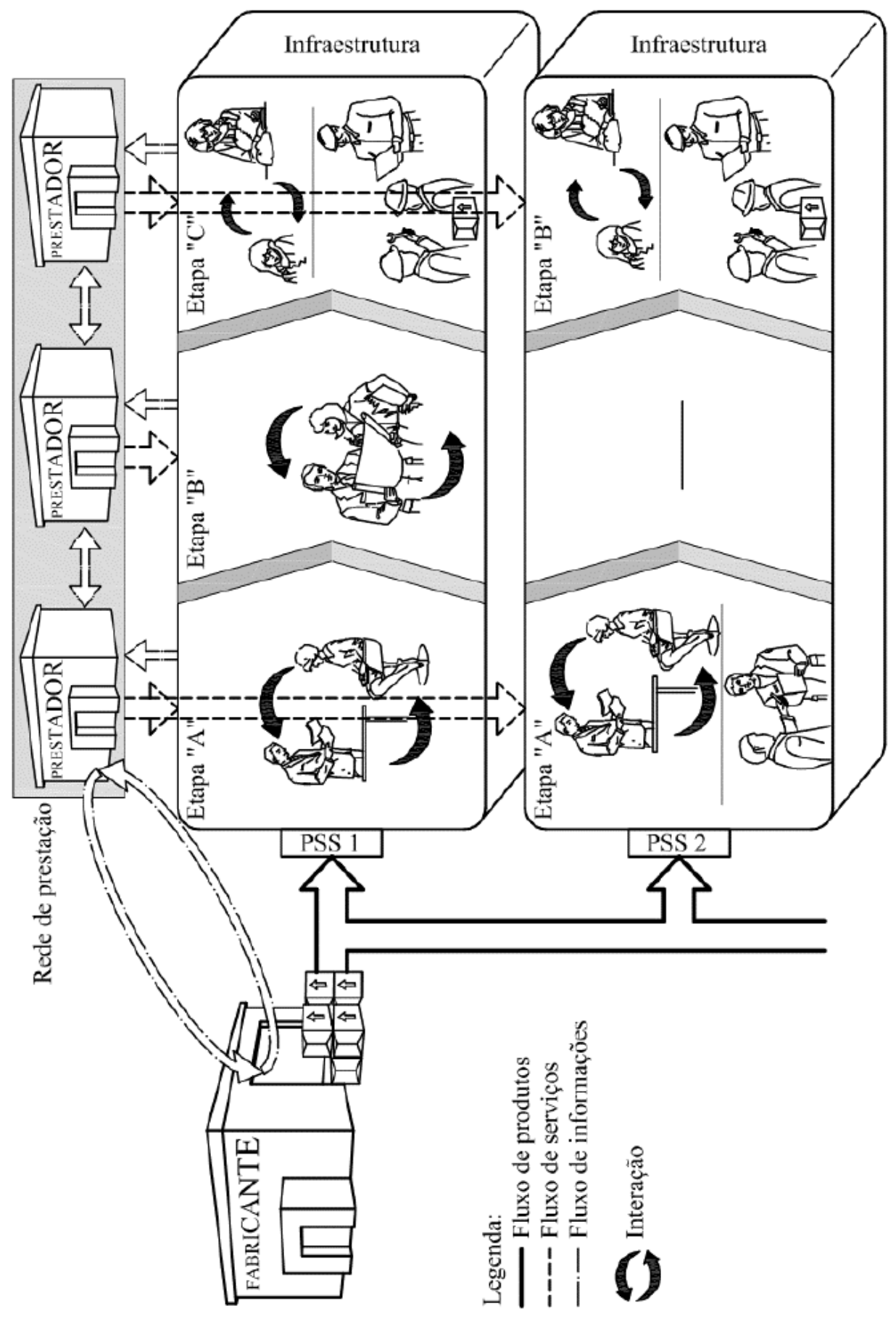

Fonte: o autor.

Fundamentalmente na Figura 11 é representado que o sistema de produção está associado ao sistema de prestação de serviços. Pelo ponto de vista do fabricante seja por um único ciclo de vida ou por uma "diversificação do valor" entregue por diferentes ciclos de vida. No ponto de vista do prestador a demanda pelo serviço associado ao bem tangível também pode ser dado de diferentes formas. Como exemplo na consideração de serviços técnicos, um serviço de treinamento demanda uma determinada 
quantidade de horas de prestação por produto potencialmente entregue em uma única prestação por consumidor. Já um serviço de manutenção poderia tem um "regime" de entrega que exija a reaplicação do serviço em um intervalo de tempo, distribuindo a capacidade de atendimento do prestador desse serviço em relação à quantidade de consumidores utilizando o sistema e favorecendo uma demanda mais constante ao prestador.

Ainda sob essa perspectiva mesmo um único ciclo de vida pode resultar em configurações específicas em relação à extensão da rede de criação de valor. Assim, nessa abordagem são exploradas as implicações da agregação de um módulo de serviço genérico, desenvolvendo uma visão geral dessa associação. A relação entre a dinâmica de produção e prestação pode ser generalizada pela "quantidade de horas de prestação de serviços" necessária a um módulo específico de serviço por "unidade de bens tangíveis" utilizados pelo sistema. Ou ainda, ao invés de "unidades de bens" determinados sistemas podem requerer a utilização de "tempo de uso do produto" ou "quilômetro percorrido" ou outras unidades referentes à utilização do bem (AURICH; SCHWEITZER; FUCHS, 2007).

\subsubsection{ASSOCIAÇÃO ENTRE OS ELEMENTOS DE BEM TANGÍVEL E SERVIÇO}

Vista a organização que integra o fabricante ao prestador e a possibilidade do atendimento pelo PSS a diferentes necessidades de grupos de consumidores o foco deste tópico recai na interação entre os elementos de bem tangível e de serviço. A interação ou participação do consumidor na prestação dos serviços condiciona a aceitação do PSS à obtenção do estado de satisfação ${ }^{15}$ desse consumidor (BIANCHI et al., 2009; KIMITA; SHIMOMURA; ARAI, 2009). Portanto a interação com o consumidor tem na passagem de um estado inicial do receptor para um determinado estado desejado (o estado de satisfação) para que os serviços sejam considerados aceitos (KIMITA; SHIMOMURA; ARAI, 2009; YOON; KIM; RHEE, 2012). A disciplina de engenharia de serviços aborda as condições em que tal interação é efetuada quando da prestação.

Conforme a engenharia de serviços o estado de satisfação do consumidor é representado pelo "parâmetro de estado do receptor"16 (KIMITA; SHIMOMURA; ARAI, 2009). Como os serviços podem ser constituídos de várias atividades e cada uma contando ainda com seus procedimentos específicos e desempenho planejado, cada serviço pode ser representado por um conjunto de parâmetros de estado do receptor. Em vista disto, uma etapa de suma importância no desenvolvimento de serviços consiste na coleta e tratamento dos dados que refletem os desejos e preferências dos grupos de consumidores alvo. Ou seja, os parâmetros de estado do receptor estão relacionados aos requisitos 
dos consumidores. Nesse sentido são empregadas ferramentas específicas para a identificação dos requisitos (e da qualidade requerida para esses requisitos) buscando, por vezes, envolver o próprio consumidor ainda no processo de desenvolvimento do PSS.

Para a condução do receptor para um estado de satisfação cada parâmetro de estado do receptor é influenciado pelo "conteúdo do serviço" (CoS) e pelos "canais de serviço" (CaS) (KIMITA; SHIMOMURA; ARAI, 2009). O "conteúdo do serviço" influencia os parâmetros de estado do receptor de forma direta e pode envolver materiais, energia ou informações (KIMITA; SHIMOMURA; ARAI, 2009) entregues por ações, esforços ou desempenho. Os "parâmetros de conteúdo" definem, então, o conteúdo de cada serviço. Contudo, os serviços precisam ser transferidos, amplificados e controlados, sendo essas as atribuições dos canais de serviços. Dessa maneira, os canais de serviços influenciam os parâmetros de estado do receptor indiretamente e são definidos pelos "parâmetros de canal". A Figura 12 representa pictoricamente o conteúdo e o canal de serviço sob a percepção do receptor e seu objetivo de conduzir esse receptor a um estado de satisfação.

Figura 12 - Influência do conteúdo e dos canais de serviço na satisfação do receptor
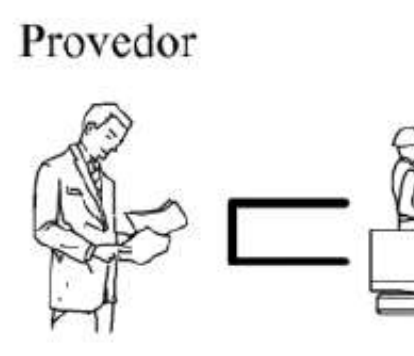

$\operatorname{CoS}$

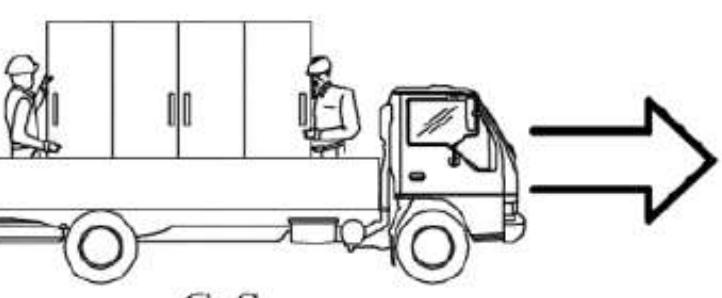

$\mathrm{CaS}$

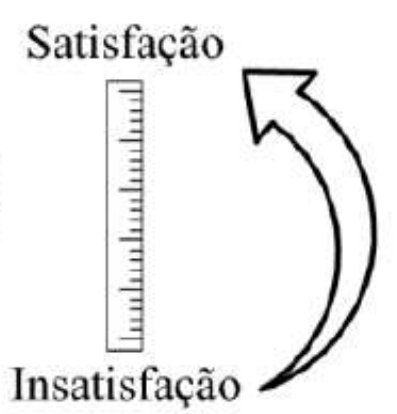

Fonte: Kimita, Shimomura e Arai (2009).

As várias funções que integram cada conteúdo e canal de serviço são dadas pelos "parâmetros funcionais" (PF). Logo, os PFs que influenciam diretamente os parâmetros de estado do receptor pertencem ao conteúdo do serviço, enquanto os PFs dos canais de serviço influenciam os parâmetros do consumidor indiretamente. Para esses parâmetros são elencados as questões referentes à qualidade englobando considerações referentes a custos, restrições físicas, posição do serviço no mercado e viabilidade do provedor (KIMITA; SHIMOMURA; ARAI, 2009).

Esses parâmetros, por sua vez, podem ser convertidos em requisitos funcionais referentes tanto ao bem tangível quanto ao serviço. O domínio da função envolve a inter- relação entre as funções do artefato e as funções do serviço (GENG et al., 2011). Nessa linha os requisitos provêem ao 
desenvolvimento do bem tangível a orientação de modo que as características desse produto (geométricas, dimensionais, estéticas, dentre tantas) contemplem e atue nos parâmetros funcionais, tanto os originados pelos parâmetros de conteúdo quanto de canal. E, são por esses "requisitos funcionais" que as soluções de projeto podem levar o produto a intervir nas "variáveis de processo" do PSS. Essa breve descrição ilustra como um processo pode conduzir as preferências do consumidor até os requisitos e parâmetros que definem as funções do artefato físico e do serviço (de modo direto pelo conteúdo ou indireto pelos canais de distribuição de serviços) e sua influência nas variáveis de processo. A Figura 13 ilustra esse processo de transformação de informações direcionado a relacionar os elementos de bem tangível e serviço no PSS.

Figura 13 - Processo de transformação da informação no desenvolvimento do PSS.

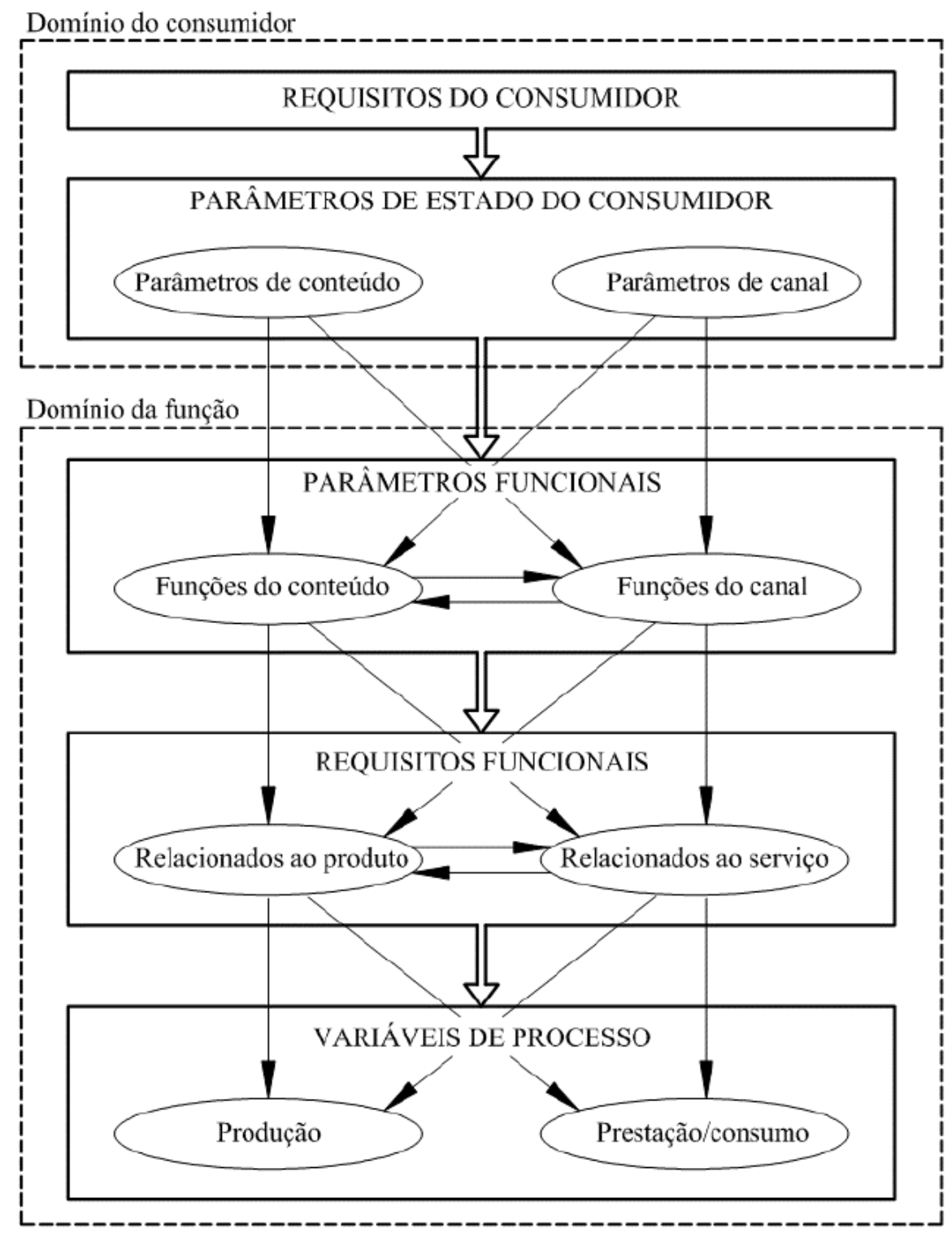

Fonte: Elaborado com base em Kimita, Shimomura e Arai (2009) e Geng et al. (2011). 
Conjuntamente à obtenção das informações em níveis coerentes às atividades no processo de desenvolvimento a correlação dos requisitos funcionais com o fator "qualidade" e seus custos exigidos complementa a abordagem com foco no valor entregue pela associação do bem com o serviço. Muitas abordagens focam nos aspectos referentes à qualidade do produto. Também abordagens específicas fazem referência ao tratamento da qualidade em serviços ${ }^{17}$ e sua influência no consumidor. $E$, também como já mencionado, ferramentas voltadas à mensuração da qualidade englobando o artefato físico e o serviço nos estágios de desenvolvimento do PSS também são disponibilizadas pela bibliografia especializada. Nessa linha de argumentação esses são os principais fatores que influenciam o estado de satisfação do consumidor no PSS.

Essa perspectiva de abordagem para associação entre esses elementos do sistema complementa o conduzido até então nesta fundamentação. Mas, ainda na sequência é explorada como se dá a dinâmica do Sistema Produto-Serviço.

\subsubsection{DINÂMICA DO PSS}

A etapa de realização do PSS é caracterizada pelo dinamismo do comportamento do sistema, uma vez que está sujeito às interferências externas (ABRAMOVICl; BELLALOUNA; GÖBEL, 2010; PHUMBUA; TJAHJONO, 2011). Esse dinamismo é uma

condição intrínseca aos sistemas e se faz presente no PSS adequando sua configuração planeja para uma configuração condizente as condições efetivamente exigidas com a atuação no mercado. Por consequência, a capacidade de adaptação do sistema é a condição tanto para uma rápida quanto para uma melhor resposta para as mudanças do ambiente.

Essa característica dinâmica do PSS se apresenta, inclusive, em diferentes níveis sistêmicos como é ilustrado na Figura 14 que representa o PSS simplificadamente pelo nível sistêmico operacional e estratégico. Conforme essa figura a adaptação operacional concentra- se na execução das atividades do PSS, assim como a adaptação estratégica envolve um replanejamento e a revisão do projeto; sendo que, externa ao sistema a adaptação estratégica envolve a reanálise da viabilidade das condições de adequação ao meio. Mas, a Figura 14 também indica que a característica dinâmica de realimentação de informações responsável pela adaptação do sistema a um nível operacional reflete-se também no nível estratégico, podem influenciar os fatores específicos deste nível e, dessa forma, promover uma adequação a uma nova condição. 
Figura 14 - A dinâmica do PSS nos níveis sistêmicos.

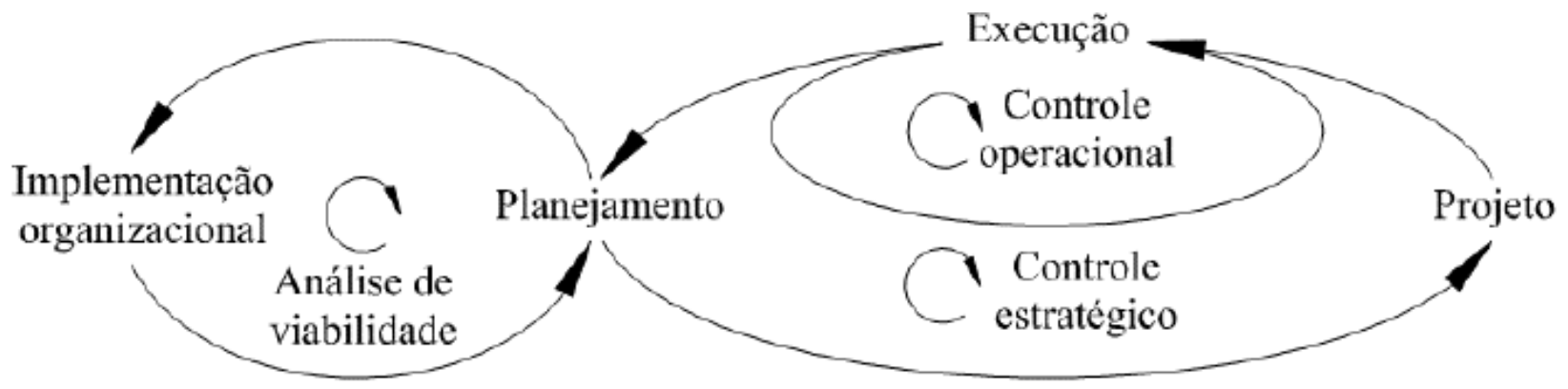

Fonte: Adaptado de Aurich; Schweitzer e Fuchs (2007).

Dessa maneira, cada nível sistêmico do PSS apresenta um comportamento o dinâmico de identificação, proposição e entrega de valor. Contudo esse comportamento é diferenciado em cada nível, pois está sujeito estruturas e fatores atuantes (tanto internos ao sistema quanto externos) específicos (podendo perfeitamente um nível sistêmico superior influenciar um nível inferior, como o estratégico ao operacional e vice-versa). Mas isto também se deve a questão temporal do paradigma sistêmico, visto que o tempo decorrente entre a ação gerada e a consequência observada difere nos níveis hierárquicos. Portanto, se faz necessário abordar especificamente os aspectos de interesse para a análise dinâmica do PSS.

Essa abordagem sobre a dinâmica do PSS completa a fundamentação teórica específica. O tópico seguinte tem base no que foi abordado nessa fundamentação expondo os subsistemas, em uma linguagem condizente com os termos da Dinâmica de Sistema, e salientando os fatores de influência a serem utilizados na modelagem.

\subsubsection{SUBSISTEMAS E PRINCIPAIS INTERAÇÕES}

Concatenando o abordado nesta fundamentação específica e delimitando a análise acerca do PSS são ressaltados principais subsistemas envolvidos na agregação de serviços aos bens tangíveis. Para tal, sob a perspectiva do fabricante a agregação de serviços aos bens implica na extensão do ciclo de vida tradicional por uma rede de extensão de criação de valor. Nesta rede atuam os prestadores de serviços em um arranjo de maneira a complementar o pacote de valor a ser entregue com a parte intangível desse valor. A aceitação dos serviços e, portanto, do pacote de valor entregue pelo PSS, está condicionada a condução do consumidor do serviço a um "estado de satisfação". Com isso, a interação entre esses três stakeholders (fabricante, prestador e consumidor) delimita as fronteiras desta análise. Ou seja, para esta análise específico a integração de serviços ao bem tangível é abordada englobando 
três subsistemas denominados: produção, prestação e consumo. Esses subsistemas são apresentados na Figura 15 conforme a visão sistêmica. Nesta consideração, o comportamento no tempo do sistema é dado pela interação entre esses três subsistemas atuando para a criação e entrega (e consumo) do pacote de valor. A Figura 15 representa simplificadamente essas interações entre os subsistemas (1 a 6), a influência do meio externo (7) e a própria influência dos fatores internos (8) ao sistema na dinâmica resultante.

Figura 15 - Subsistemas e interações

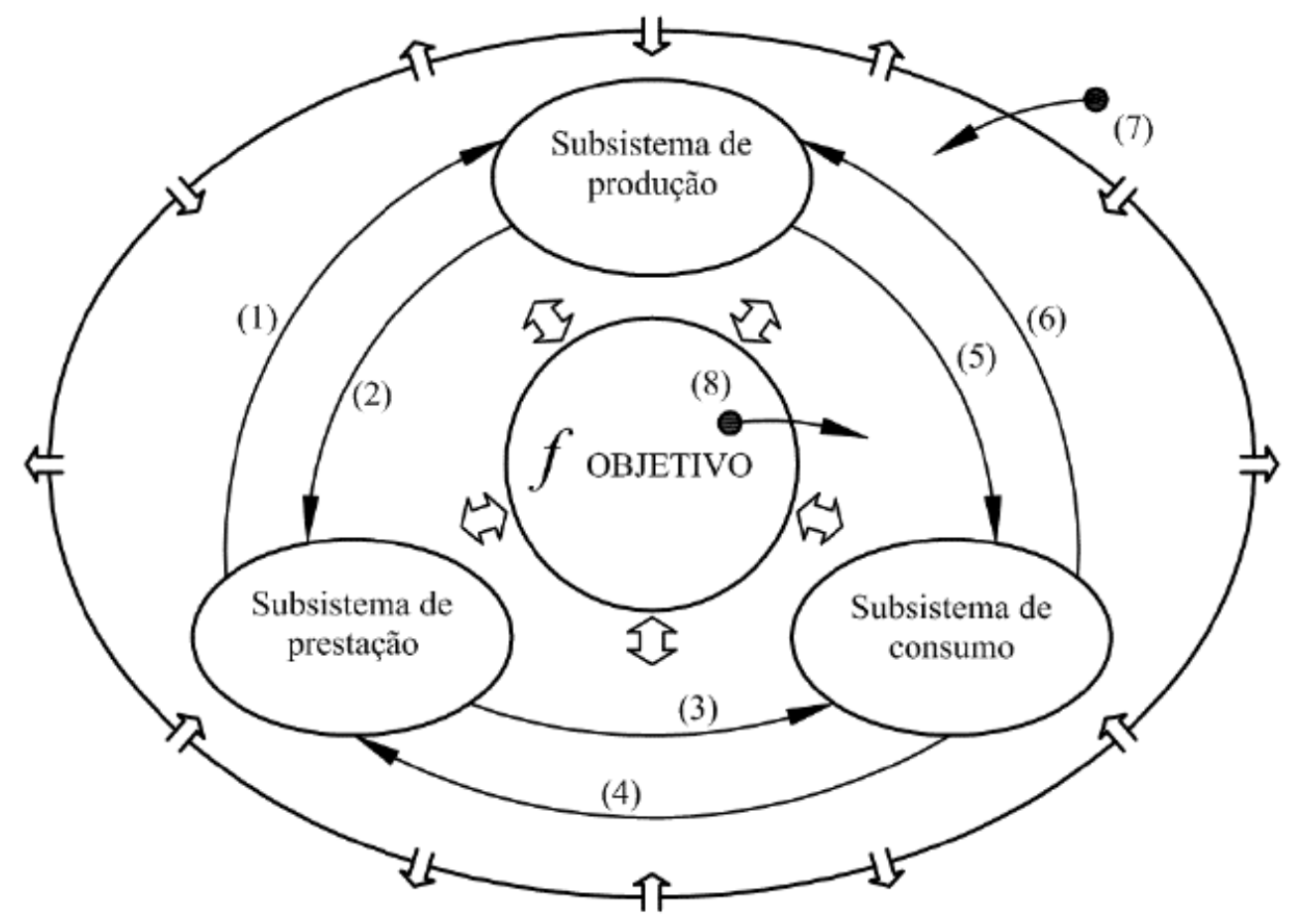

Fonte: o autor.

Na sequência cada subsistema é descrito de modo a expor de que se constitui e o que representa para o sistema. Após a explanação acerca dos subsistemas são abordadas as interações ressaltadas (conforme o Quadro 6).

\subsubsection{SUBSISTEMA DE PRODUÇÃO}

Essa análise é direcionada a compreensão do contexto ao qual o produto é inserido quando o fabricante atua em um Sistema Produto-Serviço com o intuito de prover subsídio ao desenvolvimento desse produto. Contudo, pela diversidade e flexibilidade característica dos serviços o PSS pode apresentar uma abrangência tal que compreenda um extremo no qual o emprego do artefato físico 
pode se dar somente como suporte as atividades de serviço. Nestes casos o desenvolvimento do produto ainda pode ser especifico a dinâmica do PSS, demandando também considerações no desenvolvimento referentes a tal contexto, visto que mesmo nestes casos o valor total entregue pelo PSS também está condicionado ao bem tangível. Porém, pode não apresentar uma demanda ao sistema produtivo capaz de inserir o fabricante no contexto de atuação, sendo então as atividades de serviço o único foco na "dinâmica" da entrega de valor. Essa condição de demanda ao sistema produtivo independe da orientação do PSS. Mesmo em um PSS orientado ao resultado (geralmente havendo um emprego mais intenso dos serviços) as decisões estratégicas que orientam o início do desenvolvimento do PSS podem induzir uma demanda ao sistema produtivo incorporando o fabricante na dinâmica de realização do PSS. Ou seja, mesmo em sistemas que o uso do produto se faz, por exemplo, de forma compartilhada e a venda se dá por unidade de uso a agregação de um maior número de usuários sustenta a demanda ao sistema produtivo. São nestas situações em que o sistema produtivo "alimenta" a estrutura de entrega de valor do PSS com o fornecimento contínuo de artefatos e/ou partes deste (como elementos de reposição) que o fabricante está sujeito aos reflexos do ciclo de vida pela influência dos serviços de forma significativa no sistema produtivo. Assim, esse trabalho com foco no fabricante contempla esse stakeholder a partir das novas condições que se apresentam uma vez que o sistema produtivo está sujeito a condições não comuns em uma situação de atuação orientada ao artefato puro.

Nesta abordagem o subsistema de produção engloba a energia, as instalações, máquinas, equipamentos, e toda a infraestrutura demandada, os materiais, componentes e/ou insumos consumidos pelo sistema, as tecnologias exigidas, as competências necessárias, bem como processos e políticas de controle. Portanto, o sistema produtivo consiste em todos os elementos atuantes, assim como todos os recursos requeridos visando a confecção dos bens tangíveis (como a parte tangível da entrega de valor) e sua disponibilização para a utilização no PSS. Nesse contexto também se situam os serviços internos necessários ao suporte das funções de manufatura que não são abordados diretamente. A atuação do fabricante é contextualizada por evidencias empíricas como com Evans; Partidário e Lambert (2007), e abordada também em processos de desenvolvimento como com Aurich; Fuchs e Wagenknecht (2006) e Aurich et al. (2009).

\subsubsection{SUBSISTEMA DE PRESTAÇÃO}

O sistema de prestação se refere aos elementos que viabilizam e realizam a entrega regulamentar do valor proposto pelo PSS na extensão do ciclo de vida. Por isso realizam os serviços planejados para o 
ciclo de vida em conjunto com o bem tangível. No ponto de vista estabelecido da estrutura do PSS o subsistema de prestação complementa o subsistema de produção pela adição da parte intangível do valor decorrente das atividades, ações e desempenho. Essas podem acompanhar o produto como pode ser visto com Evans; Partidário e Lambert (2007), ou se utilizar dele para entregar uma função ou produzir um resultado como exemplificado por Lelah; Mathieux e Brissaud (2011). No caso da ocorrência da interação com o consumidor no PSS, seja o consumidor final ou um ator integrante de uma cadeia de suprimento (em B2B) isto se dá pelo subsistema de prestação.

Esse subsistema pode englobar equipamentos de apoio e/ou materiais que podem ser consumidos no processo de prestação de serviços como, por exemplo, ferramentas empregadas e mesmo os produtos lubrificantes aplicados em um procedimento de manutenção. Esses são chamados de "bens facilitadores" e não compõem o produto propriamente do PSS. Também concentra as instalações, sua quantidade e localização, os recursos e competências, políticas, processos, procedimentos. Portanto, o subsistema de prestação complementa o subsistema de produção por meio dos elementos atuantes e dos recursos requeridos visando à entrega do valor.

\subsubsection{SUBSISTEMA DE CONSUMO}

Juntamente ao emprego das atividades de serviço está no subsistema de consumo a atribuição da condição de aceitação dos serviços e, como tal, do valor entregue pelo PSS. Engloba, portanto, os aspectos relacionados à como se dá a percepção do consumidor quanto ao valor entregue pelo PSS e determina seu estado de satisfação. Nessa percepção atuam então o serviço com suas características específicas e o bem tangível. Dessa maneira, a satisfação do consumidor não está baseada somente nos atributos funcionais, estéticos, ergonômicos (e demais atributos) como também nas características dos serviços. O bem tangível, por sua vez, pode intervir tanto no conteúdo do serviço quanto nos canais de transferência, amplificação ou entrega deste conteúdo.

Assim, a inclusão do subsistema de consumo na análise do contexto do PSS é necessária. Ademais a consideração deste subsistema é possível uma vez que a satisfação é mensurável por ferramentas específicas, tornando possível aos desenvolvedores, não somente identificarem os parâmetros que influenciam na satisfação do consumidor, como também estimar a qualidade requerida a cada característica do serviço e do bem tangível orientada pelos parâmetros de estado do receptor. 


\subsubsection{INTERAÇÕES ENTRE OS SUBSISTEMAS}

São identificadas preliminarmente conforme a fundamentação as principais interações entre os subsistemas e a influências dos meios internos e externos. Dessa maneira, é estabelecida uma referência aos processos de construção da estrutura do sistema pelas etapas de modelagem. Assim, complementando a estrutura do sistema mostrada na representação simplificada da Figura 15, o Quadro 6 relaciona as principais interações entre os subsistemas. Nesse quadro a numeração das interações, para a correta compreensão e associação com a Figura 15, é coincidente com a mostrada graficamente na figura. Essas relações ressaltadas entre os subsistemas são abordadas especificamente nas etapas de construção do modelo.

Portanto, segundo a perspectiva de análise a principal fator de desencadeamento da atuação mútua entre os subsistemas de consumo e produção, exercendo a necessidade de modificação no estado ou desempenho desses subsistemas, ocorre devido à demanda pelos elementos (6a) (4a). Essa atuação mútua se dá com o subsistema de produção no suprimento do consumo de bens tangíveis e, portanto, fornecendo ao sistema a "disponibilidade do valor" (2). Dessa maneira a disponibilidade do valor se refere à existência de tal bem referente ao pacote de valor entregue pelo PSS para o atendimento a uma demanda por produtos. Já o subsistema de prestação atua junto ao subsistema de produção para realizar a "adição de valor ao bem tangível" (1) para o complemento do pacote oferecido pelo sistema.

Quadro 6 - Principais influências na interação entre os subsistemas

\begin{tabular}{|l|l|}
\hline \multicolumn{1}{|c|}{$\begin{array}{c}\text { Interação entre os } \\
\text { subsistemas }\end{array}$} & \multicolumn{1}{c|}{$\begin{array}{c}\text { Principais fatores de influência na interação entre os } \\
\text { subsistemas e o ambiente }\end{array}$} \\
\hline (1) Prestação/produção & Adição de valor ao bem tangível \\
\hline (2) Produção/prestação & Disponibilidade de valor \\
\hline (3) Prestação/consumo & Entrega do valor referente ao serviço \\
\hline (4a) Consumo/prestação & Demanda por serviços \\
\hline (4b)Consumo/prestação & Percepção de valor \\
\hline (5) Produção/consumo & Valor referente ao bem tangível \\
\hline (6a) Consumo/produção & Demanda por bens tangíveis \\
\hline (6b)Consumo/produção & Percepção de valor \\
\hline & \\
\hline (7) Influência externa & Fatores de influência na expectativa de valor \\
\hline (8a) Influências internas & Fatores operacionais e de controle \\
\hline
\end{tabular}




\begin{tabular}{|l|l|}
\hline (8b)Influências internas & Intervenção na qualidade do bem tangível \\
\hline (8c) Influências internas & Intervenção na qualidade do serviço \\
\hline
\end{tabular}

Fonte: o autor.

A interação específica entre os subsistemas de prestação e consumo pode ser vista pela "entrega do valor referente ao serviço" (3), atividade de atribuição do subsistema de prestação. Essa entrega está sujeita à "percepção do valor" (4b) que, por sua vez, é atribuída ao subsistema de consumo. Essa é a principal interação entre a prestação e o consumo abordada para a agregação de serviços aos bens tangíveis frente à condução desta análise. Da mesma maneira a interação entre os subsistemas de produção e consumo ocorre com a produção fornecendo o "valor referente ao bem tangível" (5). 0 valor referente a este elemento também está sujeito a "percepção de valor" (6b).

Adicionalmente, como também está representado na Figura 15 tanto o ambiente interno quanto o ambiente externo exercem influências na dinâmica do sistema. Referente ao ambiente interno questões referentes às decisões das etapas precedentes do próprio processo de desenvolvimento do PSS que consideram as restrições operacionais e as práticas e métodos de controle direcionados à disponibilização e adição do valor. Portanto essas questões definem os "fatores operacionais e de controle" (8a) dos subsistemas de produção e prestação. Ainda como influências internas a perspectiva de análise admite a atuação das atividades de desenvolvimento como meio de intervenção e ajuste dos aspectos operacionais. Portanto, o sistema em análise também recebe influência de fatores internos ao longo do tempo por meio da intervenção na qualidade do (8b) bem tangível e também do (8c) serviço.

Como salientado até então, esta abordagem utiliza o conceito de valor pela conveniência à abordagem ao PSS. As abordagens específicas referentes ao tratamento do valor no contexto do PSS assumem diferentes perspectivas. A abordagem de Richter, Sadek e Steven (2010) utiliza esse conceito, focando no contexto interno do fabricante na relação dos benefícios da modularidade de um sistema em função dos custos e do risco do nível de flexibilidade requerido para tal. Já Rese, Karger e Strotmann, (2009) utilizam uma combinação de métodos para estabelecer uma perspectiva do valor oferecido por diferentes configurações do sistema, também considerando a flexibilidade exigida. Essas abordagens contribuem para o tratamento do valor nessa análise, contudo, a perspectiva de abordagem de interesse está no contexto dinâmico de interação do sistema. Portanto, o processo de construção do modelo desenvolvido no capítulo seguinte trabalha a consideração do valor sobre uma perspectiva dinâmica envolvendo os três subsistemas identificados como fundamentais para a análise. Como 
proposto, as interações entre os subsistemas ressaltadas nesse tópico orientam a construção da estrutura de fatores do modelo, assunto do capítulo seguinte.

\section{CONSTRUÇÃO DO MODELO}

Neste capítulo é desenvolvida a modelagem do contexto do PSS conforme fundamentado no capítulo anterior. Inicialmente o tópico "condução da modelagem" expõe as principais considerações que orientaram os processos de modelagem, os stakeholders e os subsistemas englobado na análise. A compreensão em termos sistêmicos é gerada pela descrição lógica do contexto. Nessa descrição os fatores de influência entre os subsistemas e suas interações são expandidos e explorados de maneira a evidenciar e associar os ciclos de realimentação que conferem as não linearidades do comportamento do sistema e resultando em um diagrama (ou modelo) conceitual. Esse diagrama é convertido para a linguagem de fluxos e estoques para o detalhamento dos fatores de influência no sistema em termos de unidades de mensuração, sua associação para a formação da estrutura responsável pelo comportamento dinâmico e para a inserção das equações referentes à integração matemática entre esses fatores.

\subsection{CONDUÇÃO DA MODELAGEM}

A estruturação do modelo se inicia já na definição dos stakeholders e subsistemas englobados na caracterização da análise. Assim, o comportamento no tempo é dado pela interação entre os subsistemas de produção, prestação e consumo, abordados na fundamentação de maneira a relacionar as principais influências na dinâmica desta interação. A Figura 16 ilustra a interação entre os stakeholders e, como tal, entre os subsistemas apontados. Essa ilustração estabelecida numa visão de processo permite apresentar o contexto a ser representado pela modelagem. Nesse contexto a atuação da atividade de desenvolvimento na correção da qualidade dos elementos também está representada na Figura 16. A modelagem também considera esse aspecto salientado na fundamentação específica.

Na etapa interpretativa de construção do diagrama de causalidade é conduzida considerando a atuação conjunta dos subsistemas de produção e prestação para a na criação e entrega do valor. $\mathrm{Na}$ perspectiva sistêmica adotada o fabricante atua para o controle do fornecimento de valor ao sistema, enquanto que o prestador atua para o controle da agregação de valor. O ingresso ao sistema é considerado pela solicitação de produtos e a posterior associação de serviços. O subsistema de 
prestação, portanto, é visto como um módulo de serviço possivelmente integrante de uma rede de extensão de valor associado ao produto.

Figura 16 - Estrutura de referência para a condução da modelagem

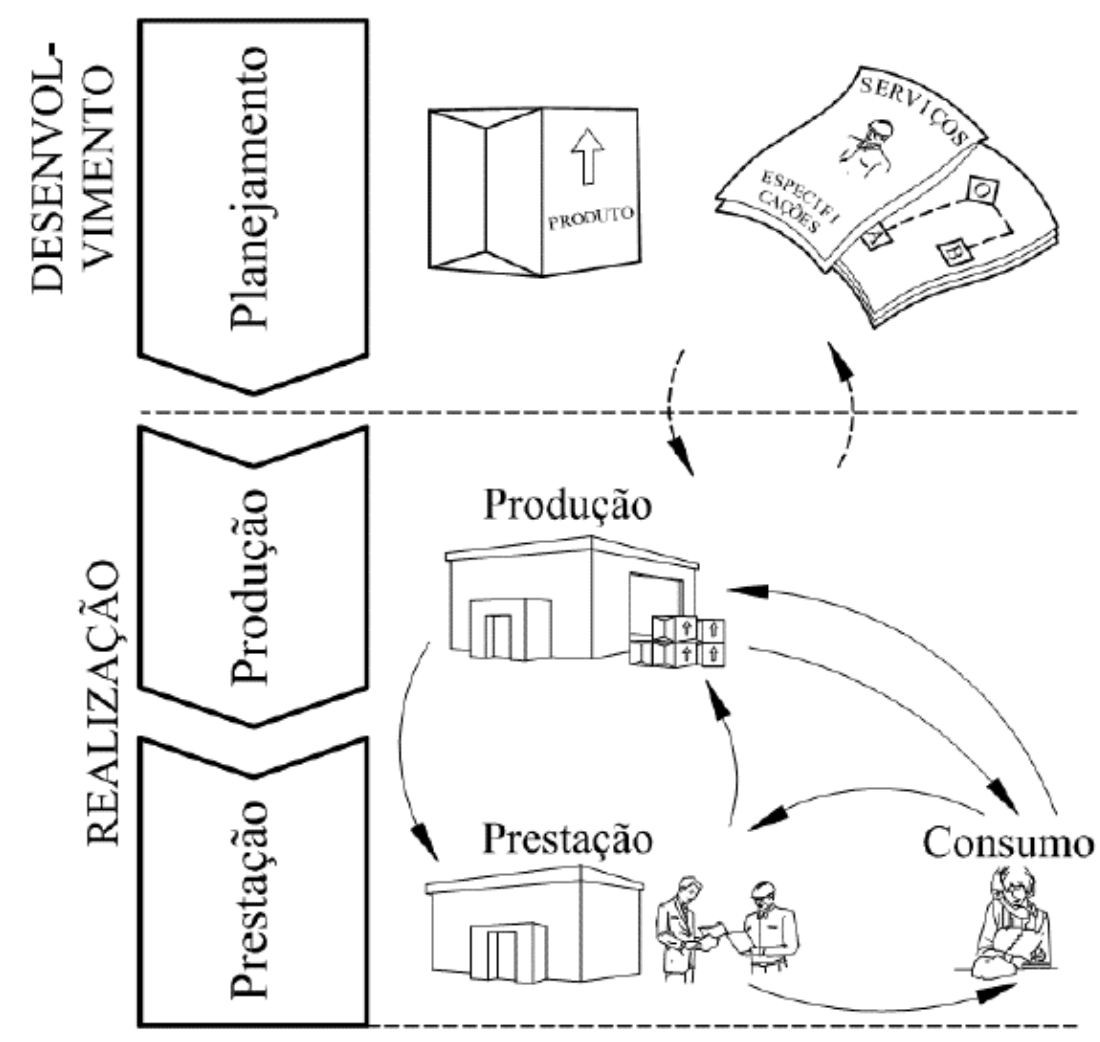

Fonte: o autor.

Para a construção deste diagrama a representação do subsistema de produção utiliza a estrutura genérica de gestão de estoques ${ }^{18}$. A proposição da estrutura para a representação da agregação de um módulo genérico de serviços (o subsistema de prestação) é feita por analogia ao subsistema de produção. O diagrama referente ao subsistema de consumo aborda as considerações acerca da percepção e tem base em modelagens dinâmicas já empregadas na bibliografia especializada. Dessa forma são definidas as constantes e variáveis do modelo para simulação.

Essas são as principais considerações que orientam os processos de modelagem. Com isso se estabelece as condições para a simulação fornecer os cenários para análise do comportamento dinâmico do sistema. Então, nas seções seguintes são descritas a operacionalização da atividade de construção do modelo iniciando pela modelagem conceitual. 


\subsection{MODELAGEM CONCEITUAL}

Os ciclos de realimentação são os elementos básicos empregados na modelagem conceitual de um sistema pelo uso do diagrama de causalidade. Esses ciclos são os responsáveis pela aplicação do paradigma da Dinâmica de Sistemas referente à informação/ação/consequência e, em função disto, são também os responsáveis pela característica de não linearidade do comportamento do sistema. De acordo com o objetivo os ciclos de realimentação integrantes do modelo representam os fluxos (físicos ou não) de interesse para a análise. Eles podem corresponder a um subsistema em específico, ou mesmo, atuar na interação entre os subsistemas.

Na descrição conceitual proposta para o contexto dois ciclos de realimentação principais inserem as atribuições do fabricante do bem tangível e do prestador de serviços na perspectiva de análise. 0 primeiro, denominado "controle da produção" apresenta o controle do subsistema de produção com a alocação dos recursos produtivos pela observação do nível de estoques ${ }^{19}$. Esse ciclo de realimentação negativo é descrito detalhadamente na seção seguinte. Já na seção subsequente é apresentado o segundo ciclo, denominado "controle da prestação". Assim como o ciclo anterior este também tem a alocação de seus recursos, nesse caso os recursos demandados para a prestação dos serviços, como uma função da demanda por esses serviços possibilitando o controle do subsistema de prestação.

\subsubsection{CICLO DE REALIMENTAÇÃO “CONTROLE DA PRODUÇÃO"}

Sendo o subsistema de produção o fornecedor do elemento tangível do valor do PSS, o ciclo de realimentação referente a este subsistema expõe a atuação sistêmica para o controle desse fornecimento. Insere, dessa forma, o stakeholder foco (o fabricante) no contexto fundamentado para o ciclo de vida no PSS. Esse controle depende do conhecimento do sistema (constituição e capacidade em termos físicos, humanos, tecnológicos, e seus mecanismos de controle como procedimentos e políticas), assim como o conhecimento da dinâmica de abastecimento do sistema pela rede de suprimentos. Portanto a abordagem conceitual ao subsistema de produção condiz com o gerenciamento destes recursos necessários à fabricação dos produtos.

O ciclo de "controle da produção" utiliza o termo "artefatos produzidos" generalizando o bem tangível de um PSS como o resultado do processo produtivo. Em situações práticas uma quantidade mesmo que mínima de estoque de artefatos produzidos pode ser observada e, em muitas situações (principalmente envolvendo produtos industrializados) são de tal monta que demandando custos 
significativos para sua manutenção. Um nível planejado de estoques de artefatos produzidos permite o atendimento ao sistema sem que ocorram falhas. Em vista disto a manutenção de um nível planejado de estoques de artefatos produzidos é adotada como o meio para que não haja falhas na "alimentação" das estruturas de entrega de valor no PSS. Isto acarreta que a correlação entre a demanda por produtos e a quantidade de trabalho em processo é realizada pelo controle de estoques de artefatos produzidos, ou seja, o objetivo do subsistema de produção consiste em atuar nos recursos para manter um determinado nível de estoques e, portanto, prover a "disponibilidade de valor" referente ao bem tangível. Essa dinâmica de controle é apresentada na Figura 17.

Figura 17 - Ciclo de realimentação "controle da produção"

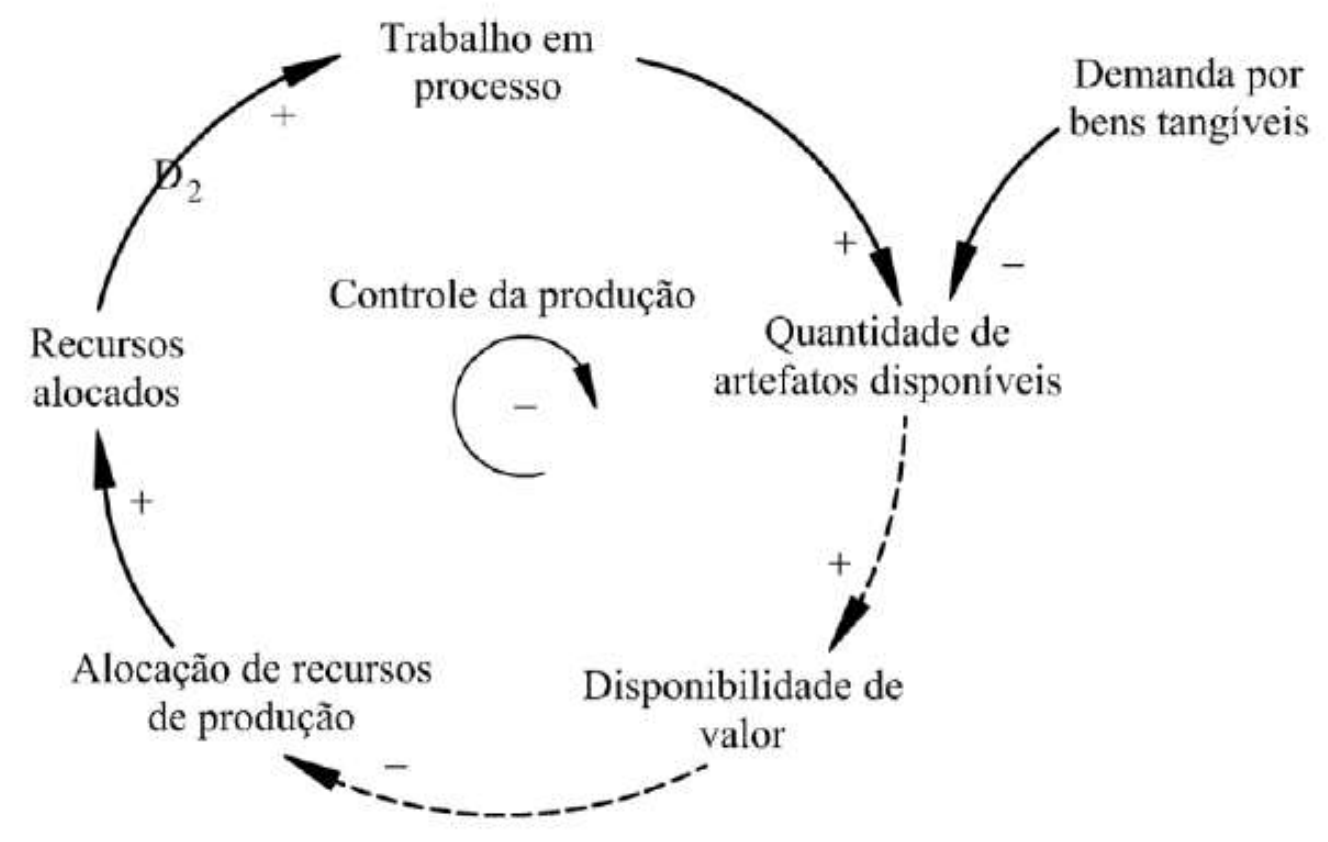

Fonte: o autor.

A interpretação sistêmica do ciclo de realimentação "controle da produção" pode ser feita considerando, inicialmente, uma redução da variável "quantidade de artefatos disponíveis" ocasionada por um aumento da demanda por bens tangíveis (relação inversa). No controle da produção a redução do estoque de artefatos disponíveis indica que o nível de produção precisa ser adequado à nova demanda. Essa relação estabelece que quanto maior a demanda por bens tangíveis, menor a quantidade de artefatos disponíveis e, portanto, menor a "disponibilidade de valor" referente ao bem tangível para a utilização do sistema. O controle da produção atua então na "alocação de recursos de produção", sendo quanto menor a disponibilidade de valor mais recursos são alocados ao sistema produtivo para prover sua própria readequação. A “alocação de recursos de produção" condiz 
com uma das tarefas dos gestores de readequarem os recursos de produção e pode refletir políticas e processos específicos do fabricante. A relação entre essas duas variáveis também é "positiva", ou seja, quanto maior a "alocação de recursos de produção" maiores as quantidades de "recursos alocados". Como consequência de mais "recursos alocados" o sistema apresentará um aumento no "trabalho em processo", sendo sistemicamente, quanto mais recursos alocados mais trabalho em processo no sistema produtivo. Por fim, fechando-se o ciclo de realimentação, a maior quantidade de trabalho em processo acarretará no aumento da "quantidade de artefatos disponíveis". Do instante de aumento do "trabalho em processo" até que a "quantidade de artefatos disponíveis" também aumente existe uma defasagem de tempo que é característica do sistema. O fluxo do "trabalho em processo" para a "quantidade de artefatos disponíveis" se caracterizada por um fluxo físico de bens nas etapas dos processos produtivos.

O ciclo de realimentação "controle da produção" consiste em um ciclo negativo. Assim como o sistema produtivo é representado conceitualmente neste ciclo, o sistema de prestação que complementa o controle da dinâmica representada é abordado no tópico seguinte. Como salientado na condução da modelagem o ciclo de realimentação "controle da prestação" é construído considerando o controle da agregação de valor com atuação conjunta no sistema.

\subsubsection{CICLO DE REALIMENTAÇÃO “CONTROLE DA PRESTAÇÃO”}

O controle da prestação insere a responsabilidade dos prestadores de serviços no contexto fundamentado para o PSS que consiste em prover o elemento intangível do valor. Para tal, em analogia ao subsistema de produção o subsistema de prestação também precisa controlar seus recursos humanos, tecnológicos, ou quaisquer outros recursos necessários. O ciclo de realimentação "controle da prestação", mostrado na Figura 18, expõe a atuação sistêmica para o controle do fornecimento de serviços que, ao contrário da produção de artefatos (na qual a disponibilização desses pode ser vista como um evento do sistema) a entrega de serviços se dá ao longo do tempo. Nesse sentido, o ciclo "controle da prestação" utiliza os termos "consumidores em processo" e "consumidores processados" porque, enquanto a produção transforma o trabalho em processo em artefatos produzidos, a prestação "transforma" os consumidores com uma expectativa de valor em consumidores satisfeitos. Ou seja, na prestação de serviços são "processados" consumidores. 
Figura 18 - Ciclo de realimentação "controle da prestação"

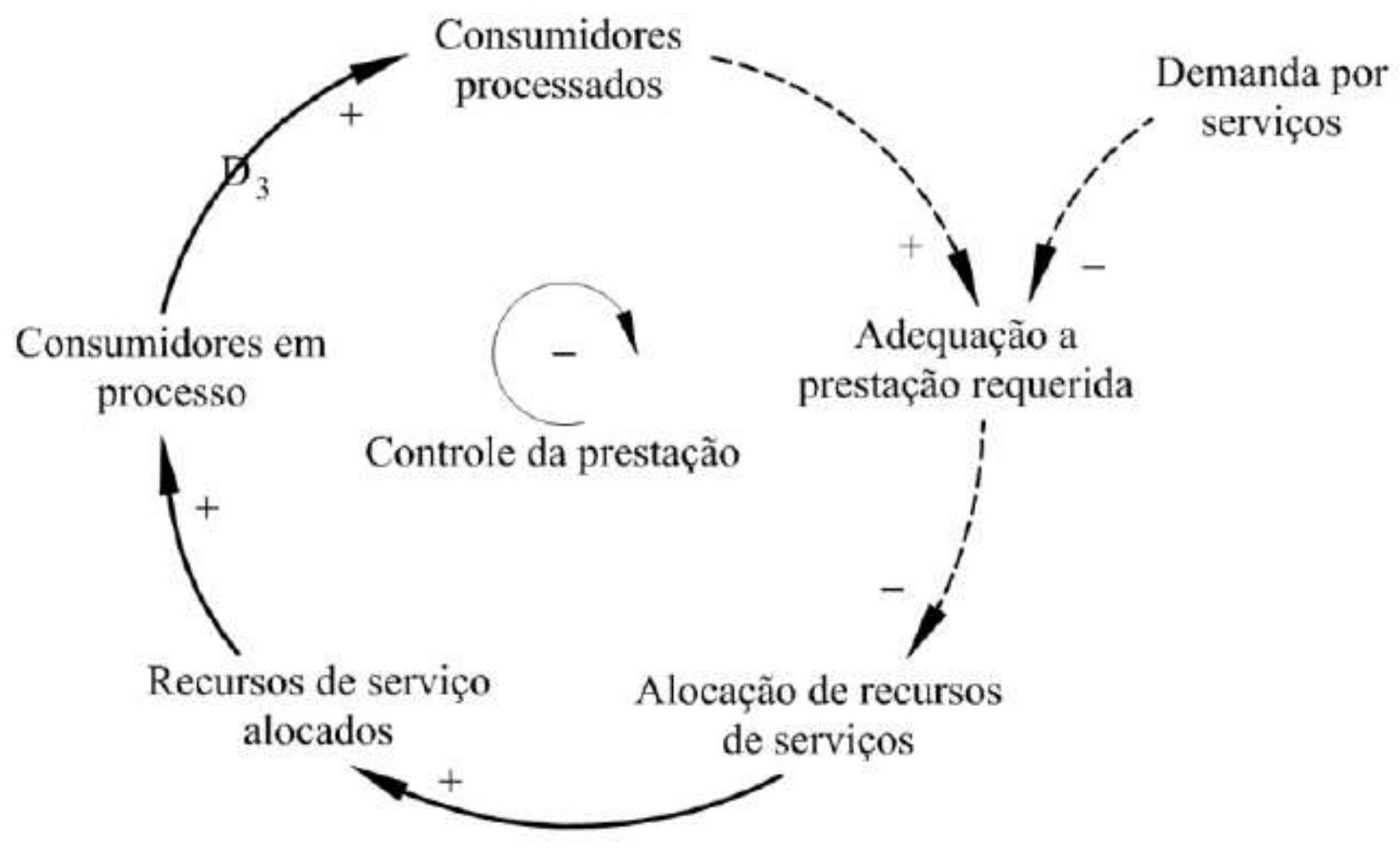

Fonte: o autor.

O ciclo de realimentação "controle da prestação", assim como a produção, também é um ciclo negativo. Mas nesse caso o controle não é dado em função do nível de estoque. Está condicionada à disponibilidade de valor, contudo é orientada pela demanda pelos serviços. Essa demanda provoca um afastamento do nível de prestação requerida ao nível atual (a "adequação da prestação requerida") e, quanto maior esse afastamento, maior a alocação de recursos de serviços. Com os recursos alocados são admitidos um maior número de consumidores em processo e, dado o tempo necessário para o processamento, um maior número de consumidores processados.

Este ciclo e o ciclo de controle da produção são apresentados novamente no diagrama de causalidade explorado na sequência. Este diagrama estabelece a associação entre esses ciclos e insere os demais ciclos na formalização do contexto.

\subsubsection{DESCRIÇÃO CONCEITUAL}

A descrição conceitual do sistema é formalizada pelo diagrama de causalidade. Esse diagrama explicita o contexto em que o PSS ocorre, conforme essa abordagem, organizando e apresentando as informações da fundamentação teórica em uma visão dinâmica de atuação. Além disto, o diagrama 
de causalidade também insere as teorias dinâmicas para a determinação da estrutura do sistema. Ou seja, esse diagrama associa os fatores de forma a representar a relação que caracterizam o modelo.

No contexto descrito pelo diagrama de causalidade, representado por completo na Figura 19, a atuação do subsistema de produção é conduzida pela "demanda de referência". Essa demanda é um dos fatores exógenos ao sistema. Sua aplicação ao nível de "artefatos disponíveis" do subsistema de produção define o ingresso ao PSS. Portanto, esse ingresso ocorre pela solicitação dos bens tangíveis desencadeada pelo consumidor. $\mathrm{O}$ atendimento da demanda de referência pelo sistema produtivo gera uma demanda futura pelos serviços associados. Essa demanda futura é denominada de "demanda por serviços". Em termos de enlaces causais essa dinâmica é representada por uma defasagem de tempo (D1) à "demanda por serviços".

De acordo com o fundamentado e estabelecendo a conformidade com essa etapa da análise o "pacote de valor" é entendido como "o conjunto de atributos disponibilizados pelo bem tangível, pelo módulo de serviço associado a ele e pela sua interação responsáveis pelos benefícios entregues ao consumidor". Na descrição do sistema, vista a perspectiva e as considerações da análise, a atuação mútua e sistêmica dos ciclos de realimentação de controle dos subsistemas de produção e de prestação tem como objetivo a criação e entrega do pacote de valor proposto pelo sistema ${ }^{20}$. Assim, a ação desses ciclos está associada aos fatores "facilidade de obtenção do valor" e "facilidade de consumo do valor". O emprego destes termos atribui, em uma linguagem conveniente, os reflexos das ações de controle dos aspectos de produção e prestação para o objetivo do sistema. Os ciclos de realimentação dos subsistemas de produção e prestação (apresentados isoladamente nas seções anteriores) são representados de forma simplificada no diagrama de causalidade.

A associação da dinâmica do sistema com o subsistema de consumo na descrição conceitual proposta é estabelecida pela "percepção do valor". Para tanto essa percepção é segmentada para os elementos de (i) bem tangível e (ii) serviço, componentes do sistema.

Associando essa descrição à fundamentação teórica específica referente à interação entre esses elementos, mesmo em sistemas orientados ao resultado em que o produto viabiliza um resultado acordado o bem tangível apresenta aspectos e atributos que influenciam no julgamento do consumidor quanto à sua excelência frente aos seus objetivos e necessidades (a qualidade percebida referente ao artefato físico). Quando esses aspectos e atributos igualam ou excedem as expectativas iniciais (a "expectativa de qualidade do bem tangível") construídas com base em seus valores e preferências pessoais frente à comparação com as ofertas similares ou concorrentes no mercado tem- 
se a condução para uma condição de "valor satisfeito (bem tangível)". Ou seja, o valor satisfeito é a condição para a solicitação de bens ao sistema produtivo e, como tal, para o ingresso no sistema. Essa dinâmica também está descrita sistemicamente na Figura 19 associada ao ciclo de realimentação denominado "controle da qualidade do bem tangível" e com influência direta na "demanda de referência". Na relação descrita o aumento da "qualidade percebida (bem tangível)" diminui a "diferença entre a expectativa de qualidade e a qualidade percebida". A redução dessa diferença, portanto, conduz o consumidor à condição de "valor satisfeito" ${ }^{21}$. Esse ciclo (assim como o seu equivalente para os serviços) insere no contexto a atuação da atividade de desenvolvimento como o meio de influência na percepção do consumidor e na operacionalização do sistema.

Ainda na associação dos subsistemas de produção e prestação é admitido que os consumidores, dado o tempo para a adição de valor pelos serviços, aderem ao módulo de prestação por uma "taxa de adesão". Nesse sentido, da mesma forma que para os bens tangíveis a taxa de adesão é influenciada pelos aspectos das dimensões da qualidade dos serviços conforme a percepção do consumidor que conduzem a "qualidade percebida (serviços)" para a condição de "valor satisfeito (serviços)". Ou seja, em analogia aos bens tangíveis, a taxa de adesão tem relação com os aspectos e atributos que influenciam no julgamento do consumidor quanto à sua excelência dos serviços frente aos seus objetivos e necessidades (a qualidade percebida referente aos serviços). Nesse sentido a descrição conceitual segue o considerado para o subsistema de produção. Como pode ser visto na Figura 19, quando a percepção dos aspectos da qualidade referente aos serviços que influenciam as expectativas iniciais referentes a tais serviços iguala ou excede essas expectativas iniciais (construídas com base em seus valores e preferências pessoais frente à comparação com as ofertas similares ou concorrentes no mercado) tem-se a condição de "valor satisfeito (serviço)". Bem como na consideração do subsistema de produção a possibilidade de atuação da etapa de desenvolvimento na qualidade percebida referente aos serviços também é expressa nas relações causais compondo o ciclo de realimentação "controle da qualidade dos serviços". A estrutura sistêmica deste ciclo é idêntica ao ciclo de controle da qualidade dos bens tangíveis tendo como diferença a extensão da defasagem de tempo entre a intervenção no artefato ou no serviço e a qualidade percebida relativa a esses elementos. Portanto, na sequência é apresentada a Figura 19 que explicita o diagrama de causalidade por completo expondo e associando os ciclos de realimentação. 
Figura 19 - Diagrama de causalidade (descrição do contexto)

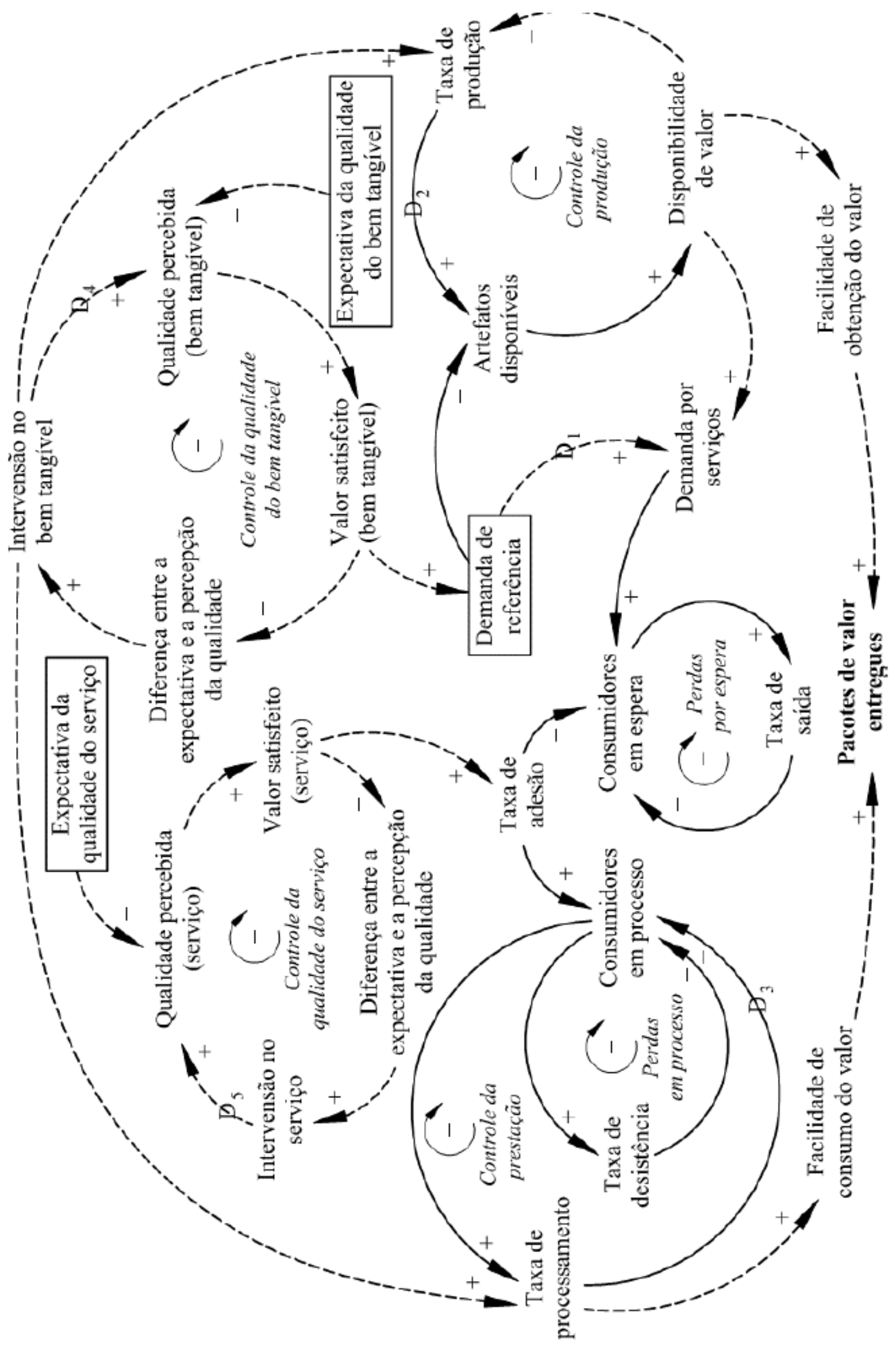

Fonte: o autor. 
As considerações que orientaram a descrição do contexto tem coerência com as características e funções básicas dos serviços técnicos apontados por Aurich, Fuchs e Wagenknecht (2006). Essas características apontam que (i) os serviços técnicos são essencialmente não físicos, (ii) são consumidos à medida que são produzidos (não podendo ser armazenados, e (iii) sua realização requer a integração com o produto. A intangibilidade como característica dos serviços abordados é considerada ainda na fundamentação da análise e ficará evidente na modelagem de fluxos e estoque (já que o fluxo não consiste em materiais físicos) abordada adiante. Já a produção e o consumo simultâneo dos serviços técnicos é representada no contexto uma vez que no ciclo "controle da prestação" o fluxo consiste em consumidores sendo processados (consumidores em processo) por uma "taxa de processamento". Mas ainda no contexto o fator "intervenção no bem tangível" além de influenciar na qualidade percebida, como já descrito, também tem observada sua associação com a "taxa de produção" e com a taxa de prestação (descrita pelo fator "taxa de processamento"). Essa consideração converge com a integração requerida aos serviços técnicos (AURICH; FUCHS; WAGENKNECHT, 2006; ABRAMOVICl; BELLALOUNA; GÖBEL, 2010). Dessa maneira o contexto contempla que a intervenção no bem tangível pode conduzir também a uma maior facilidade de obtenção e de consumo do valor. Nesse sentido se considera que os benefícios referentes ao serviço ocorrem junto ao artefato físico (e, como tal, estabelecendo interação com este) de maneira a maximizar seu desempenho ou complementar a funcionalidade na agregação de valor.

Nessa descrição também são expostos os ciclos de realimentação que representam as possibilidades de falhas ao sistema ${ }^{22}$ em duas situações. Visto que os consumidores passam a ser efetivamente processados a partir da "taxa de adesão" admite-se a possibilidade de formação de um acúmulo de consumidores em espera. Nesse sentido a "taxa de saída" insere as perdas do sistema em caso de geração de consumidores em espera. Essa perda poderia estar vinculada, por exemplo, ao não atendimento dos prazos contratados, fator salientado por Phumbua e Tjahjono (2011). Sistemicamente quanto mais consumidores em espera, maior a taxa de saída que, fechando o ciclo, reduz o fator inicial de consumidores em espera. Dessa forma esse também é um ciclo negativo de controle do sistema (denominado na Figura 19 de "perdas por espera"). Da mesma maneira essa consideração é inserida para os consumidores em processo. Esses são reduzidos pela atuação da taxa de desistência. No diagrama causal essa falha é representada sistemicamente pelo ciclo de realimentação negativo "perdas em processo". 
Mas além dos fatores e suas associações os ciclos de realimentação detalhados e o diagrama de causalidade por completo também explicitam as indicações de defasagens de tempo (D1 a D5). Essas defasagens correspondentes ao tempo decorrido do início de uma ação e até seu reflexo no sistema. Cada uma destas é definida na sequência.

\subsubsection{DEFASAGENS DO SISTEMA}

Além das interações entre os fatores do sistema as figuras que representam as relações de causalidade também indicam as defasagens 23 consideradas relevantes na dinâmica abordada. Essas defasagens são identificadas na Figura 19 como D1, D2, D3, e D4 e correspondem à:

- D1 - Essa defasagem corresponde ao tempo decorrido da aquisição do bem tangível até a agregação dos serviços associados. Esse tempo é um fator que pode apresentar muita variação. Para alguns sistemas o serviço associado pode se dar em um tempo relativamente curto após a aquisição como, por exemplo, serviços de entrega ou treinamento. Enquanto para outros esse tempo pode ser maior como serviços técnicos de manutenção programada.

- D2 - Corresponde ao tempo decorrido da alocação do "trabalho em processo" até a obtenção dos "artefatos disponíveis". Ou seja, corresponde ao tempo demandado pelas atividades produtivas para a fabricação dos bens tangíveis.

- D3 - Refere-se ao tempo necessário para o processamento de um consumidor. Corresponde, então, ao tempo demandado para a realização das atividades de serviços planejadas para a obtenção do valor entregue pelo sistema.

- D4 - Essa defasagem representada no sistema se refere ao tempo necessário para que a qualidade percebida pelo consumidor em relação ao produto seja ajustada ao nível corrigido.

- D5 - Analogamente ao sistema produtivo, este atraso corresponde ao tempo necessário para que a correção da qualidade efetuada nos aspectos e características de serviço seja percebida pelo consumidor.

Além destas outras defasagens poderiam ser apontados como o tempo necessário para a alocação de recursos produtivos ou de serviços. No entanto, essas são as defasagens consideradas mais significantes para esta análise e voltarão a ser abordadas, logo na sequência, de maneira aplicada ao modelamento por fluxos e estoques e equações do modelo.

\subsection{MODELAGEM ESTRUTURAL}

A estrutura do modelo é construída aplicando o diagrama de fluxos e estoques, pois este relaciona as diversas constantes e variáveis englobadas pela análise. A construção desse diagrama é orientada pelo próprio diagrama de causalidade de forma a manter os conceitos representados neste último. 0 modelo de fluxos e estoques possibilita a implementação matemática além de definir os principais indicadores que representam o estado do sistema. 
O diagrama de fluxos e estoques completo do sistema em análise nesta análise pode ser dividido em três partes correspondentes aos subsistemas de produção, prestação, o consumo. Cada uma destas partes apresenta seus estoques e taxas de fluxos nomeadas de forma a melhor definir sua representação para o modelo. Da mesma maneira as constantes e variáveis são nomeadas buscando o melhor entendimento de sua função no sistema.

\subsubsection{FLUXOS E ESTOQUES NO SUBSISTEMA DE PRODUÇÃO}

No modelo proposto o diagrama de fluxo e estoque que representa o subsistema de produção tem base na estrutura estabelecida para o sistema de gestão de estoques (STERMAN, 2000), utilizado em estudos que abordam o sistema produtivo24. Nessa estrutura a produção é representada como um conjunto de processos transformando sucessivamente entradas em saídas. Representa, portanto, um fluxo de material pelo processo que se apresenta em diferentes condições e que geram estoques correspondentes aos estoques de materiais aguardando as atividades posteriores do sistema produtivo. Assim, apesar de que o objetivo do subsistema de produção no modelo proposto seja manter um determinado nível de "artefatos disponíveis" aguardando a expedição, os estoques podem se constituir de perfis metálicos adquiridos e aguardando a manufatura, ou componentes comerciais aguardando a montagem.

Nesse sentido a estrutura genérica de gestão de estoques pela linguagem da Dinâmica de Sistemas representa o contexto interno do fabricante por um fluxo de materiais (unidades de materiais) submetido a dois estoques intermediários que correspondem, então, à quantidade de materiais em dois estados: o de "trabalho em processo" e o de "artefatos disponíveis". O trabalho em processo consiste na quantidade de trabalho alocado a todas as atividades produtivas que se fazem necessárias para a fabricação do bem tangível. Esse trabalho em processo tem como "entrada" os insumos adquiridos da cadeia de suprimentos (insumos tangíveis ou intangíveis necessários para a fabricação do artefato). Assim, as diferentes atividades que dentro da abrangência do PSS e, consequentemente, das diversas configurações que o produto pode assumir, são específicas a cada fabricante sendo generalizadas em uma única etapa produtiva como uma etapa genérica do ciclo de vida no contexto do PSS. Fundamentalmente para a reprodução do comportamento de referência para o sistema, o "trabalho em processo" insere a defasagem temporal existente entre a operação de solicitação (emissão de ordens de produção) para abastecer o estoque de "artefatos disponíveis" (que corresponde ao estado final em que o material se apresenta na estrutura) e a ocorrência desse evento. Esses estoques são influenciados pelas taxas e fatores de influência que constituem a estrutura de 
decisão que governa os níveis de estoques. Nessa estrutura o estoque de "trabalho em processo" é controlado pela "taxa de início de produção" e pela "taxa de conclusão da produção", e o estoque de "artefatos disponíveis", influenciado pela mesma "taxa de conclusão da produção" e pela "taxa de entrega". A Figura 20 representa este fluxo e seus estoques, as taxas que regulam os estoques e os fatores de influência que descrevem esse subsistema.

Figura 20 - Diagrama de fluxo e estoque do subsistema de produção

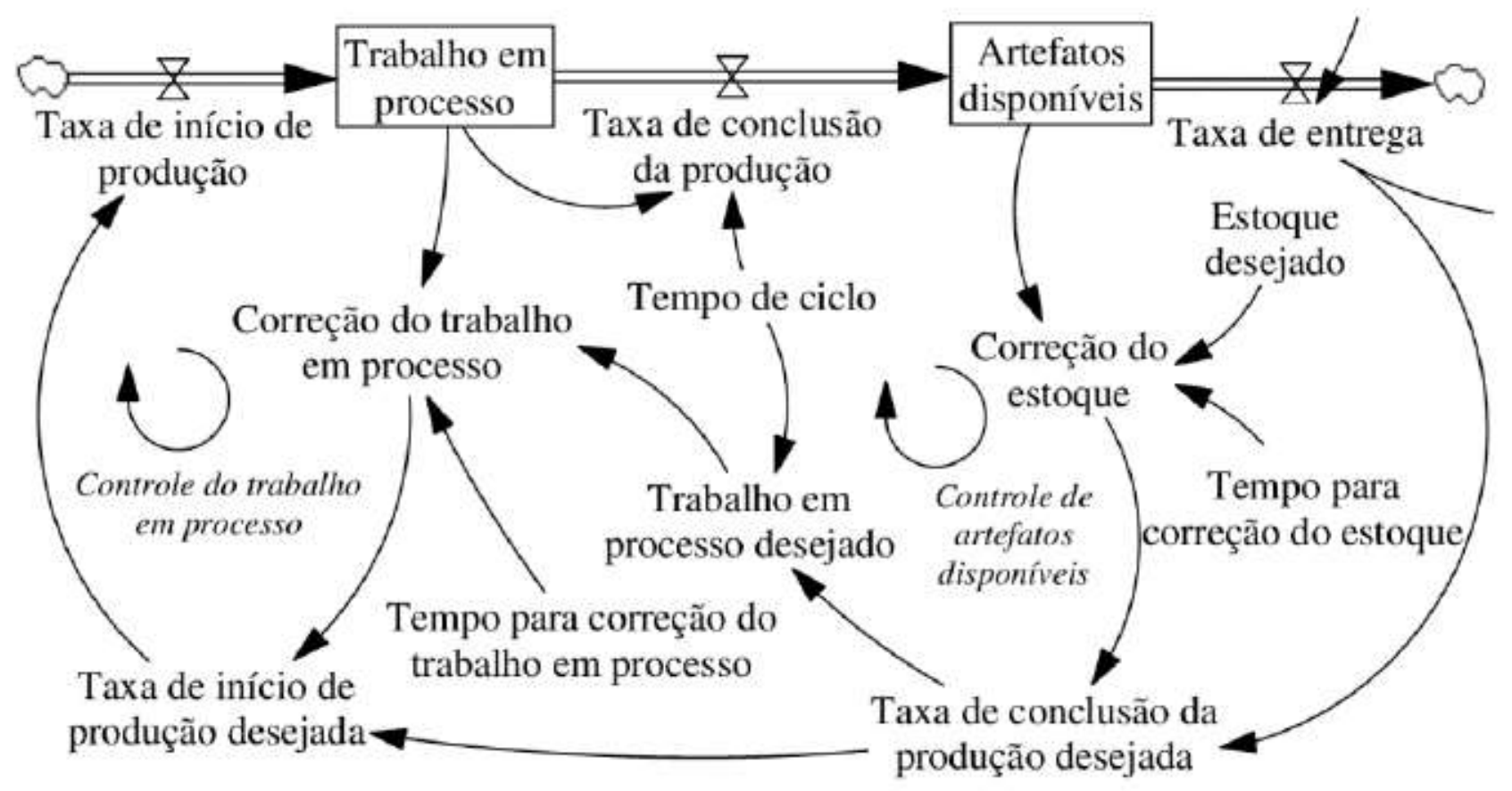

Fonte: adaptado de Sterman (2000).

Assim, no modelo o nível do estoque "trabalho em processo" influencia diretamente a "taxa de conclusão da produção" que controla o nível deste estoque, correspondendo a um ciclo de realimentação negativo. Essa influência confere ao modelo a não linearidade uma vez que relacionam os estoques com as taxas que os controlam. Juntamente, uma estrutura do sistema conduz o reflexo da alteração do nível do estoque "trabalho em processo" para a "taxa de início de produção" que controla o aumento do nível deste estoque, descrevendo um ciclo negativo e refletindo a busca do controle pelo sistema com a correção pelo trabalho em processo, dessa forma, denominado "controle do trabalho em processo". Também o nível do estoque de "artefatos disponíveis" pela estrutura do sistema denominada "controle de artefatos disponíveis" reflete a busca pelo controle do sistema com a "correção do estoque" que acaba por influenciar a "taxa de início de produção", constituindo outro ciclo de realimentação negativo. 


\subsubsection{FLUXOS E ESTOQUES NO SUBSISTEMA DE PRESTAÇÃO}

Com a associação do modelo que representa o sistema de produção ao sistema de prestação as fronteiras do sistema do fabricante são estendidas aos responsáveis pela prestação de serviços. A construção do modelo de fluxos e estoques para o sistema de prestação de serviços proposto nesta análise é feita com analogia ao processamento de produtos, assim como é salientado na condução da modelagem. O fluxo que se apresenta no sistema não consiste de material para transformação, mas sim de consumidores submetidos às atividades de serviços. Esse fluxo é representado em três estados diferentes, tendo então três estoques como mostrado na Figura 21. O primeiro estoque, "consumidores em espera" é gerado pela "demanda por serviços" e representa uma população que pode adotar o PSS, que conforme a descrição conceitual se dá pela "taxa de adesão". Assim como para o subsistema de produção, em que as etapas de fabricação são representadas por uma única etapa do ciclo de vida (a etapa de produção) concentrando o trabalho em processo, a representação do subsistema de prestação adota a mesma consideração. Um único estoque também generaliza as diferentes atividades referentes ao módulo de serviços, concentrando os "consumidores em processo". A entrega de valor pelas atividades de serviço ocorre por uma "taxa de processamento". Essa última diminui o nível do estoque de consumidores em processo e alimenta o último indicador do estado do sistema, o estoque de "consumidores processados" que, nessa análise mensura a quantidade de pacotes de valores entregues pelo sistema.

Esse modelo também considera a "taxa de saída" e a "taxa de desistência" para contemplar as possibilidades acerca do comportamento humano. Taxas de falhas não foram consideradas para o subsistema de produção, abordado de forma simplificada, para favorecer o contexto do PSS e também porque um componente em processo poderia ficar em espera um tempo indeterminado, o que não aconteceria com um consumidor. O sistema proposto contempla, para cada estoque, as entradas e saídas separadamente por poderem acarretar processos decisórios específicos. Essas "taxas de falha", como representadas na Figura 21, são influenciadas diretamente pelo nível do estoque ao qual estão associadas e por uma constante de tempo sendo inseridas para a análise dos aspectos de desempenho do sistema frente as possibilidade de falhas. As constantes são consideradas fatores exógenos ao sistema não sendo exploradas as relações específicas que influenciam no "tempo médio de saída" e no "tempo máximo em processo". 
Figura 21 - Diagrama de fluxo e estoque do subsistema de prestação

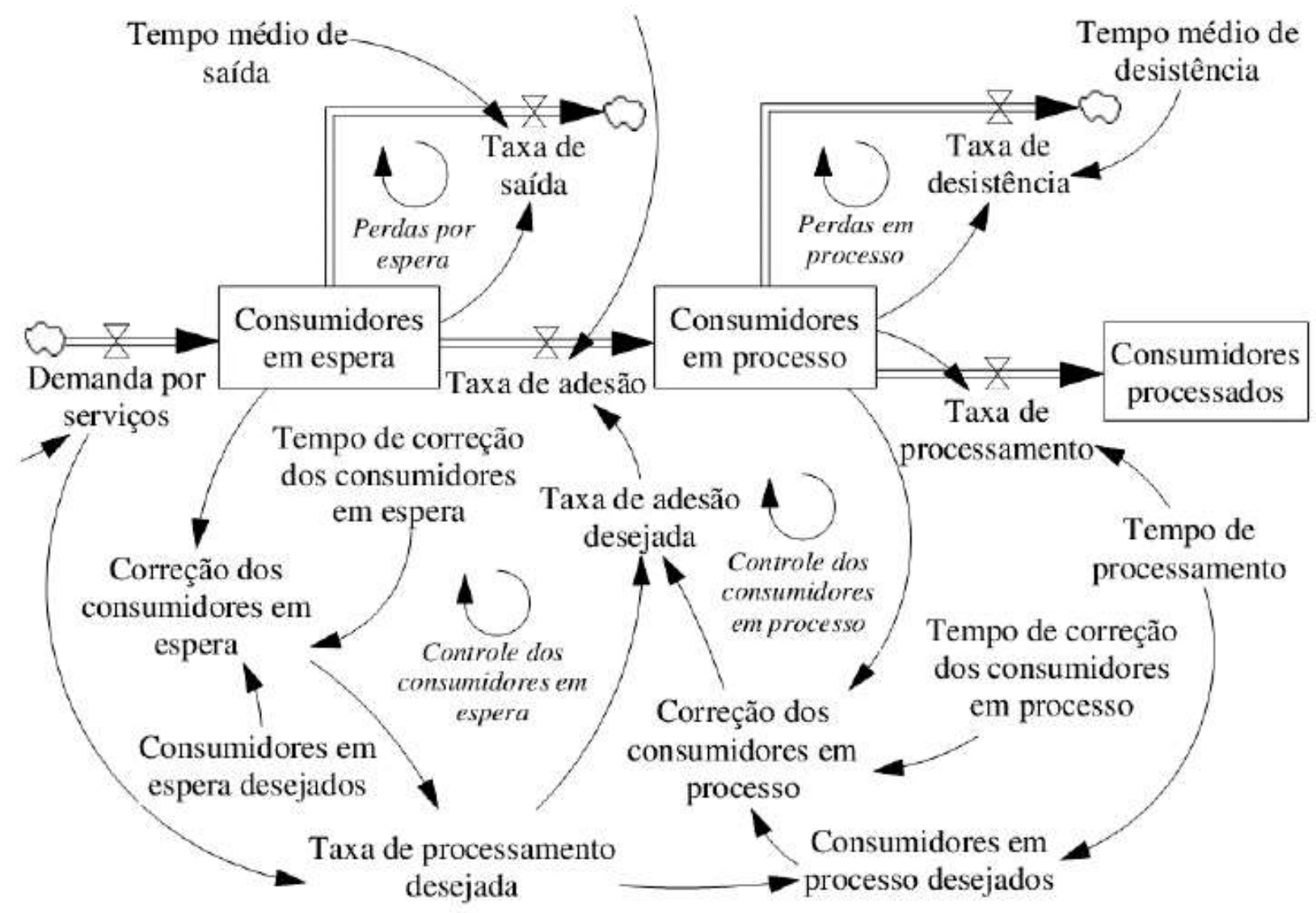

Fonte: o autor.

A estrutura de decisão para o subsistema de prestação também é análoga ao sistema produtivo constituído por dois ciclos de realimentação principais (o "controle dos consumidores em espera" e o "controle dos consumidores em processo"). O objetivo do controle do subsistema de prestação consiste em ajustar tal prestação à demanda por serviços buscando manter o nível do estoque "consumidores em espera" sem acúmulo. Havendo consumidores em espera o sistema precisa além de absorver a demanda por serviços também compensar a quantidade de consumidores em espera existentes. Na estrutura decisória proposta as taxas de adesão e de processamento controlam o sistema para a busca do equilíbrio da saída com a entrada. São inseridas as constantes que configuram operacionalmente o subsistema de produção para a dinâmica de interesse. Destas, o "tempo de processamento" corresponde ao tempo médio necessário para a realização das atividades de serviço. O "tempo de correção dos consumidores em processo" tem relação com as demandas técnicas e administrativas da gestão das atividades de prestação para ajuste do sistema para um novo montante. Já o "tempo de correção dos consumidores em espera" corresponde ao tempo médio necessário para realizar a adesão de novos consumidores no sistema. Essa estrutura explicita de maneira detalhada 
como o subsistema de prestação é considerado para esta análise. Contudo, processos decisórios diferentes para o controle do desse subsistema podem ser explorados.

\subsubsection{FLUXOS E ESTOQUES NO SUBSISTEMA DE CONSUMO}

Esta parte do modelo de fluxo e estoque é inserida pela consideração da entrega de valor pelo PSS estar condicionada a percepção do consumidor. Conforme o descrito conceitualmente a percepção do consumidor referente à qualidade se deve tanto ao elemento bem tangível quanto aos aspectos e características do elemento serviço. Apesar da característica subjetiva da percepção da qualidade essa é considerada e inserida em diagramas de fluxo e estoque por uma quantia acumulável no tempo ajustada por um ciclo de realimentação de primeira ordem25. Nesse sentido o fluxo presente no diagrama de fluxo e estoques do subsistema de consumo consiste em "percepção da qualidade" que alimenta um único estoque (sendo um para a percepção da qualidade do bem tangível e outro para os serviços). Então, o nível desse estoque representa o nível de qualidade percebida pelo grupo de interesse específico do PSS. O ajuste nesse nível insere a defasagem da percepção do consumidor entre a correção da qualidade aplicada tanto ao bem tangível quanto aos aspectos de serviço até a percepção desse novo estado da qualidade. Então o diagrama de fluxo e estoque do subsistema de prestação é dividido no ciclo de "controle da qualidade do bem tangível" e os fatores de influência deste (mostrado na Figura 22) e o ciclo de "controle da qualidade do serviço" também com seus fatores (mostrado na Figura 23).

Figura 22 - Diagrama de fluxo e estoque referente à qualidade percebida (bem tangível)

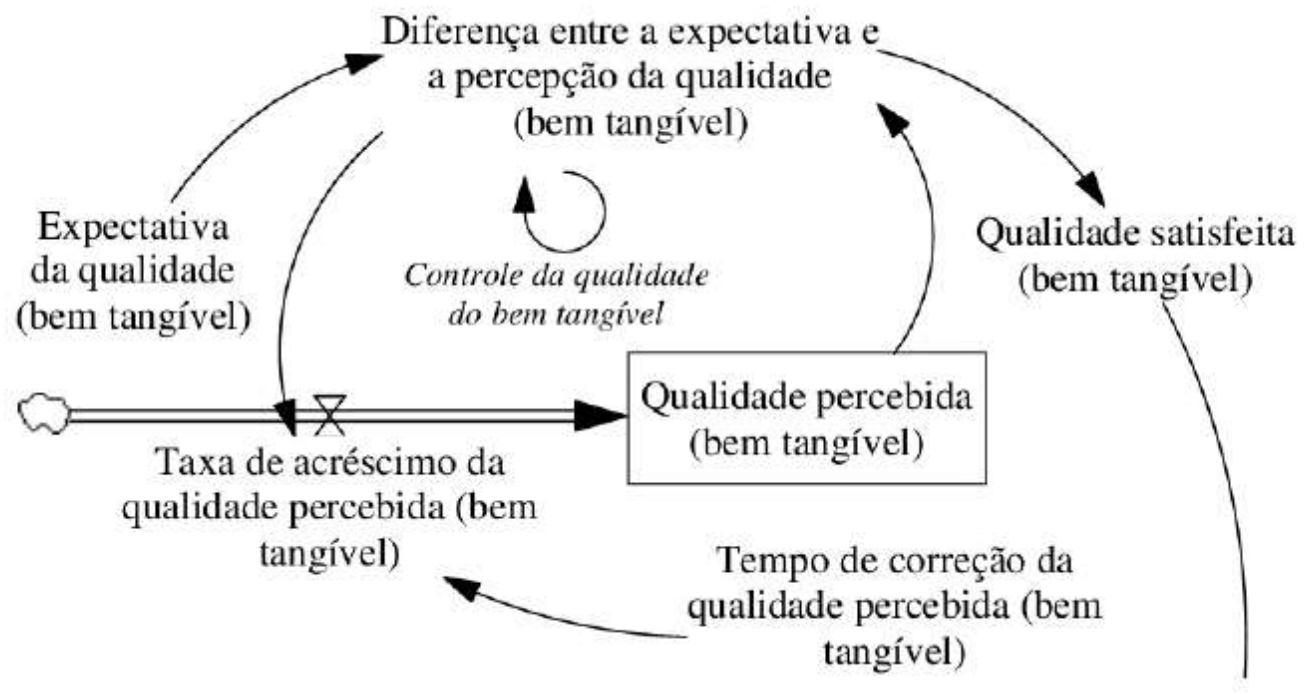

Fonte: adaptado de Kazemi, Eshlaghy e Tavasoli (2011). 
Figura 23 - Diagrama de fluxo e estoque referente à qualidade percebida (serviços)

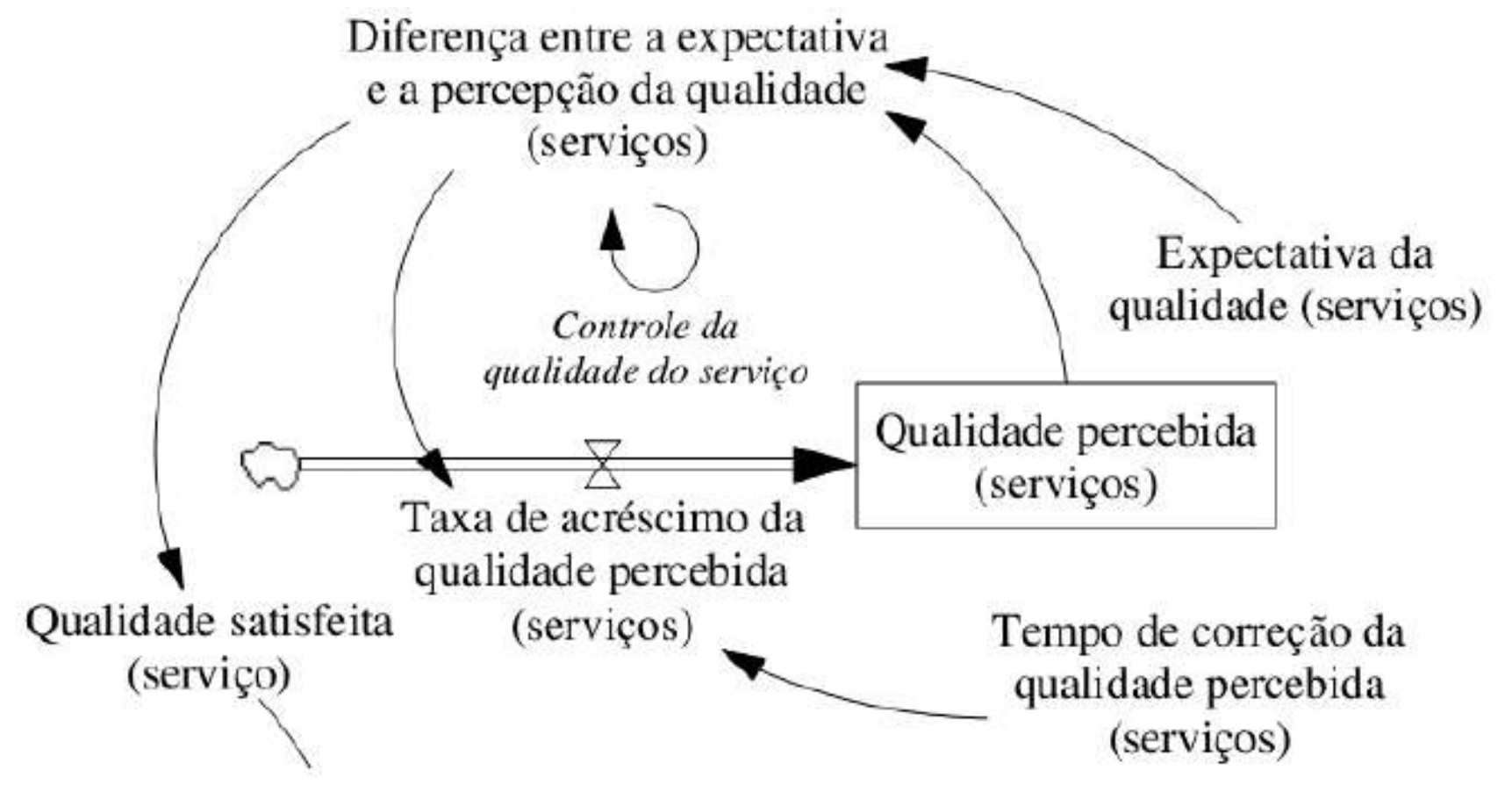

Fonte: adaptado de Kazemi, Eshlaghy e Tavasoli (2011).

Como pode ser visto a estrutura desses diagramas é idêntica, o que confere o mesmo comportamento dinâmico da qualidade percebida relativa aos elementos abordados. Porém, os valores (em cada instante) dos fatores específicos que compõem as estruturas determina o estado de cada estoque. Isto e sua ligação com o sistema determinam o seu efeito no comportamento.

Assim a aceitação do valor pelo consumidor resulta da consideração da influência estabelecida no sistema por essa percepção de qualidade. Essas influências, por sua vez, são relativas ao horizonte de tempo considerado. Para um horizonte contemplando toda a extensão do ciclo de vida (na perspectiva de sua introdução, crescimento, maturidade e declínio) a atuação no comportamento do sistema (que reflete o relacionamento da empresa com seus clientes) de fatores influenciados pela percepção de qualidade, como por exemplo, a "confiança do consumidor" e por consequência sua "lealdade" podem ser significativas. Nesse sentido exposto o "valor do cliente" considera toda a vida útil de consumo. Nesta abordagem, contudo, o horizonte de análise considera os reflexos mais imediatos da percepção do consumidor. Conforme o exposto na modelagem conceitual e consequentes considerações do modelo essas influências se refletem na taxa de desistência.

Com essas estruturas referentes ao subsistema de consumo a construção do modelo (estrutural) é encerrada. O modelo em sua íntegra, explicitando todas as relações entre os subsistemas, é apresentado no Apêndice A. Mas, essas relações ainda precisam ser definidas matematicamente. 


\subsection{MODELAGEM MATEMÁTICA}

Junto da construção da estrutura do diagrama de fluxo e estoques (que como ferramenta da DS facilita o modelamento matemático) as equações que definem as interações entre as constantes e variáveis complementam o modelo e viabilizam a implementação computacional. Uma explanação detalhada de todas as equações referentes a esse modelo (sendo discutida em relação aos subsistemas de produção, prestação ou consumo as quais pertencem) vinculando a linguagem matemática à estrutura do modelo (apresentando as equações de forma a ressaltar os fatores de influência diretos para cada variável) está apresentada em Ariente Neto (2013). Esse complemento expõe como as considerações feitas ao modelo até então se refletem na modelagem além das próprias considerações necessárias para a correlação matemática. $O$ foco da apresentação das equações, então, recai na analogia entre a linguagem do modelamento matemático e a função e implicações no sistema contextualizado.

Porém, no Apêndice B são pautadas as variáveis do modelo com suas respectivas equações (integral e a equivalente diferencial correspondente à taxa líquida de mudança do estoque no tempo) e unidades de mensuração. De forma geral, o termo "TO" corresponde ao período de tempo inicial da análise de interesse, enquanto o termo " $T$ " corresponde ao período final. O termo subscrito " 0 " é utilizado para designar o estado inicial da variável, enquanto o termo subscrito " $\mathrm{t}$ " descrimina as variáveis nos instantes específicos de interesse.

Em conjunto o Apêndice $C$ segmenta as constantes do modelo também expondo suas respectivas unidades. Ambos os apêndices podem ser utilizados como aporte a análise e entendimento do modelo.

\subsection{VALIDAÇÃO DO MODELO}

Apesar do modelo para simulação já estar construído, ainda demandando os testes previstos pela Dinâmica de Sistemas para a certificação que o modelo não apresenta erros, sendo considerado válido para a análise.

Os testes aplicados aos modelos da Dinâmica de Sistemas, como um processo em que se estabelece confiança no modelo, estão divididos em (i) teste de verificação de estrutura, (ii) teste de verificação de parâmetros e (iii) testes de comportamento. Os testes de reprodução de comportamento, por suas vezes, estão divididos em teste de reprodução do comportamento, teste de condições extremas, teste de robustez, teste de erro em regime estacionário e erro em regime permanente. Esses testes, e a devida discussão a respeito dos comportamentos simulados estão expostos em Ariente Neto (2013). 


\section{PROJEÇÃO DE CENÁRIOS E ANÁLISE}

Nesse capítulo são expostos os resultados obtidos pela simulação computacional. Inicialmente, no entanto, é descrito um caso de referência para interpretação desta etapa da análise correlacionada a uma situação prática do mercado. O processo de simulação da sequência ao capítulo culmina em um conjunto de informações gráficas, os cenários. Esse conjunto é segmentado em função das condições estabelecidas para a simulação permitindo a análise do comportamento do sistema. Essa análise e também as diretrizes e recomendações resultantes encerram, portanto, o exposto neste capítulo.

\subsection{CASO DE REFERÊNCIA}

Este tópico apresenta um caso referenciado pela literatura especializada que pode ser tomado como referência por enquadrar-se nessa perspectiva de análise. Esse caso é brevemente explanado salientando a correspondência com essa abordagem. O objetivo da consideração de um caso consiste em prover suporte a melhor compreensão e possibilitar analogias para a interpretação da análise. Para tal é tomado como referência o caso envolvendo o fabricante Caterpillar (LOVELOCK; WIRTZ; HEMZO, 2011) por englobar um produto industrializado em um segmento mecânico.

A Caterpillar é fabricante de equipamentos pesados de terraplanagem e construção. Para complemento de seu negócio fabril este fabricante desenvolveu um portfólio de serviços que configura diferentes módulos (termo empregado até então nesta abordagem). Conforme Lovelock, Wirtz e Hemzo (2011) esses módulos consistem em:

- Cat Financial - serviço de crédito;

- Cat Insurance - serviço de proteção do equipamento contra danos;

- Cat Rental Stores - estabelece uma rede de revendedores com uma diversidade de soluções periódicas;

- Cat Logistics - serviço de planejamento e gestão de cadeias de suprimentos;

- Equipment Training Solutions Group - serviços cujo conteúdo engloba cursos de treinamento para o uso do produto focado na produtividade;

- Maintenance and Support - esses serviços englobam tanto o fornecimento de kits de manutenção quanto soluções com garantia de desempenho otimizado e custos reduzidos;

- Remanufacturing - serviços de recuperação, limpeza e reforma.

O sistema formado pelo bem tangível e os módulos de serviço podem se enquadrar tanto em uma relação comercial B2B quanto B2C. Dependendo do módulo empregado o sistema pode ser 
classificado como orientado ao bem tangível (serviços de crédito), ao uso (serviços de treinamento) ou orientado ao resultado (como os serviços logísticos).

Por se tratar de um serviço de ordem técnica, guardando coerência com a descrição do contexto, a Figura 24 ilustra a associação do bem tangível deste fabricante com o módulo de serviço de "manutenção". Portanto a adição de valor ocorre com a aplicação das atividades de manutenção. Essa figura representa um contexto que engloba os fluxos físicos e de informação, essa última com origem do consumidor. A coleta de dados referentes ao valor, ao uso e ao desempenho desse produto que podem orientar a atuação nos parâmetros de desempenho como a eficiência dos equipamentos ou melhorias nos atributos de operação. Contudo as melhorias também podem ser orientadas à viabilização dos serviços, não só pela facilidade de manutenção que pode ser conferida ao artefato físico por orientações de desenvolvimento específicas, como o aperfeiçoamento dos próprios procedimentos de serviços.

Figura 24 - Ilustração pictórica do caso de referência

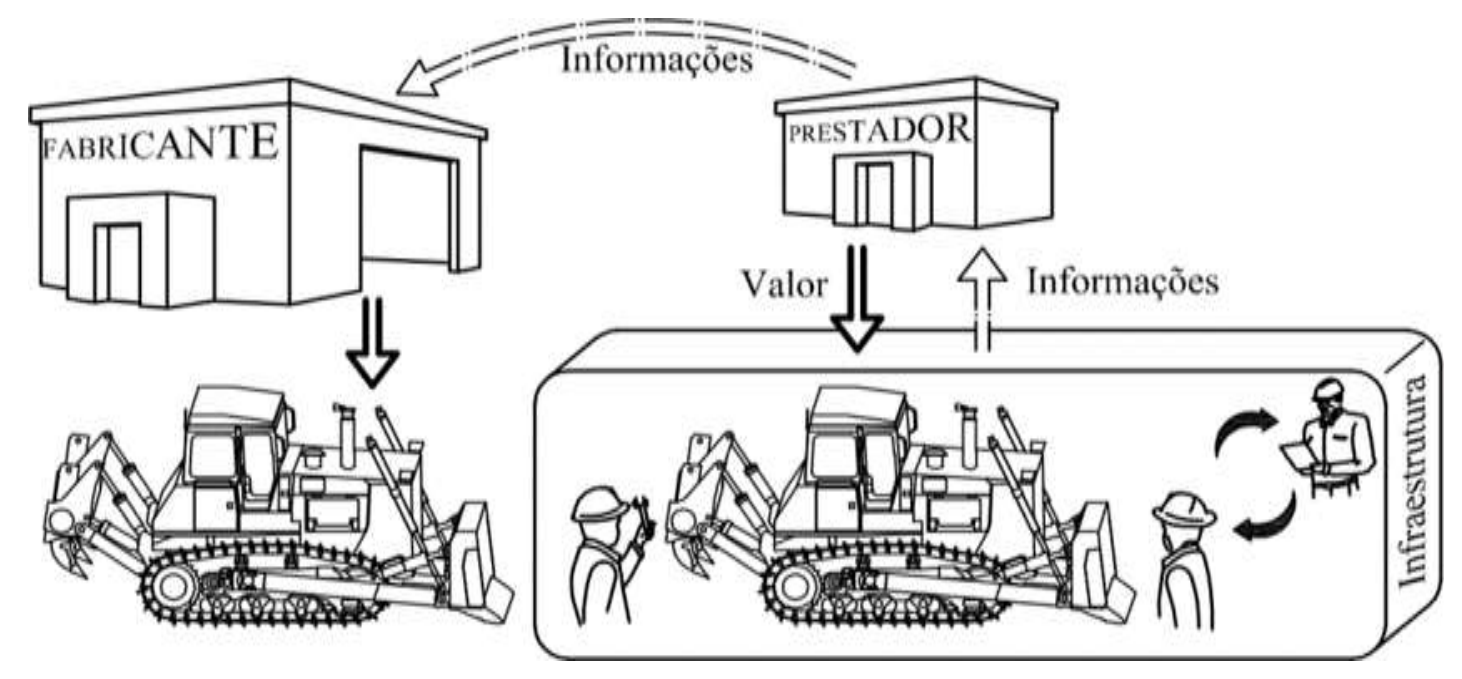

Fonte: o autor.

A representação da Figura 24 utiliza a estrutura ilustrativa já empregada na fundamentação teórica referente à organização do PSS evidenciando a organização dos stakehoders para a entrega do valor. Nesse sentido o fabricante é representado disponibilizando o valor referente ao bem tangível no sistema enquanto que um módulo de serviço, nesse caso referente a serviços técnicos de manutenção, é agregado na extensão da rede de criação de valor. Também conforme o contexto, o ingresso no sistema ocorre com a aquisição do artefato físico. Então, o pacote de valor nesse caso corresponde aos benefícios proporcionados pelo equipamento adicionados dos benefícios resultantes das 
atividades de manutenção como, por exemplo, o aprimoramento do desempenho desse equipamento.

Para os fins de simulação os valores empregados ao modelo e que definem a interação entre esses stakeholders são adotados em coerência aos dados utilizados para os testes. Esses valores são todos explicitados nas seções referentes a própria simulação computacional.

Outros casos de referência também poderiam ser apontados como, por exemplo, o sistema denominado "Total-Care Package" (BAINES et al., 2007), mas também referenciado na literatura por "Power by the Hour", englobando o fabricante Rolls-Royce responsável pela produção de turbinas para o segmento aeronáutico. Outro exemplo envolve o fabricante de máquinas de lavar roupas Electrolux (BAINES et al., 2007) que com a agregação de serviços passa a comercializar "soluções em lavagem". Neste a relação comercial ocorre no contexto B2C e também é caracterizada pela agregação de serviços técnicos. Também Sistemas Produto-Serviço enquadrados em outros segmentos industriais como o caso Parkersell (MEPSS WEBTOOL, [2011?]) realizado com o emprego da metodologia para desenvolvimento de PSS MePSS. Assim, apesar da diversidade que os Sistemas Produto- Serviço podem assumir a perspectiva desenvolvida oferece uma possibilidade de representação genérica de certos casos citados na literatura.

\subsection{CONSIDERAÇÕES PARA A SIMULAÇÃO}

A simulação computacional utilizando o modelo quantitativo permite analisar o comportamento de um sistema e testar ações frente ao seu desempenho em um "mundo virtual" (STERMAN, 2000). De maneira prática, a simulação permite estimar o impacto da alteração das variáveis de entrada nas variáveis de saída. Neste ponto de vista, conforme representado na Figura 25, o comportamento do sistema pode ser representado genericamente pela saída (S) ou consequência como uma função das variáveis de entrada (E) e das variáveis de ação (VA). Essas últimas representam os meios pelos quais se pode intervir no sistema. Esse comportamento pode ser observado ou monitorado com auxílio das variáveis essenciais (VE), que são variáveis de interesse a análise e que podem levar a certas conclusões sobre tal comportamento. 
Figura 25- Representação genérica de um sistema

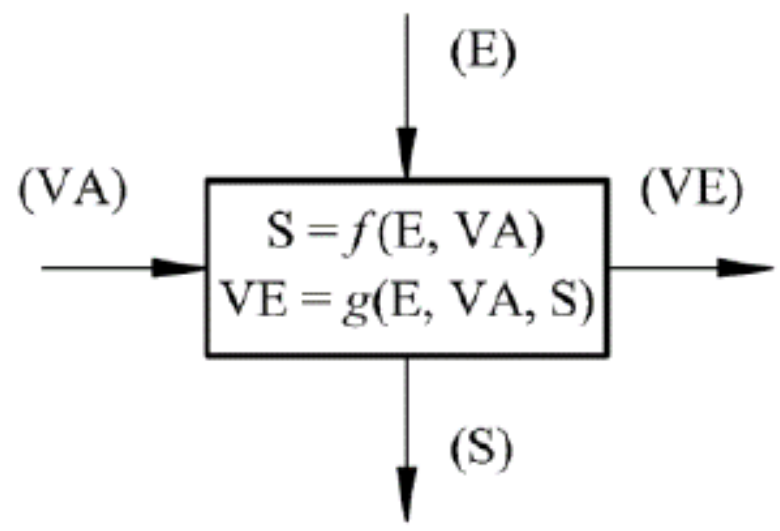

Fonte: Mélèse (1973).

Classificando as variáveis utilizadas no modelo conforme o expresso anteriormente, as entradas do sistema (E) consistem nas restrições operacionais para a atuação no bem tangível e no serviço. Além destas também é considerada variável de entrada a expectativa da qualidade (bem tangível e serviço) que viabilizam a indução das condições desfavoráveis descritas na seção seguinte. E ainda a demanda de referência ao subsistema de produção também como fator de viabilização da simulação. Ou seja, as variáveis de entrada do modelo são oriundas, em parte, do conhecimento da capacidade dos subsistemas envolvidos, como também das informações coletadas nos processos anteriores de desenvolvimento do PSS referentes às preferências e valores do grupo de consumidores de interesse, e ainda de fatores que viabilizam a simulação.

Já as variáveis de ação (VA) consistem nos fatores dinâmicos influenciados pelos parâmetros e características atribuídos ao produto e definidos pelos métodos e ferramentas específicas na atividade de desenvolvimento deste. No ponto de vista de análise e pelo modelo proposto esses fatores se referem aos principais parâmetros operacionais considerados dos subsistemas de produção (o tempo de ciclo) e prestação (o tempo de prestação). Ou seja, se considera que os esforços de desenvolvimento do produto podem ser direcionados para dois principais objetivos: reforçar a eficiência da produção dos artefatos físicos e reforçar a eficiência da prestação dos serviços associados.

As variáveis essenciais (VE) fornecem os indicadores do sistema. Na estrutura do modelo essas variáveis representam o estado dos três subsistemas no contexto dinâmico. Então, para o subsistema de produção as VE consistem no nível de "trabalho em processo" e no nível de "artefatos disponíveis". Para o subsistema de prestação essas variáveis correspondem ao nível de "consumidores em espera" 
e no nível de "consumidores em processo". Já para o subsistema de consumo têm-se os indicadores de "qualidade percebida (bem tangível)" e "qualidade percebida (serviço)".

Já a variável de saída (S) englobada pelo subsistema de prestação corresponde ao número final de "consumidores processados". Nesta simulação essa variável corresponde ao número de pacotes de valor entregues. Essa classificação das principais variáveis e constantes do modelo está sintetizada no Quadro 7.

Quadro 7 - Classificação dos principais fatores do modelo

\begin{tabular}{|c|l|}
\hline Tipo & \multicolumn{1}{|c|}{ Variáveis e constantes do modelo } \\
\hline & $\begin{array}{l}\text { Expectativa de qualidade (bem tangível) } \\
\text { Expectativa de qualidade (serviço) } \\
\text { Tempo de correção da qualidade percebida (bem tangível) } \\
\text { Tempo de correção da qualidade percebida (serviços) } \\
\text { Demanda de referência } \\
\text { Defasagem da demanda por serviços }\end{array}$ \\
\hline (VA) & $\begin{array}{l}\text { Tempo de ciclo de produção } \\
\text { Tempo de prestação }\end{array}$ \\
\hline (VE) & $\begin{array}{l}\text { Qualidade percebida (bem tangível) } \\
\text { Qualidade percebida (serviço) } \\
\text { Artefatos disponíveis } \\
\text { Trabalho em processo } \\
\text { Consumidores em espera } \\
\text { Consumidores em processo }\end{array}$ \\
\hline
\end{tabular}

Fonte: o autor.

Como evidenciado no Quadro 7 a simulação tem base em uma demanda de referência. Para os fins de simulação deste modelo, evidenciando as ações de ajuste do sistema pelos ciclos de realimentação e dando condições para que o sistema seja analisado em diferentes níveis de solicitações, a demanda de referência (DR) foi representada por uma função senoidal variando entre os picos de 10 e 20 artefatos/semana no período de um ano. Isto é descrito na Equação 1 utilizando a variável de tempo (t) que no ambiente de simulação insere o intervalo de integração e nesse modelo é dado em 
"semanas". Ainda, como mostrado nessa equação, a demanda de referência está condicionada à percepção do consumidor da qualidade referente ao bem tangível (inserida pelo termo QSA). Conforme abordado a qualidade satisfeita referente ao bem tangível (QSA) é função da percepção e da expectativa da qualidade segundo o consumidor. Este termo é inserido na equação referente à DR como condicionante para o ingresso no sistema, assim como a taxa de adesão está condicionada à percepção da qualidade do serviço.

$$
D R=\left\{15+\left[5 \cdot \sin \left(2 \cdot \pi \cdot \frac{t}{12}\right)\right]\right\} \cdot Q S A
$$

A demanda por serviços, modelada pela relação de um artefato gerando um consumidor, mantém o mesmo valor que a demanda de referência. Como o emprego dos serviços se dá com uma defasagem de tempo da aquisição dos artefatos a demanda por serviços é inserida utilizando a função "DELAY FIXED" no emprego do software Vensim PLE. Por isso no Quadro 7 e também nos tópicos posteriores tratando as projeções de cenários é feita referência à "defasagem da demanda por serviços". Os valores das constantes do modelo são expostos no tópico referente à projeção dos cenários, contudo, salienta-se que a análise desses cenários o foco está no comportamento gráfico no tempo das VE e da saída. Diferentes valores de constantes produziriam cenários com amplitudes e defasagens diferentes, porém ainda com a mesma característica do comportamento de seus fatores no tempo.

O método de integração "Euler" foi empregado para em todas as projeções de comportamento simuladas. Também como configuração específica para a simulação Forrester (1961) recomenda para a definição do intervalo de integração (dt) a utilização de 1/4 a 1/10 do valor da menor constante de tempo integrante do modelo. Respeitando essa recomendação o intervalo de integração foi utilizado como $1 / 5$ do valor da menor constante de tempo. Como as diferentes condições de simulação podem utilizar constantes de tempo variadas o valor específico do intervalo de integração é indicado para as projeções em específico. Essas diferentes condições são explanadas na sequência, na seção específica acerca da simulação computacional realizada.

\subsection{SIMULAÇÃO COMPUTACIONAL}

A simulação proposta nesta análise consiste em (i) inicialmente ajustar as constantes utilizadas para que o sistema acompanhe a demanda de referência. Assim, o sistema reproduz um comportamento favorável de referência, robusto e isento de erros específicos da utilização da linguagem de modelamento. Na sequência da simulação, tendo em vista que o comportamento dinâmico pode ser 
considerado como as reações diversas às perturbações que afetam o desempenho do PSS impondo algum risco a este (PHUMBUA; TJAHJONO, 2011), (ii) os fatores de interferência no sistema são configurados para condições desfavoráveis. A Figura 26 ilustra por um esboço o desempenho dinâmico da entrega de valor observando as pressuposições da demanda de referência como uma representação senoidal.

Figura 26 - Esboço do desempenho dinâmico da entrega de valor

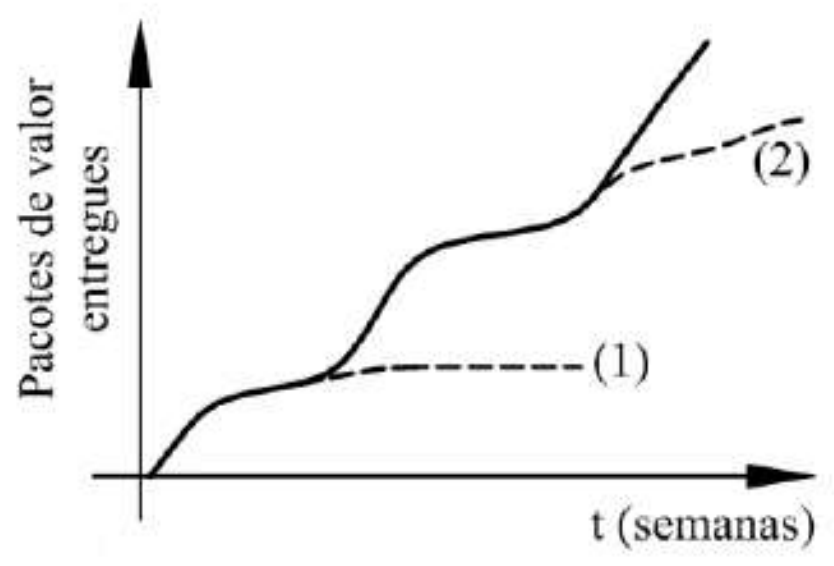

\section{Legenda:}

Comportamento esperado ---- Desvios

Fonte: o autor

Nesse desempenho, como é mostrada na Figura 26, a condição favorável produz um "comportamento esperado" em que a quantidade de pacotes de valor entregues apresenta sempre algum crescimento determinado pela demanda de referência. Já para as condições desfavoráveis são deduzidos dois desvios em que o desempenho do sistema é tido como indesejável: (1) quando não há um aumento da quantidade de pacotes de valor entregues e (2) quando o aumento da quantidade de pacotes de valor entregues é menor que o esperado. Uma estratégia de simulação semelhante, considerando a comparação entre cenários favoráveis e desfavoráveis também é adotada por Mattos, et al (2019) e Ariente Neto e Forcellini (2020). Na sequência, são conduzidas as simulações projetando cenários específicos de interesse para a análise. Os valores das constantes utilizadas na simulação são devidamente expostos, contudo, sendo a estrutura do sistema (definida pelo modelo proposto) o determinante para o seu comportamento, a análise dos cenários consiste na interpretação do comportamento gráfico no tempo das variáveis essenciais e da variável de saída. Como já salientado, o emprego de diferentes valores às constantes utilizadas na simulação produz diferentes defasagens e amplitudes, contudo o comportamento apresentado é análogo. 


\subsubsection{CONDIÇÃO FAVORÁVEL}

No cenário que representa a condição favorável de referência a percepção da qualidade oferecida pelo sistema é coerente com a expectativa de qualidade do consumidor. Portanto a expectativa de qualidade (referente ao bem tangível e ao serviço) é configurada para "1". As constantes de tempo do modelo permaneceram com os valores utilizados para os testes de validação do modelo. Além de reproduzirem o comportamento de referência estão em concordância com o exposto por Sterman (2000) em que o tempo de correção do estoque (demandando conferência e procedimentos específicos que consomem tempo e recursos) é sempre maior que o tempo para correção do trabalho em processo. Da mesma maneira o valor do tempo requerido para correção do trabalho em processo utilizado é superior ao tempo de ciclo. Isso também é aplicado ao subsistema de prestação em que já na etapa de testes o "tempo de correção dos consumidores em processo" utilizado é superior ao "tempo de correção dos consumidores em espera". A "defasagem da demanda por serviços" é definida para cinco semanas. Ainda, o intervalo de integração é definido em: $d t=1 / 5 \cdot 0,3=0,06$.

Com o software devidamente configurado a simulação é realizada. Como a demanda de referência exerce as solicitações ao subsistema produtivo então este subsistema é abordado inicialmente. Expondo a dinâmica apresentada por esse a Figura 27 apresenta a projeção gráfica do comportamento do indicador "trabalho em processo". Como não foram consideradas quantidades iniciais desse trabalho, assim como de artefatos disponíveis em estoque, o início de produção é mais acentuado. Apesar da estrutura de decisão demandar fatores de influência específicos para reproduzir a inércia de início de produção, com a ação do ciclo de controle do trabalho em processo sua variação passa a acompanhar a variação do próprio estoque de artefatos disponíveis dada pela demanda.

Assim como para o trabalho em processo também não foram consideradas quantidades iniciais de estoque de "artefatos disponíveis". Pela Figura 28 se pode verificar que à medida que o trabalho em processo é concluído passa a haver "disponibilidade de valor" para atendimento das solicitações ao sistema. A alimentação ao estoque é tal que compensa as retiradas pela demanda e conduz ao nível desejado, contudo flutuando pela ação de correção desse consumo. Assim, depois de decorrido um tempo o estoque de artefatos disponíveis passa a acompanhar as variações da demanda. Isso confere a disponibilidade de valor ao longo do horizonte de simulação. 
Figura 27 - Condição favorável: "trabalho em processo"

Condição favorável

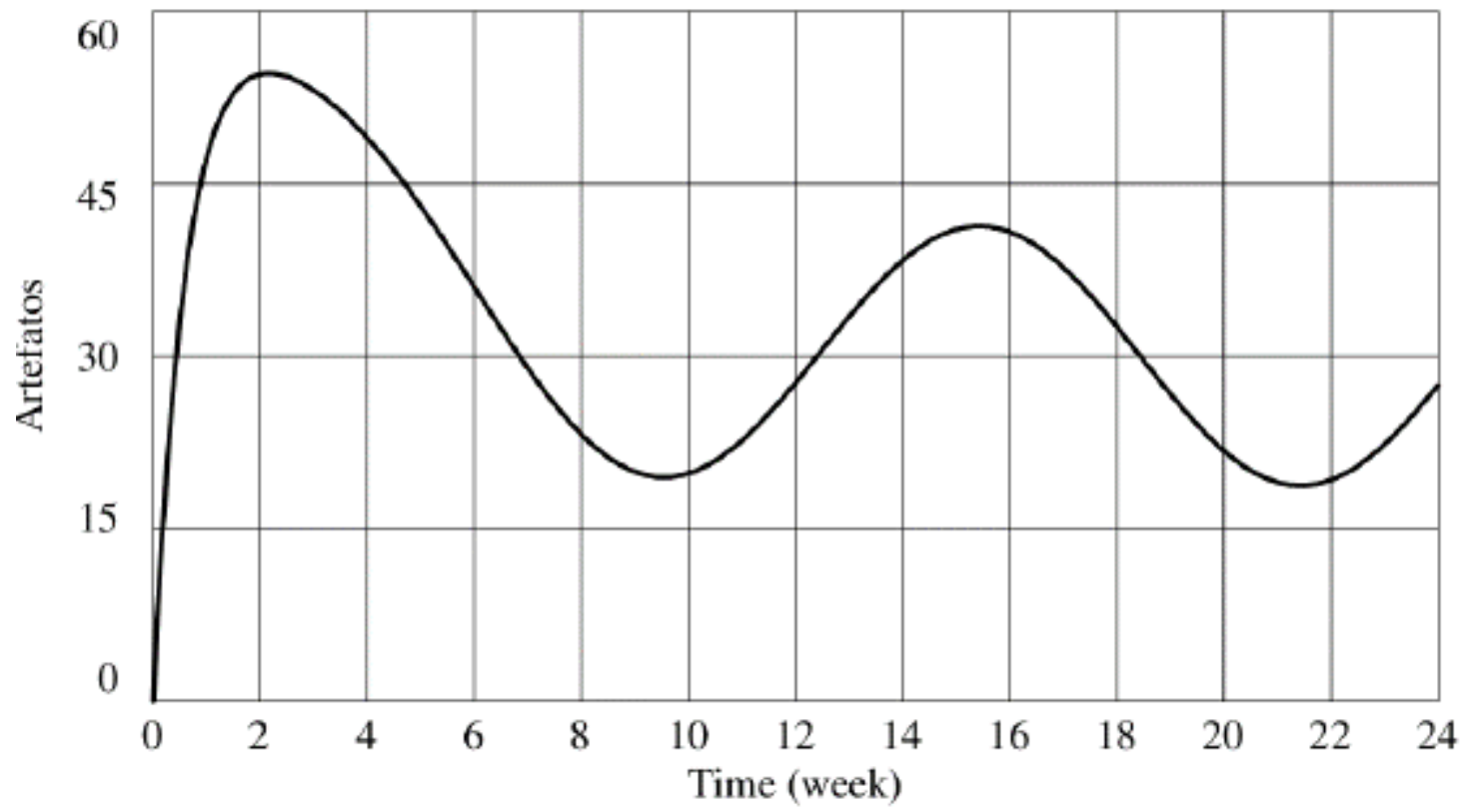

Trabalho em processo : Sim_cond_fav_2

Fonte: o autor.

Figura 28 - Condição favorável: "artefatos disponíveis"

Condição favorável

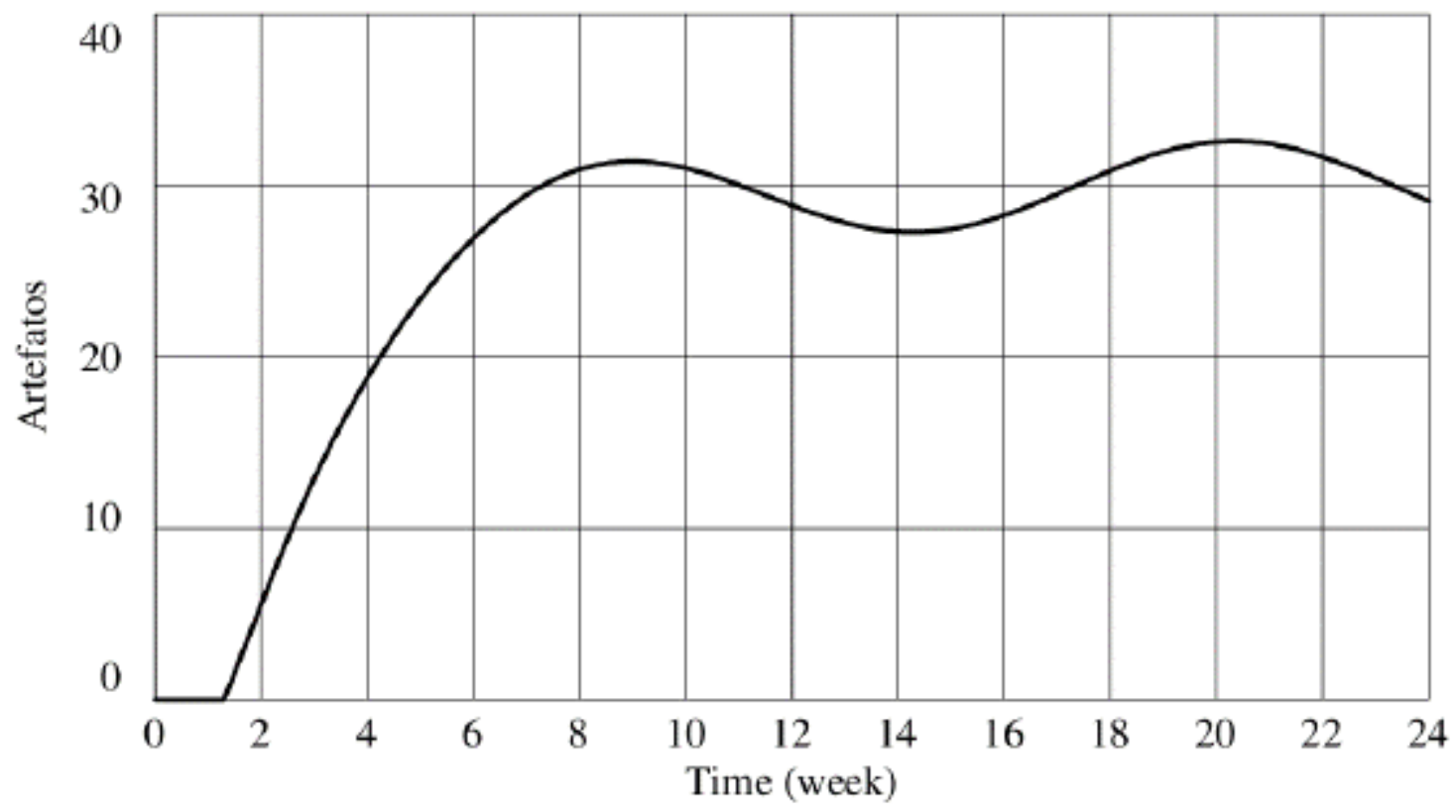

Artefatos disponíveis : Sim_cond_fav_2

Fonte: o autor. 
Mesmo não classificadas como VE, mas contribuindo para a compreensão dos gráficos anteriores, adicionalmente são mostradas na Figura 29 as representações gráficas da demanda e das taxas de início e conclusão da produção. Para a alocação do trabalho em processo e a condução do estoque de artefatos disponíveis para o acompanhamento da demanda a "taxa de início de produção" (sem restrições) tem um aumento súbito também provocando um aumento mais acentuado da "taxa de conclusão da produção" em virtude do estado inicial da produção. A taxa de início da produção apresenta uma defasagem ao longo do horizonte de simulação em relação à taxa de conclusão e à demanda de referência. Essa defasagem ocorre em função do tempo de ciclo de produção e do tempo demandado para a correção do trabalho em processo. Já a "taxa de conclusão da produção" ao longo do horizonte de simulação aproxima-se do valor da demanda ao sistema produtivo.

Figura 29 - Condição favorável: taxas (subsistema de produção)

\section{Condição favorável}

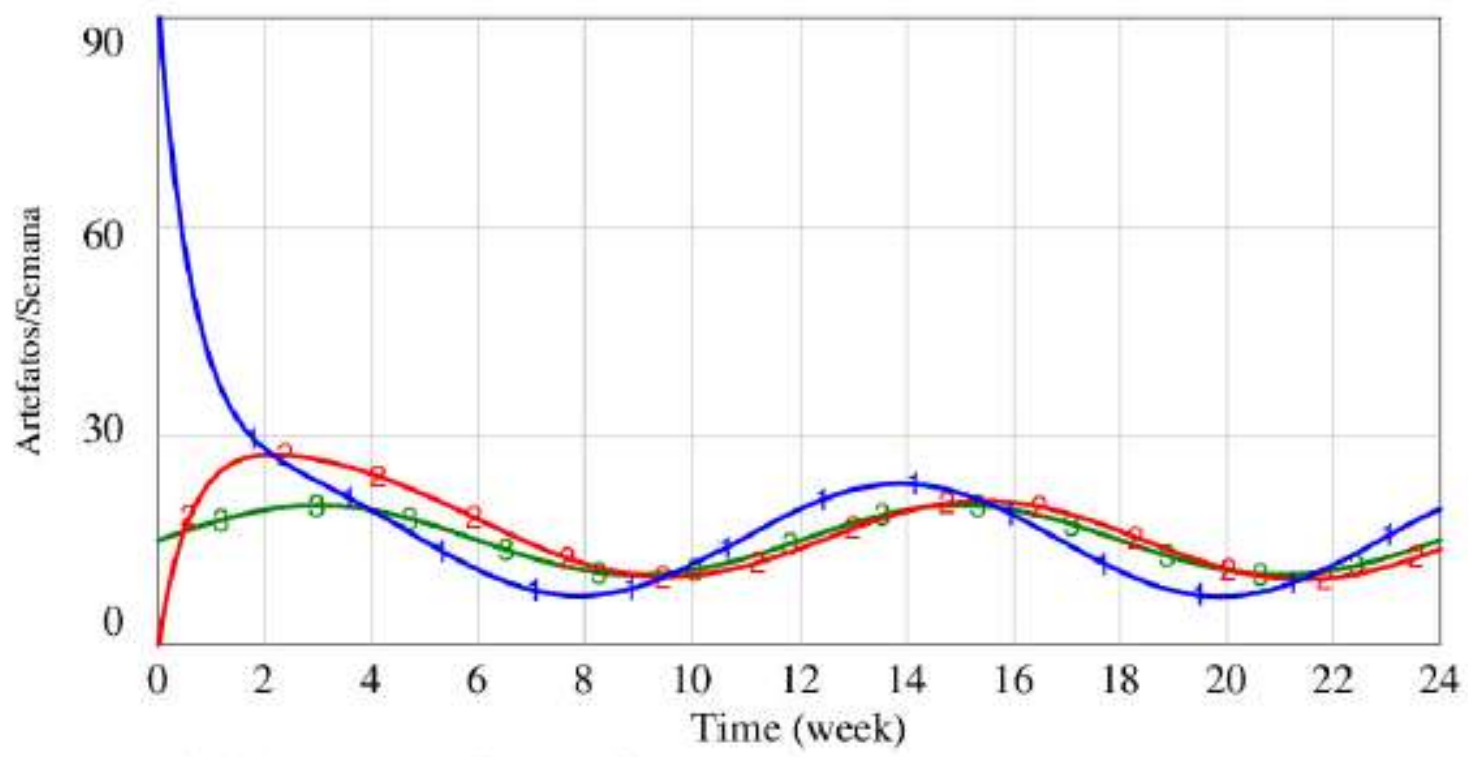

Taxa de início de produção : Sim_cond_fav Taxa de conclusão da produção: Sim_cond_fa Demanda de referência : Sim_cond_fav

Fonte: o autor.

Já referente ao subsistema de prestação, como representado na Figura 30, a atuação do controle de prestação ocorre com a solicitação pela "demanda por serviços". Como essa demanda é inserida com uma defasagem em relação à demanda por produtos de cinco semanas essa relação fica evidenciada uma vez que o processamento dos consumidores inicia na quinta semana do horizonte de simulação. Também não sendo considerados consumidores em processo no instante inicial o aumento destes se 
inicia do valor "zero", gradualmente processa o pico inicial de consumidores e ao longo do horizonte ajusta-se à demanda por serviços.

Figura 30 - Condição favorável: "consumidores em processo"

\section{Condição favorável}

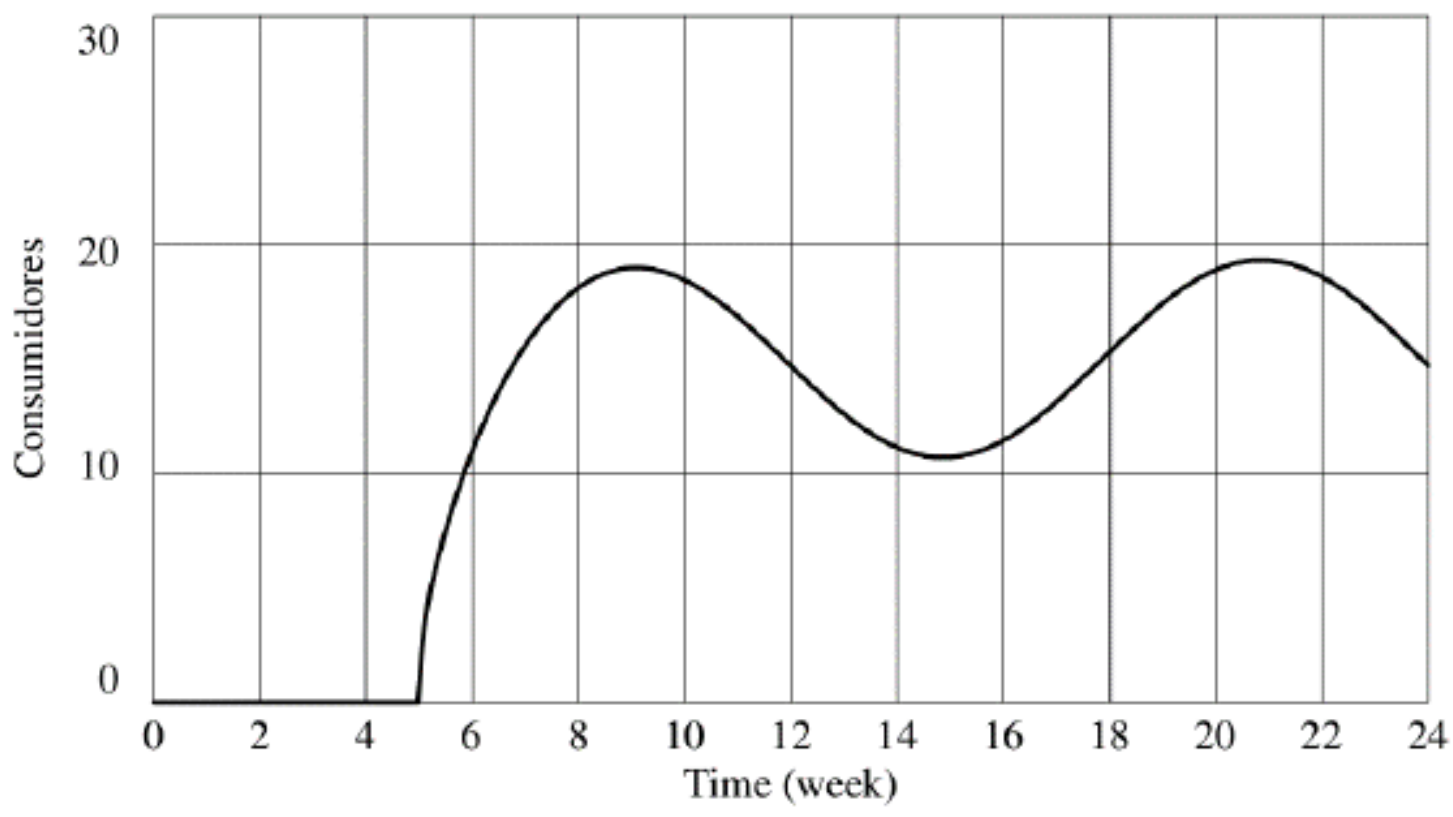

Consumidores em processo : Sim_cond_fav

Fonte: o autor.

A partir do comportamento discutido relativo à projeção gráfica das VE do modelo o comportamento apresentado pela saída do sistema (os consumidores processados que nesse contexto representa a entrega do pacote de valor) também pode ser analisado. Como pode ser observada pelo comportamento gráfico representado na Figura 31 a entrega de valor inicia-se com a conclusão do processamento dos primeiros consumidores. Portanto, pode ser distinguida uma pequena inércia no aumento da quantidade de consumidores processados em função da configuração inicial do modelo e da estrutura de decisão que o controla. Contudo, a quantidade de consumidores processados passa a aumentar determinada pela taxa da demanda e pelas constantes do sistema. 
Figura 31 - Condição favorável: "consumidores processados"

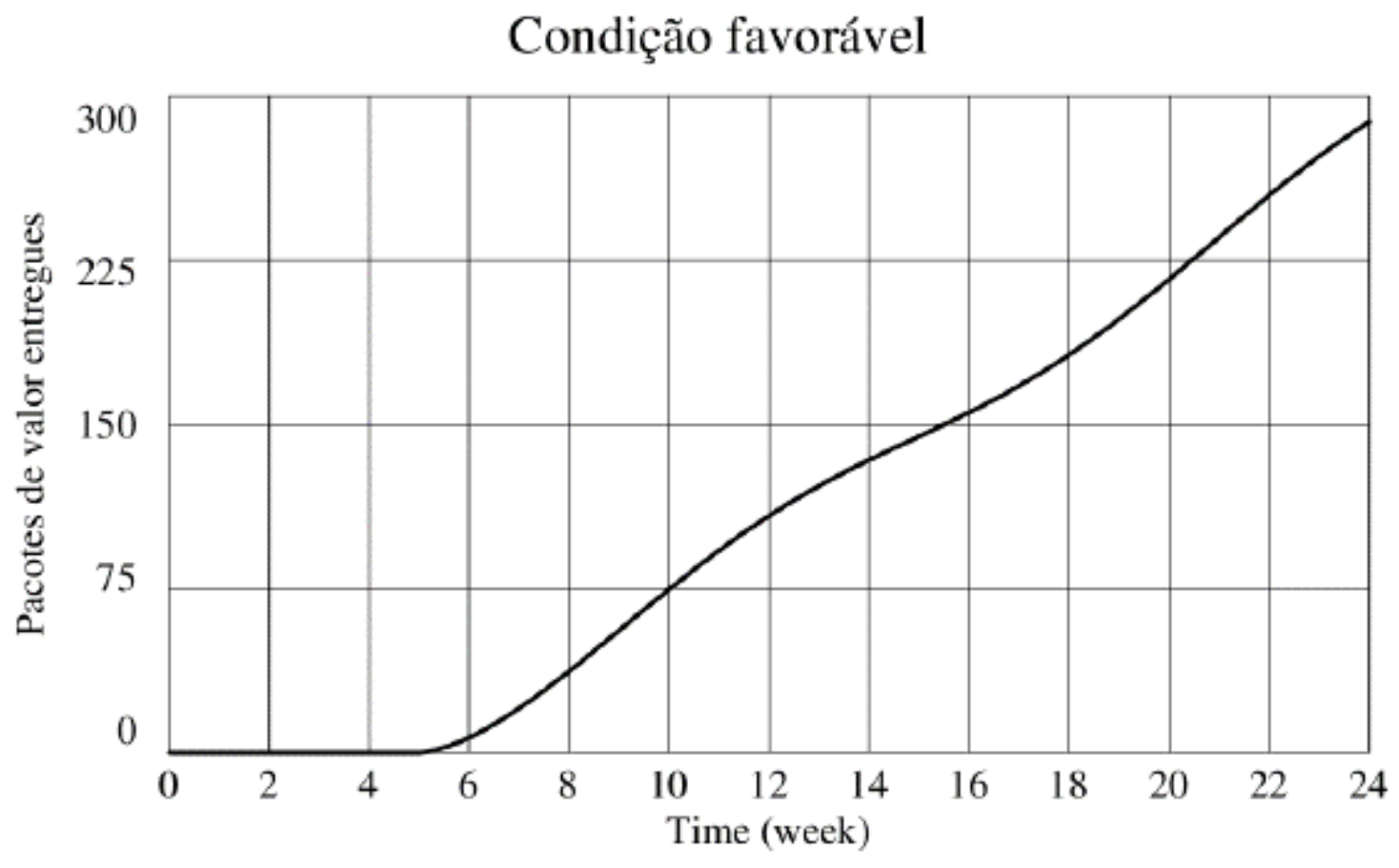

Consumidores processados : Sim_cond_fav

Fonte: o autor.

A quantidade de "consumidores processados" ao longo do horizonte de simulação conduzida para a condição favorável apresenta o comportamento esperado de crescimento. As variações desse crescimento se devem às diferentes taxas de produção e processamento orientadas pela flutuação senoidal induzida para a "demanda de referência". Isso é viabilizado pelas estruturas sistêmicas atuando para prover a "disponibilização do valor" e o "processamento de consumidores" e, portanto, contribuindo com a facilidade de obtenção e consumo do valor.

Nessa condição favorável, contudo, a percepção da qualidade entregue permaneceu constante e igual à expectativa. Condições diferentes dessa são abordadas nas condições desfavoráveis expostas na sequência.

\subsubsection{CONDIÇÃO DESFAVORÁVEL (BEM TANGÍVEL)}

As condições desfavoráveis são estabelecidas quando a expectativa da qualidade supera a percepção da qualidade que pode ser dada como reflexo da entrada no mercado de um produto, serviço ou um novo sistema similar ou concorrente. Conforme o modelo proposto essa expectativa pode ser relativa ao bem tangível ou ao serviço. Portanto, em um primeiro momento a simulação é conduzida como na condição favorável, mas com a indução de um aumento de $30 \%$ na expectativa da qualidade relativa 
ao bem tangível. Essa indução é feita no instante 12 (semanas). O intervalo de integração utilizado para a projeção do comportamento continuou definido para 0,06 .

Nessa condição o incremento na expectativa gera uma diferença entre essa e a percepção da qualidade havendo, então, a atuação do ciclo de "controle da qualidade do bem tangível" na condução da percepção para um novo estado de igualdade. A Figura 32 representa a intervenção no bem tangível com sua consequência na percepção da qualidade do consumidor resultante da atuação do ciclo de controle. Como a satisfação com a qualidade é uma condicionante da demanda ao sistema produtivo essa demanda é interrompida no instante de indução do acréscimo na expectativa.

Figura 32 - Condição desfavorável (bem tangível): “expectativa e percepção da qualidade"

\section{Condição desfavorável}

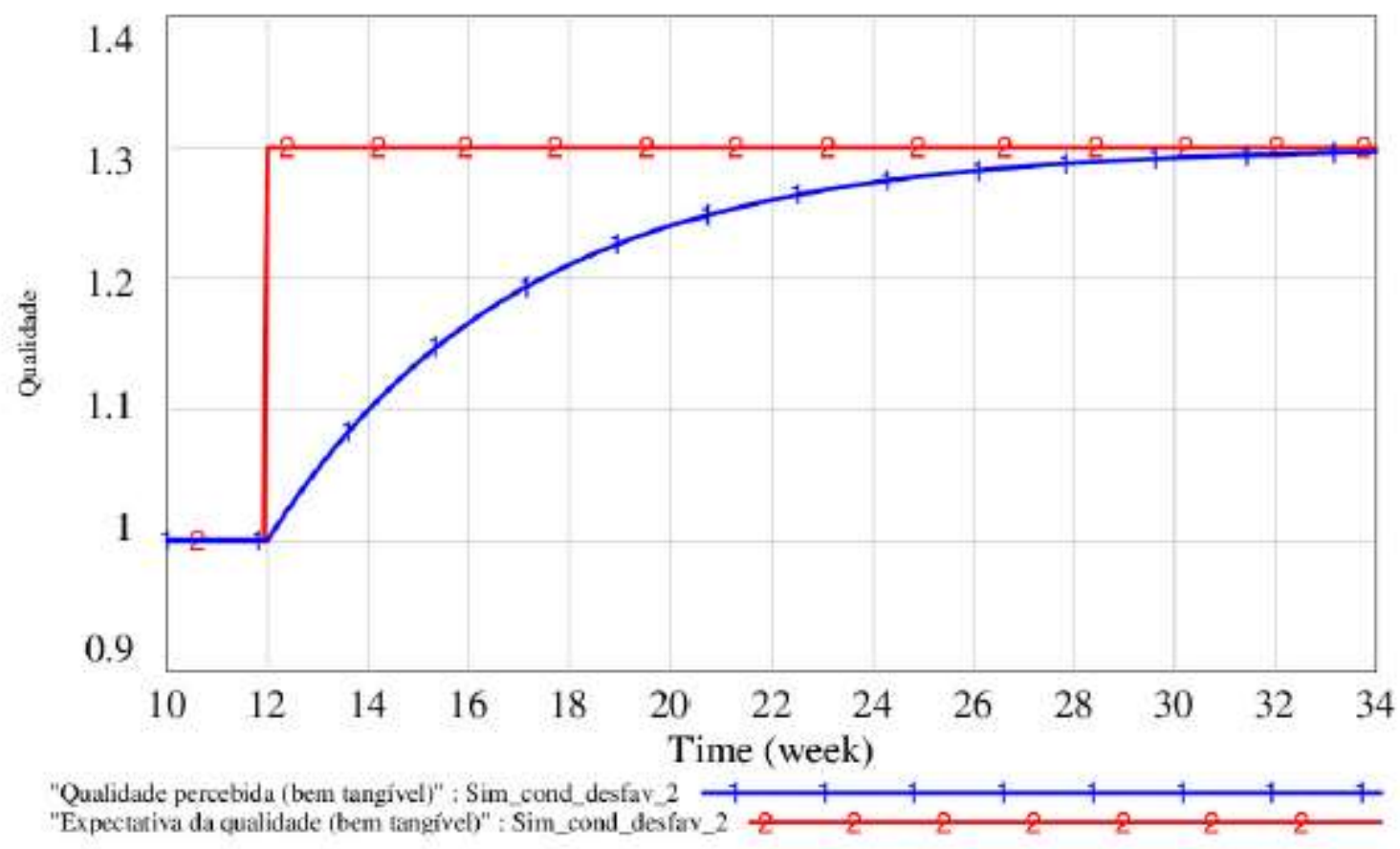

Fonte: o autor.

Com a interrupção da demanda ao sistema produtivo a "taxa de entrega" que acompanhava a flutuação senoidal da demanda de referência também é interrompida. Frente a esse evento a estrutura de decisão que constitui o modelo proposto interrompe o início da produção sendo que o "trabalho em processo" já existente é concluído pela "taxa de conclusão da produção" que tem uma redução gradual até o término do estoque de trabalho em processo. Esse comportamento é mostrado na Figura 33 com a representação da evolução do trabalho em processo, sendo que, com a obtenção do estado de satisfação com a qualidade do produto são retomadas as solicitações ao sistema produtivo. Nesse caso, o nível de trabalho em processo passa a novamente aumentar com a atuação 
do ciclo de "controle do trabalho em processo". Esse modelo simplifica muitas questões que poderiam estar envolvidas visto que não são consideradas, por exemplo, condições intermediárias do efeito da percepção da qualidade na demanda pelos produtos, ou restrições de capacidade dos subsistemas. Também políticas alternativas diversas podem ser empregadas para o controle do material em processo neste caso desfavorável.

Figura 33 - Condição desfavorável (bem tangível): "trabalho em processo"

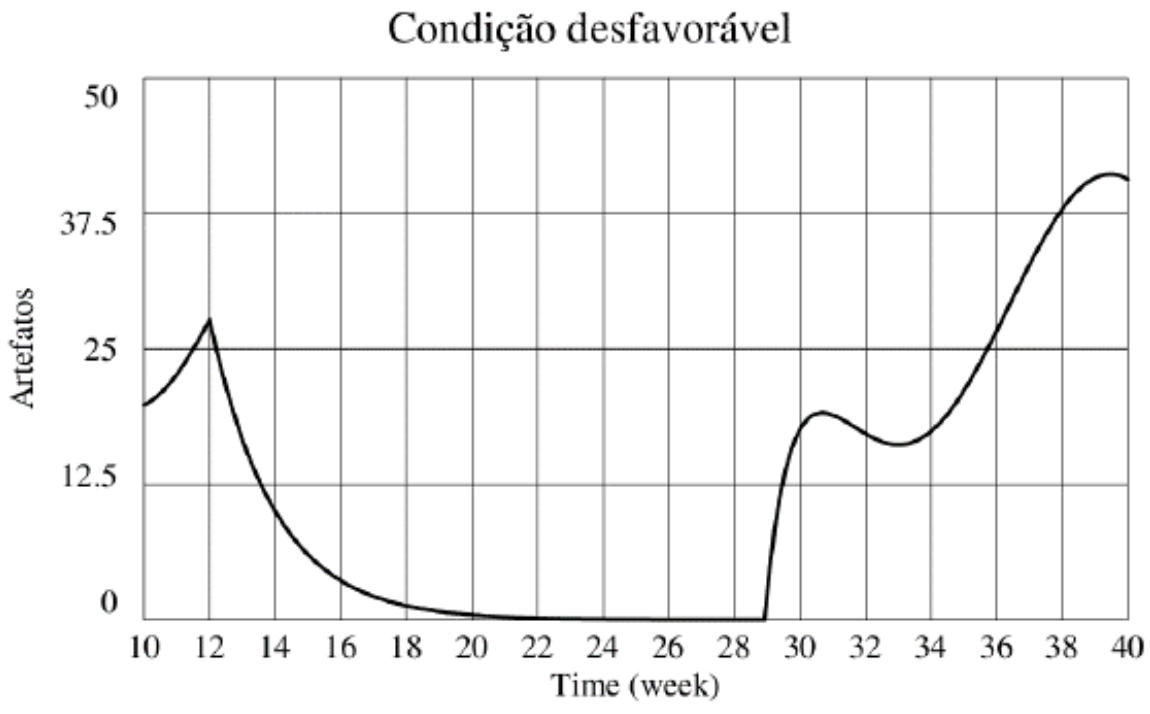

Trabalho em processo : Sim_cond_desfav_2

Fonte: o autor.

Em função da estrutura de decisão considerar a conclusão do trabalho já em processo no instante em que a taxa de entrega em valor passa a ser nulo o nível de "artefatos disponíveis" ainda tem um acréscimo. Na retomada da taxa de entrega é considerado o consumo dos itens acabados (situação ilustrada pelo comportamento apresentado na Figura 34). Contudo para casos em que as correções não podem ser agregadas aos artefatos já acabados e mesmo ao trabalho em processo, a nova confecção desses pode se fazer necessária, consistindo em um caso crítico. Também, em função dos valores atribuídos às constantes de tempo integrantes do modelo, na simulação conduzida a amplitude da interrupção ao sistema produtivo conduz o trabalho em processo ao nível nulo, o que pode não ser praticado visto que políticas alternativas podem ser aplicadas nesta situação. 
Figura 34 - Condição desfavorável (bem tangível): "artefatos disponíveis"

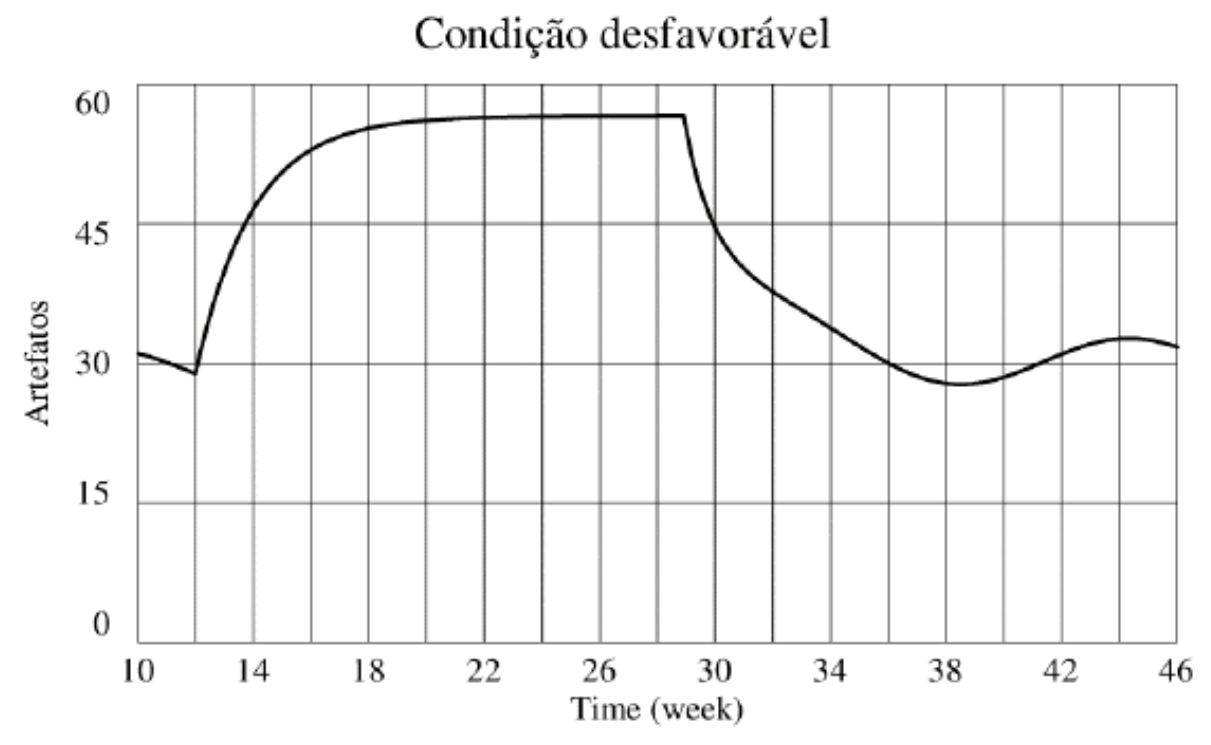

Artefatos disponíveis : Sim_cond_desfav_2

Fonte: o autor.

O reflexo da redução da demanda por serviços ocorre com a defasagem fixa considerada nesse modelo. Da mesma maneira os consumidores já em processo têm sua conclusão gradativa até o novo reflexo da retomada das solicitações ao sistema. Com a retomada da demanda por bens tangíveis vista a defasagem novos consumidores ingressam também no subsistema de prestação e o nível de "consumidores em processo" volta a acompanhar a flutuação da demanda com a ação dos ciclos de controle. Também neste caso podem estar envolvidas políticas alternativas, mas são reproduzidas pela simulação as considerações conceituais de influência entre os subsistemas de produção e prestação. A Figura 35 representa a falta de demanda ao subsistema de prestação e sua retomada. 
Figura 35 - Condição desfavorável (bem tangível): "consumidores em processo"

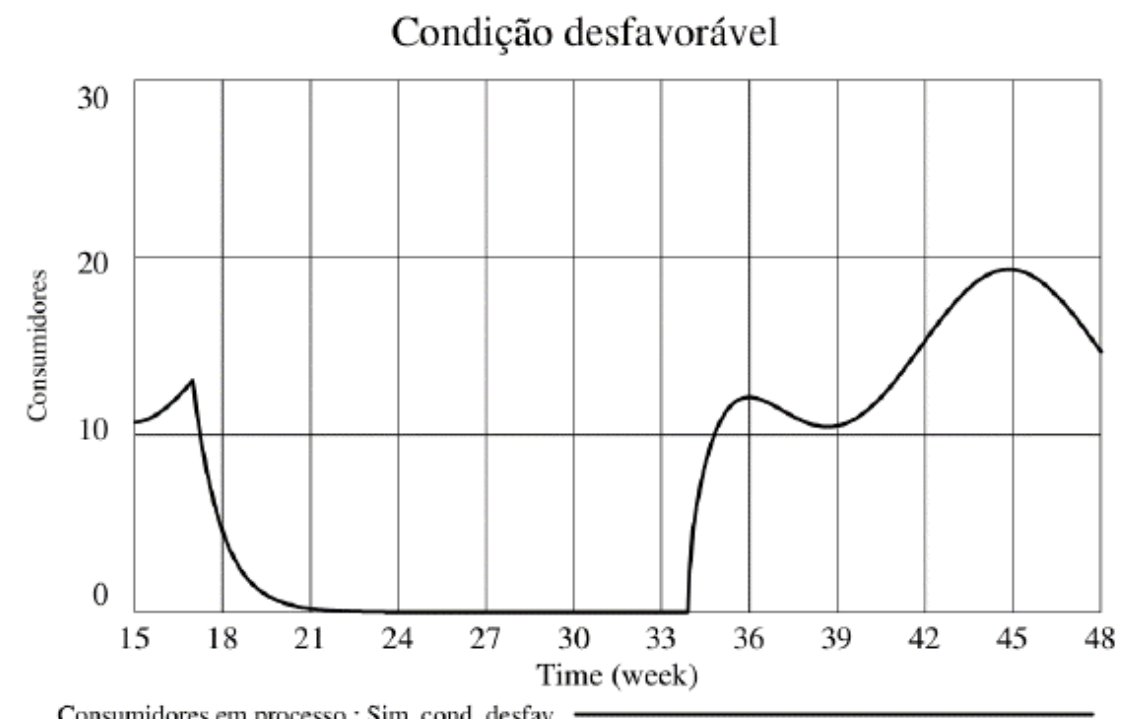

Fonte: o autor.

Conforme as descrições anteriores referentes às variáveis essenciais analisadas o comportamento dessas pode agregar outros fatores de influência de estruturas de decisões específicas. Nesta simulação a estrutura sistêmica responsável pela correção da qualidade do bem tangível conduz o sistema novamente ao comportamento esperado. Essa estrutura representa a atuação da atividade de desenvolvimento no contexto de realização do PSS. A Figura 36 evidencia os desvios gerados por um acréscimo na expectativa do consumidor referente ao bem tangível oferecido pelo sistema na quantidade de consumidores processados. 
Figura 36 - Condição desfavorável (bem tangível): "consumidores processados"

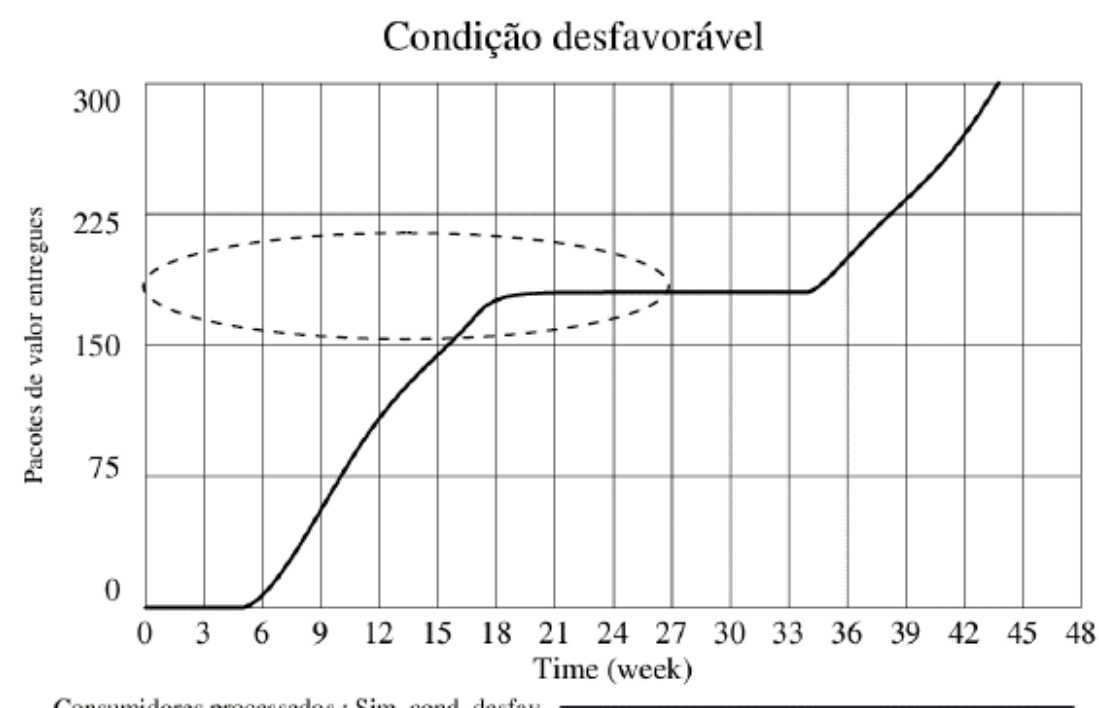

Fonte: o autor.

Mas, como salientado anteriormente em relação ao comportamento do estoque de artefatos disponíveis um caso crítico consiste na impossibilidade de agregação das correções de qualidade aos artefatos concluídos e ao trabalho em processo. Frente a essa questão um novo cenário é projetado considerando a "perda" do estoque de artefatos disponíveis e do trabalho em processo quando da indução do incremento na expectativa. Contudo, nesse cenário a correção da qualidade do produto agrega também uma redução do tempo necessário para a confecção do produto (o tempo de ciclo). Essa consideração, conforme ilustrado no diagrama conceitual, reside na possibilidade de ênfase à confecção do artefato físico com a aplicação das práticas e princípios de desenvolvimento do produto conforme as abordagens específicas DFX (nas quais se enquadrariam, por exemplo, o DFM e/ou o DFA). Assim, pode ser verificado o reflexo da atuação no bem tangível para, além de conferir o novo patamar de qualidade desejado também favorece a disponibilidade de valor no sistema. Nesse sentido, para a comparação dos cenários a Figura 37 mostra a retomada da produção para um estoque nulo de artefatos disponíveis considerando um tempo de ciclo de 2 (semanas) após a obtenção do novo patamar exigido à percepção de valor. 
Figura 37 - Condição desfavorável (bem tangível): "trabalho em processo" para TeC=2sem.

\section{Condição desfavorável}

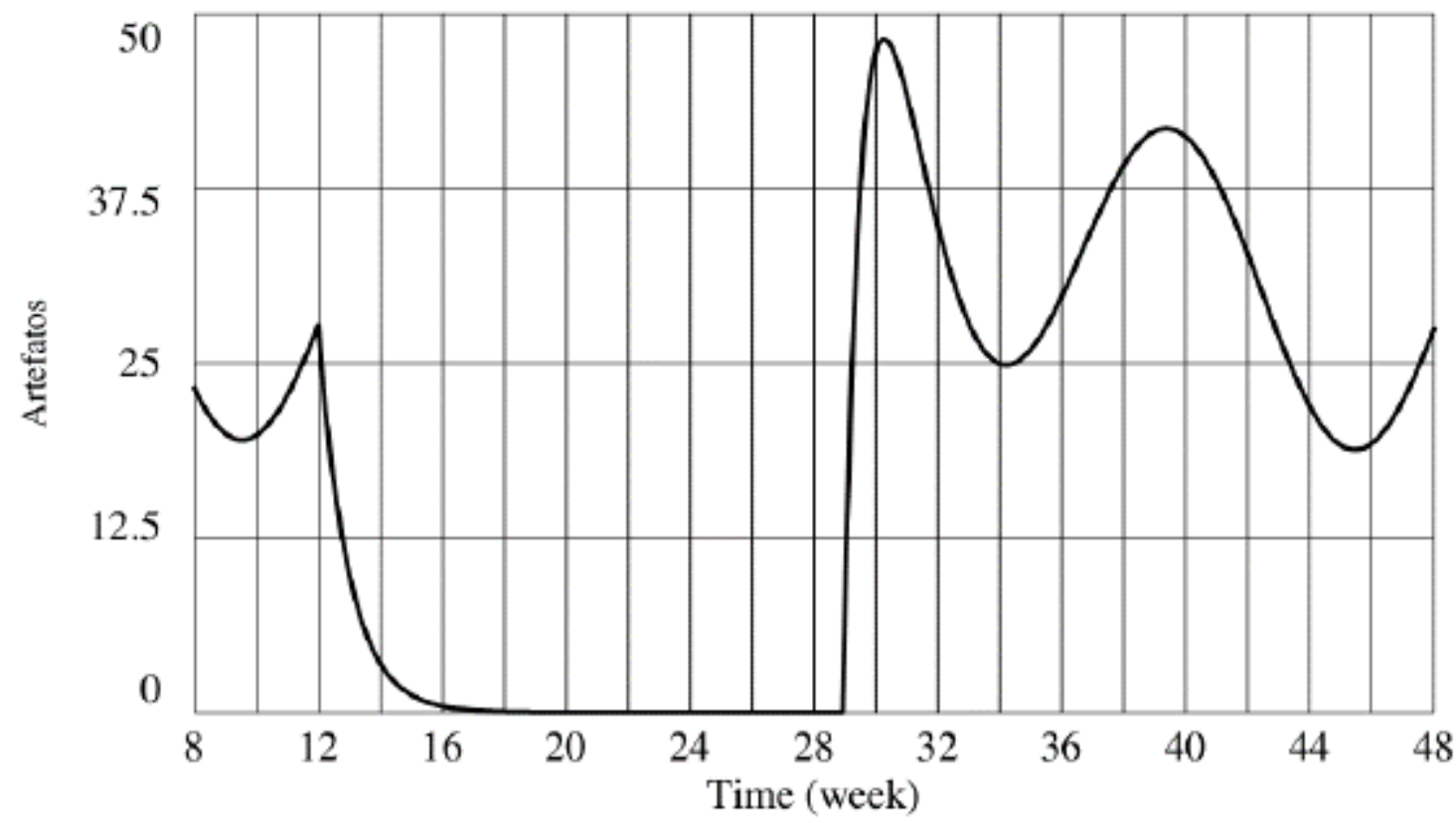

Trabalho em processo: Sim_cond_desfav_TC2-0-2

Fonte: o autor.

O tempo de ciclo de duas semanas consiste na condição original de simulação, não considerando sua redução. Assim, em contraponto a Figura 38 ilustra a mesma situação de retomada de produção com estoque nulo, contudo, com o $\mathrm{TeC}$ reduzido para uma semana como resultante da intervenção no produto.

Como se poderia pressupor a retomada da produção engloba uma menor quantidade de "trabalho em processo", proporcional à redução do tempo de ciclo. Como não é considerado o acúmulo da população referente à demanda de referência o comportamento do sistema engloba apenas a retomada ao atendimento dessa demanda. 
Figura 38 - Condição desfavorável (bem tangível): "trabalho em processo" para TeC=1sem.

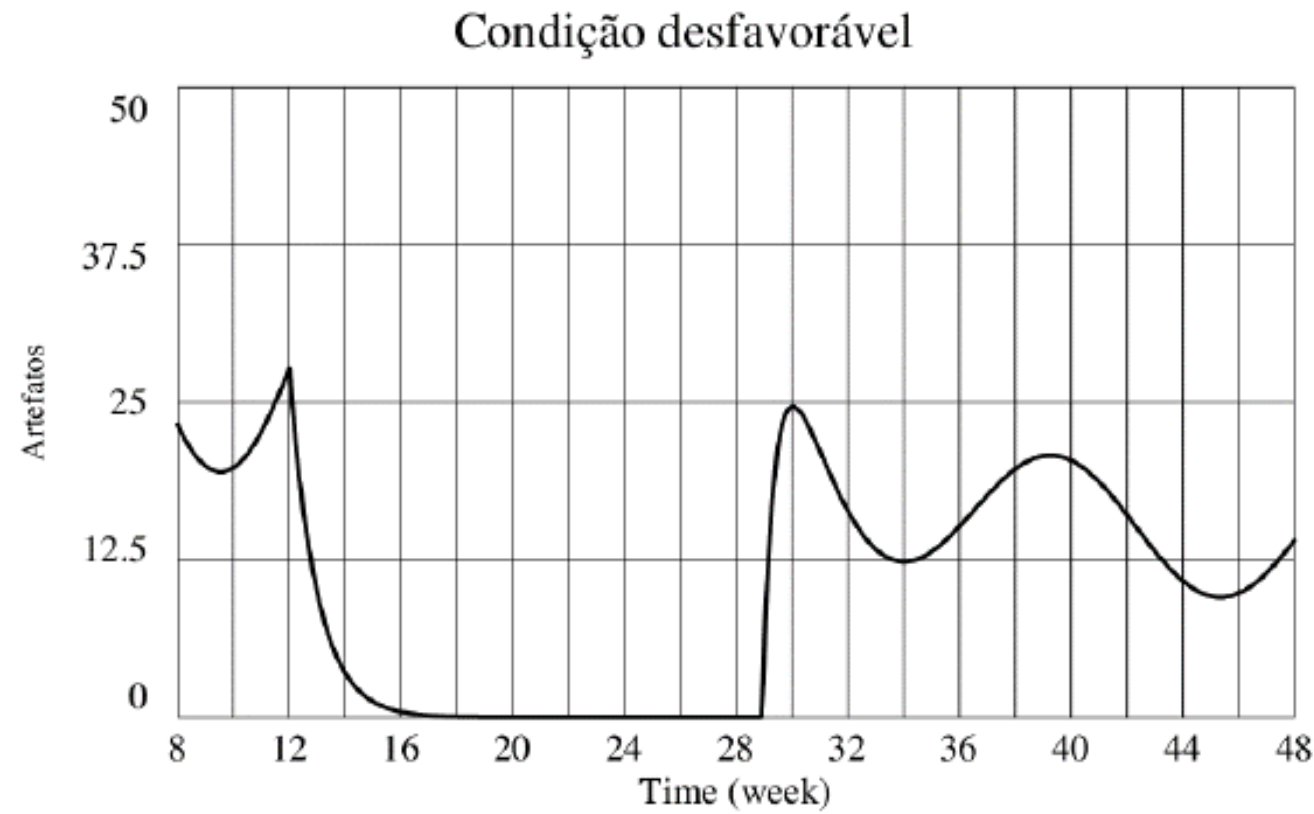

Trabalho em processo:Sim_cond_desfav_inc_TC

Fonte: o autor.

Com a consideração de um intervalo de tempo fixo para a demanda por serviços após a obtenção do novo patamar de qualidade referente ao bem tangível a redução do tempo de ciclo não afeta o subsistema de prestação. Porém, a seguir a condição desfavorável ao sistema é conduzida com impacto no subsistema de prestação.

\subsubsection{CONDIÇÃO DESFAVORÁVEL (SERVIÇO)}

Visto o comportamento do sistema para a condição abordada anteriormente a simulação agora é conduzida com a indução do acréscimo na expectativa de qualidade aplicada à expectativa referente aos aspectos do serviço. A expectativa quanto ao bem tangível é configurada novamente para a condição favorável enquanto o acréscimo de 30\% na expectativa é aplicado ao serviço também no instante 12 (semanas).

Salienta-se, no entanto, que o aprimoramento dos procedimentos que orientam a realização das atividades e o desenvolvimento de competências dos profissionais pode ocorrer mesmo ao longo da prestação. Contudo, a defasagem de tempo considerada frente ao incremento da expectativa do consumidor pode ser atribuída à adequação dos aspectos tangíveis dos serviços, assim como questões referentes à infraestrutura e aos recursos demandados, ou quaisquer outros que requeiram tal adequação. Mesmo questões de prazos de conclusão das atividades podem impedir a adesão do 
consumidor e também demandar um determinado tempo para que sejam estabelecidas novas condições de prestação dos serviços de maneira mais eficiente e tão eficaz quanto. Para tal consideração a Figura 39 expõe a evolução da correção dessas questões salientadas (em relação à percepção da qualidade sob a avaliação do consumidor) resultante da atuação do ciclo "controle de qualidade do serviço".

Figura 39 - Condição desfavorável (serviço): “expectativa e percepção da qualidade”

\section{Condição desfavorável}

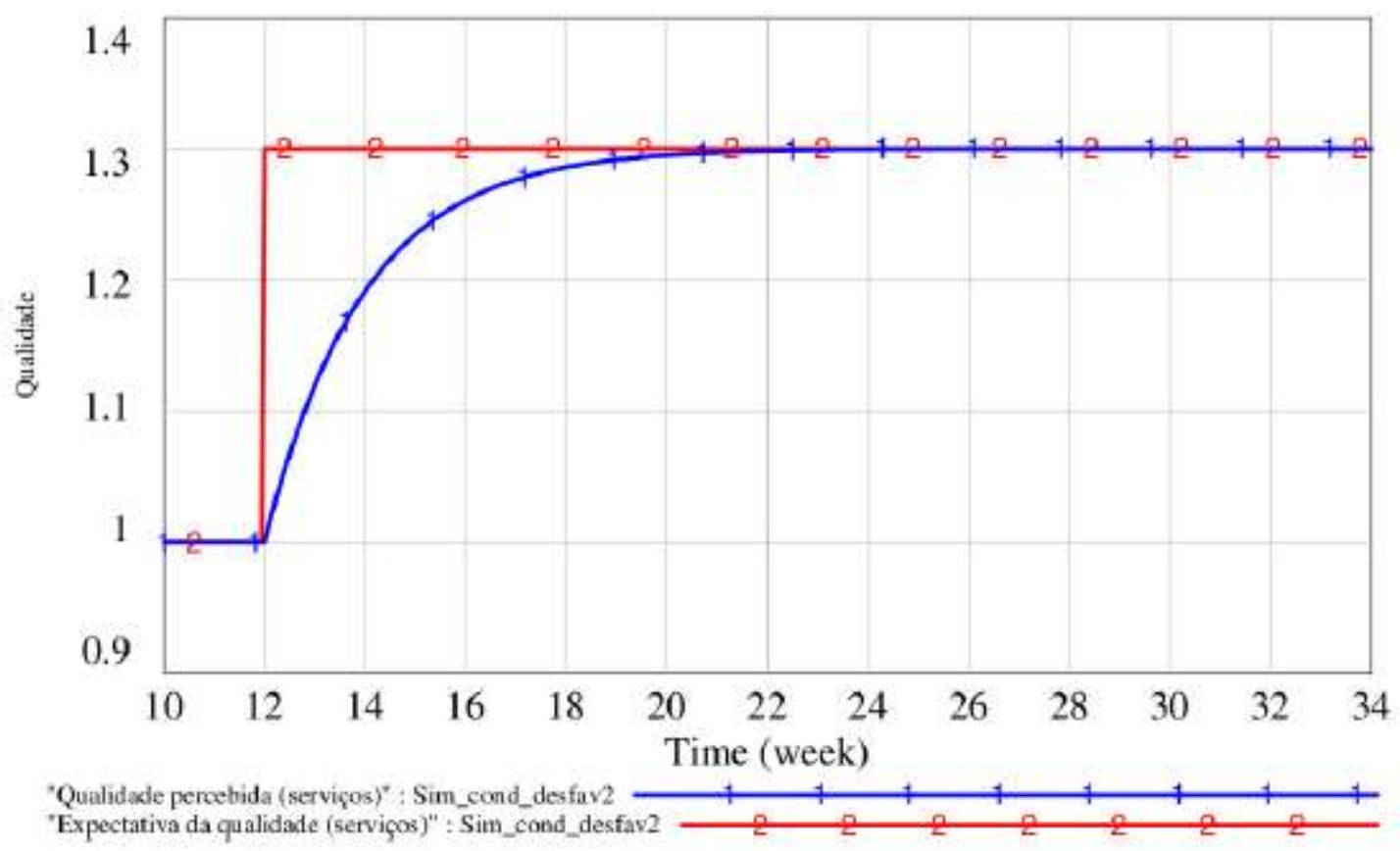

Fonte: o autor.

Da mesma maneira que para os bens tangíveis, em função da estrutura idêntica do ciclo de controle da qualidade dos serviços, a diferença entre a expectativa e a percepção leva à atuação do ciclo de controle. No entanto, o tempo de correção para o subsistema de prestação é configurado em um valor menor em comparação ao subsistema de produção. Essa configuração considera o tempo para a correção da qualidade percebida referente aos aspectos de qualidade relacionados ao serviço menor em relação à correção da qualidade do bem tangível. Frente à flexibilidade de soluções possíveis ao PSS supõe-se que estas constantes temporais podem apresentar uma considerável variação. Mas, novamente salienta-se que a análise é dada em termos de comportamento.

Como a satisfação da qualidade referente aos aspectos do serviço atua na restrição da "taxa de adesão" a demanda por artefatos, neste modelo, não é alterada. Como é mostrado na Figura 40 o 
subsistema de produção continua atuando para manter o nível de estoques conforme o planejado e compensando as perdas pelo consumo da mesma maneira que para a condição favorável.

Figura 40 - Condição desfavorável (serviço): "artefatos disponíveis"

\section{Condição desfavorável}

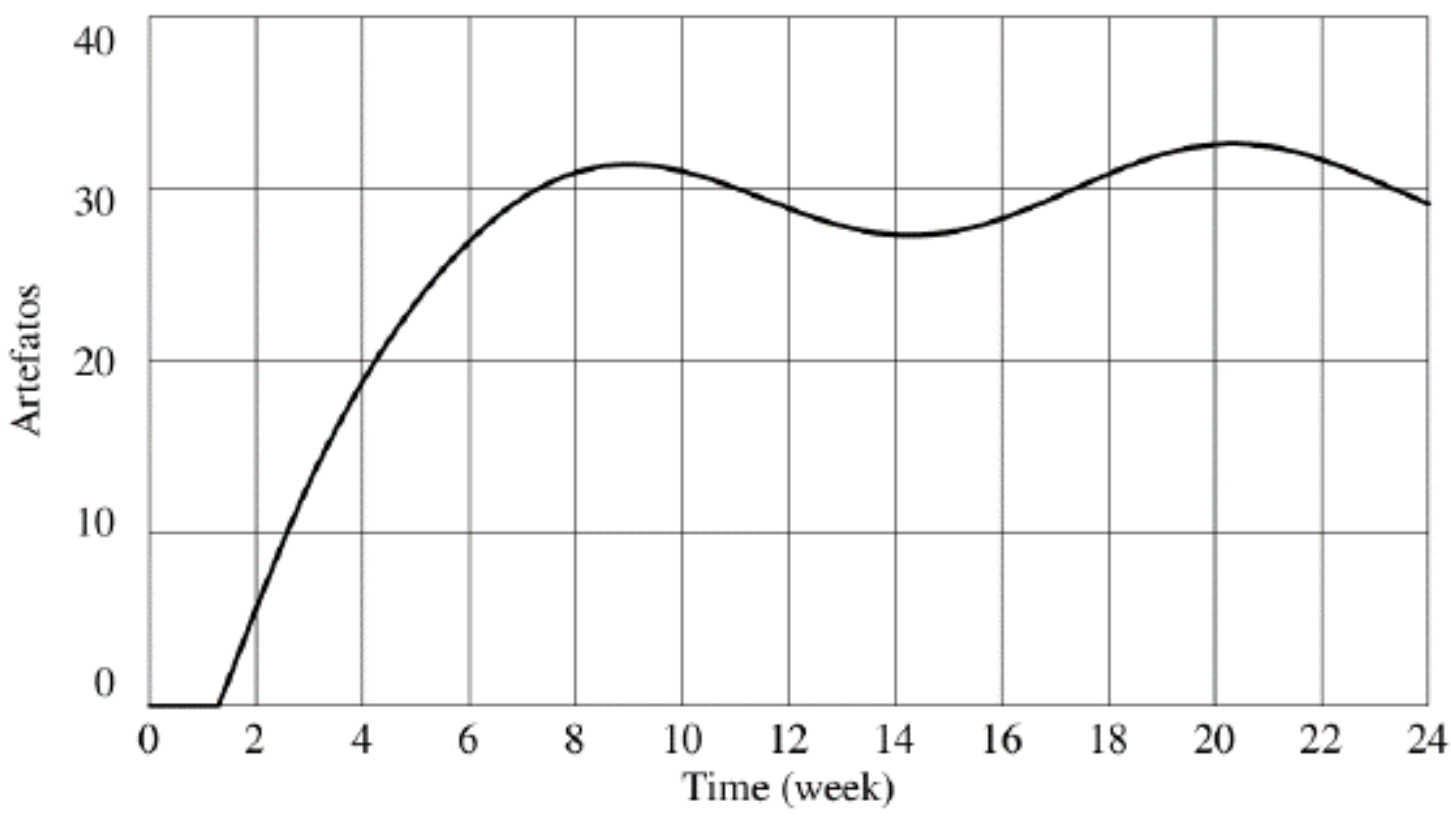

Artefatos disponíveis: Sim_cond_desfav2

Fonte: o autor.

Contudo, com os consumidores já ingressados no sistema pela obtenção do bem tangível e pela restrição da taxa de adesão ao subsistema de prestação pela condição da percepção da qualidade temse a geração de um acúmulo de consumidores aguardando o processamento. $O$ aumento deste acúmulo se dá pela taxa de flutuação da demanda de referência. A Figura 41 evidencia a situação de geração de consumidores em espera. Mas, como também é mostrado nessa figura esse excesso de consumidores em espera é consumido pelo subsistema de prestação assim que o novo patamar de percepção da qualidade é alcançado. O consumo desse estoque de consumidores em espera, conforme a estrutura do sistema e a não consideração restrições para um nível máximo de taxa de adesão (na qual a infraestrutura e os recursos do sistema exercem influência) é realizado rapidamente com um grande aumento da taxa de adesão. 
Figura 41 - Condição desfavorável: "consumidores em espera”

\section{Condição desfavorável}

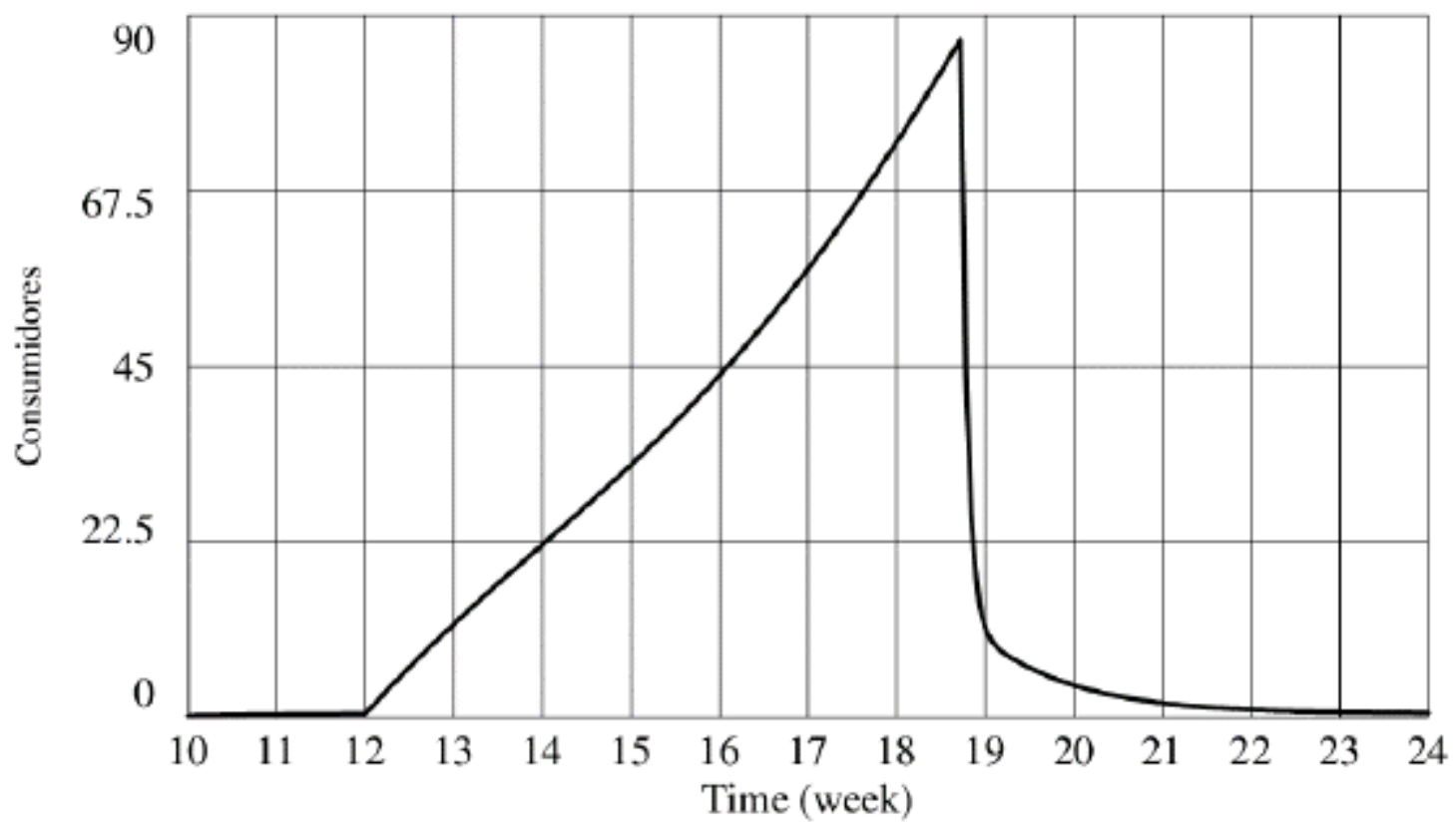

Consumidores em espera : Sim_cond_desfav2

Fonte: o autor.

A quantidade de consumidores em processo após a obtenção da qualidade referente aos serviços tem um pico por considerar o processamento dos consumidores em espera. Em casos em que a taxa de processamento é relativamente elevada (em contraste com o subsistema de produção) o sistema consegue novamente acompanhar a demanda por serviços passado um curto horizonte de tempo. Essa situação é evidenciada na Figura 42.

Figura 42 - Condição desfavorável (serviço): "consumidores em processo"

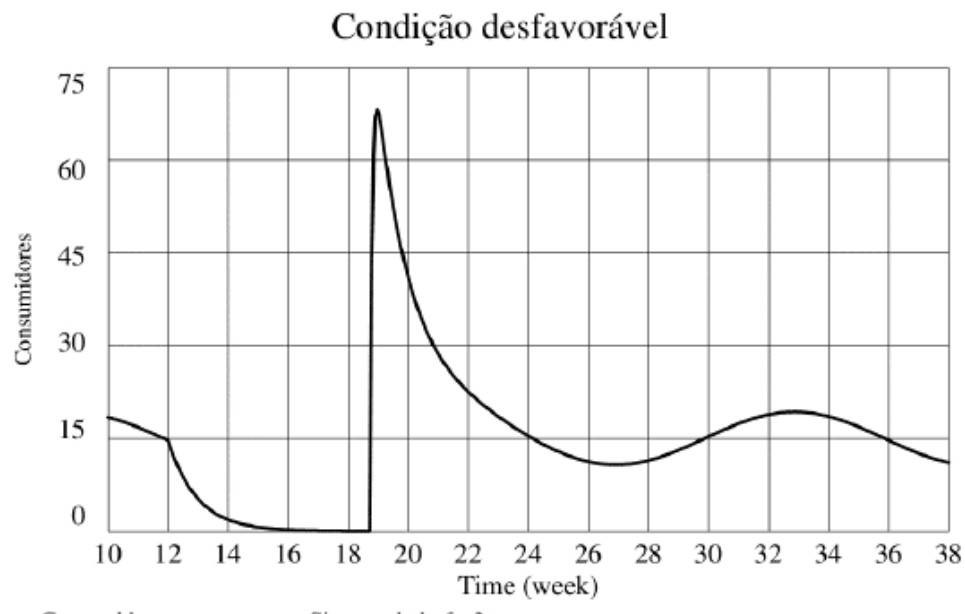

Consumidores em processo : Sim_cond_desfav2

Fonte: o autor. 
Assim, havendo a possibilidade de acúmulo de consumidores em espera até a obtenção do estado de satisfação e a possibilidade de processamento desses, o sistema é capaz de retomar o comportamento. Como mostra a Figura 43 o montante de pacotes de valor entregues apresenta uma breve redução do crescimento e em seguida esse crescimento cessa. Obtida a condição de igualdade entre a expectativa e a percepção da qualidade referente aos aspectos dos serviços o crescimento de consumidores processados passa novamente a apresentar crescimento e em uma taxa de processamento superior de maneira a compensar o montante do período em que não houve crescimento. Com o sistema novamente acompanhando a flutuação da demanda de referência o comportamento da quantidade de pacotes de valor entregues se apresenta como na condição favorável, possibilitada pela atuação dos ciclos de controle, entre eles o ciclo responsável pelo controle da qualidade dos aspectos relacionados aos serviços.

Figura 43 - Condição desfavorável (serviço): "consumidores processados"

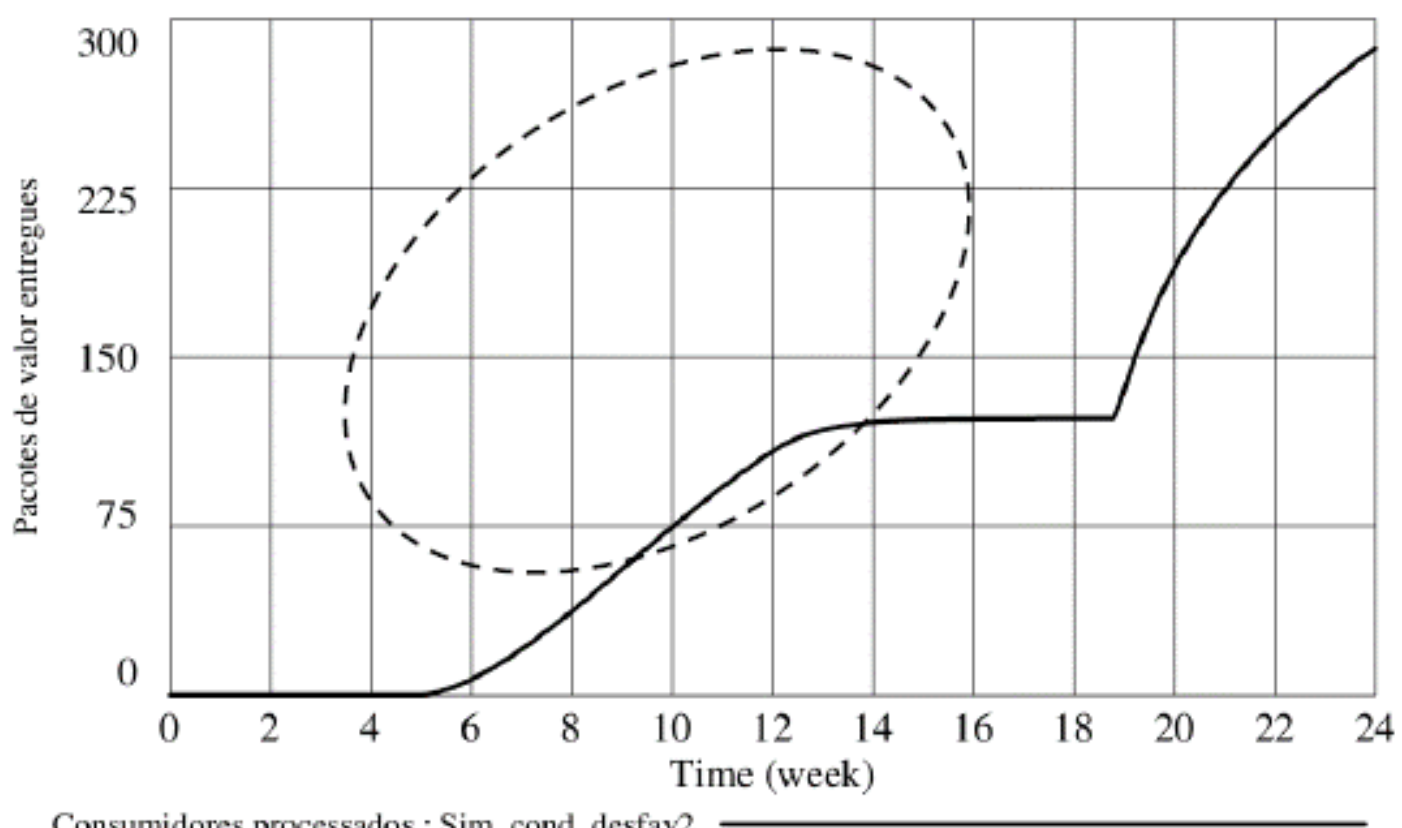

Fonte: o autor.

Dentro dessa condição desfavorável, porém, uma situação crítica ainda pode ser apontada para sistemas caracterizados com uma taxa de saída dos consumidores em espera. Com a ação das "perdas em espera" por consequência o montante de consumidores em espera tenderá a ser menor como mostra a Figura 44 na qual a curva (1) representa a situação sem a ação de perdas e a curva (2) representa a tendência de geração do montante em espera para um sistema caracterizado por um tempo médio de saída de 0,5 (semanas). 
Conforme salientado neste caso os consumidores perdidos em espera não são processados pelo sistema com a retomada da atuação do controle da prestação. A Figura 45 evidencia essa situação com a sobreposição da condição (1) sem perdas e (2) com perdas em espera.

Figura 44 - Condição desfavorável (serviço): ação das "perdas por espera"

Condição desfavorável

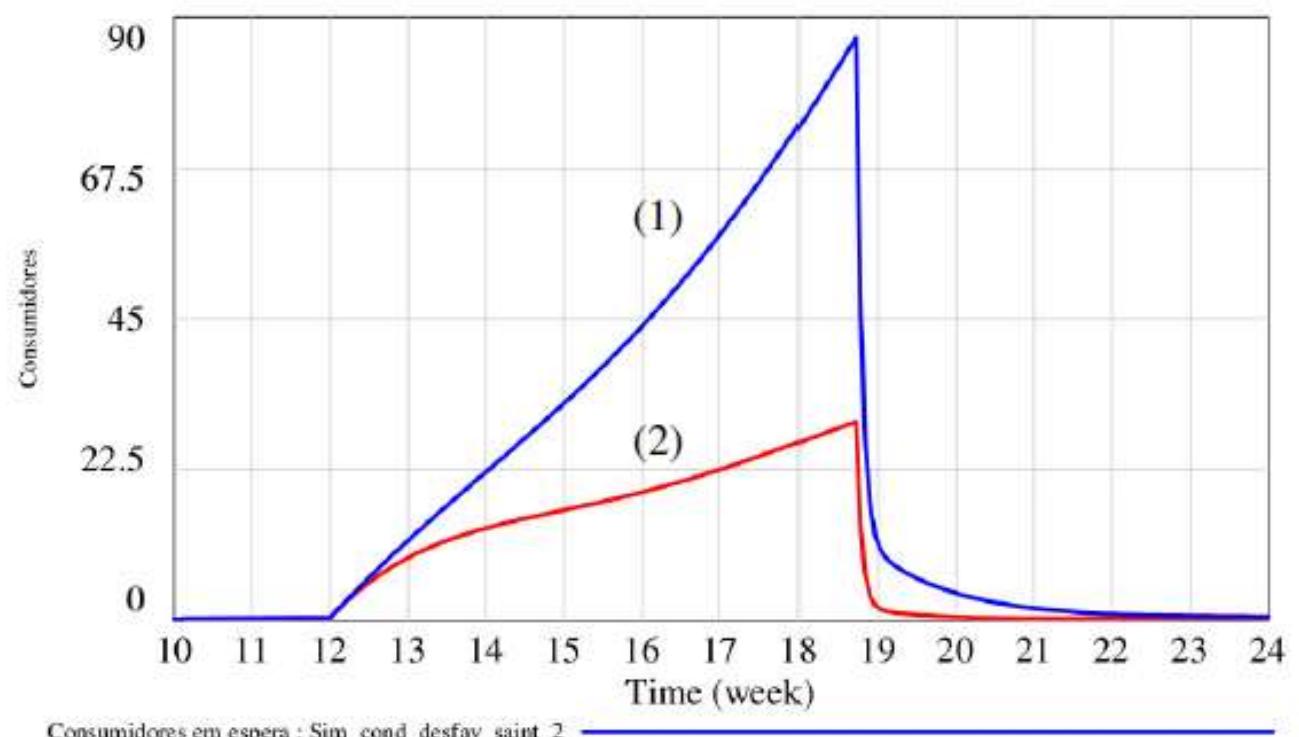

Fonte: o autor.

Figura 45 - Condição desfavorável (serviço): "consumidores processados" com e sem perdas

\section{Condição desfavorável}

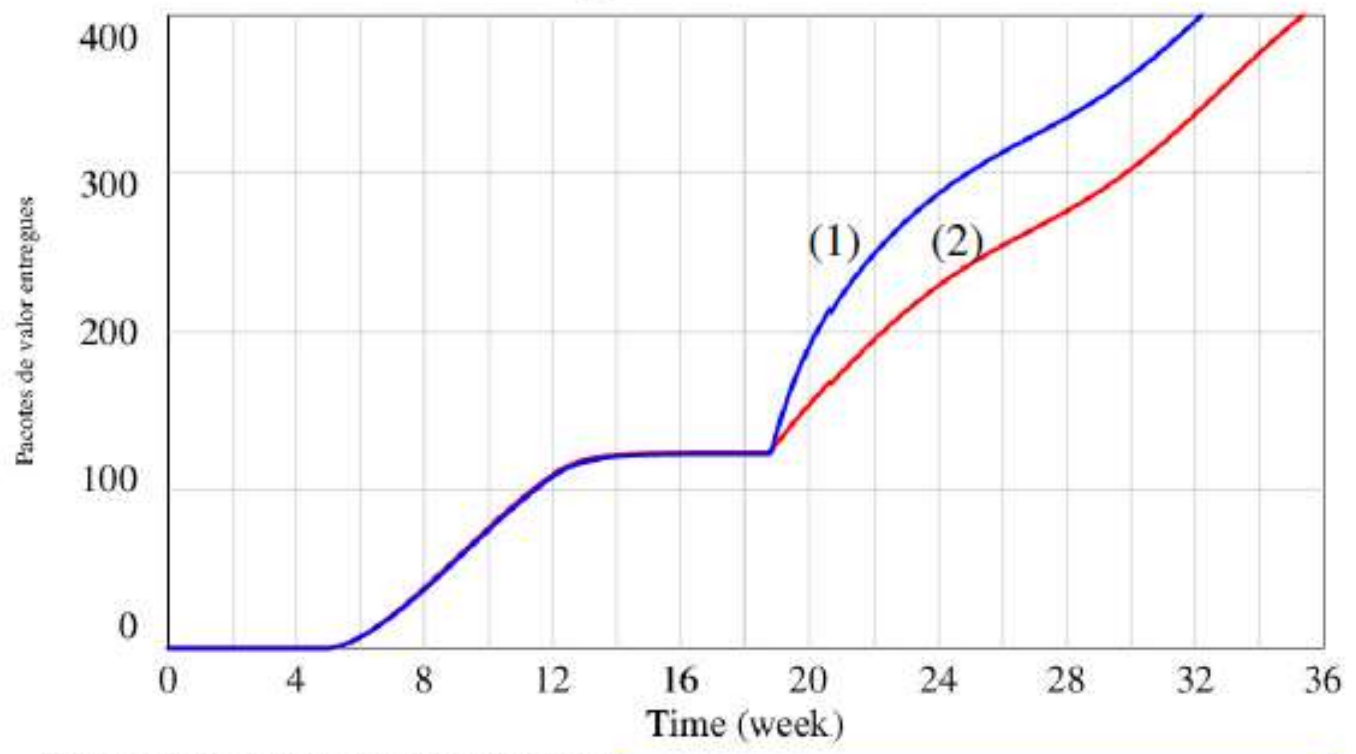

Consumidores processados : Sim_cond_desfav_saint_2

"Consamidores processiados ${ }^{* *}$ : Sim_cond_desfav_saint_2

Fonte: o autor. 
Outra situação crítica explorada nessa simulação está em sistemas caracterizados por uma taxa de desistência de consumidores. Diferentemente da ação observada para as perdas de consumidores em espera, que ocorrem pelas condições de atuação do subsistema de prestação, as "perdas por desistência" ocorrem ao longo de todo o horizonte de simulação.

Como podem ser observadas na Figura 46, havendo desistência, essas ocorrem mesmo antes da ação de indução das condições desfavoráveis ao serviço e permanecem mesmo após o ciclo de realimentação referente à qualidade dos serviços conduzirem a percepção à igualdade com a expectativa de valor. Para a geração deste cenário a curva (1) corresponde ao comportamento do sistema sem a ação de desistência dos consumidores. Já a curva (2) corresponde ao comportamento no qual a variável "tempo médio de desistência" é configurada para o valor de 0,5 (semanas).

Figura 46 - Condição desfavorável (serviço): "consumidores processados" com e sem desistência

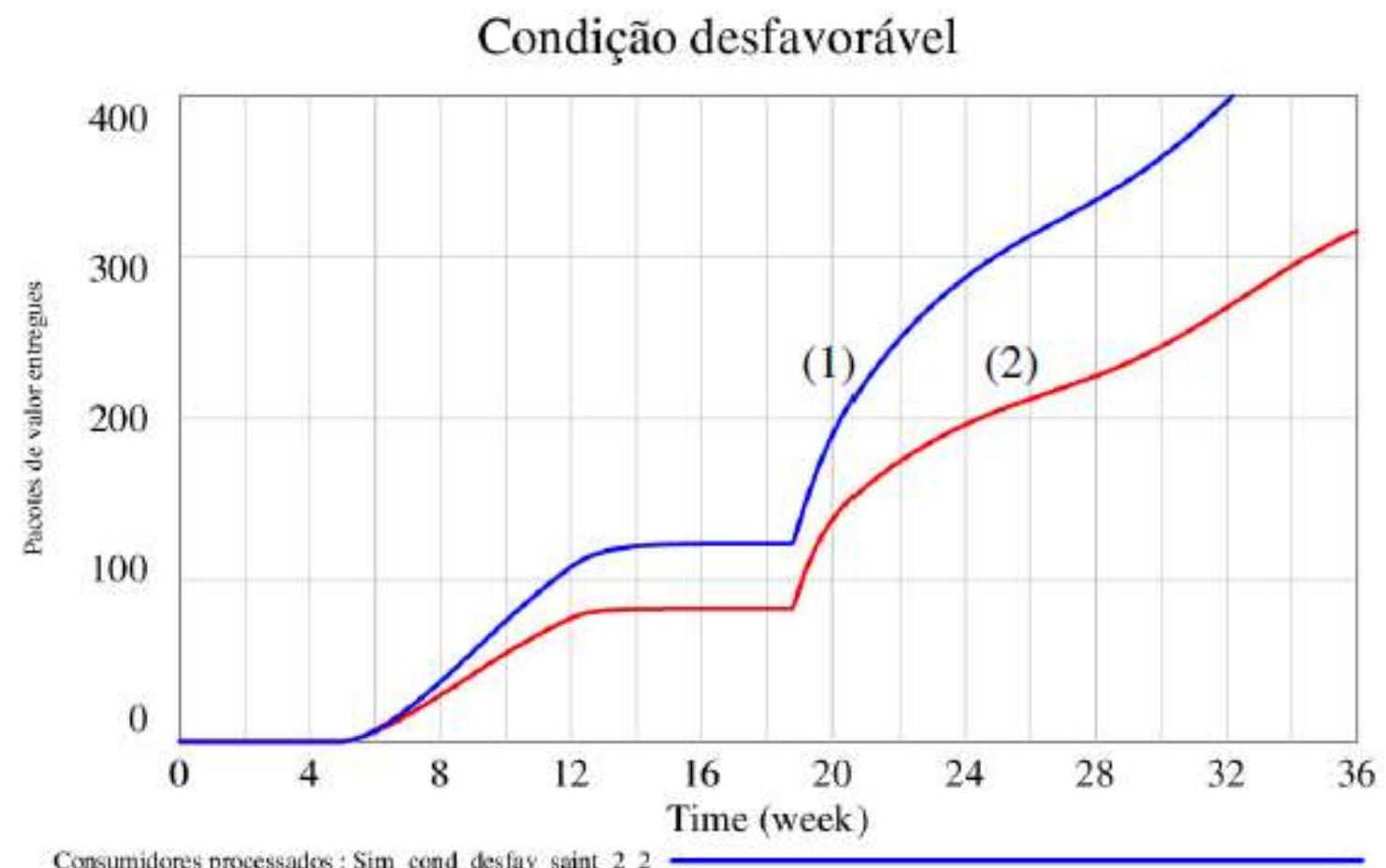

Consumidores processados: Sim cond desfav saint 22

"Consumidores processiados" ; Sim_cond_desfay_saint_2_2

Fonte: o autor.

Complementando essa análise outro cenário ainda é proposto. Conforme também salientado no diagrama conceitual além de haver a possibilidade da atuação no produto contribuir com a facilidade de obtenção do valor agregando soluções de projeto voltadas a reduzir o tempo de fabricação; também se considera que em certas ocasiões (diretamente relacionadas à natureza dos serviços agregados) essa atuação poderia contribuir com a taxa de processamento dos consumidores. Essa 
consideração, por sua vez, insere a possibilidade de ênfase às atividades fins do módulo de serviço agregado quando ocorrem com a interação com o bem tangível. Isto pode ser viabilizado com a aplicação das diretrizes de desenvolvimento do produto conforme as abordagens específicas DFX correlacionadas ao serviço técnico específico. De modo geral, especificações de projeto desenvolvidas em conjunto entre fabricante e prestador, e como tal, originadas de requisitos específicos para o módulo de serviço, podem contribuir com o desempenho da entrega de valor.

Portanto, este cenário considera um incremento na expectativa referente ao serviço restringindo o ingresso dos consumidores no módulo de serviço. O tempo para correção da qualidade atribuída aos aspectos de serviço foi configurado para cinco semanas dando ênfase a formação de consumidores em espera. Nesse cenário se considera que a correção é advinda da atuação no artefato físico, contudo, não foi considerada uma parada na produção visto que

(i) o incremento da expectativa é considerada ao que tange os serviços e (ii) as atividades de desenvolvimento podem ocorrer em paralelo com a atividade produtiva. Então, a obtenção da percepção da qualidade satisfeita é acompanhada de uma redução do tempo de processamento. Essa constante é configurada inicialmente para duas semanas, passando para uma semana com a intervenção no artefato. O tempo de correção dos consumidores em espera foi configurado para 0,6 semanas e o tempo de correção dos consumidores em processo para uma semana. Ressalta-se que para este cenário não foram consideradas perdas por espera. Com a simulação efetuada a Figura 47 expõe o comportamento gráfico apresentado pela saída do sistema, sendo a curva (1) considerando a intervenção no tempo de processamento pela atuação no bem tangível e a curva (2) sem essa atuação. Percebe-se que o pequeno aumento apresentado no cenário em que a intervenção no produto reduz o tempo de processamento se deve unicamente ao processamento em menor tempo do montante dos consumidores em espera. O subsistema de prestação processa a mesma quantidade de consumidores em um tempo reduzido, entretanto, pelas demais condições de simulação, esse é o único reflexo no sistema que pôde ser evidenciado. 
Figura 47 - Condição desfavorável (serviço): Intervenção TP

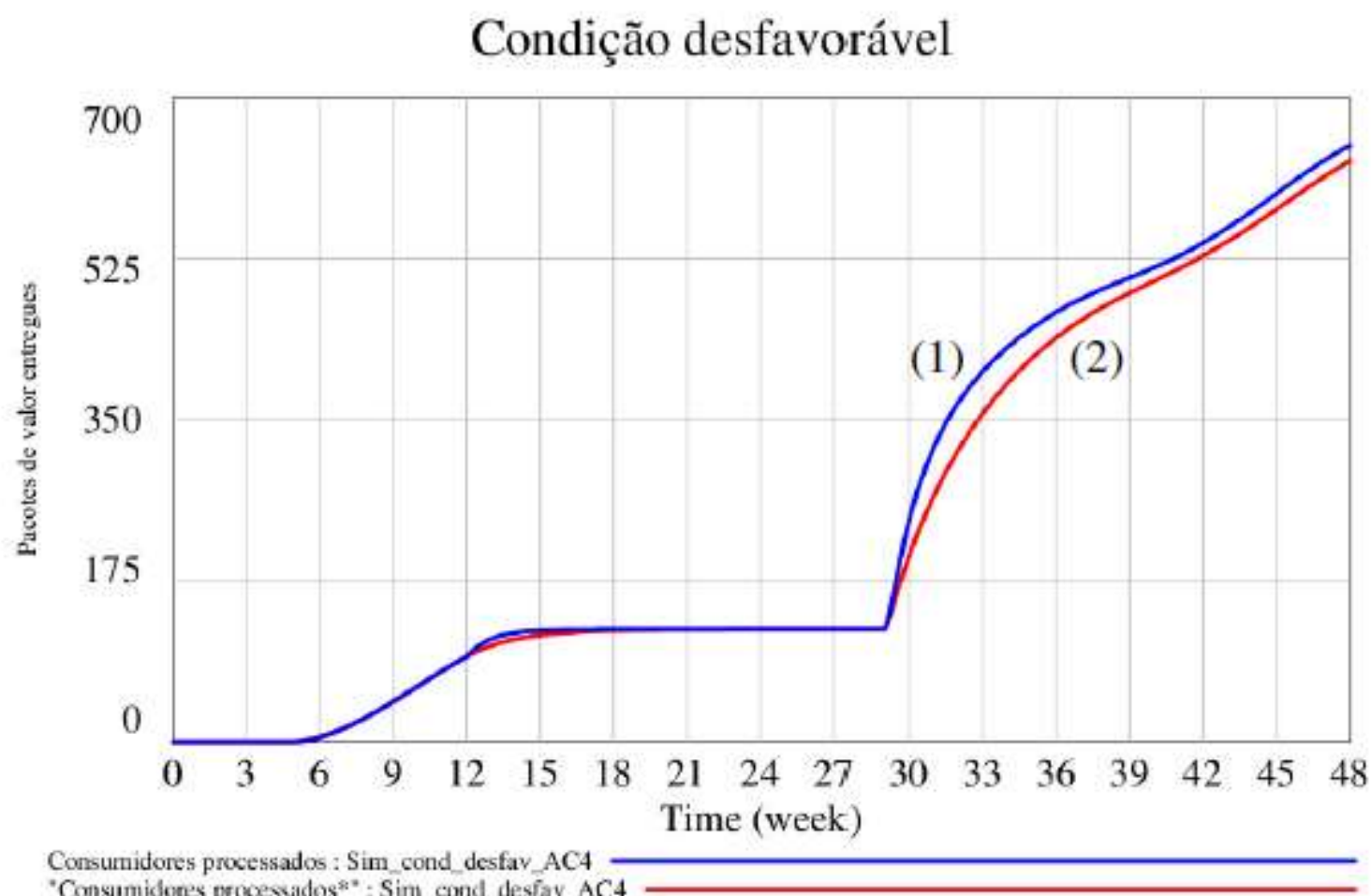

Fonte: o autor.

Com isso, os dados necessários para a análise interpretativa foram gerados. A seção seguinte, de suma importância, efetiva essa análise para que possam ser propostas as soluções para as condições indesejáveis prospectadas.

\subsection{ANÁLISE DO COMPORTAMENTO}

Com o modelo do sistema amparado pelo conjunto de testes empregados conferindo robustez e confiança para a simulação de comportamento, e pela própria condução da simulação, certos aspectos do comportamento do sistema são salientados e analisados. Nessa análise são abordadas questões relativas ao contexto descrito e às demais considerações da abordagem que culminam em tal comportamento. Além disto, também são salientadas contribuições identificadas ao longo da abordagem, e de bibliografias diversas, úteis a este exame.

O primeiro aspecto destacado se refere à condição de satisfação do valor. Conforme sugere o contexto descrito e os cenários projetados nessa análise a percepção de valor do consumidor pode gerar diferentes reflexos e em diferentes partes do sistema. Como valor sendo entregue ao longo da realização do ciclo de vida, esse valor pode estar sujeito a sucessivos julgamentos pela percepção do grupo de interesse. 
A simulação do comportamento segundo essa análise ilustra o impacto do não atendimento do fator "qualidade" para o bem tangível e para um módulo de serviço. O modelo proposto considera que a estrutura sistêmica de controle da qualidade é capaz de conduzir o sistema novamente a uma dinâmica favorável em um intervalo constante de tempo, bem como considera que alguns reflexos no sistema são reversíveis. Essa e outras considerações podem não condizer com um sistema real como devidamente ressaltado. Além disto, essa representação do sistema certamente não considera muitos outros fatores que podem atenuar as restrições impostas na simulação como, por exemplo, eventuais renegociações de prazos. Contudo, o impacto evidenciado pela simulação ilustra que a condição desfavorável relacionada à satisfação de valor compromete o desempenho do sistema. Fundamentalmente, para este aspecto do comportamento, essa análise sugere que muitas condicionantes referentes à satisfação do valor podem estar, mesmo que de diferentes maneiras, envolvidas para a realização do ciclo de vida no PSS. Nesse sentido, frente a essa condicionante do desempenho dinâmico se destaca a importância do "fortalecimento da integração de ações voltadas à satisfação do consumidor".

Conforme a condução da simulação, o comportamento esperado para o sistema resulta da condição favorável, ou seja, da condição de atendimento dos requisitos e da qualidade desses requisitos. Para tal essa análise evidenciou da literatura especializada abordagens a ferramentas voltadas para a mensuração da satisfação do consumidor no contexto do PSS como mostram os artigos de Kimita, Shimomura e Arai (2009) e Yoon, Kim e Rhee (2012) que integram o portfólio. Essas ferramentas voltadas ao PSS se enquadram nas fases iniciais da metodologia de desenvolvimento apresentada como exemplo na fundamentação geral (a metodologia MePSS). Sua aplicação na atividade de desenvolvimento pode orientar uma abordagem adequada ao produto e viabilizar a obtenção dos requisitos necessários à satisfação do consumidor na dinâmica do ciclo de vida. Essa análise também ressalta, em convergência ao exposto na descrição do contexto, que dentre as funções básicas apontadas aos serviços técnicos por Aurich, Fuchs e Wagenknecht (2006) está a função de coleta de informações de uso do artefato físico (como experiências e sugestões) junto ao consumidor que pode ser realizada pela equipe de campo de serviços. Essas informações direcionadas ao objetivo de atendimento dos requisitos exigidos ao produto em termos de assegurar o nível de benefícios esperados em vista das ofertas complementares (também uma função básica atribuída aos serviços técnicos) complementam o emprego das ferramentas mencionadas a princípio. Essas funções são direcionadas à elucidação e atuação nos requisitos e seus respectivos níveis de qualidade ao longo da realização do sistema. Ainda em complemento a estes dois aspectos mencionados (a consideração dos 
requisitos e sua qualidade no desenvolvimento e seu acompanhamento por informações específicas na etapa de implantação do sistema), nessa análise também se identificou uma linha de trabalhos voltados ao aspecto dinâmico de aporte ao ciclo de vida e, portanto em convergência com esta abordagem26. Destes estudos se salienta a utilização de bases de dados com arquitetura voltada em específico ao ciclo de vida do PSS. Essas bases objetivam principalmente a gestão dinâmica dos requisitos referentes ao produto, contribuindo para a correta atuação nesse, tanto em termos de conteúdo a ser implementado quanto na questão do momento de implantação.

Entretanto, a percepção do valor é apenas uma das condicionantes no contexto descrito para o sistema. Além de atribuir a qualidade exigida ao bem tangível (e aos aspectos do serviço), este bem também precisa estar disponível para a utilização no contexto do sistema. O acesso ao artefato físico em uma linguagem conveniente para a dinâmica abordada é colocado pela condição de "facilidade de obtenção do valor". Na construção do modelo, em função dos subsistemas abordados, não foram agregados fatores exógenos de influência na facilidade de obtenção de valor. Dessa maneira, nesse contexto a única restrição considerada para tal condicionante consiste na disponibilidade do valor provida pelo subsistema de produção, ou seja, a facilidade de obtenção do valor no contexto descrito resulta unicamente das ações de controle e restrições operacionais dos processos produtivos. Mas, frente ao conhecimento construído ao longo do desenvolvimento dessa análise, essa análise salienta que outros fatores são passíveis de consideração no que se refere à condição de obtenção do valor. A disponibilidade e capacidade dos sistemas de transporte, bem como a localização dos pontos de distribuição, podem estar envolvidas para tal obtenção. Nesse sentido, como mostrado por Lelah, Mathieux e Brissaud (2011), a logística exigida para a obtenção do valor em determinados sistemas pode ainda requerer uma infraestrutura específica. Isto também se acentua quando no sistema estão envolvidas diferentes configurações do artefato e seus serviços associados para o atendimento de diferentes ciclos de vida no PSS. A modularização e as estratégias de plataforma, como vistos na fundamentação da análise, propiciam o atendimento a diferentes ciclos de vida. Nesse sentido, como argumentam Evans, Partidário e Lambert (2007), o fabricante integra um arranjo específico no PSScom demandas específicas à produção. Tendo em vista um desempenho favorável referente à condição de obtenção do valor na dinâmica do sistema descrito essa análise sugere também que a importância do "fortalecimento da integração de ações direcionadas à facilidade de obtenção do valor" não pode ser descartada. 
As ações salientadas para tal, no âmbito do desenvolvimento do produto, ressaltam a importância da exploração das necessidades e oportunidades referentes à facilidade de obtenção do valor no sistema, além de ações voltadas à sua viabilização no que se refere ao produto. A articulação de informações também com a rede responsável pela logística pode identificar tais necessidades oportunidade a serem exploradas e conduzir o projeto a uma abordagem ainda mais holística no âmbito do PSS. Um exemplo de tal abordagem pode ser obtido com Olsson e Larsson (2009) que investigam a adição de valor na perspectiva do PSS com o desenvolvimento integrado do produto focando o conjunto de artefato e embalagem. A integração desses elementos é abordada como um subsistema tendo influência no desempenho do sistema macro27. Nesse sentido, os esforços no desenvolvimento do produto podem prover a eficácia requerida ao transporte e distribuição em determinados arranjos caracterizados para o Sistema Produto-Serviço. Assim os domínios da atividade de desenvolvimento seriam estendidos para além das considerações de funcionalidade e de qualidade dos atributos do produto. Contudo, para outros sistemas (como nos casos fundamentados de produtos e serviços modulares que atribuem uma maior complexidade operacional ao sistema produtivo) essa análise também resguarda a importância das práticas e princípios de desenvolvimento voltados ao próprio sistema produtivo. Essas práticas e princípios são comentados adiante em relação a condicionante do desempenho afetada por estas diretamente.

Antes, porém, também se salienta que tal como para o bem tangível os serviços responsáveis pela agregação do valor podem estar associados a diversos canais de distribuição. A condução dos parâmetros de estados do consumidor para a condição de satisfação, conforme o fundamentado na associação entre os elementos de bem tangível e serviço, também tem influência dos canais de serviços (KIMITA; SHIMOMURA; ARAI, 2009). O termo "facilidade de consumo do valor" insere essa condição para o contexto dinâmico e pode ter influência dos canais mencionados e ainda outros, dependendo da configuração específica do sistema. A extensão da rede de agregação de valor por meio dos serviços planejada na configuração do ciclo de vida e os tipos de serviços envolvidos no sistema podem ser determinantes para a quantidade e características desses canais. Esses podem corresponder a canais físicos necessários para a prestação dos serviços, mas também como salientam Lovelock,Wirtz e Hemzo (2011) o tipo de conteúdo do serviço (como desempenho, experiências e informações diversas) pode requer também canais eletrônicos de distribuição. Esses seriam fatores exógenos ao contexto descrito que, pela condução da modelagem, não foram inseridos por não pertencerem diretamente aos subsistemas abordados. Assim, essa condicionante é influenciada unicamente pela restrição operacional relativa ao tempo necessário ao processamento dos 
consumidores (o tempo de processamento). Essa restrição será abordada logo em seguida no referente aos fatores operacionais. Mas, sobretudo essa análise salienta para o contexto descrito que também não pode ser negligenciada a importância do "fortalecimento da integração de ações voltadas à facilidade de consumo do valor".

Nessa linha de argumentação e pelo aporte do fundamentado a facilidade de consumo do valor pode ser atingida por parâmetros funcionais relativos aos canais de distribuição dos serviços. A facilidade de consumo do valor, se esta facilidade constituir um fator decisivo para a permanência no sistema (e não gerando uma situação desfavorável de desistência de consumidores evidenciada pela simulação) pode influenciar fortemente o desempenho do sistema. Assim, a consideração de parâmetros funcionais originados das necessidades ou oportunidades relacionadas aos canais de distribuição dos serviços pode ser convertida em requisitos funcionais relacionados ao produto. Esses, por suas vezes, conduzem para soluções de projeto do produto voltadas às funções dos canais de serviços. Como aporte para tal na atividade de desenvolvimento do produto, a exemplo da abordagem à condicionante anterior, também se ressalta a importância da exploração das necessidades e oportunidades referentes a estes canais de serviço. Além disto, ações voltadas à sua viabilização no que se refere ao produto agregando uma abordagem mais holística no sistema podem ser significativas para o desempenho do sistema.

Por fim, essa análise aborda a condição de desempenho dinâmico referente aos fatores operacionais e de controle. Esses são abordados em conjunto pela (i) dependência que existente entre esses fatores (já que determinados processos de controle podem impor restrições operacionais e, em contra partida, algumas restrições podem exigir determinados processos ou métodos de controle) e por (ii) ambos serem atribuídos às influências internas ao sistema. Pelo uso das ferramentas da Dinâmica de Sistemas a consideração dos fatores operacionais recai nas restrições responsáveis pela defasagem de tempo para a adequação da qualidade do produto e do serviço e para a ocorrência da demanda por serviços. Além destas ainda são englobadas as restrições, também em termos temporais, dos sistemas de produção e prestação para correção do trabalho em processo, correção do estoque de artefatos disponíveis, correção dos consumidores em espera e dos consumidores em processo e, principalmente o tempo de ciclo e o tempo de processamento. A descrição do contexto (diagrama de causalidade) justifica as defasagens de tempo consideradas. Em complemento, a própria exposição do comportamento observado (nesta simulação) ressalta outras defasagens que foram desconsideradas em confronto com as características do fluxo principal do sistema, suprimindo também aspectos de 
controle na estrutura do modelo. Essa estrutura descreve os próprios processos de controle em termos dinâmicos adotados para viabilizar a simulação. Nesse sentido, a modelagem da estrutura de decisão para o subsistema de produção teve seu aporte na literatura, com o exposto por Sterman (2000), bem como o estabelecimento das relações dinâmicas associadas à percepção do consumidor como referência para a modelagem do subsistema de consumo. Contudo, para o estabelecimento da estrutura referente ao subsistema de prestação não foram encontradas abordagens correlatas, sendo que, sua construção foi orientada por considerações específicas. Sendo assim, os comportamentos descritos graficamente referentes à atuação dos subsistemas nos cenários projetados e, portanto, as próprias informações de referência para essa análise, derivam das considerações relativas às restrições operacionais e estruturas de controle. Os níveis dos indicadores apresentariam outras amplitudes e defasagens para restrições distintas às utilizadas, bem como, o próprio comportamento gráfico seria diferenciado tendo, o modelo, outra estrutura de decisão ou outra variação da demanda induzida. Não obstante, como salientado anteriormente nesta seção, outros fatores poderiam ser considerado com a expansão dos limites do sistema, o que também influenciaria no resultado obtido pela simulação.

Portanto, o exposto até então reafirma, com base nos princípios que orientaram a análise, a dependência do "fortalecimento da integração de ações voltadas à operacionalização e controle" para o desempenho "favorável" do PSS. Destacada essa dependência as ações no âmbito da atividade de desenvolvimento podem focar na exploração das restrições e possibilidades de atuação e seu impacto no sistema pelas estruturas de controle específicas. Para isso (no que se refere à exploração) tais considerações devem ser abordadas logo no processo de desenvolvimento do PSS e tem base no conhecimento dos envolvidos acerca desses aspectos para cada subsistema. Isso engloba as práticas e procedimentos relacionados à aplicação dos serviços, como também engloba as próprias restrições inerentes ao processo de confecção do artefato envolvido no sistema. A complexidade imposta ao sistema produtivo tanto no que se refere a sua operacionalização quanto ao seu controle (visto que diferentes demandas podem orientar as decisões do processo) pode ser maior em casos de produtos modulares. Já a atuação em tais restrições pode ser orientada pelas regras e princípios referentes às abordagens DFX. Essas abordagens dispostas na literatura especializada podem enfatizar certas etapas do ciclo de vida conferindo um melhor desempenho. Em virtude destas considerações, na simulação ainda foi testado o impacto da atuação nas restrições determinantes das defasagens referentes ao "tempo de ciclo" de fabricação dos artefatos e ao "tempo de processamento" dos consumidores por meio da atuação no produto. Com foco no sistema produtivo (atuando no tempo de ciclo) são 
aplicáveis as regras e princípios específicos referentes ao DFM, DFA, DFT (Design for Test)28 e possíveis outras orientações do DFX. Também, nessa perspectiva essa abordagem considera que a atuação no artefato por princípios como os referentes ao DFS e/ou DFO (Design for Operation), e mesmo possíveis abordagens distintas, também podem ser aplicáveis ao PSS e influenciar em seu desempenho. Considera-se, portanto, que essas abordagens podem inferir nas variáveis de processo reduzindo as restrições operacionais referentes ao processamento de matérias primas para originar os bens e o processamento de consumidores buscando o estado de satisfação. Contudo, não foram testados os impactos dessas abordagens separadamente, ou mesmo considerados todas as abordagens relacionadas ao DFX, visto que não constitui o objetivo da análise. Nos cenários projetados os reflexos apresentados no sistema da atuação tanto no tempo de ciclo quanto no tempo de processamento estão correlacionados à demanda induzida e às estruturas de controle que formam o modelo. Ou seja, o que pôde ser observada na simulação consiste na redução do fluxo nos subsistemas (de material em processo para o subsistema de produção e de consumidores para a prestação) para o atendimento das mesmas solicitações. Não se pode descartar, porém, que para outras condições, como outro padrão da demanda, tal atuação no produto conduza a diferentes impactos no desempenho. Caso, por exemplo, a expectativa do consumidor esteja relacionada ao tempo de processamento a ação no produto para este fim pode inclusive ser determinante para a aceitação e ingresso no sistema.

Em complemento ainda se ressalta que da mesma maneira que o observado para as demais condicionantes a exploração das restrições pode e deve ser conduzida ao longo da realização do sistema (como sugere os próprios princípios da Dinâmica de Sistemas). Tal como mencionado anteriormente sobre as funções básicas dos serviços técnicos, no que tange esta condicionante se reafirma a utilidade da função de coleta de informações também para a operacionalização e controle. Essas informações direcionadas a questões de utilidade e condições de funcionalidade do artefato podem elucidar restrições ou identificar oportunidades de aplicação das abordagens DFX no processo de desenvolvimento para que a atuação no produto aperfeiçoe o seu desempenho ou complemente a sua função (expandindo ou aperfeiçoando, assim, o conjunto de benefícios oferecidos). Dentro das funções básicas dos serviços técnicos isso condiz ao "suporte funcional" sendo possível pela característica de realização dos serviços técnicos junto ao consumidor e ao bem tangível.

Essas são as considerações e observações que constituem a análise dos dados obtidos pela análise evidenciados nos cenários projetados pelo processo de simulação aplicado ao modelo. Grande parte do exposto não é inédito na literatura, porém abordado para outros fins e sobre outras perspectivas 
e estrutura. Essa análise explicita muitas convergências aos estudos que integraram o portfólio construído e que estabelecem os fundamentos desse estudo. Mas, principalmente essa análise organiza e trata as informações de maneira específica e, portanto, expõe uma perspectiva e uma análise singular. Outros pontos de vista poderiam prover uma diferente condução dessa análise, porém esta linha de argumentos é definida em convergência ao abordado nesta dissertação. Mas, o salientado nessa análise considera principalmente meios que potencialmente contribuiriam com a redução de fatores relacionados à geração de esperas (que, por sua vez, pode culminar na saída de consumidores) e a possível desistência de consumidores em processo; ambas as situações críticas apontadas no processo de simulação. Dessa maneira o teor desta análise é tomado como base para a proposição dos resultados.

\subsection{DIRETRIZES E RECOMENDAÇÕES}

As diretrizes são redigidas de maneira a dar ênfase às respectivas condicionantes. As condicionantes nessa análise foram identificadas ainda na fundamentação teórica. Com a descrição conceitual essas mesmas condicionantes foram exploradas em um contexto de criação, entrega e consumo do valor. Com isso essas condicionantes foram novamente referenciadas na seção relativa às considerações do modelo. Por fim, a submissão dessas condicionantes à avaliação pelo processo de simulação computacional viabilizou a análise conduzida na seção anterior.

Com isso são estabelecidas quatro diretrizes principais orientadas pelas condicionantes (visto que as condicionantes relativas ao valor referente ao bem tangível e ao serviço são tratadas pela mesma diretriz). Juntamente a estas diretrizes são expostas estratégias na forma de recomendações para a aplicação das diretrizes na atividade de desenvolvimento do produto. Essas estratégias têm base na análise realizada acerca do comportamento apresentado pela simulação. Também observam o fundamentado acerca dos processos de desenvolvimento do PSS integrantes de metodologias existentes, bem como outras informações métodos, ferramentas, entre outros tópicos abordados ao longo da análise que possam contribuir como recomendações. Com o apoio dessas recomendações as diretrizes podem ser desdobradas em guias de práticas para os esforços de desenvolvimento do produto ou mesmo originar requisitos com base no desempenho dinâmico do sistema para o controle, melhoria ou estabelecimento de características de tal produto. Portanto, essas diretrizes e estratégias consistem em: 
I. Fortalecer a integração de ações voltadas à satisfação do consumidor. Com foco na atividade de desenvolvimento do produto essa diretriz é orientada para a satisfação da qualidade percebida pelo consumidor acerca do conjunto de benefícios referentes ao produto frente a suas expectativas iniciais construídos com base em seus valores e preferências pessoais pela comparação com as ofertas similares ou concorrentes no mercado.

\section{Estratégias propostas:}

- Fortalecer a exploração dos atributos e características que pela percepção do grupo de interesse estabelecem o conjunto de benefícios referentes ao produto frente a seus objetivos e necessidade (e também na relação entre a qualidade requerida e os custos totais exigidos) ao longo de todo o ciclo de vida do PSS.

- Promover ou explorar canais de comunicação buscando monitorar a evolução no tempo da percepção do consumidor acerca da qualidade dos atributos e características do produto.

- Promover o monitoramento da evolução e tendências do mercado identificando o surgimento de novos requisitos para o produto em virtude de produtos ou sistemas concorrentes ou substitutos considerando a extensão e o horizonte de tempo para a realização do ciclo de vida planejado ao PSS.

- Reforçar a gestão do conhecimento (com foco na gestão de requisitos) empregando ou integrando bases de dados e promovendo a construção do conhecimento da evolução dos aspectos ressaltados ao mercado e à percepção do consumidor referente ao produto.

- Desenvolver ou empregar instrumentos e ferramentas voltadas para a avaliação do impacto na percepção do grupo de interesse dos aspectos do produto considerando o contexto específico do sistema nos estágios iniciais do desenvolvimento do PSS.

\section{Fortalecer a integração de ações direcionadas à facilidade de obtenção do valor.}

Essa diretriz orienta as ações da atividade de desenvolvimento no sentido de abordar a capacidade e disponibilidade dos meios logísticos envolvidos na distribuição do bem tangível no sistema e, com isso, contribuir com a facilidade para a obtenção do valor.

\section{Estratégias propostas:}

- Articular informações com os responsáveis pela operacionalização da logística de disponibilização do valor no sistema identificando os fatores de desempenho passíveis de atuação pelo produto.

- Promover a análise dos canais e meios logísticos envolvidos para a disponibilização do valor referente ao produto no sistema objetivando a criação de valor ainda nesta etapa.

- Agregar os aspectos referentes à disponibilização do valor no sistema em arquitetura da base de dados amplas, considerando além dos fatores referentes à percepção do valor também as condições logísticas para a realização do PSS. 
III. Fortalecer a integração de ações direcionadas à facilidade de consumo do valor. Essa diretriz é orientada para as ações que abordam os canais de distribuição dos serviços e sua relação com o bem tangível buscando facilitar o consumo do valor.

\section{Estratégias propostas:}

- Articular informações com os envolvidos na extensão do ciclo de vida devido à agregação de valor por meio dos serviços identificando e correlacionando os parâmetros funcionais dos canais de distribuição dos serviços passíveis de atuação pelo produto.

- Empregar ou desenvolver métodos ou ferramentas que, para o contexto do PSS, possibilitem a conversão dos parâmetros funcionais em requisitos aplicáveis ao processo de desenvolvimento de maneira a mensurar o impacto da atuação no produto na percepção do consumidor e conduzir as soluções de características e propriedades do produto para a viabilização ou facilitação das funcionalidades dos canais de serviços.

- Promover o monitoramento da evolução da satisfação do consumidor relativa aos canais de distribuição dos serviços identificando o surgimento de novos requisitos em toda a extensão da rede de criação de valor do sistema.

- Promover a integração dos aspectos referentes aos canais de serviços em bases de dados que possibilitem a gestão dos requisitos relacionados a tais canais.

IV. Fortalecer a integração de ações direcionadas ao controle e operacionalização da produção e agregação de valor. Essas ações focam as variáveis de processo para viabilizar ou melhorar o desempenho da operacionalização e controle do sistema.

\section{Estratégias propostas:}

- Articular informações com os envolvidos na extensão do ciclo de vida devido à agregação de valor por meio dos serviços identificando e correlacionando os requisitos funcionais (considerando as práticas e processos de controle) passíveis de atuação pelo produto.

- Implementar ou explorar meios para a coleta de informações referentes ao uso do produto junto a rede de prestação (equipe de serviço) integrando a experiência adquirida com a atuação no produto.

- Promover o monitoramento da evolução da satisfação do consumidor referente à utilidade e funcionalidade do produto, em toda a extensão da agregação de valor, identificando oportunidades de melhoria nos parâmetros afins ou o surgimento de novos requisitos de uso.

- Fortalecer os canais de comunicação com a produção para identificar as restrições operacionais (devidas às práticas e processos de controle, ou mesmo outras fontes) e oportunidades de atuação por meio do desenvolvimento do produto para favorecimento das etapas produtivas, e consequentemente, da disponibilização do valor pela produção.

- Empregar ou desenvolver métodos ou ferramentas, para o contexto do PSS, que possibilitem o tratamento dos requisitos funcionais relacionados ao produto no processo de desenvolvimento conduzindo as soluções de características e propriedades do produto de maneira a intervir 
(com impacto determinado) nas variáveis de processo referentes tanto a produção quanto a prestação.

- Promover a integração e inter-relação dos aspectos referentes às características e propriedades do produto em bases de dados que possibilitem a gestão dos requisitos relacionados.

Pode ser percebido que, de maneira geral, as estratégias recomendadas também seguem o paradigma de informação/ação/consequência da Dinâmica de Sistemas, buscando identificar, implantar e acompanhar. Essas estratégias são amplas e abordam tal paradigma para a aplicação de cada diretriz no que se refere ao desenvolvimento do produto para o contexto do PSS. Certamente outras estratégias ainda poderiam ser recomendadas. Portanto, o objetivo destas recomendações não consiste em explorar a fundo as práticas necessárias para a aplicação das diretrizes, principalmente em função da gama de possibilidades de configuração que o PSS pode apresentar para a entrega de um determinado valor. Mas sim, essas recomendações gerais ilustram como as diretrizes propostas podem originar práticas de desenvolvimento do produto ligadas ao contexto do PSS.

Mas também, e não menos importante, o processo que culminou na proposição de tais diretrizes disponibiliza uma referência qualitativa e quantitativa como contribuição para o entendimento do PSS pelos gestores e pesquisadores. O modelo construído como laboratório de aprendizagem pode ter suas fronteiras expandidas agregando outros fatores e, assim, considerando aspectos adicionais do sistema. As considerações finais expostas no capítulo seguinte estabelecem uma visão geral e crítica sobre essa análise.

\section{CONSIDERAÇÕES FINAIS}

As diretrizes apresentadas foram construídas sob um ponto de vista definido e fundamentado e apresentam uma nova perspectiva para as considerações do desenvolvimento do produto integrante do PSS. Essas sugerem que o desenvolvimento não deve focar somente no valor a ser entregue. A coesão do valor entregue à expectativa do consumidor é importante, contudo, produz um reflexo em um aspecto específico do sistema; a satisfação do consumidor. Ou seja, na perspectiva exposta este aspecto é importante, contudo insuficiente. Além da condição de valor foi salientado para a atividade de desenvolvimento o enfoque à facilidade de obtenção e consumo de valor, além das questões operacionais e de controle. Um desenvolvimento englobando tais diretrizes expande a amplitude da atividade de desenvolvimento conduzindo a uma visão mais holística.

Propriamente na visão holística pela qual a análise foi desenvolvida proporcionou o entendimento amplo do fenômeno. A abordagem sistêmica conduz, de fato, a uma interpretação integrada dos 
diferentes aspectos que compõem o fenômeno. Essa visão, por sua vez, provê uma compreensão embasada por diferentes paradigmas oferecendo uma alternativa, não somente de abordagem a problemas pontuais, mas principalmente, uma perspectiva de visão de mundo e aprendizado constante. A consciência da dependência de modelos mentais para a interpretação das diferentes questões que os gestores e os diferentes profissionais se deparam abre margem para que esses mesmos modelos sejam questionados e aprimorados. Dessa maneira os processos decisórios podem ser conduzidos a uma estruturação condizente, as ações justificadas por reflexos futuros e as próprias organizações empresariais podem se reestruturar para uma adaptação mais rápida e harmoniosa ao seu meio.

Assim, tendo base nos resultados obtidos, como principal conclusão desta análise se tem a firmação da empresa como um sistema complexo. A atuação associada com diferentes organismos empresariais enfatiza que o fortalecimento de ações conjuntas para a obtenção dos objetivos comuns é necessário, sobretudo em sistemas sócio técnicos como tais. Políticas amplas que alinhem os objetivos dos elementos (humanos) que compõem o organismo empresarial aos objetivos da empresa podem ser extremamente benéficas para produzir resultados desejados em longos horizontes de tempo.

Essa análise estabelece um ponto de vista a ser considerado no desenvolvimento do PSS. Não único e nem se quer abrangente o suficiente para fornecer constatações irrefutáveis.

Mas sim, um ponto de vista que pode contribuir com os modelos mentais de profissionais da indústria e da academia na abordagem ao Sistema Produto Serviço com o objetivo de obter os benefícios atribuídos a esse sistema em um contexto amplo. 


\section{REFERÊNCIAS}

ABRAMOVICI, M.; BELLALOUNA, F.; GÖBEL, J. C. Adaptive change management for industrial productservice systems. Strojniski Vestnik/Journal of Mechanical Engineering, v. 56, n. 11, p. 696-706, 2010.

ABRAMOVICI, M.; NEUBACH, M.; SCHULZE, M.; SPURA, C. Metadata Reference Model for IPS2 Lifecycle Management. Proceedings of the 1st CIRP Industrial Product- Service Systems (IPS2) Conference, 2009. Cranfield University. 1-2 abr. 268 p.

ALONSO-RASGADO, T. A.; THOMPSON, G.; ELFSTRÖM, B. O. The design of functional (total care) products. Journal of Engineering Design, v. 15, n. 6, p. 510-540, 2004.

ALONSO, M. P. Product service system: benefits and barriers. 2007. (MSc Thesis.). School of Applied Sciences, Cranfield University, London, UK.

ARIENTE NETO, R. Modelo para avaliar o comportamento dinâmico da agregação de serviços no contexto de PSS. 2013. 230 p. Dissertação (Mestrado) - Programa de Pós- Graduação em Engenharia Mecânica, Centro Tecnológico, Universidade Federal de Santa Catarina, Florianópolis, 2013. Disponível em: https://bu.ufsc.br/teses/PEMC1465-D.pdf. Acesso em: 09 fev. 2022.

ARIENTE NETO, R.; FORCELLINI, F. A. Guidelines Related to Performance Restrictions in the ProductService System: A System Dynamics Approach. International Journal of Industrial Engineering, v. 27, n. 4, p. 606-626, 2020.

https://doi.org/10.23055/ijietap.2020.27.4.5417.

AURICH, J. C.; FUCHS, C.; WAGENKNECHT, C. Life cycle oriented design of technical Product-Service Systems. Journal of Cleaner Production, v. 14, n. 17, p. 1480-1494, 2006.

AURICH, J. C.; SCHWEITZER, E.; FUCHS, C. Life cycle management of Industrial Product-Service Systems. In: TAKATA, S. e UMEDA, Y., 14TH CONFERENCE ON LIFE

CYCLE ENGINEERING, 2007. Waseda University, Tokyo. Springer London, 11-13 jun. p.171-176, 2007.

AURICH, J. C.; WOLF, N.; SIENER, M.; SCHWEITZER, E. Configuration of product- service systems. Journal of Manufacturing Technology Management, v. 20, n. 5, p. 591-605, 2009.

BAI, C.; SARKIS, J. Integrating sustainability into supplier selection with grey system and rough set methodologies. International Journal of Production Economics, v. 124, n. 1, p. 252-264, 2010.

BAINES, T. S.; BRAGANZA, A.; KINGSTON, J.; LOCKETT, H.; MARTINEZ, V.;

MICHELE, P.; TRANFIELD, D.; WALTON, I.; WILSON, H. State-of-the-art in product service-systems. Journal of Engineering Manufacture, v. 221, n. 10, p. 1543-1552, 2007.

BEUREN, F. H.; FERREIRA, M. G. G.; MIGUEL, P. A. C. Atualização da literatura vigente sobre sistemas produto-serviço (PSS): uma análise da produção qualificada entre 2006 e 2010.XVIII SIMPÓSIO DE ENGENHARIA DE PRODUÇÃO. São Paulo, Brasil,2011.

BIANCHI, N. P.; EVANS, S.; REVETRIA, R.; TONELLI, F. Influencing factors of 
successful transitions towards product-service systems: A simulation approach. International Journal of Mathematics and Computers in Simulation, v. 3, n. 1, p. 30-43, 2009.

BRANDSTOTTER, M.; HABERL, M.; KNOTH, R.; KOPACEK, B.; KOPACEK, P. IT on

demand-towards an environmental conscious service system for Vienna (AT). In: ENVIRONMENTALLY CONSCIOUS DESIGN AND INVERSE MANUFACTURING, 2003. ECODESIGN'03.2003 3RD INTERNATIONAL SYMPOSIUM ON.IEEE, 2003. p.

799-802.

BRASIL MAIOR. Inovar para competir. Competir para crescer. [Brasília]: [s.n.], [2011]. 24p. Disponível em: <http://www.brasilmaior.mdic.gov.br/wp-content/uploads/cartilha_brasilmaior.pdf >.Acesso em: 04-08-2011.

BUI, H.; BARUCH, Y. Creating learning organizations: a systems perspective. The Learning Organization, v. 17, n. 3, p. 10, 2010.

BUXTON, D.; FARR, R.; MCCARTHY, B. The aero-engine value chain under future business environments: using agent-based simulation to understand dynamic behaviour. Proceedings of the MITIP2006, 2006.

CENTRE FOR SUSTAINABLE DESIGN. Sustainable service-systems (3S). Transition towards sustainability. In: SIXTH INTERNATIONAL CONFERENCE, 2002.

CESCHIN, F.; VEZZOLI, C. The role of public policy in stimulating radical environmental impact reduction in the automotive sector: The need to focus on product- service system innovation. International Journal of Automotive Technology and Management, v. 10, n. 2-3, p. 321-341, 2010.

COYLE, R. G. System Dynamics Modelling: A Practical Approach. Chapman \& Hall, 1996. 432 p.

DALÉ, L. B. C.; ROLDAN, L. B.; HANSEN, P. B. Analysis of sustainability incorporation by industrial supply chain in Rio Grande do Sul State (Brazil). Journal of Operations and Supply Chain Management, v. 4, n. 1, p. 25-36, 2011.

EHRENFELD, J. Designing sustainable product/service systems. Environmentally Conscious Design and Inverse Manufacturing, 2001. Proceedings EcoDesign 2001: Second International Symposium on, 2001. IEEE. p.12-23.

EVANS, S.; PARTIDÁRIO, P. J.; LAMBERT, J. Industrialization as a key element of sustainable productservice solutions. International Journal of Production Research, v. 45, n. 18-19, p. 4225-4246, 2007.

FORRESTER, J. W. Industrial Dynamics. Massachusetts Institute of Technology Press, 1961. 464 p.

. System Dynamics and Learner-Centered-Learning in Kindergarten through 12th Grade Education. Technical Report D-4337, MIT System Dynamics in Education Project. 1992

. Road Maps 2: A Guide to Learning System Dynamics. Technical Report D-4502- 6, MIT System Dynamics in Education Project. 1993. 
. Road Map 1: A Guide to Learning System Dynamics. Technical Report D-4501- 7, MIT System Dynamics in Education Project. 2005.

FORRESTER, J. W.; SENGE, P. M. Test for Building Confidence in System Dynamics Models. TIMS studies in the Management Sciences, n. 14, p. 209-228, 1980.

GENG, X.; CHU, X.; XUE, D.; ZHANG, Z. A systematic decision-making approach for the optimal productservice system planning. Expert Systems with Applications, v. 38, n. 9, p. 11849-11858, 2011.

GOEDKOOP, M. J.; VAN HALEN, C. J. G.; TE RIELE, H. R. M.; ROMMENS, P. J. M.

Product Service Systems: Ecological and Economic Basics. Report for Dutch Ministries of Environment (VROM) and Economic Affairs (EZ), 1999.

HARA, T.; ARAI, T.; SHIMOMURA, Y. A Concept of Service Engineering: A Modeling Method and A Tool for Service Design. Service systems and service management, 2006 International Conference on. Troyes: IEEE: 13-18 p. 2006.

HARA, T.; ARAI, T.; SHIMOMURA, Y.; SAKAO, T. Service CAD system to integrate product and human activity for total value. CIRP Journal of Manufacturing Science and Technology, v. 1, n. 4, p. 262-271, 2009.

HOFFMAN, K., D.; BATESON, J. E. G. Princípios de marketing de serviços: conceitos, estratégias e casos. 2 ed. São Paulo: Pioneira, 2002. 600 p.

HUANG, G. Q. Design for X: Concurrent Engineering Imperatives. Chapman \& Hall, 1996. 489 p.

INSTITUTO BRASILEIRO DE GEOBRAFIA E ESTATÍSTICA. Indicadores IBGE.

Contas nacionais trimestrais: Indicadores de volume e valores correntes. Outubro / Dezembro 2012. [s.l.: s.n.]: 43 p. [2013]. Disponível em:

<ftp://ftp.ibge.gov.br/Contas_Nacionais/Contas_Nacionais_Trimestrais/Fasciculo_Indicadore s_IBGE/2012/pib-vol-val_201204caderno.pdf >.Acesso em: 18-10-2013.

JACKSON, M. C. Systems thinking: creative holism for managers. John Wiley \& Sons, 2007. 376 p.

JIN, S.; LIYA, W. A methodology based on Fuzzy Extended Quality Function Deployment for determining optimal engineering characteristics in product-service system design. SERVICE OPERATIONS AND LOGISTICS, AND INFORMATICS, 2008. IEEE/SOLI 2008. IEEE INTERNATIONAL CONFERENCE ON, 2008. 12-15 out. 2008. p.331-336.

KAZEMI, M. A. A.; ESHLAGHY, A. T.; TAVASOLI, S. Developing the product strategy via product life cycle simulation according to the system dynamics approach. Applied Mathematical Sciences, v. 5, n. 17, p. 845-862, 2011.

KHAN, Z. Design for assembly. Assembly Automation, v. 28, n. 3, p. 200-206, 2008.

KIM, Y. S.; WANG, E.; LEE, S. W.; CHO, Y. C. A Product-Service System Representation and Its Application in a Concept Design Scenario. Proceedings of the 1st CIRP Industrial Product-Service Systems (IPS2) Conference. Cranfield UniversityPress, 2009. 
KIMITA, K.; SHIMOMURA, Y.; ARAI, T. Evaluation of customer satisfaction for PSS design. Journal of Manufacturing Technology Management, v. 20, n. 5, p. 654-673, 2009.

KOMOTO, H.; TOMIYAMA, T. Integration of a service CAD and a life cycle simulator. CIRP Annals Manufacturing Technology, v. 57, n. 1, p. 9-12, 2008.

KOMOTO, H.; TOMIYAMA, T.; NAGEL, M.; SILVESTER, S.; BREZET, H. Life Cycle

Simulation for Analyzing Product Service Systems. In: Environmentally Conscious Design and Inverse Manufacturing, 2005. Eco Design 2005. Fourth International Symposium on. IEEE. 2005. p. 386-393.

KOTLER, P. Administração de marketing: análise, planejamento, implementação e controle. 5 ed. São Paulo: Atlas, 1998. 725 p.

KUO, T. C.; MA, H. Y.; HUANG, S. H.; HU, A. H.; HUANG, C. S. Barrier analysis for

product service system using interpretive structural model. The International Journal of Advanced Manufacturing Technology, v. 49, n. 1-4, p. 407-417, 2010.

LAI, C. L.; LEE, W. B.; IP, W. H. A study of system dynamics in just-in-time logistics. Journal of Materials Processing Technology, v. 138, n. 1-3, p. 265-269, 2003.

LAS CASAS, A. L. Marketing de serviços. São Paulo: Atlas, 1991. 163 p.

LELAH, A.; MATHIEUX, F.; BRISSAUD, D. Contributions to eco-design of machine-to- machine product service systems: The example of waste glass collection. Journal of Cleaner Production. v. 19, n. 9-10, p. 1033-1144, 2011.

LOVELOCK, C.; WIRTZ, J.; HEMZO, M. A. Marketing de serviços: pessoas, tecnologia e estratégia. 7 ed. São Paulo: Pearson Prentice Hall, 2011. 530 p.

LOW, M. K.; LAMVIK, T.; WALSH, K.; MYKLEBUST, O. Product to service eco- innovation: the TRIZ model of creativity explored. Electronics and the Environment, 2000. ISEE 2000. Proceedings of the 2000 IEEE International Symposium on, 2000. p. 209-214.

MANZINI, E.; VEZOLLI, C. O desenvolvimento de produtos sustentáveis: os requisitos ambientais dos produtos industriais.São Paulo: Edusp, 2002. 366 p.

MANZINI, E.; VEZOLLI, C. A strategic design approach to develop sustainable product service systems: examples taken from the 'environmentally friendly innovation' Italian prize. Cleaner Production, v. 11, n. 8, p. 851-857, 2003.

MARTIN, L. A. The first step. Technical Report D-4694, MIT System Dynamics in Education Project. 1997.

MATTOS, D. L.; ARIENTE NETO, R.; MERINO, E. A. D.; FORCELLINI, F. A.

Simulating the influence of physical overload on assembly line performance: A case study in an automotive electrical component plant. Applied Ergonomics, v.79, p. 107-121, 2019. https://doi.org/10.1016/j.apergo.2018.08.001 
MAUSSANG, N.; SAKAO, T.; ZWOLINSKI, P.; BRISSAUD, D. A model for designing

product-service systems using functional analysis and agent based model. Proceedings of the 16th International Conference on Engineering Design (ICED07). Paris, France: 11 p. p. 2007.

MAUSSANG, N.; ZWOLINSKI, P.; BRISSAUD, D. Evaluation of Product-Service Systems During Early Design PhaseManufacturing Systems and Technologies for the New Frontier. In: MITSUISHI, M.; UEDA, K., et al (Ed.): Springer London, 2008. p.547- 552.

MAXWELL, D.; SHEATE, W.; VAN DER VORST, R. Functional and systems aspects of the sustainable product and service development approach for industry. Journal of Cleaner Production, v. 14, n. 17, p. 1466-1479, 2006.

MÉLÈSE, J. A gestão pelos sistemas. Rio de Janeiro: Ao Livro Técnico, 1973. 260 p.

MEPSS Webtool. [2011?]. Disponível em: < http://www.mepss.nl/ >. Acesso em: 25-11- 2011.

MONT, O. Introducing and developing a Product-Service System (PSS) concept in Sweden [Elektronisk resurs]. IIIEE Reports, p. 6, 2001.

. Clarifying the concept of product-service system. Journal of Cleaner Production, v. 10, n. 3, p. 237-245, 2002.

. Product-service Systems: Panacea of Myth? VDM Verlah, 2004.

MORELLI, N. Product-service systems, a perspective shift for designers: A case study: the design of a telecentre. Design Studies, v. 24, n. 1, p. 73-99, 2003.

MORELLI, N. Developing new product service systems (PSS): methodologies and operational tools. Journal of Cleaner Production, v. 14, n. 17, p. 1495-1501, 2006.

MULLER, P.; BLESSING, L. Development of product-service-systems -comparison of product and service development process models. In : Proceedings of the international conference on engineering design ICED’07 Paris, France 2007.

MÜLLER, P.; KEBIR, N.; STARK, R.; BLESSING, L. PSS Layer Method - Application to Microenergy Systems. Introduction to Product/Service-System Design. In: SAKAO, T. e LINDAHL, M. (Ed.). Introduction to Product/Service-System Design. New York: Springer London, 2009. p. 3-30.

NICKELS, W. G.; WOOD, M. B. Marketing: relacionamentos, qualidade, valor. Rio de Janeiro: LTc, 1999.

OGATA, K. System Dynamics. 2 ed. United States of America: Prentice-Hall International, 1998. 758 p.

OLIVER, R. L. Satisfaction: A Behavioural Perspective on the Customer. Boston: McGraw- Hill, 1997.

OLSSON, A.; LARSSON, A. C. Value Creation in PSS Design Through Product and Packaging Innovation Processes. In: SAKAO, T. e LINDAHL, M. (Ed.). Introduction to Product/Service-System Design. New York: Springer London, 2009. p.93-109. 
PAHL, G.; BEITZ, W.; FELDHUSEN, J.; GROTE, K. H. Projeto na engenharia: fundamentos do desenvolvimento eficaz de produtos métodos e aplicações. 6 ed. São Paulo: Edgard Blucker, 2005. 411 p.

PARASURAMAN, A.; BERRY, L. L.; ZEITHAML, V. A. SERVQUAL: A Multiple-Item

Scale for Measuring Consumer Perceptions of Service Quality. Journal of Retailing, v. 64, n. 1, p. 12-40, 1988.

PHUMBUA, S.; TJAHJONO, B. Towards product-service systems modelling: a quest for dynamic behaviour and model parameters. International Journal of Production Research, p. 1-18, 2011.

RESE, M.; KARGER, M.; STROTMANN, W.-C. The dynamics of industrial product service systems (IPS2)using the net present value approach and real options approach to improve life cycle management. CIRP Journal of Manufacturing Science and Technology, v. 1, n. 4, p. 279-286, 2009.

RICHTER, A.; SADEK, T.; STEVEN, M. Flexibility in industrial product-service systems and use-oriented business models. CIRP Journal of Manufacturing Science and Technology, v. 3, n. 2, p. 128-134, 2010.

ROZENFELD, H.; FORCELLINI, F. A.; AMARAL, D. C.; DE TOLEDO, J. C.; DA SILVA,

S. L.; ALLIPRANDINI, D. H.; SCALICE, R. K. Gestão de desenvolvimento de produtos: uma referência para a melhoria do processo. Saraiva, 2006. 542 p.

SAKAO, T.; SHIMOMURA, Y. A Novel Design Methodology for Services to Increase Value Combining Service and Product based on Service Engineering. Environmentally Conscious Design and Inverse Manufacturing, 2005. Eco Design 2005. Fourth International Symposium on. Tokyo: 8 p. 2005.

SCHUH, G.; BOOS, W.; KOZIELSKI, S. Life Cycle Cost-Orientated Service Models for Tool and Die Companies. Proceedings of the 1st CIRP Industrial Product-Service Systems (IPS2) Conference. Cranfield University 2009.

SCHUH, G.; GUDERGAN, G. Service Engineering as an Approach to Designing Industrial Product Service Systems. Proceedings of the 1st CIRP Industrial Product-Service Systems (IPS2) Conference. Cranfield University 2009.

SENGE, P. M.; ROSS, R.; ROBERTS, C.; KLEINER, A.; SMITH, B. A quinta disciplina:

caderno de campo: estratégias e ferramentas para construir uma organização que aprende.Qualitymark, 1999. 544 p.

SENGE, P. M.; STERMAN, J. D. Systems thinking and organizational learning: Acting locally and thinking globally in the organization of the future. European Journal of Operational Research, v. 59, n. 1, p. 137150, 1992.

SIRDESHMUKH, D.; SINGH, J.; SABOL, B. Consumer Trust, Value, and Loyalty in Relational Exchanges. Journal of Marketing, v. 66, n. 1, p. 15-37, 2002. 
STANKE, A.; MURMAN, E. A framework for achieving lifecycle value in aerospace product development: International Council of Aeronautical Sciences: 10 p. 2002. Disponível em: <http://hdl.handle.net/1721.1/7317>.

STERMAN, J. D. Appropriate Summary Statistics for Evaluating the Historical Fit of System Dynamists Models. Dynamica, v. 10, n. part II, p. 51-66, 1984.

STERMAN, J. D. Business Dynamics: Systems Thinking and Modeling for a Complex World. McGrawHill, 2000. 982 p.

TUKKER, A. Eight types of product-service system: eight ways to sustainability?

Experiences from SusProNet. Business Strategy and the Environment, v. 13, n. 4, 2004.

TUKKER, A.; TISCHNER, U. New business for old Europe: product service development, competitiveness and sustainability. UK: Greenleaf, 2006. 479 p.

VENTANA SYSTEM. Vensim Software. 2012. Disponível em: <http://www.vensim.com/>. Acesso em: 04-09-2012.

VEZZOLI, C. System design for sustainability: Theory, methods and tools for a sustainable "satisfactionsystem" design.Milano, Italy: Maggioli Edtore, 2007. 260 p.

VON BERTALANFFY, L. Teoria geral dos sistemas: fundamentos, desenvolvimento e aplicações.Vozes, 2008. $360 \mathrm{p}$.

WANG, P. P.; MING, X. G.; LI, D.; KONG, F. B. W. L.; WU, Z. Y. Modular Development

of Product Service Systems. Concurrent Engineering: Research and Applications, v. 19, n. 1, p. 85-96, 2011.

WEBER, C.; STEINBACH, M.; BOTTA, C.; DEUBEL, T. Modelling of product-service systems (PSS) based on the PDD approach. Proceedings of the international design conference - Design 200. Dubrovnik, Croatia: Saarländische Universitäts - und Landesbibliothek: 547-554 p. 2004. Disponível em: <http://scidok.sulb.uni- saarland.de/volltexte/2008/1619/>.

WILLIAMS, A. Product service systems in the automobile industry: contribution to system innovation? Journal of Cleaner Production, v. 15, n. 1, p. 1093-1103, 2007.

WIMMER, R.; KANG, M.J.; TISCHNER, U.; VERKUIJL, M.; FRESNER, J.; MÖLLER, M.

Erfolgsstrategien für Produkt-Dienstleistungssysteme. Berichte aus Energie-und Umweltforschung. Vienna: Austria, 2007.

WONG, M. Implementation of innovative product service-systems in the consumer goods industry. 2004. (PhD Thesis). Cambridge University.

WOODRUFF, R. Customer Value: the next source for competitive advantage. Journal of the Academy of Marketing Science, v. 25, n. 2, p. 139-153, 1997. 
YOON, B.; KIM, S.; RHEE, J. An evaluation method for designing a new product-service system. Expert Systems with Applications, v. 39, n. 3, p. 3100-3108, 2012.

ZEITHAML, V. Consumer Perceptions of Price, Quality, and Value: A means-end Model and Synthesis of Evidence. Journal of Marketing, v. 52, n. 3, p. 2-22, 1988.

ZHAI, L. A system dynamics approach to supplier partnership management in supply chain. 2004. (Master). Engineering Systems Division, Massachusetts Institute of Technology.

ZHANG, Y.; DILTS, D. System dynamics of supply chain network organization structure. Information Systems and E-Business Management, v. 2, n. 2, p. 187-206, 2004. 
APÊNDICE

APÊNDICE A- Estrutura do modelo
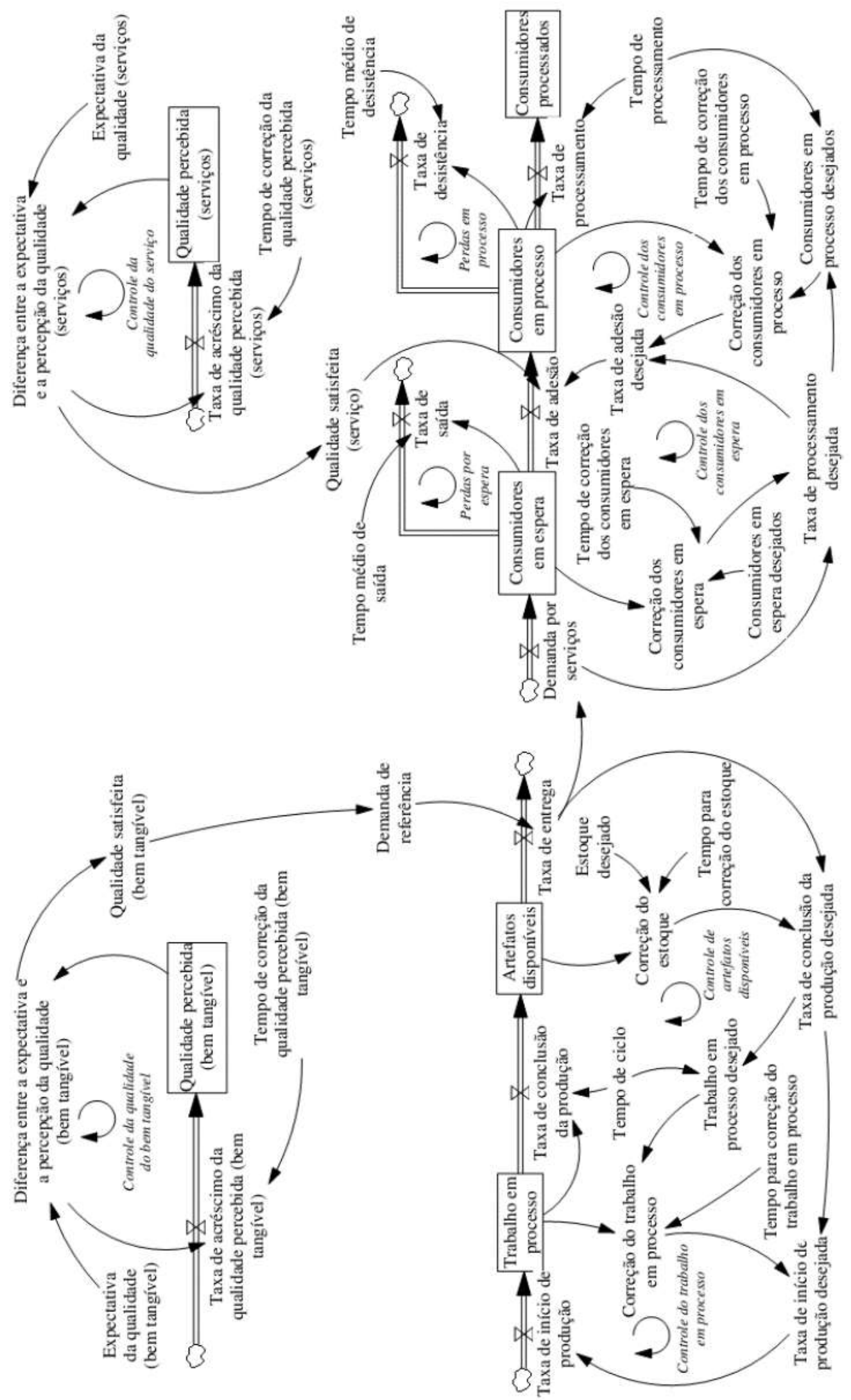


\section{APÊNDICE B- Variáveis e equações do modelo}

\begin{tabular}{|c|c|c|c|}
\hline Rótulo & $\begin{array}{c}\text { Nome } \\
\text { nclat } \\
\text { ura }\end{array}$ & Equações & Unidade \\
\hline \multirow{2}{*}{ Artefatos disponíveis } & \multirow{2}{*}{$A D$} & $A D_{T}=\int_{T_{0}}^{T}\left[T x C_{(t)}-T x E_{(t)}\right] d t+A D_{T_{0}}$ & \multirow{2}{*}{ Artefatos } \\
\hline & & $\frac{d(A D)}{d t}=T x C_{(t)}-T x E_{(t)}$ & \\
\hline \multirow{2}{*}{ Trabalho em processo } & \multirow{2}{*}{$T P$} & $T P_{T}=\int_{T_{0}}^{T}\left[T x I_{(t)}-T x C_{(t)}\right] d t+T P_{T_{0}}$ & \multirow{2}{*}{ Artefatos } \\
\hline & & $\frac{d(T P)}{d t}=T x I_{(t)}-T x C_{(t)}$ & \\
\hline Taxa de entrega & $T x E$ & $T x E_{(t)}=D R_{(t)}$ & $\frac{\text { Artefatos }}{\text { Semana }}$ \\
\hline $\begin{array}{l}\text { Taxa de conclusão da } \\
\text { produção }\end{array}$ & $T x C$ & $T x C_{(t)}=\frac{T P_{(t)}}{T e C}$ & $\frac{\text { Artefatos }}{\text { Semana }}$ \\
\hline $\begin{array}{l}\text { Taxa de início de } \\
\text { produção }\end{array}$ & $T x I$ & $\begin{array}{c}T x I_{(t)}=\operatorname{TxId}_{(t)} \\
\text { sendo: } \quad f(x) \geq 0\end{array}$ & $\frac{\text { Artefatos }}{\text { Semana }}$ \\
\hline $\begin{array}{l}\text { Taxa de início de } \\
\text { produção desejada }\end{array}$ & TxId & $\operatorname{TxId}(t)=\operatorname{TxC} d_{(t)}+\operatorname{CrTP}(t)$ & $\frac{\text { Artefatos }}{\text { Semana }}$ \\
\hline $\begin{array}{l}\text { Correção do trabalho em } \\
\text { processo }\end{array}$ & $\begin{array}{c}C r T \\
P\end{array}$ & $\operatorname{CrTP}(t)=\frac{\left(T P d_{(t)}-T P_{(t)}\right)}{T e T P}$ & $\frac{\text { Artefatos }}{\text { Semana }}$ \\
\hline $\begin{array}{l}\text { Trabalho em processo } \\
\text { desejado }\end{array}$ & $T P d$ & $T P d_{(t)}=T x C d_{(t)} \cdot T e C$ & Artefatos \\
\hline $\begin{array}{l}\text { Taxa de conclusão da } \\
\text { produção desejada }\end{array}$ & $\begin{array}{c}T x C \\
d\end{array}$ & $\begin{array}{l}T x C d_{(t)}=\operatorname{Cr} A D_{(t)}+T x E_{(t)} \\
\text { sendo: } \quad f(x) \geq 0\end{array}$ & $\frac{\text { Artefatos }}{\text { Semana }}$ \\
\hline Correção do estoque & $\begin{array}{c}C r A \\
D\end{array}$ & ${\operatorname{Cr} A D_{(t)}}=\frac{\left(A D d-A D_{(t)}\right)}{\operatorname{TeAD}}$ & $\frac{\text { Artefatos }}{\text { Semana }}$ \\
\hline \multirow[t]{2}{*}{ Consumidores em espera } & \multirow[t]{2}{*}{$C E$} & $\begin{array}{c}C E_{T}=\int_{T_{0}}^{T}\left[D e S_{(t)}-T x A_{(t)}-T x S_{(t)}\right] d t \\
+C E_{T_{0}}\end{array}$ & \multirow[t]{2}{*}{$\begin{array}{l}\text { Consumidore } \\
\mathrm{s}\end{array}$} \\
\hline & & $\frac{d(C E)}{d t}=D e S_{(t)}-T x A_{(t)}-T x S_{(t)}$ & \\
\hline \multirow[t]{2}{*}{$\begin{array}{l}\text { Consumidores em } \\
\text { processo }\end{array}$} & \multirow[t]{2}{*}{$C P$} & $\begin{array}{c}C P_{T}=\int_{T_{0}}^{T}\left[T x A_{(t)}-T x P_{(t)}-T x D_{(t)}\right] d t \\
+C P_{T_{0}}\end{array}$ & \multirow[t]{2}{*}{$\begin{array}{l}\text { Consumidore } \\
\mathrm{s}\end{array}$} \\
\hline & & $\frac{d(C P)}{d t}=T x A_{(t)}-T x P_{(t)}-T x D_{(t)}$ & \\
\hline
\end{tabular}




\begin{tabular}{|c|c|c|c|}
\hline \multirow{2}{*}{$\begin{array}{l}\text { Consumidores } \\
\text { processados }\end{array}$} & \multirow{2}{*}{$C P R$} & $C P R_{T}=\int_{T_{0}}\left[T x P_{(t)}\right] d t+C P R_{T_{0}}$ & \multirow{2}{*}{$\begin{array}{c}\text { Consumidore } \\
\mathrm{s}\end{array}$} \\
\hline & & $\frac{d(C P R)}{d t}=T x P_{(t)}$ & \\
\hline \multirow{2}{*}{ Taxa de adesão } & \multirow{2}{*}{$T x A$} & \multirow{2}{*}{$\begin{array}{c}T x A_{(t)}=T x A d_{(t)} \cdot Q S S \\
\text { sendo: } f(x) \geq 0\end{array}$} & Consumidore \\
\hline & & & Semana \\
\hline \multirow{2}{*}{ Taxa de adesão desejada } & \multirow{2}{*}{$T x A d$} & \multirow{2}{*}{$\operatorname{TxAd}(t)=\operatorname{TxP} d_{(t)}+\operatorname{CrCP}(t)$} & Consumidore \\
\hline & & & Semana \\
\hline \multirow{2}{*}{$\begin{array}{l}\text { Correção dos } \\
\text { consumidores em } \\
\text { processo }\end{array}$} & \multirow{2}{*}{$\begin{array}{c}\mathrm{CrC} \\
P\end{array}$} & \multirow{2}{*}{$\operatorname{CrCP}_{(t)}=\frac{\left(C P d_{(t)}-C P_{(t)}\right)}{\operatorname{TeCP}}$} & Consumidore \\
\hline & & & Semana \\
\hline $\begin{array}{l}\text { Consumidores em } \\
\text { processo desejados }\end{array}$ & $C P d$ & $C P d_{(t)}=T x P d_{(t)} \cdot T e P$ & $\begin{array}{c}\text { Consumidore } \\
\mathrm{s}\end{array}$ \\
\hline \multirow{2}{*}{$\begin{array}{l}\text { Taxa de processamento } \\
\text { desejada }\end{array}$} & \multirow{2}{*}{$T x P d$} & \multirow{2}{*}{$T x P d_{(t)}=\operatorname{CrCE} E_{(t)}+D e S_{(t)}$} & Consumidore \\
\hline & & & Semana \\
\hline \multirow{2}{*}{$\begin{array}{l}\text { Correção dos } \\
\text { consumidores em espera }\end{array}$} & \multirow{2}{*}{$\begin{array}{c}C r C \\
E\end{array}$} & \multirow{2}{*}{$\operatorname{CrCE}(t)=\frac{\left(C E_{(t)}-C E d\right)}{T e C E}$} & Consumidore: \\
\hline & & & Semana \\
\hline \multirow{2}{*}{ Taxa de processamento } & \multirow{2}{*}{$T x P$} & \multirow{2}{*}{$T x P_{(t)}=\frac{C P_{(t)}}{T e P}$} & Consumidore \\
\hline & & & Semana \\
\hline \multirow{2}{*}{ Taxa de saída } & \multirow{2}{*}{$T x S$} & \multirow{2}{*}{$T x S_{(t)}=\frac{C E_{(t)}}{T e S}$} & Consumidore \\
\hline & & & Semana \\
\hline \multirow{2}{*}{ Taxa de desistência } & \multirow{2}{*}{$T x D$} & \multirow{2}{*}{$T x D_{(t)}=\frac{C P_{(t)}}{T e D}$} & Consumidore \\
\hline & & & Semana \\
\hline \multirow{2}{*}{$\begin{array}{l}\text { Qualidade percebida (bem } \\
\text { tangível) }\end{array}$} & \multirow{2}{*}{$Q P A$} & $Q P A_{T}=\int_{T_{0}}^{T}\left[T x P A_{(t)}\right] d t+Q P A_{T_{0}}$ & \\
\hline & & $\frac{d(Q P A)}{d t}=T x P A_{(t)}$ & \\
\hline \multirow{2}{*}{$\begin{array}{l}\text { Qualidade percebida } \\
\text { (serviço) }\end{array}$} & \multirow[t]{2}{*}{$Q P S$} & $Q P S_{T}=\int_{T_{0}}^{T}\left[T x P S_{(t)}\right] d t+Q P S_{T_{0}}$ & \\
\hline & & $\frac{d(Q P S)}{d t}=T x P S_{(t)}$ & \\
\hline $\begin{array}{l}\text { Diferença entre a } \\
\text { percepção e a expectativa } \\
\text { da qualidade (bem } \\
\text { tangível) }\end{array}$ & $(\triangle A)$ & $\Delta A_{(t)}=E A-Q P A_{(t)}$ & \\
\hline $\begin{array}{l}\text { Diferença entre a } \\
\text { percepção e a expectativa } \\
\text { da qualidade (serviço) }\end{array}$ & $(\Delta S)$ & $\Delta S_{(t)}=E S_{(t)}-Q P S_{(t)}$ & \\
\hline
\end{tabular}




\begin{tabular}{|l|c|c|c|}
\hline $\begin{array}{l}\text { Taxa de acréscimo da } \\
\text { qualidade percebida (bem } \\
\text { tangível) }\end{array}$ & $\begin{array}{c}T x P \\
A\end{array}$ & $\operatorname{TxPA}_{(t)}=\frac{\Delta A_{(t)}}{T e Q A}$ & \\
\hline $\begin{array}{l}\text { Taxa de acréscimo da } \\
\text { qualidade percebida } \\
\text { (serviço) }\end{array}$ & $\operatorname{TxPS}$ & $\operatorname{TxPS}_{(t)}=\frac{\Delta S_{(t)}}{T e Q S}$ & \\
\hline Demanda de referência & $D R$ & $D R=\left\{15+\left[5 \cdot \sin \left(2 \cdot \pi \cdot \frac{t}{12}\right)\right]\right\} \cdot Q S A$ & $\frac{\text { Artefatos }}{\text { Semana }}$ \\
\hline
\end{tabular}


APÊNDICE C - Constantes do modelo

\begin{tabular}{|c|c|c|}
\hline Rótulo & $\begin{array}{l}\text { Nomen- } \\
\text { clatura }\end{array}$ & Unidade \\
\hline Artefatos disponíveis iniciais & $A D_{T_{0}}$ & Artefatos \\
\hline Trabalho em processo inicial & $T P_{T_{0}}$ & Artefatos \\
\hline Tempo para correção do trabalho em processo & TeTP & Semanas \\
\hline Tempo de ciclo & $\mathrm{TeC}$ & Semanas \\
\hline Estoque desejado & $A D d$ & Artefatos \\
\hline Tempo para correção do estoque & $T e A D$ & Semanas \\
\hline Consumidores em processo iniciais & $C P_{T_{0}}$ & Consumidores \\
\hline Consumidores processados iniciais & $C P R_{T_{0}}$ & Consumidores \\
\hline Tempo de processamento & $\mathrm{TeP}$ & Semanas \\
\hline Tempo de correção dos consumidores em processo & $\mathrm{TeCP}$ & Semanas \\
\hline Tempo de correção dos consumidores em espera & $\mathrm{TeCE}$ & Semanas \\
\hline Consumidores em espera desejados & $C E d$ & Consumidores \\
\hline Qualidade percebida (bem tangível) inicial & $Q P A_{T_{0}}$ & \\
\hline Qualidade percebida (serviço) inicial & $Q P S_{T_{0}}$ & \\
\hline Expectativa da qualidade (bem tangível) & $E A$ & \\
\hline Expectativa da qualidade (serviço) & $E S$ & \\
\hline $\begin{array}{l}\text { Tempo de correção da qualidade percebida (bem } \\
\text { tangível) }\end{array}$ & $T e Q A$ & Semanas \\
\hline Tempo de correção da qualidade percebida (serviços) & $T e Q S$ & Semanas \\
\hline Tempo médio de saída & $\mathrm{TeS}$ & Semanas \\
\hline Tempo médio de desistência & $T e D$ & Semanas \\
\hline
\end{tabular}




\section{NOTAS}

\section{Nota 1}

Valores calculados a partir das contas nacionais trimestrais considerando o "valor adicionado das atividades" (INSTITUTO BRASILEIRO DE GEOBRAFIA E ESTATÍ́STICA, [2013]).

\section{Nota 2}

A comoditização dos bens refere-se à diminuição de seus ciclos de vida e sua rápida generalização provocada pela diminuição do tempo para o seu lançamento no mercado e/ou a impossibilidade de lançamento de bens inovadores (KIMITA; SHIMOMURA; ARAI, 2009).

Nota 3

Termo que se refere a qualquer grupo ou indivíduo com interesse (influenciando ou sendo influenciado) pelas atividades ou produtos do sistema (JACKSON, 2007).

\section{Nota 4}

Tal abordagem foi adotada pelas disciplinas gerenciais que transferiram para o estudo das organizações as considerações dadas pelas publicações de Bertalanffy na década de 1950 (JACKSON, 2007).

Nota 5

Pelas considerações relativas aos limites que separam os sistemas do seu meio, as constatações de hierarquias e capacidade de assumir certo grau de autonomia, se estabeleceu um melhor entendimento sobre as características dos sistemas em função de uma abordagem diferenciando sistemas fechados e sistemas abertos (VON BERTALANFFY, 2008). Em analogia com o organismo biológico, um sistema aberto estabelece relações com seu meio recebendo e respondendo a estímulos de forma a adaptar-se para manter sua própria existência. Quando, em contra partida, um sistema fechado é considerado como isolado do seu meio.

\section{Nota 6}

De uma forma ampla e genérica um produto pode ser considerado como "um bem; um serviço ou uma ideia, que um consumidor adquire para satisfazer uma necessidade ou um desejo" (NICKELS; WOOD, 1999). Segundo esta definição o produto é visto como o bem tangível ou intangível (sendo que o serviço consistiria no produto do desempenho de uma ou mais atividades de prestação, e, da mesma forma, a ideia consistiria no produto de uma ou mais atividades intelectuais) comercializável que atende necessidades específicas. Então, por rigor semântico nos contextos não implícitos em que o termo "produto" se referir aos bens manufaturados esses são referenciados como "bens tangíveis" ou artefatos físicos.

\section{Nota 7}

O valor, genericamente, refere-se a utilidade ou benefícios atribuídos a um bem tangível(ZEITHAML, 1988) ou aos benefícios atribuídos a um serviço (SIRDESHMUKH; SINGH; SABOL, 2002). Uma maior explanação sobre o "valor" é conduzida na Seção 3.1.3.

\section{Nota 8}

Simplificadamente, um sistema é um todo complexo, cujo funcionamento depende de suas partes e das interações entre elas (JACKSON, 2007).

\section{Nota 9}

Quando um sistema apresenta suas saídas atuais em dependência das entradas antecedentes é denominado de sistema dinâmico; já quando as saídas atuais dependem unicamente das entradas atuais é denominado de sistema estático (OGATA, 1998).

Nota 10 
$O$ " $X$ " representa o enquadramento específico (dos princípios) desta abordagem. Cada orientação (X) aborda particularidades que são devidas a um determinado fator (relacionado ao ciclo de vida) que afeta as características de um produto. Como exemplo de orientações do DFX podem ser citados o DFM (Design for Manufacture) cujos princípios concentram-se no âmbito da fabricação (projeto para a manufatura), o DFA (Design for Assembly) concentrado nos aspectos relacionados à montagem (projeto para a montagem), o DFS (Design for Service) voltado aos serviços (projeto para os serviços) entre outros. Mais informações gerais sobre as abordagens DFX podem ser obtidas com Huang (1996).

Nota 11

Modelos mentais referem-se à visão de mundo de cada indivíduo, para cada caso. São constituídos de uma mistura de compreensão e valores reunidos ao longo de suas experiências e de sua educação (JACKSON, 2007). Os modelos mentais determinam a forma de pensar ou a estrutura de análise de um caso.

Nota 12

Um sistema apresenta estruturas de malha aberta (open-loop) que conduzem a informação em uma cadeia linear de causa e efeito e estruturas de malha fechada (close-loop) ou, como também são conhecidos, ciclos de realimentação (feedback loop) nos quais as reações desencadeadas pela mudança em um dos fatores do sistema percorrem um caminho que as conduzem novamente a essa variável. Em um ciclo de realimentação um fator é, ao mesmo tempo, causa e efeito.

Nota 13

Comportamento tipicamente observado para sistemas constituídos pela mesma estrutura sistêmica de condução da informação.

Nota 14

O software VenSim não é o único software de modelagem pela linguagem da Dinâmica de Sistemas disponível. STELLA, Powersim e DYNAMO são outros três pacotes de softwares usados com frequência em atividades profissionais e acadêmicas.

Nota 15

A satisfação é um julgamento do consumidor das características dos atributos referentes ao bem tangível ou ao serviço, ou do próprio bem ou serviço prestado ou em prestação (OLIVER, 1997).

\section{Nota 16}

Outros termos podem ser utilizados para representar as preferências do consumidor e a correspondência do produto e do serviço a essas preferências como pode ser visto com Geng et al. (2011).

\section{Nota 17}

A qualidade em serviços como fator de influencia na percepção do consumidor, conforme Parasuraman, Berry e Zeithaml (1988), pode ser agrupada em cinco dimensões. Os (i) "aspectos tangíveis" referentes às condições dos canais de serviços, infraestrutura e recursos necessários. A (ii) "confiabilidade" relacionada confiança e exatidão na prestação, ou seja, serviços realizados no prazo e corretamente. A (iii) "responsividade" que corresponde ao fornecimento do serviço prontamente e, também, à disposição em auxiliar os clientes. A (vi) "segurança" que engloba o conhecimento necessário para a execução dos serviços (competências), cortesia, respeito e comunicação efetiva. E a (v) "empatia" que corresponde a demonstrar atenção e interesse ao consumidor de forma personalizada. A empatia engloba a acessibilidade, sensibilidade e esforço no atendimento das necessidades.

\section{Nota 18}

A descrição detalhada e completa da estrutura de gestão de estoques pode ser obtida com Sterman (2000). 


\section{Nota 19}

Detalhes adicionais referentes à estruturação desta consideração do sistema produtivo em uma abordagem didática e detalhada podem ser obtidos com Sterman (2000).

\section{Nota 20}

Essa representação por uma demanda de referência e a consideração do objetivo desse sistema como sendo a entrega de "pacotes de valor" pode gerar uma interpretação ambígua frente a um dos objetivos fundamentais considerado ao PSS, o menor impacto ambiental frente às estratégias convencionais. Contudo, salienta-se que a redução dos impactos ambientais se deve a uma série de questões abordadas ao longo de todo o desenvolvimento do contexto e dos elementos do PSS e estimada ou mensurada por ferramentas específicas. Essa representação genérica explora unicamente os reflexos dinâmicos da associação de serviços ao produto em um contexto definido.

\section{Nota 21}

Essa descrição está conforme a consideração de Kotler (1998) que indica a satisfação como uma função da percepção e das expectativas e também é utilizada na descrição sistêmica por Kazemi, Eshlaghy e Tavasoli (2011). Na descrição referente a esta análise a qualidade percebida já estaria ajustada pelo preço relativo para a composição da percepção do valor.

Nota 22

As taxas de saída e desistência inserem as falhas de desempenho do sistema pelo modelo proposto a exemplo do modelamento conduzido por Bianchi et al. (2009).

\section{Nota 23}

As defasagens (também chamados atrasos ou delays) são uma característica presente em todos os sistemas e caracterizam o seu comportamento. Essas defasagens atuam nos componentes de informação/ação /consequência. Determina o quão bem a informação e as ações estão ajustadas influenciando diretamente no comportamento do sistema.

\section{Nota 24}

Uma vez que a Dinâmica de Sistemas foca no comportamento dos sistemas e sendo este comportamento resultante de sua estrutura, a utilização de estruturas genéricas para diferentes análises é muito empregada nos diagramas de fluxos e estoques. 0 emprego da estrutura genérica de gestão de estoques em pesquisas aplicadas ao sistema produtivo pode ser visto com: Zhang e Dilts (2004) e Zhai (2004) que analisam reflexos da rede de suprimentos na produção, e também com Lai, Lee e Ip (2003) que analisa o sistema produtivo com a aplicação do JIT.

Nota 25

Conforme a modelagem dinâmica de Kazemi, Eshlaghy e Tavasoli (2011).

Nota 26

Conforme o trabalho de Abramovici, Bellalouna e Göbel (2010) constante do portfólio bibliográfico de referência à análise e também o trabalho de Abramovici et al. (2009).

Nota 27

O sistema é trabalhado em diferentes níveis. No primeiro nível como um elemento da qualidade percebida pelo consumidor e potencialmente de redução dos impactos ambientais pela caracterização dos materiais empregados e demais parâmetros de desenvolvimento da embalagem. Em um segundo nível como facilitador da armazenagem nos pontos de distribuição e, em um terceiro nível, como facilitador ou viabilizador o transporte do conjunto. 


\section{Nota 28}

Fundamentos e exemplos dessas abordagens podem ser obtidos na literatura especializada como, por exemplo, com Khan (2008). 